King Edwin of Northumbria 'cared so much for the good of the people that, in various places where he had noticed clear springs near the highway, he caused stakes to be set up and bronze drinking cups to be hung on them for the refreshment of travellers' Bede 11.16

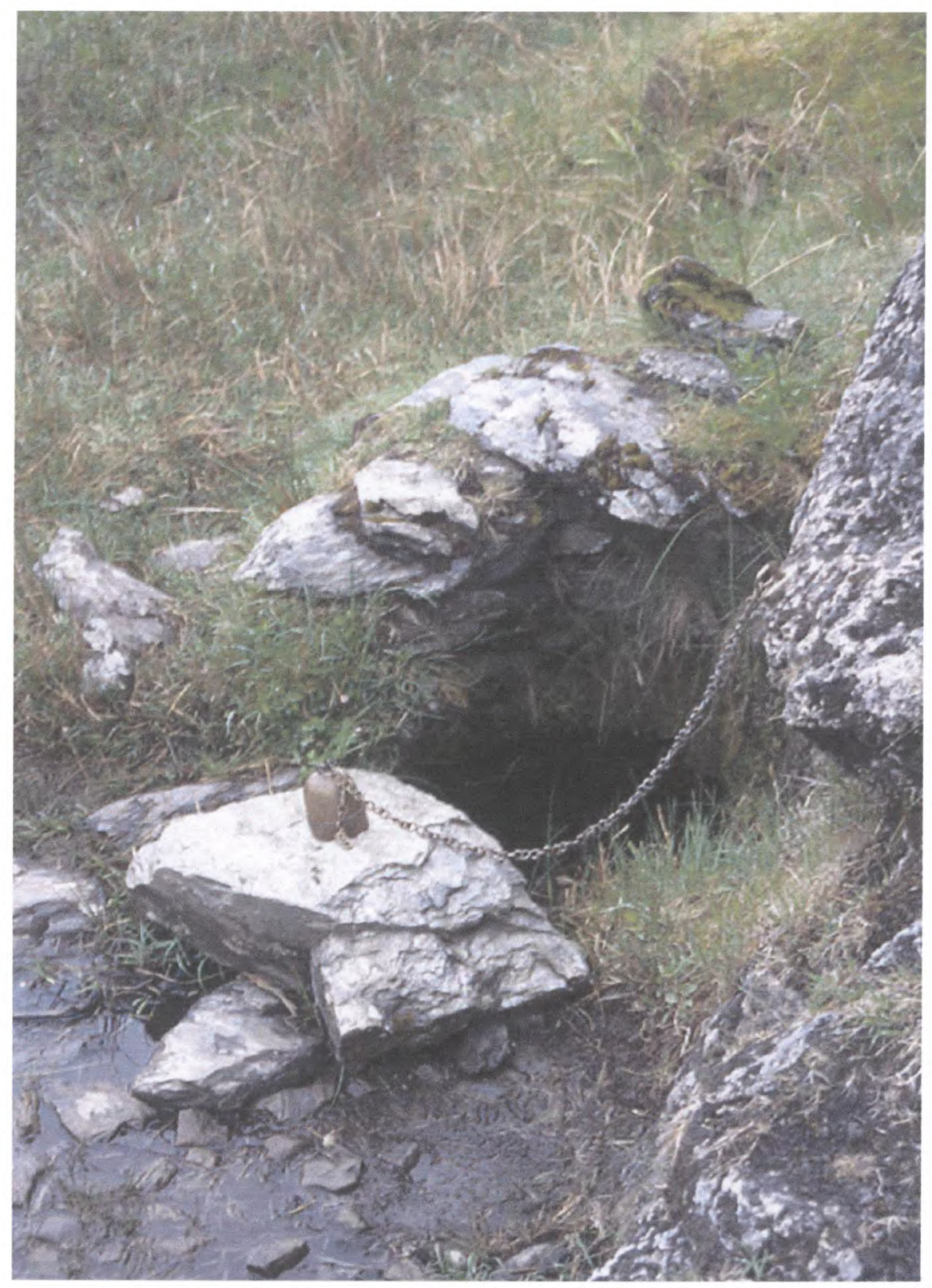

Drinking cup beside a mountain track, Colonsay. 


\title{
THE PLACE-NAME EVIDENCE FOR A ROUTEWAY NETWORK IN EARLY MEDIEVAL ENGLAND
}

(IN TWO VOLUMES)

\author{
BY \\ ANN COLE
}

VOLUME I

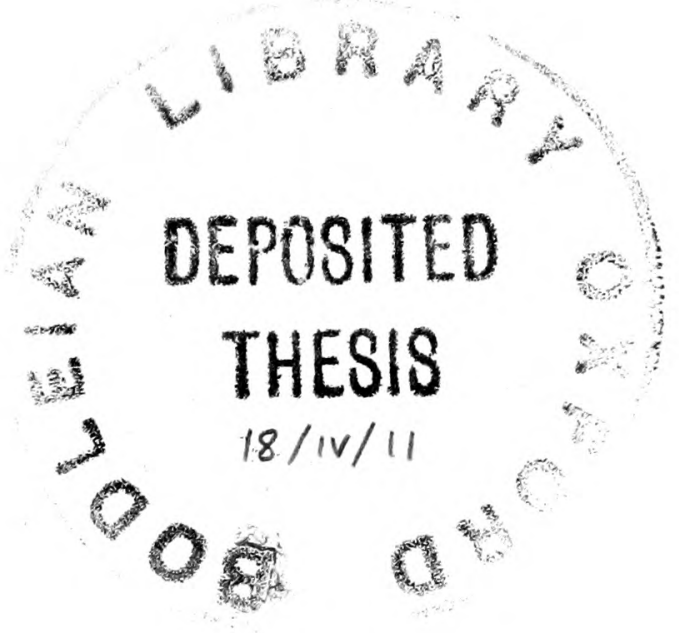

KELLOGG COLLEGE

UNIVERSITY OF OXFORD

2010 
In memory of A.t.G

Copyright by Ann Cole, 2010 


\section{CONTENTS}

\section{CONTENTS OF VOLUME I}

Acknowledgements iv

General abbreviations $\quad$ V

Note on County Boundaries and Abbreviations $\quad \mathrm{v}$

County Abbreviations and Place-Name Dictionary Bibliography $\quad$ v

Notes on Measurements and Terminology viii

Abstract $\quad$ xi

Chapter 1: Introduction: setting the scene 1

Chapter 2: Method 21

Chapter 3: Road Terms: ströt, weg, pceth, stïg, anstig, herepceth, heresträt 30

Chapter 4: Crossing Places: ford, vath, geläd, gewoed, faer, ritu, sarn, ferja, traiectus, brycg

Chapter 5: Facilities en route: mere, wielle, äewiell, äwielm, funta, strāet-tūn,

Coldharbour, caldecot, , mōr-tūn, drceg-cot, draeg-tūn, windlesōra, grāefe-tūn. 53

Chapter 6: Water transport: port, hȳth, stceth, stọth, lād, èa-tūn 75

Chapter 7: Other Place-Names associated with Routes: ceaster, wìc-hām, cumb-tūn, denu-tün, netel, nata.

Chapter 8: Place-Names used as Landmarks on Route-ways: öra, ofer, yfre, Overton, Orton

Chapter 9: Synthesis

Chapter 10: Further Considerations: chronology and supporting evidence

Chapter 11: Conclusion

Bibliography

\section{CONTENTS OF VOLUME 2}

Full list of Contents

Section 1: Measuring Proximity to Roman Roads and Ancient Tracks 1

Section 2: Lists, Maps, Graphs, Sketches and Photographs 9

$\begin{array}{ll}\text { Section 3: Details of Individual Places } & 179\end{array}$

End pocket: Map: The Early Medieval Routeway Network 


\section{ACKNOWLEDGEMENTS}

I acknowledge with gratitude the help given by many people, but especially by Margaret Gelling, who first kindled my interest in place-names; John Blair, my supervisor, for sound advice and guidance; Nigel James of the Bodleian map room, who, with patience and skill, enabled me to produce the colourful, concluding map, and Nancy Lowe, who suggested how it might all be made more comprehensible to the non-specialist. 


\section{GENERAL ABBREVIATIONS}

$\begin{array}{ll}\text { ASC } & \text { Anglo-Saxon Chronicle } \\ \text { AT } & \text { Ancient track as shown on O.S. Map of Roman Britain (used mainly } \\ & \text { in appendices) } \\ \text { BAR } & \text { British Archaeological Reports } \\ \text { DB } & \text { Domesday Book } \\ \text { EPNS } & \text { English Place-Name Society } \\ \text { GR } & \text { Grid reference } \\ \text { JEPNS } & \text { Journal of the English Place-Name Society } \\ \text { M } & \text { Roman road number as allocated by I.D. Margary } \\ \text { OE } & \text { Old English } \\ \text { OFr } & \text { Old French } \\ \text { ON } & \text { Old Norse } \\ \text { PN } & \text { Place-name } \\ \text { R Rd } & \text { Roman Road (used mainly in appendices) } \\ \text { S } & \text { Sawyer number } \\ \text { VCH } & \text { Victoria County History } \\ \text { NOTE ON COUNTY BOUNDARIES AND COUNTY ABBREVIATIONS }\end{array}$

The counties used are those existing at the time of the 1974 reorganisation, since the English Place-Name Society volumes and Ekwall's Concise Oxford Dictionary of English Place-names are based on those counties, as are many other historical works such as the Victoria County History volumes.

The abbreviations used are those employed in The Landscape of Place-Names as there is much less room for ambiguity among these than there is in the EPNS system. They are listed under the Place-Name Bibliography below.

\section{COUNTY ABBREVIATIONS AND PLACE-NAME DICTIONARY BIBLIOGRAPHY}

\section{County Abbreviations, and EPNS County Volumes, if any.}

BDF: The Place-Names of Bedfordshire and Huntingdonshire, A. Mawer and F.M. Stenton, 1926

BRK: The Place-Names of Berkshire, 3 vols, Margaret Gelling, 1973-6.

BUC: The Place-Names of Buckinghamshire, A. Mawer and F.M. Stenton, 1925.

CAM: The Place-Names of Cambridgeshire, P.H. Reaney, 1943. 
CHE: The Place-Names of Cheshire, 7 vols, J. McN. Dodgson, 1970-97.

CNW: Cornish Place-Name Elements, O.J. Padel, 1985.

CMB: The Place-Names of Cumberland, 3 vols, A.M. Armstrong, A. Mawer, F.M. Stenton and Bruce Dickens, 1950-2.

DOR: The Place-Names of Dorset, 3 vols, and in progress, A.D. Mills, $1977-$

DBY: The Place-names of Derbyshire, 3 vols, K. Cameron, 1959.

ESX: The Place-Names of Essex, P.H. Reaney, 1935.

GLO: The Place-Names of Gloucestershire, 4 vols, A.H. Smith, 1964-5.

GTL: Greater London

HMP: Hampshire

HNT: The Place-Names of Bedfordshire and Huntingdonshire, A. Mawer, and F.M. Stenton, 1926.

HRE: Herefordshire

HRT: The Place-Names of Hertfordshire, J.E.B. Gover, Allen Mawer and F.M. Stenton, 1932.

IOW: Isle of Wight

KNT: Kent

LEI: The Place-Names of Leicestershire, 4 vols, in progress, Barrie Cox, 1998-

LIN: $\quad$ The Place-Names of Lincolnshire, 6 vols, in progress, Kenneth Cameron, 1985 -

LNC: Lancashire

MDX: The Place-Names of Middlesex, J.E.B. Gover, Allen Mawer and F.M. Stenton, 1942.

MON: Monmouthshire.

NFK: The Place-Names of Norfolk, 3 vols, in progress, Karl Inge Sandred, 1989-

NTB: Northumberland

NTP: The Place-Names of Northamptonshire, J.E.B. Gover, Allen Mawer and F.M. Stenton, 1932.

NTT: The Place-Names of Nottinghamshire, J.E.B. Gover, Allen Mawer and F.M. Stenton, 1940.

OXF: The Place-Names of Oxfordshire, 2 vols, Margaret Gelling, 1953-4.

RAD Radnorshire.

RUT The Place-Names of Rutland, Barrie Cox, 1994.

SFK: Suffolk.

SHR: The Place-Names of Shropshire, 5 vols, in progress, Margaret Gelling, 1990-

SOM: Somerset. 
SSX: The Place-Names of Sussex, 2 vols, A. Mawer and F.M. Stenton with J.E.B. Gover, 1929-30.

STF: The Place-Names of Staffordshire, 1st vol. only, J.P. Oakden, 1984.

SUR: The Place-Names of Surrey, J.E.B. Gover, A. Mawer, and F.M. Stenton, 1934.

WAR: The Place-Names of Warwickshire, J.E.B. Gover, Allen Mawer and F.M. Stenton, 1936.

WLT: The Place-Names of Wiltshire, J.E.B. Gover, Allen Mawer and F.M. Stenton, 1939.

WML: The Place-Names of Westmorland, 2 vols, A.H. Smith, 1966-7.

WOR: The Place-Names of Worcestershire, A. Mawer, F.M. Stenton and F.T.S. Houghton, 1927.

YER: The Place-Names of the East Riding of Yorkshire and York, A.H. Smith, 1937.

YNR: The Place-Names of the North Riding of Yorkshire, A.H. Smith, 1928.

YWR: The Place-Names of the West Riding of Yorkshire, 8 vols, A.H. Smith, 1961-3.

County abbreviations and author's initial(s) for EPNS Popular Series and non-EPNS volumes, mainly used in the lists in Appendix, Section Two.

CNW: S. Saxon Place-Names in East Cornwall, Örjan Svensson (Lund, 1987).

DOR: M. Dorset Place-Names: their Origin and Meanings, A.D. Mills (Wimborne, 1986).

DOR: F. The Place-Names of Dorset, A. Fägersten (Uppsala,1933).

DUR: W. A Dictionary of County Durham Place-Names, Victor Watts (EPNS popular series 3, Nottingham, 2002).

HMP: C. The Place-Names of Hampshire, Richard Coates (London, 1989).

HMP: G. The Place-Names of Hampshire, J.E.B. Gover (unpublished typescript; a copy is held by EPNS in Nottingham, c. 1961).

HRE: B. The Place-Names of Herefordshire: their Origin and Development, A.T.

Bannister (Hereford, 1916).

HRE: CC. Herefordshire Place-Names, Bruce Copleston-Crow (BAR British Series 214, Oxford, 1989).

IOW: K. The Place-Names of the Isle of Wight, H. Kökeritz (Uppsala, 1940).

IOW: M. The Place-Names of the Isle of Wight, A.D. Mills (Stamford, 1996).

KNT: KPN. Kentish Place-Names, J.K. Wallenberg (Uppsala, 1931).

KNT: PNK. The Place-Names of Kent, J.K. Wallenberg (Uppsala, 1934).

LNC: E. The Place-Names of Lancashire, E. Ekwall (Manchester, 1922). 
LEI: C. A Dictionary of Leicestershire and Rutland Place-Names, Barrie Cox (EPNS Popular Series 5, Nottingham, 2005).

LIN: C. A Dictionary of Lincolnshire Place-Names, Kenneth Cameron (EPNS Popular Series 1, Nottingham, 1998).

NTB: B. Northumberland Place-Names, Stan Beckensall (Rothbury, 1992).

NTB: M. The Place-Names of Northumberland and Durham, A. Mawer (Cambridge, 1920).

STF: H. The Place-Names of Staffordshire, David Horovitz (Brewood, Stafford, 2005).

\section{$\underline{\text { Regional volumes }}$}

A Dictionary of Lake District Place-Names, Diana Whaley (EPNS Regional Series 1, Nottingham, 2006).

The Place-Names of the Deben Valley, W.G. Arnott (Ipswich, 1946).

\section{$\underline{\text { National volumes }}$}

DEPN: The Concise Oxford Dictionary of English Place-Names, Eilert Ekwall, $\left(4^{\text {th }} \mathrm{ed}\right.$. Oxford, 1960).

CDEPN: The Cambridge Dictionary of English Place-Names, Victor Watts (Cambridge, 2004).

FIELD: The Place-Names of Great Britain and Ireland, John Field (Newton Abbot/London, 1980).

MILLS: Dictionary of British Place-Names, A.D. Mills (Oxford, 2003).

\section{NOTE ON MEASUREMENTS AND TERMINOLOGY}

\section{LINEAR MEASUREMENTS}

The decision to use imperial units was not taken lightly since it was recognised that metric units are increasingly employed in academic writing. However, most people still think of road distances in terms of miles and are more comfortable with the idea that they have walked, say, 2 miles rather than 3.2 kilometres. Since a recurrent theme here is the distance between settlements it seemed reasonable to adhere to the familiar unit of the mile. When much shorter distances are involved it is recognised that many people prefer to work in metres. Fortunately an eighth of a mile, one furlong, is almost exactly 200 metres (actually 201.3) and so it has been practicable to put both scales on many of the graphs. 
Having decided to use miles it followed that heights should be expressed in feet above sea level, as it is bad practice to mix imperial and metric units. More recent Ordnance Survey maps do express heights in metres, but since much of this study was done using older maps, less complicated by new roads and recently built up areas, their use of feet fitted in very well.

When measuring the gradients of wegs (chapter 4) it was not really practicable to give heights in metres as well, and as the desired figure is a ratio this was not thought to matter very much. Even gradients expressed as a ratio, e.g. 1 in 5, are now giving way to percentages e.g. $20 \%$ on the most recent Landranger maps and on road signs.

$$
\begin{array}{ll}
1 \mathrm{mile}=1.6 \mathrm{~km} & 1 \mathrm{~km}=0.62 \text { miles } \\
1 \mathrm{ft}=0.3 \text { metres } & 1 \text { metre }=3.28 \mathrm{ft} \\
100 \mathrm{ft}=30.5 \text { metres } & 100 \text { metres }=328 \mathrm{ft}
\end{array}
$$

\section{MAJOR AND MINOR}

Some collective terms were needed to distinguish settlements that were either the centres of DB estates, ancient parishes or townships and likely to have been of greater importance, from those that are mostly first evidenced after DB, were not centres of ancient parishes or townships and are therefore likely to have been smaller and of lesser importance. The terms 'major' and 'minor' respectively were used for these categories as a useful shorthand to avoid endless repetition. It is recognised that 'importance' has not been defined (but in this context will include being more widely known to the population at large) and that a small number of settlements will be inappropriate to the categories in which they find themselves. The size and importance of any settlement varies over time, as economic and social conditions change; for instance, the tendency towards nucleation with the development of the open-field system towards the end of the early medieval period, mostly in the heart of England, or the rise and fall of mining settlements as resources are discovered or worked out, or the changing fortunes of ports as estuaries silt up or ships increase in size. In an effort to identify a hierarchy in early medieval times the distinctions described above have been used as a guide. 


\section{TERMS FOR ROADS}

Reference is so often made to the non-Roman roads shown on the O.S. Map of Roman Britain where they are described as 'prehistoric track-ways in contemporary use' that the phrase 'ancient track(s)' has been reserved for them, and the abbreviation 'AT' used in many of the figures. R.Rd. stands for Roman road. Any other early road is referred to as "old road, old route, old track' etc.

\section{ENGLAND}

England is used, except where otherwise stated, to mean the present-day geographical extent of the country. It is the area covered by the study, chosen largely because the sources of information such as the VCH and EPNS volumes are based on it, and because it is an easily recognised entity. England as an entity did not exist in the early Anglo-Saxon centuries. The area occupied by the Anglo-Saxons and speaking Old English varied from the earliest toe-holds in the south and east, to an area encompassing southern Scotland and reaching far into the South-West Peninsula in the later Anglo-Saxon period, so to use the term Anglo-Saxon England has little meaning without qualification. 


\section{ABSTRACT \\ THE PLACE-NAME EVIDENCE FOR A ROUTE-WAY NETWORK IN \\ EARLY MEDIEVAL ENGLAND \\ BY \\ ANN COLE \\ KELLOGG COLLEGE \\ UNIVERSITY OF OXFORD \\ SUBMITTED FOR THE DEGREE OF DOCTOR OF PHILOSOPHY \\ TRINITY TERM 2010}

Evidence for routes in use in the early medieval period from documents and excavations is fragmentary, and from maps is nil, but place-names help to fill the gap. Known early roads, travellers and possible origins of place-names are considered before detailed examination of the place-names that consistently occur by routeways. Ways of measuring proximity of named settlements to routeways, including the chi-squared test and dispersion graphs, are described.

The place-names are considered in detail. The road terms strēet and weg yielded useful information; paeth and stīg did not. Gewced and gelād indicated difficult crossings; ford was too ubiquitous to be useful. Facilities available were indicated by mere-tūn and byden-welle (water supply); strēet-tūn and calde-cot but not Coldharbour (lodgings); mōr-tūn and mersctūn (fodder); drag-tūn and drceg-cot (aid to travellers in difficulty); grāefe-tūn (pay-load). Ora and ofer, round-shouldered ridges, were used as 'signposts' at significant points on roads and waterways to indicate, inter alia, harbour entrances, cross roads and mineral deposits. Cumb-tūn, denu-tūn, ceaster and wìc-hām were easily recognised and helped travellers to identify their whereabouts. Seaways and rivers in use were highlighted by the use of port, hȳth, èa-tün and lād.

A series of these indicative names occurring along a route, usually Roman, suggests that the route was in use. Certain saltways, Gough (c.1360) and Ogilby (1675) routes and a few others were also highlighted. Findings are summarised on the end-paper map.

As a check on the results, coin-find distributions for the early eighth century and late tenth/ early eleventh century were mapped against route-ways. Routes in use from placename and coin evidence were broadly similar. Evidence from pottery scatters was difficult to assemble, and gave poorer results. The evolution of the naming system is discussed.

The consistent way that widely occurring landforms and habitation types were named throughout England enables the mapping of an early medieval routeway network using place-name evidence. The appendices list and map each corpus. 


\title{
THE PLACE-NAME EVIDENCE FOR A ROUTEWAY NETWORK IN EARLY MEDIEVAL ENGLAND
}

\author{
BY \\ ANN COLE \\ KELLOGG COLLEGE \\ UNIVERSITY OF OXFORD \\ D.PHIL. THESIS, 2010
}

There is little evidence to indicate which important routeways were in use in medieval England during the period between the end of Roman rule in the early fifth century and the advent of the earliest maps (the Matthew Paris map of c.1250 and the Gough map of c.1360), and of the more detailed records which survive after the Norman Conquest. This thesis examines the hypothesis that place-names, in particular settlement names, might be used to fill this gap. Names evidenced by 1086 are the most valuable, but those evidenced between 1086 and about 1500 are also considered. The evidence from charter boundaries, although containing many references to roads and crossing places, was not used: the distribution of surviving charters is patchy so one could not deduce a national network from the material; moreover, the many references to minor tracks would not be relevant.

If there are certain corpora of place-names that regularly occur close to the roads that are known to have existed (at least as landscape features - in practice mostly Roman roads) and rarely occur elsewhere, it is suggested that they may indicate which routes were regularly in use by long distance travellers (i.e. people whose journeys took more than one day); their needs, in terms of information about the routes and the facilities available beside them. would have been different from the needs of those using the roads for their daily activities or to go to the local market.

As a way of measuring whether the distribution was random or correlated well with old roads the chi-squared test was described and applied to a variety of corpora. The old roads were taken to be those shown on the O.S. Map of Roman Britain $\left(4^{\text {th }} \mathrm{ed}\right.$.), and the distance between the oldest part of the settlement (taken to be the church, manor house or cross roads) and the road was used. A test run using strāet-tün showed that even if there had been settlement drift over the centuries and even if the church did not exactly represent the heart of the settlement at the time of naming, the correlation was remarkably close. As this was so with strät-tūn (widely accepted to mean 'settlement on or by a Roman road') it was thought likely that the same thing would apply to other corpora.

The scene was set by considering who might be travelling long distances, what roads and tracks might already have existed at the start of the early medieval period, what means of travel were available, how fast one could travel and the size of the load that could be carried. Some consideration of the facilities that a traveller might need (food, water, etc.) and the possible effects of the laws governing the use of the highway on travel was given.

Since this study is based on place-name evidence, some discussion of the origins of the names is included, including their stability and longevity or otherwise; who might have coined them - whether local people, people in authority or the road users themselves.

The scene was then set to examine the terms describing the routeways themselves, followed by an examination of some other place-name corpora having a close correlation with routes to see if they might be relevant to travellers' needs. A separate chapter dealt with place-names that were related to water transport. The results are noted below.

Chapter 3 discussed place-names referring to routeways. Strāt meant 'paved road'. In the

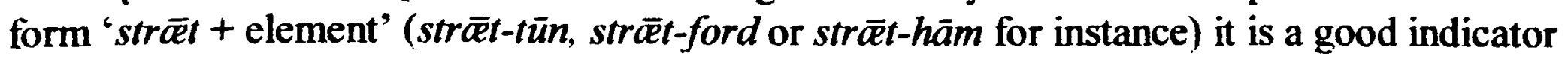


of a Roman road. but strēet uncombined needs to be evidenced by DB. Weg ('way') was used almost invariably of non-Roman roads. It was applied to local tracks from a village to its outlying fields and woods, to long-distance tracks such as the Great Ridgeway and the Icknield Way, and to settlement names. Investigation into the settlement sites showed that weg usually referred to a steep track, especially in cases evidenced by DB or which were parishes (i.e. 'important' places). To use wheeled vehicles on such steep gradients would have been dangerous; the name acted as a warning to carters. Path (path) and stig (upland track) referred to tracks too insignificant to be part of a national routeway network.

In chapter 4 the crossing-place terms were examined. Ford was a very common term referring to crossings of all sizes and degrees of importance: it was of little use in picking out major routeways . Vath, the ON equivalent, was restricted in use to the northern counties and also referred to a variety of different, mostly unimportant, crossings, and so was of little use. Geläd and gewoed, referring to difficult crossings (liable to floods or involving tidal water), were helpful but sometimes described alternative routes which could only be used in favourable conditions. Brycg ('bridge, causeway, bridge with causeway') had to be used with care as many brycg names which referred to minor, local crossings of small water-courses were probably not on major routes. Where a brycg name was recorded in DB and crossed a substantial river its building would have involved a considerable investment of material and labour, so was likely to be on a well-used route. Ferja (ferry) was uncommon but clearly important, especially at Ferriby, the Humber crossing.

Chapter 5 describes the facilities of use to the traveller. Water was essential on long journeys for man and beast, so knowing where it was available would be important. There were various sources: mere means 'pond' or 'lake'; a sub-set of mere - the mere-tüns, 'settlement benefiting from a pond or lake', are frequently man-made and by routeways, although a few refer to natural meres. The traveller would understand from the name that water was available there. There are some vitally important examples of 'element + mere' (e.g. Ashmore, Imber) in the chalk downlands which travellers would be aware of. Although welle, 'spring', was not normally related to routeways, a sub-set, the byden-welles, 'spring with a collecting vessel' was; they were usually by poor springs where the water could accumulate slowly in a trough. Ewiell and $\bar{a} w i e l m$ (Ewell, Ewelme) refer to copious springs, and for hydrological reasons often occur at the foot of escarpments. Both the crests and feet of these escarpments make good routeways (e.g. the various 'ridgeways') so there is a link between these springs and the routeway network. Most travellers would have been glad of food and shelter especially in inclement weather; it may have been provided at the strōt-tīns - their fairly regular spacing along the Fosse Way was noted. The belief that Coldharbour was a poor shelter beside a Roman road was questioned because prior to 1600 occurrences of the name were very rare. It is apparently associated with Roman roads only because those roads were in use in the seventeenth and later centuries when the name Coldharbour was most often bestowed. Calde-cot means 'cold shelter' or 'cold cottage'. Calde-cots (Caldecote, Caulcot etc.) occur in cold, damp, exposed situations, and were likely to be struggling to survive; many are by routeways and the benefit from passing traffic may have been just sufficient to ensure survival. Travellers sometimes face difficulties on their journeys, such as flooded rivers, particularly muddy roads or long, steep hills; the droeg-tūns and drag-cots (Drayton. Draycot), are found in these situations. Droeg is thought to mean 'place where things are dragged', so it seems probable that the inhabitants of a Drayton or Draycot had some means of assisting travellers in difficulty such as a ferry over a flooded river or extra draught animals for steep hills perhaps. People travelling with animals, such as drovers and jaggers, would need grazing for their stock. If this was in short supply, for instance in winter, they might need to purchase fodder. Heg and filithe were the two terms meaning 'hay'; neither correlate closely with routeways. Mōr-tün and mersc-tūn (Mor(e)ton, 
Marston) occur where soil conditions are such that the land is best kept under permanent grass, as pasture or hay meadow. It has been suggested that the mōr-tüns were responsible for gathering in the hay for the estate in which they lay, but as many have good access to roads and rivers they could provide fodder for travellers' animals or to take to a nearby town for sale. Some of the gräf-tüns (Grafton) 'settlement connected with coppiced woodland' are on salt-ways leading to Droitwich and may have provided a return load for salt-traders; coppiced wood was burnt in large quantities to evaporate the brine.

Chapter 6 concerns water transport. Port', a borrowing from Latin, is sparingly used of early, important havens along the south coast and Bristol Channel; some had been used by the Romans, others are referred to in the Anglo-Saxon Chronicle. Hyth is used of landing places in sheltered inlets along the south and east coasts. It is also used of river ports. Many, such as Lambeth. Chelsea and Putney, occur on the Thames in London, and the series extends just beyond Oxford. The Trent has several examples; they occur occasionally on other rivers. After the Conquest increasing numbers appear in the Fens reflecting the difficulty of overland travel in the marshes, and the activities of the religious houses in draining and utilising the area. OE stceth and ON st $Q$ th (staithe) are difficult to distinguish from ON stathr, but the ON form occurs in north-west England and is connected with the Viking activities in the Irish Sea. Because coastal landforms change comparatively rapidly, it has been necessary to describe, as far as possible, the earlier geomorphology of the sites of the ports, hyths, stoeths and st $q$ ths to understand just why they were located in particular places. The presence of $\bar{e} a-t \bar{u} n s$ (Eaton, 'river settlement') mainly on the upper reaches of rivers suggests that their inhabitants were responsible for keeping open the local stretch of river. Examples occur on the upper reaches of the Thames, Severn, Wye and their tributaries.

'Other Place-Names', the subject of chapter 7, while not describing the route or its facilities, were useful landmarks for travellers who would recognise that they had arrived at a -ceaster (-chester, -caster, a term normally describing a Roman settlement) by the ruins of stone buildings, and that a place called wic-häm (Wickham etc.), they would be close to an old Roman settlement. At a cumb-tün (Compton) there would be a characteristically bowlshaped valley with the settlement nestling at the bottom of it.

The terms or $a$ and ofer (and to a lesser extent $y$ fre) probably served as the early medieval equivalent of a signpost. They refer to hills having a flat top with a rounded shoulder at one or both ends. Ora, a borrowing from Latin ora 'shore', was the term used in southern England while ofer, an Old English word, was the midland and northern equivalent. Oras occurred at the entrances to ports where they would be the first landforms seen by sailors seeking the harbour entrance and helped them to identify their position. Inland $\overline{o r} a$ and ofer often marked road junctions, river crossings and ways leading to mineral resources, such as Droitwich salt and Peak District lead.

Place-names indicative of important routeways were plotted on a map showing Roman roads and certain prehistoric tracks to which salt-ways, and a selection of Gough (c.1360) and Ogilby routes were added if they had indicative place-names beside them (Ogilby's road atlas was published in 1675). Then, assuming a good day's journey was 20 miles, a stretch of road 10 miles either side of each indicative place-name was highlighted as likely to have been in use. Names evidenced by DB indicate routes in use in the early medieval period. Those names first evidenced between DB and 1500 (although possibly coined earlier) indicated routes that had come into use by early post-Conquest times. This produced a series of long stretches of Roman roads apparently in use, together with the Icknield Way, the Great Ridgeway, and some other routes; together they make up a useful network integrating fairly well with the waterway network. It also highlighted a number of routes apparently not in use. Many routes radiated from London: the more easterly Roman road to the Norwich area was used in preference to the one through Ixworth. A route, partly Roman, partly Great North 
Road. from London ran east of the Pennines to the Scottish border. The trans-Pennine routes followed the courses of the Roman roads to Carlisle. the Ribble estuary and Manchester. but north-west England generally was poorly served. Roman roads leading west from London were supplemented by three Gough routes. Evidence for the use of Watling Street (London to Wroxeter) and for the northern part of the Fosse Way (High Cross to Lincoln) is patchy. The Icknield Way, Great Ridgeway and the Pilgrim's Way seem to have been well used, but the Harroway from the Hog's Back to near Shaftesbury has no sign of use. The areas best served by the road network were Mercia and Wessex.

By examining the dates at which various categories of place-names were first evidenced it was possible to discern some development in the naming of settlements from the early ones describing natural features to later ones (from the mid-ninth century) describing functional tüns. 'Functional-tün' is the term describing settlements which had some resource or duty beyond the normal agricultural ones. Examples mentioned here include strāet-tūn, mere-tūn, draeg-tūn, mōr-tūn, gräf-tūn. The six early medieval centuries saw many changes; bridgebuilding, and changes in trading patterns, especially due to Viking activities, sometimes changed the relative importance of routes. Other changes: the development of mineral resources; the advent of Christianity and activities of the monasteries; the growth of towns; increasing administrative activities and the needs of defence also had some effect, but overall the impression is of stability and continuity in the routeway network.

As possible ways of substantiating these results, the distribution of coin and pottery finds was investigated. Find spots of single coins were plotted on the roads map, but data from the Fitzwilliam Corpus of Early Medieval Coin Finds only gives the four-figure grid reference of the nearest settlement, so it was not possible to tell if the find was made close to the road or a mile or two from it. The finds are also largely restricted to southern and eastern England. Even so there seemed to be a reasonably good correspondence between roads in use as suggested by the place-name evidence and those in use as suggested by the coin evidence. Data concerning the find spots of sherds of distinctive pottery, such as Ipswich. Stamford and Lincoln ware, were hard to find and incomplete. Beyond suggesting that pottery was probably moved by water where possible, it was not helpful in confirming the routes in use in early medieval times.

The results of the study are summed up in a final, large, coloured map of the Routeway Network of Early Medieval England, showing the place-names mentioned and indicating which of the different routes were in use.

An appendix in three sections gives the data upon which the study rests.

Section 1 describes the method used to apply the chi-squared test and gives some of the results.

Section 2 consists of lists of the examples of each place-name type giving the county, grid reference, an early spelling, the date of first mention and a reference. Gradients are given for $s t r \bar{x} t$, weg and poeth; soil types for mör-tüns and mersc-tüns. Each place-name corpus is mapped; a few are illustrated with sketches or photographs.

Section 3 describes in detail the situations of many places with respect to routes namely the examples of weg, stig, paeth, gelād, gewoed, faer, ritu, Sarre, Traiectus, ferja, draeg-tūn, draeg-cot, port, hÿth, stath, stQth, ea-tün, öra, ofer, yfre, Orton and Overton. 


\section{CHAPTER 1}

INTRODUCTION: SETTING THE SCENE

\section{AIM, SOURCES AND METHODS}

The aim of this research is to see if it is possible to identify the major routes that were used by long-distance travellers both by land and water in England ${ }^{1}$ during the early medieval period through a study of place-names, and to see if the result of such a study produces the basic framework of a countrywide communications network. It is not the intention to include minor local tracks within estates or between adjoining settlements for reasons described below.

The primary sources of evidence used in this study are the place-names that describe land and water routes or features useful to travellers and which occur consistently beside those routes. This would not preclude the usefulness of such names in informing the more stay at home population. The existence of such routes can be checked against finds of coins of the period, while later evidence from the earliest maps, the itineraries of kings and the medieval laws relating to public works such as road or bridge maintenance may confirm older routes which remained in use or indicate newer routes which had developed as conditions changed.

There are many reasons for concentrating on place-name evidence as an indicator of major routes in a countrywide setting. Firstly, specialist dictionaries by Ekwall, Mills and Watts exist to interpret place-names all over England in some measure, while the volumes of the English Place-Name Society cover many counties wholly or partly and in greater or lesser detail. Secondly, examples of any place-name terms which might prove useful in identifying routeways are widely dispersed across England. It is not until each corpus is assembled and mapped that it becomes apparent whether that corpus is related to routeways or not. It would not be possible to deduce this if the study was restricted to a smaller region such as East Anglia or Wessex (for instance, names like cumb-tūn might escape detection altogether as they are so regional in distribution). Thirdly, even when using only the place-names and not the charter boundary names, there is a large number to investigate: the detailed notes about many of them occupy a second volume.

The study of the place-names has involved fieldwork spread over 20 years or more. Sometimes it was necessary to retrieve the OE meaning of the word, e.g. geläd, before it could be used to illuminate its significance to travellers. In other cases it was necessary to shed light on local situations where it was not clear from maps alone just what the name referred to. For instance, it was not possible to tell from a map that the 'ford' of Orford SFK, was a causeway from the settlement to the haven (see vol. 2, pp.218). Therefore, fieldwork was an important component of the study in places as far apart as Yarnspeth on the Scottish Borders to Chivenor in north-west Devon and Cattawade in Suffolk. Sometimes it involved waiting for high or low tide, and at other times seizing the opportunity of severe flooding to examine river crossings, especially the gelāds by the Thames and Severn.

The Anglo-Saxon charter boundaries contain a wealth of material relating to the landscape and the routes which criss-cross it. For the most part they have not been used in this study for a variety of reasons. Firstly, there is an incomplete coverage of England: in particular, the northern counties and East Anglia have few charters, and one could not construct a national routeway network from this evidence alone. Secondly, even where charter boundaries are numerous they are rarely contiguous so that any one route cannot be traced very far. Thirdly,

\footnotetext{
${ }^{1}$ See p. $x$ for a definition of 'England'

${ }^{2}$ For a list of all such books and abbreviations see pp. v-viii. For other abbreviations see $\mathrm{p}$. $v$.
} 
many of the tracks mentioned are too small and local to be part of a national network. Fourthly, the bounds of some charters have not been solved. Fifthly, some of the place-names found to be useful to travellers are not used as boundary marks although they may occur as names of estates, and lastly, to include the mass of names occurring in charter boundaries with an already large corpus of place-name material would be more than could worked through in a study of this nature.

However, charter boundary material can be useful. In fact some has been incorporated inadvertently where place-name volumes have given a charter boundary spelling of a feature, or more often of an estate, whose name has survived into more recent centuries. Examples are Lomer HMP, (S 693) and Temple Grafton WAR, (S 1214). Once the framework of the early medieval routeway system has been deduced, the charter boundary material could be very helpful in filling in the network of minor roads between the main routes, as Della Hooke has done in her study of the Hwicce. ${ }^{3}$ It could also confirm short stretches of major routes. In fact, a few elements used in charter boundaries are sufficiently important for elucidating the routeway network for them to be mentioned here occasionally on the grounds that it would be perverse to exclude a useful piece of evidence because its name has failed to come down to us today. Herepceth and herestrat (used without the addition of another element, usually ford) give rise to few settlement names, just three of each (see list: fig. 3.18), but they describe important roads. Where a track under discussion is known to have been called a herepceth or herestraet in a charter it can be helpful to mention that fact, but the charter boundaries have not been studied systematically to extract these two terms.

A second exception has been made in the case of $\bar{r}$ ra. As this element seems to be so important in indicating particularly early routes and approaches to havens it was thought useful to include the charter boundary examples too. In fact they are quite a small proportion of the whole.

If a study of place-names can identify the main routes in use in early medieval England there would be scope for local studies by people with local expertise to fill in the gaps between the main routes with a network of local tracks. They might make use of the relevant terms identified here or material from charter boundaries, documentary sources, old maps, field work or any other clues. In essence this study provides a framework for other studies to link into, as exemplified by Hooke. ${ }^{4}$

If an England-wide communications network can be deduced from a study of place-names one would expect it to have linked places which needed good road or waterway connections. These might be trading centres like London, Ipswich or Hamwic (Southampton) or ports where ships carrying goods and passengers might berth. The products of mines and quarries would need to be moved to where they were to be processed (if need be) or used; deposits of iron ore, or iron itself, from the Weald, lead from the Peak District or Shropshire, salt from Droitwich and the Cheshire wiches would all need to be accessed by routeways. Important royal centres used by itinerant kings would need to be accessible - perhaps too, the less long-lasting centres of Tamworth, Rendlesham and Yeavering/Milfield might be served by important routes. Ecclesiastical centres, both sees like Canterbury, York and Worcester, and centres of pilgrimage like St Albans might also be linked into the major routeway network. A good correlation between these kinds of destinations and the main routes would help to confirm that the routes were part of an important network.

To pursue this study, the results obtained by place-name scholars in tracing back and interpreting English settlement-names must be applied to the study of old routeways in the expectation of identifying those which were in use in the early medieval period. The work also

\footnotetext{
${ }^{3}$ Della Hooke, The Anglo-Saxon Landscape: The Kingdom of the Hwicce (Manchester, 1985), p. 121, fig. 30.

${ }^{4}$ Hooke, Anglo-Saxon, p. 121, fig. 30.
} 
involves an interdisciplinary approach in that one must be aware of not only the philological aspects but also the geographical, geological and historical aspects. Regarding the geographical, the size and distribution of the population and settlements, resources (whether food, wood or minerals), the nature of the routeways used to distribute them, the underlying geology affecting road surfaces and farming methods, the hydrology in understanding riverflow and flood-risk, and geomorphology in tracing coastal changes must all considered. On the historical side some understanding of the know-how available for farming, cart-building, boatbuilding, bridge-building and metal-working, the political set-up - whether power was unified or fragmented into several 'kingdoms', the economic means of exchange, market sites, and regulations concerning markets and road-users is needed. Archaeology also has its part to play in noting coin and pottery finds and types, in discovering the abutments of old bridges or the alignment of Roman roads. When it comes to fieldwork it is valuable to travel the old roads to see the landforms as the Anglo-Saxons saw them - to know if it is possible to see A from B and thus use it as a landmark to confirm one really is on the right road; to experience the long hills, the muddy tracks and the welcome springs, to note the plants by the wayside that may be useful fodder or those which can indicate the soil types and inform the traveller much about the conditions underfoot and the farming possibilities of the neighbourhood. The fieldwork needs to be done personally, but for other aspects of the study one has to draw on the earlier work of the place-name and routeway specialists, and of map-makers.

There have been numerous books and articles about English roads, tracks and waterways. They vary from detailed studies of one period, such as Margary's and Davies' work on Roman roads, ${ }^{5}$ to chronologically based studies of routes, such as Christopher Taylor's Roads and Tracks of Britain ${ }^{6}$ and B. P. Hindle's Roads and Tracks for Historians. ${ }^{7}$ There are books on special groups of road-users, such as The Drovers by Shirley Toulson, ${ }^{8}$ and about particular regions, such as Arthur Raistrick's Green Roads in the Mid-Pennines, ${ }^{9}$ there are works on bridges such as Harrison's The Bridges of Medieval England,$^{10}$ on waterways such as John Blair's Waterways and Canal-Building in Medieval England. ${ }^{11}$ There are brief accounts of individual routes, such as the Bedford Way. ${ }^{12}$ Place-name scholars, notably Ekwall, ${ }^{13}$ the editors of the EPNS volumes and most recently Victor Watts, ${ }^{14}$ have spent over 80 years collecting spellings and deducing the meaning of English place-names. There is now a good coverage of most English counties, and, even for those not covered fully by the EPNS survey, the main places are covered by Ekwall, Mills ${ }^{15}$ and Watts. This enables the non-philologist to use the results of their labours in historical and geographical studies. The charter-boundary material has been used by G.B. Grundy in a series of articles in the Archaeological Journal to identify roads and tracks in Berkshire, Hampshire, Wiltshire, Somerset, Devon, Worcestershire and the Severn Valley ${ }^{16}$ and by Della Hooke in detailed local studies of the landscape and land-use for example in The Anglo-Saxon Landscape: The Kingdom of the Hwicce. ${ }^{7}$ Margaret

\footnotetext{
${ }^{5}$ I.D. Margary, Roman Roads in Britain (London, 1955-7; revised edition, 1973); Hugh Davies, Roads in Roman Britain (Stroud, 2002).

${ }^{6}$ Christopher Taylor, Roads and Tracks of Britain (London, 1979)

${ }^{7}$ Brian Paul Hindle, Roads and Tracks for Historians (Chichester, 2001).

${ }^{8}$ Shirley Toulson, The Drovers (Princes Risborough, 1988).

9 Arthur Raistrick, Green Roads in the Mid-Pennines (Ashbourne, 1991).

${ }^{10}$ David Harrison. The Bridges of Medieval England: Transport and Society 400-1800 (Oxford, 2004)

11 John Blair (ed.) Waterways and Canal-Building in Medieval England (Oxford, 2007).

${ }^{12}$ PN NTP., p. 4

${ }^{13}$ DEPN

${ }^{14}$ CDEPN

${ }^{15}$ MILLS

${ }^{16}$ G.B. Grundy, Archaeological Journal, 75 (1918), 98 (1931), 96 (1939), 98 (1941). See Bibliography

${ }^{17}$ Hooke, Anglo-Saxon.
} 
Gelling $^{18}$ used a different approach taking individual topographical place-name elements and ascertaining just what landscape feature each referred to. Her work progressed sufficiently, aided, among others, by Cole's more detailed studies of individual elements, for her to write an updated version The Landscape of Place-Names in $2000 .^{19}$

There has, however, been little cross-fertilization between the two fields of study. Those studying roads have made only limited use of place-name evidence, the main exception being the use of strōet to indicate the presence of a Roman road. ${ }^{20}$ Other names such as Stan-, Stane, Stone, Ridgeway, Ford, Coldharbour and Caldecot, also mentioned by Margary, have subsequently oft been repeated, largely uncritically, as indicators of Roman roads (see chapter 5 under Coldharbour), but without examples of their effective use except by The Viatores. ${ }^{21}$ Most other place-name terms that refer to routes have seemingly escaped these authors' attention entirely.

Those with an interest in place-names which describe routeways have likewise hardly applied their knowledge to individual routes, preferring instead more general comments understandable considering the infancy of the study and the rather few people who study both place-names and routeways. An idea of the modest progress made in the last twenty years can be gleaned from comparing the introductions to the third chapter of Place-Names in the Landscape published in $1984,{ }^{22}$ with that in The Landscape of Place-Names which was first published in $2000 .^{23}$

Concerning crossing places in 1984, Margaret Gelling commented that 'Major settlement names in -ford do not appear to have been counted previously, they are more frequent than I had realised' and 'The rare words feer and geläd were probably specialised, but it is very difficult to discern their meaning from the evidence now available'. By 2000 she was able to write '...OE speakers had more specialised terms than ford for crossings which presented exceptional difficulties, the ones discussed here being foer, geläd and gewaed'.

In 1984, commenting on settlement names which refer to roads, 'Here again there is scope for further investigation by people with local knowledge. It is not at all clear why Broadway should have its distinctive name'. This remained the position in 2000 when she wrote 'Unlike other "road" terms discussed in this chapter, weg appears to have had no specialised sense'. This comment was made before the detailed work on weg discussed in chapter 3 had been done

More progress had been made in the case of hyth because Gelling's hesitant suggestion made in 1984 that 'The assembling of major names containing hỹth was a rewarding exercise, bringing out the two main concentrations, on the River Thames and in the Fens. ... such names are rare enough to suggest that a $h \bar{y} t h$ was a noteworthy feature, perhaps an inland port, and this is of some significance for regional history.' is replaced by 'It is clear from the distribution and siting of some wetland hỹth names ... that this element relates to organised transport systems...'

In 2000 Gelling wrote 'The oft repeated strēet-tiun is probably more than a simple observation that the settlement referred to is beside a Roman road. Like many recurrent tün compounds Stratton/Stretton may be suspected of having functional connotations. These places may have offered some facilities to people using the roads'. The notion of functional tüns had

\footnotetext{
${ }^{18}$ Margaret Gelling, Place-Names in the Landscape (London, 1984)

${ }_{19}$ Margaret Gelling and Ann Cole, The Landscape of Place-Names ( Stamford, 2000; reprinted Donington, 2003). Margaret Gelling wrote the greater part of the text incorporating her own and others' research, while Ann Cole produced the maps and sketches and the Chiltern section.

${ }^{20}$ Margary, Roman Roads, l, p. 20

21 The Viatores, Roman Roads in the South-East Midlands (London, 1964), passim

${ }^{22}$ Gelling, Place-Names, pp. 62-3.

${ }^{23}$ Gelling and Cole, Landscape, pp. 65-6
} 
developed since 1984 and was being applied to a number of groups of place-names, see for instance comments on $\bar{e} a-t \bar{u} n^{24}$ or $\bar{a} c-t \bar{u} n .^{25}$

A link between travellers and the naming of settlements was suggested in 2000 when Gelling wrote 'In the introduction to this book attention is drawn to the possibility that travellers' perceptions of landscape features might have played a significant part in the naming of settlements'. In this introduction Gelling says 'Some landform terms show a more than accidental relationship to known ancient routes, like the Icknield Way, and to the major Roman roads which retained their importance through the middle ages' (p.xvi). The Landscape of Place-Names, however, was not a suitable work in which to follow up these comments closely, although reference is made under ofer (p. 200) and ora (pp. 204-6) to the relationship of one pair of landscape terms to routes.

It is evident that in the years between 1984 and 2000 Margaret Gelling was beginning to put into words the connections between travellers and the place-names along old routeways: the idea of an organised transport system, the existence of functional tüns and the use of carefully named landscape features in routeway-finding all make their appearance in her work.

Meanwhile an article by Ann Cole ${ }^{26}$ described in rather general terms how certain placename elements might inform travellers about the nature of their routes: the steepness of wegs was foreshadowed, the flood-proneness of gelāds described, the distribution and possible function of the drag-tüns and draeg-cots were noted. Terms not obviously describing routes but which nevertheless appear alongside them, such as mere-tün and byden-wella, were reported. The present study seeks to build on this earlier article by considering a wider range of settlement names in greater detail and relating them to particular roads, thus building up a picture of the main routes in use in the early medieval period.

Before the place-name evidence is presented some consideration of the travellers, the roads and waterways, and the place-names themselves is desirable to provide a background to the discussion.

ROADS, WATERWAYS AND THEIR USERS

1) The travellers

A distinction needs to be made between those who travelled very locally from their homes to the fields and woods where they worked or to the nearby markets, and those whose occupations involved them in travelling longer distances, maybe even overseas. In looking at an England-wide major routeway network it is the needs of the longer distance travellers that must be considered: that distance is taken to be more than one day's journey. If someone was travelling for longer than a day he or she would need water, food and shelter, and some means of knowing which route to follow. Doubtless many travellers using a route for the first time were in the company of those who had used the route before and so knowledge about the route was passed on from person to person.

People from many walks of life would have used the roads and waterways. The king and his retinue moved from place to place, dispensing justice, confirming grants and living off the food-rents due to the king. Churchmen were frequent travellers; some made pilgrimages to Rome involving a sea crossing, or to shrines in England such as Glastonbury, Winchester and St Albans; others were missionaries travelling from place to place teaching. Bede describes many such activities: for instance, Paulinus visited the royal palace at Yeavering, Northumbria, where he instructed both the court and 'the crowds who flocked to hear him from every village and district'. Paulinus also preached in the kingdom of Lindsey, held a baptism at Littleborough on the Trent, was bishop of York and then of Rochester. He took Queen

\footnotetext{
${ }^{24}$ Gelling, Landscape, p. 14.

${ }^{25}$ PN. SHR., 1, pp. 1-4; Margaret Gelling, The West Midlands in the Early Middle Ages (Leicester, 1992), pp. 123-5

${ }^{26}$ Ann Cole, 'The Anglo-Saxon Traveller', Nomina, 17 (1994), pp. 7-18
} 
Æthelburh by boat from Northumbria to Kent using the east coast sea route. ${ }^{27}$ Traders came from the continent to the south and south-east coast ports: trading centres grew up, notably at Hamwic and Lundenwic (Southampton and London). From these landing places the imported goods were moved far and wide, whether in the hands of one trader moving long distances or passing from one trader to another, each travelling a shorter distance. Some of these overseas trade items were travelling long distances, for instance pottery, glass, metalwork and stone have been found many miles from where they were produced. ${ }^{28}$ Goods produced in England were also moved over considerable distances; for example Ipswich ware has been found throughout East Anglia but also in Kent and Yorkshire (see chapter 10). ${ }^{29}$ Salt produced in Droitwich and Cheshire was moved in large quantities along customary routes known as saltways where, amongst other traffic, the carts and pack trains of the salt merchants would often have been seen. In the late Anglo-Saxon period high quality stone was being quarried and moved to building sites - Taynton stone down the Thames to Oxford ${ }^{30}$ Barnack stone through the Fen waterways to Ramsey, ${ }^{31}$ and Oolitic Limestone, possibly from Stonegrave YON, to build the York Tower was also moved mostly by river. ${ }^{32}$ Less welcome travellers would be the raiders and armed men: particularly feared were the Vikings. The Anglo-Saxon Chronicle records many of their movements, and it seems clear that they were able to move around the countryside comparatively easily when unopposed: for example, in 894 [893] raiding armies gathered at Shoebury ESX, then went up along the Thames and were joined by reinforcements from East Anglia and Northumbria. Together they 'went up the Thames until they reached the Severn, then up along the Severn'. ${ }^{33}$ In 911 [910] the raiding army (Vikings) left Northumbria and raided across Mercia. In response the king, who was in Kent, sent his men from both Wessex and Mercia to fight, and put to flight the raiders. This all suggests a lot of coming and going by messengers bringing reports of the enemies' movements and summoning the King's (Edward the Elder) men prior to the engagement, as well as the movement of the fighting men. ${ }^{34}$ These would not have been the only groups of travellers: there were probably craftsmen (stonemasons, carpenters, carvers, smiths), drovers, fugitives and thieves to be seen too.

\section{2) The roads and tracks}

Trackways had been developing in the English countryside ever since the final retreat of the ice and the subsequent re-colonisation of the land by animals and mankind. By the end of the Roman period the lowlands would have been criss-crossed with a network of tracks, the highlands less so. Prominent among the tracks would have been the roads built by the Romans - typically straight, raised on a bank (the agger) and with a firm man-made surface. A few long-distance prehistoric tracks such as the Icknield Way, the Great Ridgeway and Pilgrims Way would also have been prominent in the landscape. The roads shown on the O.S. Map of Roman Britain (third edition) are in effect the starting points of this study; they are deemed to have been visible in the landscape and available for use by the earliest Anglo-Saxon incomers as routeways or sometimes as boundaries. Which of the other numerous tracks existed and were used at this time (c. $5^{\text {th }}$ century) is difficult to say but, as will become evident later, some

\footnotetext{
${ }^{27}$ Bede, The Ecclesiastical History of the English People, trans. J. McClure and Roger Collins (Oxford, 1944). II, ch. 14, pp. 97-8; II, ch. 16, p. 99; II, ch. 16, p. 100; III, ch. 14, p. 131; II, ch. 20, p. 106.

${ }_{28}$ Michael Lapidge (ed.), The Blackwell Encyclopaedia of Anglo-Saxon England (Oxford, 2001), p. 453

${ }^{29}$ Lapidge, 'Encyclopaedia', p. 254.

${ }^{30}$ John Blair, Anglo-Saxon Oxfordshire (Stroud, 1944), p. 122

31 J.S. Alexander, 'Building Stone from the East Midland Quarries: Sources, Transportation and Usage', Medieval Archaeology 39 (1995), p. 115.

${ }^{32}$ G.E. Morris, 'The Significance of the Place-Name Stonegrave', JEPNS, 17 (1985), pp. 14-9.

${ }^{33}$ The Anglo-Saxon Chronicles, trans and ed. Michael Swanton (London, 2001), p. 87, s.a.894 [893]

${ }^{34}$ Swanton, $A S C$, p. 96, s.a.911 [910].
} 
of these routes can be identified by the place-names alongside them. Meanwhile it is also possible to identify some other routes that are definitely many centuries old and which might have been in use as far back as the early medieval period. For instance, there are other known stretches of Roman road which do not occur on the O.S. Map of Roman Britain but are described in Margary or elsewhere (in the lists in the Appendix they are called 'minor Roman roads' and references are given). Salt was being sent out from Droitwich in pre-Roman and Roman times, so a network of saltways existed then. As salt was such an essential item, some sort of trade in it probably survived through the upheavals of the end of the Roman rule and the Adventus Saxonum, and so some saltways are likely to have been in use in the very early medieval period. The ridgeways along the crests of the chalk escarpments of south-east England make good dry routeways so it is possible that some 'prehistoric trackways in contemporary use' other than those shown on the O.S. Map of Roman Britain were used: the Salisbury Way WLT, and North Hampshire Ridgeway for example. Sherratt suggests that river valleys were followed in the prehistoric period in preference to ridgeways (see Chapter 9 , p.107). Anglo-Saxon charter boundaries often refer to roads. If the boundary clause can be solved, short stretches of old routes, mostly strēet, weg and, in southern counties, herepceth and herestrët, can be identified.

These four categories of road (Roman, salt ways, ridgeways, routes in charter boundaries) existed before or during the early medieval period. For other routes there is only post-Conquest evidence: it is possible that these routes existed and were used in the early medieval period but they are not mentioned in the surviving documents of the time.

The earliest surviving map attempting to show the British Isles realistically is that of Matthew Paris drawn about $1250 .{ }^{35}$ Four versions exist and show the route from Canterbury to London, Newcastle and Berwick. The shape of Britain is poor and the route is indicated by a series of names on the map: the road is illustrated diagrammatically by a line. Although this map tells us of a route from Canterbury to Berwick it is insufficiently detailed or accurate to identify exactly which roads were being used. However the section from Canterbury via Rochester to London is likely to be the Roman road M 1b/ M 1c. The northern part seems to correspond with the Great North Road and the central part with other stretches of Roman road such as M 1d, M le, M 28 and M $8 .^{36}$

The Gough map of c. 1360 is much more useful. ${ }^{37}$ Britain is a much better shape and numerous routes are shown as lines connecting named settlements. Long distance routes radiating from London to Cornwall, Bristol, Gloucester and South Wales, Chester and North Wales, Lancashire and Carlisle are drawn. There are some cross-country routes and some local routes in Yorkshire and Lincolnshire as well, but there are some curious omissions such as the London - Dover and London - Ipswich routes and the Icknield Way. These Gough routes were obviously well established by 1360 . It is possible, though not proven, that they are much older and might have existed and been in use in pre-Conquest times. However, the map only gives a partial picture of the main roads in use in c. 1360.

County maps began to appear in the latter part of the sixteenth century, for instance Saxton's in the 1570s. John Norden, working in the 1590 s, seems to have been the first map-maker to have included roads on his county maps, but they only cover Middlesex, Hertfordshire, Surrey, Sussex, Hampshire and possible Warwickshire. ${ }^{38}$ The information on these and other maps was incorporated into Camden's Britannia (1607 edition). It was a widespread practice to revise and reprint volumes of maps incorporating other people's work as did Robert Morden in his 1695 version of Camden's Britannia. He incorporated roads shown by Norden and Ogilby

\footnotetext{
${ }^{35}$ P.D.A. Harvey, Medieval Maps (London, 1991), p. 71.

${ }^{36}$ This is the numbering system used by I.D. Margary for Roman roads.

${ }^{37}$ Nick Millea, The Gough Map (Oxford, 2007), esp. pp. 27-32

${ }^{38}$ R.V. Tooley, Maps and Map-Makers (London, $6^{\text {th }}$ ed. 1978), p. 66.
} 
and from consulting 'knowing gentlemen'. ${ }^{39}$ Morden's roads sometimes differ from those shown by John Ogilby whose excellent and very detailed road atlas was published in 1675 : it showed many major routes in England and indicated the by-roads leading to villages a few miles distant. ${ }^{40}$ It is possible to follow many of these routes exactly on a modern O.S. map three hundred years later. Where the Ogilby map appears to show the same route as the Gough map it is likely that the route had existed with only minor modifications between the mid fourteenth century and 1675 . Therefore, it is not unreasonable to believe that the route shown in detail by Ogilby was much the same as that used in the time of the Gough map. If routes can survive almost unaltered for three centuries (1360 - 1675, and 1675 - present day), then it is not unreasonable to suggest that the Gough routes were in use three centuries earlier - and this would take us back to the early medieval period. This idea is supported by the rate of survival in use of the roads shown on the O.S. Map of Roman Britain: modern roads, tracks and footpaths are on or follow the line of approximately $64 \%$ by length of these roads (my estimate).

Approaching the problem of identifying old roads from the other end of the time line, it is possible to eliminate many routes shown on modern maps as possible survivors of the early medieval routes by seeing if they existed on the early editions of O.S. maps: the Cassini and Timeline Historical Maps are useful in this respect as many show the situation before the railways were built. ${ }^{41}$ Such features as motorways and by-passes can quickly be eliminated as possible survivors from early medieval times.

Therefore, in considering what routes might have existed in the early medieval period there are three groups. Firstly, those most likely existing at the start of the period (prehistoric tracks, Roman roads, saltways, and some charter boundary routes). Secondly, routes known to be centuries old from the Gough and Ogilby maps' evidence. Thirdly, those known not to have existed because they are not on the early O.S. maps. Undoubtedly, there is other evidence to be found about the existence or construction of early routes and reference is made to them in the appropriate places.

The identification of the waterways in use in the early medieval period is much easier. Britain had been surrounded by sea since the English Channel had formed about 6,000 BC following the end of the ice age. Since then gradual modifications to the coastline have affected the siting of havens and landing places: some of those occurring in the last 2,000 years are described in chapter 6 . Rivers have followed much the same courses during the last 2,000 years with only minor natural modifications such as meander migration. The natural routes they provided have remained: there has been access from the southern North Sea into the heart of the South Midlands along the Thames; access from the North Sea through the Humber northwards along the Ouse to York, or south and west up the Trent to the North Midlands. From the western approaches there was access up the Bristol Channel, along the Severn and Wye, to the Welsh Marches. However, not all rivers were navigable. Some were too shallow, especially in dry periods, or too dangerous when in spate; some were too rocky; some had rapids and waterfalls; some smaller ones had such tight meanders that they were hardly worth using. A river was only useful for travel if it led in the direction that the traveller wished to go: direction was something that man could not control. Man did, however, attempt to modify the waterway network to improve its usefulness by digging canals. There was nothing as ambitious as the $18^{\text {th }}$ century canal building, but evidence has been assembled to show that

\footnotetext{
${ }^{39}$ Brian Paul Hindle, Maps for Local History (London, 1988), p. 24.

${ }^{40}$ John Ogilby, Ogilby's Road Maps of England and Wales from Ogilby's 'Britannia' ed. Roger Cleeve (Reading, 1971).

${ }^{41}$ Timeline Historical Maps are early O.S. maps re-projected and re-scaled to match the O.S. Landranger maps, published by Timeline Maps Ltd. Other maps in the series are called Cassini Historical Maps, Old Series, and are published by Cassini Publishing Ltd.
} 
Roman canals such as Car Dyke and some short stretches of Anglo-Saxon cuts and canals were made. There are examples along the Thames. ${ }^{42}$ Later on in the middle ages there were constant complaints from boatmen about the obstructions to navigation caused by mills, weirs and fish traps, and the value of rivers as highways was lessened. In modern times, with the advent of rail and motorised road traffic, our rivers and canals are seldom used for moving goods commercially.

As noted earlier, it is regular usage that keeps a road open. Any track no longer in use is soon encroached upon by scrub, becoming impassable. The Roman roads need not have been kept open only by long distance travellers, people using them frequently for short local journeys would have played an important part in keeping them passable. Indeed, if a road was not used by long distance traffic, but only by local traffic here and there, it could account for the intermittent survival as modern routes of some Roman roads, for instance Lincoln to Burgh le Marsh, M 27; Cirencester to Alchester, M 16b, and London to Braughing, M 2a. On the other hand, as conditions changed, and especially when bridges were (re)constructed or new opportunities for commerce opened up, new routes may have needed bringing into being as has happened in recent decades with the development of the motorway network. A route may change in status as it declines or increases in use or importance: for instance, the Icknield Way is no longer an important trade route, but it is well used for recreation and access to farmland.

3) Factors affecting travellers and the modes of transport they chose

a) Speed, load, distance and method of travel

The facilities that the long distance (over one day's journey) travellers might want and at what intervals, depends on what mode of transport was used and therefore how far could be travelled in one day. The chief modes of transport were walking, riding and by cart (or by boat) but within these categories there are big variations. Someone on foot and unencumbered could average 15 to 25 miles a day. A jagger in charge of a pack train might cover 15 miles in hilly country or 25 in better conditions. ${ }^{43}$ A drover would probably not cover more than 12 miles a day lest his animals should lose condition, and therefore value, before reaching their destination. ${ }^{44}$ A cart carrying salt moved about 12 miles a day. Markets were seldom less than 10 miles apart suggesting that a round trip of 20 miles was practicable in a day. If the majority of travellers covered about 20 miles a day, the facilities catering for water, food and shelter might be expected to be about 20 miles apart: this is the figure used in this study, but it is only an approximation depending on conditions which might involve the type of transport used, the road surface, the relief, the passability of any river crossings and the weather. A number of place-names provide information on road conditions that would be helpful to anyone planning a journey. They are the subjects of later chapters.

When animals were use, the choice varied. The pack animals had the load lashed to their backs, and in earlier times donkeys, asses and mules were preferred to horses because they were more economical to feed, were healthy and sure-footed, and, though smaller, could carry almost as much as a horse. ${ }^{45}$ The draught animal used was the ox. Oxen were less temperamental than horses and more willing to go on pulling when a cart proved difficult to move. ${ }^{46}$ Early horse yokes (resembling ox yokes) pressed on the horses' windpipes preventing them from pulling heavy loads, but the introduction of the horse collar, probably by the Vikings who had adopted the idea from Turkic speakers, multiplied their effective pulling strength four or five times and also allowed some measure of braking; it was in widespread use

\footnotetext{
${ }^{42}$ Blair, Waterways, especially chapters 7 and 12 .

${ }^{43}$ Hindle, Roads and Tracks, p. 70

${ }^{44}$ A.E. Dodd and E.M. Dodd, Peakland Roads and Trackways, (Ashbourne, 1980), p. 126

${ }^{45}$ Norbert Ohler, The Medieval Traveller, trans. Caroline Hillier (Woodbridge, 1989), pp. 15-17.

${ }^{46}$ Martin Watts, Working Oxen (Princes Risborough, 1999), pp. 11, 17.
} 
in Europe by the eleventh century, ${ }^{47}$ and increasingly used in England from the twelfth century. ${ }^{48}$ Horseshoes were widely used in Europe by the ninth century, increasing the horse's surefootedness on steep or icy roads. ${ }^{49}$

The construction and durability of the carts and wains (OE wcegn) were also important factors. ${ }^{50}$ In later centuries there are records of problems with broken wheels, broken axles and poor braking systems just as there must have been in earlier times. Jolting of the cart on rough, stony roads or the strains imposed when dragging a cart out of a morass must have undermined the roadworthiness of many a vehicle, so much so that the pack animal was often preferred. Although in the seventeenth century few carts were to be seen on the roads, so damaged had the latter become, back in the fourteenth century there are records of the potential use of various roads for carts; for example, Stokesbryggeslane at Crowmarsh (near the Thames at Wallingford OXF, was 'full of water and floods so men with horses and carts could not pass' (t. Ric.II) and a road called Fosse by Fosse Bridge (Kineton WAR,) 'so ruinous that no cart can pass' in $1387 .{ }^{51}$ When choosing a method of transport, the weight of the goods moved, and the speed and distance of movement had to be considered. A man could carry only a quarter that of a pack pony, mule or donkey, 54-66 lbs as opposed to $220-330$ lbs ( $1 / 8$ ton), ${ }^{52}$ (up to $375 \mathrm{lbs}$ for a horse). A two-ox waggon-load of salt from Cheshire weighed 8-12 cwt (c. $1 / 2$ ton). ${ }^{53}$ A train of twenty pack animals could carry $4,400-6,600 \mathrm{lbs}$ (approximately 2-3 tons), comparable to that of a four-ox cart, and twice that of one horse and cart well harnessed together $(2240 \mathrm{lbs}=1 \mathrm{ton})$. The Graveney boat (cross-channel, tenth century) could carry about 7 tons. ${ }^{54}$

In some situations the speed of movement could be important: a messenger carrying urgent information could average 12-15 miles an hour on horseback, or 6-7 miles an hour as a runner and perishable goods such as fish would need to be moved as quickly as possible. In contrast pedestrians would move at 2-4 miles an hour, carts or a drover with cattle only about $2-21 / 2$ miles an hour.

The distance that could be covered in a day might also have to be considered. As noted above, on foot a traveller could cover $15-25$ miles a day at $2-4 \mathrm{mph}$; a (salt) waggon about 12 miles a day; a merchant $20-30$ miles a day; a rider in a hurry $30-40$. A sailing ship at 3 mph covers $75-125$ miles, or with favourable winds and currents moving at 7-8 mph, covers 75-200 miles; a Viking longboat sailing at $11-13 \mathrm{mph}(9-11$ knots $)$ covers about 95 miles. ${ }^{55}$

The condition of the road surface and the steepness of the gradients could also affect the choice of mode of transport. Roads could be so muddy in winter as to be impassable by carts, while the gradients could be too steep for carts to negotiate safely. Some roads could be so deep-cut and narrow that carts were unable to pass one another: the lanes through the Upper Greensand in Surrey, for instance. Tracks over mountainous areas could be boulder-strewn as

47 A.C. Leighton, Transport and Communication in Early Medieval Europe (Newton Abbot, 1972), pp. 108-12. Leighton notes that 'The derivation of the word hames (the rigid side-pieces of the collar) from a Turkic dialect of Central Asia, the finding of metal horse-harness mountings in ninth-century Swedish graves and the mention of ploughing with horses in Norway ... indicate a possible introduction of the horse-collar by the Vikings from their Russian contacts'. pp. 108-9.

48 John Langdon, Horses, Oxen and Technological Innovation (Cambridge, 1986), ch. 2

49 Leighton, Transport, p. 106; Lionel Casson, Travel in the Ancient World (London, 1979), p. 181

${ }^{50}$ Strictly speaking, carts were normally two wheeled and wains or waggons four wheeled.

${ }^{51}$ Public Works in Medieval Law, ed. C.T. Flower (Selden Society, 40, 1923), pp. 129, 222

${ }^{52}$ L. T.C.Rolt, Navigable Waterways (London, 1969), p. 1.

${ }^{53}$ Leighton, Transport, pp. 41, 104

${ }^{54}$ Rolt, Navigable, p. 1.

55 Ohler, Medieval, p. 101. F.M. Stenton, 'The Road System of Medieval England', Economic History Review, 7 (1936), p. 16 
well as steep and thus unsuitable for wheeled vehicles, and so if goods needed to be carried, pack-trains were often the best choice of transport.

b) Weather

Travellers were affected by the weather. In some situations this could determine the route used or whether the journey was practicable at all. Long wet periods could result in rivers being dangerously full and fast-flowing, causing floods on adjacent land. Approaches to river crossings could be difficult and the fords too deep and dangerous to use until the river had subsided (see under geläd and drag for place-names related to these problems and under ford for names describing the ford's usability). Prolonged wet weather could also make roads over clay and alluvium so muddy as to be impassable (see under drag), but a period of frosty weather could harden the muddy ground enough to make it passable again - if bumpy.

Snow, fog, cold weather and/or strong winds could be hazardous for travellers in upland areas, even causing death from exposure especially in rather featureless areas such as parts of the Peak District or Dartmoor. Even in lowland England the higher hills sometimes had names calling attention to snow lingering on: Snowshill GLO, on one of the high points of the Cotswolds and lying on a saltway, is one. Christmas Common, in the Chilterns above Watlington OXF, often has a dusting of snow in the winter when the country all around is clear. Knightsbridge Lane, an old route, goes over Christmas Common: the origin of 'Christmas' in this context is very uncertain - a reference to snow is one of several possible explanations.

Occasionally, place-names call attention to routes that are only passable in summer. The ford at Great Somerford GLO/WLT is easily passable in summer when the infant Avon is so low that the gravelly bottom is exposed here and there. In winter the river is much deeper and floods over the adjoining meadows.

One of the problems of travelling with animals in winter is the lack of grazing by the wayside, because with temperatures below $6^{0} \mathrm{c}$ grass growth practically ceases. Once the herbage has been grazed down some other source of fodder must be sought (see under 'Fodder for Animals' chapter 5).

In spite of the drawbacks to winter travel, many journeys were undertaken in the winter months. Hindle analysed the itineraries of kings John, Henry III, Edward I and Edward II in the thirteenth and fourteenth centuries, counting up the number of journeys made each month by each king and his retinue of carts - often twenty or more. He found that kings travelled extensively in winter as well as summer. He noted that Edward I covered the 360 miles from Bamburgh to Windsor in 25 days in January 1300 , including six days when he did not travel. Three hundred and sixty miles in 19 days is 19 miles a day, closely comparable with the 20 miles a day that I have assumed the average traveller to cover. ${ }^{56}$

Consideration of weather conditions was even more vital for seafarers. At sea, strong winds could endanger shipping: boats might be driven onshore and wrecked, blown out to sea, or capsized and lost.

c) Facilities

Road travellers had other needs: people undertaking a journey of more than a day would need food for themselves and fodder or grazing for their beasts, as well as water. Although travellers sometimes slept under the stars, a dry and comfortable shelter was more desirable, especially in bad weather. Travellers who met with problems along the road, such as their carts getting mired or rivers being too dangerous to ford, would appreciate assistance from local people. The 'functional tüns' probably fulfilled some of these needs.

\footnotetext{
${ }^{56}$ B.P. Hindle, 'Seasonal Variations in Travel in Medieval England', Journal of Transport History, new series, 4 (3) (Feb. 1978), pp. 170-8.
} 
Functional $t \bar{u}$ ns are a comparatively recently recognised group of place-names. They are settlements which, besides the usual farming activities, derived some benefit and/or had to perform some duty as a result of their proximity to an estate centre or a specific feature, for instance a pond, road, woodland or river. The possible functions of some mere-tüns as watering places, ${ }^{57}$ of $s t r \bar{e} t-t \bar{u} n$ s as overnight halts, ${ }^{58}$ of $w u d u-t \bar{u}$ s playing a special role in the handling of timber, ${ }^{59}$ of $\bar{e} a-t \bar{u} n$ s keeping rivers open for navigation, have been suggested. ${ }^{(0)}$ Some other topographical elements have a substantial proportion of their examples in the form 'element $+t \bar{u} n$ ', and these may well be further examples of functional $t \bar{u} n s$, although just what the functions are has yet to be ascertained. The drceg-tüns and $m \bar{o} r$-tüns are considered later. Others, such as the hōh-tüns and halh-tüns, appear to have functions as yet unidentified but evidently not associated with route-ways (for further discussion see vol. 2, pp.3-4)

Early medieval travellers would need some method of finding the way. For people using the same routes regularly, this would not be a problem once they had learnt the way. The knowledge could be passed on from experienced travellers to those new to the route. For those using a route for the first time and without such guidance, one way would be to memorise the places in order along the route and to ask at each place for directions to the next one.

Distinctive landmarks could be helpful, just as today we may say 'up the hill and left at the traffic lights...'

d) Law of the Highway

Besides the environmental constraints experienced by travellers there were man-made ones too, and some of these are expressed in the Law of the Highway. Certain regulations regarding highways, having their roots in Anglo-Saxon laws, have come down to us through the Leges Henrici Primi which date from c. 1113-1118. These laws are concerned with identifying the highways that came under the king's jurisdiction and ensuring the safety of road users. ${ }^{61}$

Leges Henrici Primi define the highway as 'the via regia which leads into a city (in civitatem), a borough (burgum), a castle (castrum) or royal portus (portum regium)', it is uncertain whether the latter means a market town or a sea port. An earlier document of $c .1080$ says a highway is a road linking city to city, market to market, or one sea port to another. Major routes identified by the place-names along them might be expected to link such places. The early use of the term 'civitas' is thought by Stenton and others to refer to sites of Roman occupation. Such sites were often called -ceaster by the Anglo-Saxons although by the twelfth century its use embraced other urban areas: ${ }^{62}$ Indeed, the Roman roads, strong candidates for roads-in-use in the early medieval period, do link -ceaster to -ceaster as one would expect and as will be noted later. Whether the roads-in-use identified from the place-name evidence link burh to burh or sea port to sea port is discussed under 'Conclusions', chapter 11 .

Although no mention is made of any duty to keep the roads in a good state of repair (unlike the duty of bridge-work, see chapter 4), people were forbidden to damage the road by blocking it, diverting it, digging holes in it or encroaching upon it. It was to be wide enough for two oxcarts to pass, or of two goad-lengths (a goad was about $16 \mathrm{ft}$ long), or to allow 16 knights to ride abreast. By comparison, an important Roman road had a paved width of about $30 \mathrm{ft}$, lesser roads $15-18 \mathrm{ft}$, although the agger was wider. These prohibitions and requirements appear in Leges Henrici Primi, but not explicitly in the Anglo-Saxon law codes.

\footnotetext{
${ }^{57}$ Ann Cole, 'The Distribution and Use of the OE Place-Name mere-tūn', JEPNS' 24 (1992), pp. 30-41.

${ }^{58}$ Cole, Anglo-Saxon, p. 12.

${ }^{59}$ Gelling and Cole, Landscape, p. 258.

60 Gelling and Cole, Landscape, p. 14

${ }^{61}$ This section is based on Alan Cooper, 'The Rise and Fall of the Anglo-Saxon Law of the Highway', Haskins Society Journal, 12 (2002), pp. 39-69.

${ }^{62}$ Frank Stenton, Anglo-Saxon England (Oxford, 1971), p. 526
} 
It was important to keep the highway safe for travellers. There were severe penalties for thieves, and for murderers who attacked strangers. One way of reducing arguments and potential trouble over costly transactions was to have them take place in the presence of witnesses, generally in a market town. If any stranger left the highway he was to make his presence known by shouting or blowing on a horn so that he would not surprise people unaware of his presence or seem to be skulking around like a thief.

The traveller, then, was relatively safe on major highways so long as he obeyed the rules and kept to the road. The effect of these laws was probably to concentrate traffic on these highways. How the traveller fared if he left the main road to reach a watering point for his animals or to find a night's shelter nearby we are not told. For the traveller, the nearer the facility to the road the better, because he could reach it more quickly and be less distant from the safety of the highway.

It has been observed that there are few settlements on such roads as the Fosse Way, Ermine Street and the Icknield Way as though there was a fear of roads and road traffic. While this may be true, long stretches of these roads go through waterless country and across locally high land, and so they would not be very attractive to settlement anyway, nor might a community want traffic damaging their cropland as it passed by. A place is likely to be a roadside settlement if it can gain some advantage from the passing traffic by offering some service to the travellers in terms of food, shelter or trading opportunities. The types of places found on the Roman roads are the strät-tüns, the strēet-fords and settlements with other crossing-place names. Places found nearby, sometimes on the road and frequently within a mile, are discussed in later chapters.

In the Roman Empire the existence of simple hostels, the mutationes, supplying food, bed, beasts and vehicles was widespread, the distances between them depending on the terrain and the demand. ${ }^{63}$ The Roman roadside settlements listed by Finch-Smith probably served this purpose in Britain. ${ }^{64}$ The concept of such provision may have been known to the AngloSaxons: it may be more than coincidence that four of the functional tün places discussed in later chapters, offering similar facilities to travellers, were on the sites of Roman roadside settlements: Merton SRY; Marton LIN; Long Stratton NFK; Stretton (Bridge) STF. In addition, Ewell SRY; Cheshunt HRT; Fenny Stratford BUC; Drayton Beauchamp BUC, and Fleet Marston BUC, with names informative to travellers, are also on the sites of Roman roadside settlements.

ORIGINS OF PLACE-NAMES

Since place-names are central to this study, some considerations of their origins and survival should be given.

a) A succession of names

At the end of the Ice Age, as Britain was re-peopled, natural features would have been given names, for it was essential for people to be able to pinpoint occupation sites, hunting and fishing grounds etc. for one another. Over the millennia other incomers from the continent would have introduced new cultures and languages. By the start of the first millennium A.D. places in England would mostly have had Celtic names with perhaps a few survivals in earlier tongues. In Roman times some places would have been given Latin names to exist amidst the Celtic (British) ones. Probably other Celtic ones would have been lost in this process. A much bigger change in the language make-up of names occurred as a result of the Adventus Saxonum. Large numbers of British and Latin place-names were lost and large numbers of Old English place-names were given. In northern and eastern England more big changes occurred as a result of the Viking settlement when further Latin and British names are likely to have

\footnotetext{
${ }^{63}$ Casson, Travel, p. 184

${ }^{64}$ Roger Finch-Smith, Roadside Settlements in Lowland Roman Britain (BAR British Series 157, Oxford, 1987)
} 
been lost, together with large numbers of Old English names, to be replaced by Old Norse names. The Norman Conquest had less effect on English place-names, although a few new ones arose and many Old English and Old Norse place-names had a Norman surname added, such as at Ashby de la Zouche or Compton Beauchamp. The point is that names were given and lost over the millennia, and the process was probably most rapid during times of invasion and conquest. Once written records are available it is possible to trace/identify some of these losses and gains. Names in use in Roman Britain, both Latin and British, are known from the Antonine Itinerary (c. 210) and the Ravenna Cosmography (7th century). ${ }^{65} \mathrm{~A}$ few of those in Latin have survived e.g. Catterick and Speen. Some in British have been modified, particularly by the addition of ceaster e.g. Manchester, Cirencester, Winchester, and some have been lost e.g. Camolodunum (Colchester), Verulamium (St Albans) and Duroliponte (Cambridge). ${ }^{66}$ It did not happen overnight, as Bede, writing in the early eighth century, records some names which survived from Roman Britain but which have since been lost: examples are Campodunum (now probably Doncaster) and Calcaria (now Tadcaster). He also records names in Old English that have since been lost; Tiouulfingacaestir now Littleborough, but in Roman times 'Segelocum', and Ythancaestir now probably Bradwell on Sea, but in Roman times 'Othona'.67

The process of name-change continued in the later Anglo-Saxon years. Some known examples of change from one Old English name to another are Medeshamstede to Burg to Peterborough NTP; Hreutford to Redbridge HMP; Baedericeswirde (S 507) to St Edmundsbury to Bury St Edmunds SFK, and Kitnor to Culbone SOM. Some known examples of change from an Old English to an Old Norse name are Northworthy to Derby, and Streoneshalch to Whitby. However, in the great majority of cases names are likely to have remained the same. Chertsey (S 1165) and Battersea (S 1248) which are mentioned in charters of 672-4 and 693 respectively, and Hertford HRT, and Tilbury ESX, which are mentioned in Bede, are amongst many other early names still current.

The examples above are names of settlements. What was the inspiration behind these names? What was thought to be a suitable name for a settlement? There are three main sources of names: the folk names referring to groups of people, the habitative names referring to dwellings, buildings, enclosures and the like, and topographical names referring to features in the landscape. In the topographical category the settlement may take its name from a river (as did Thame and Frome) or a hill-mass (Malvern), where it is evident that the river or hill name is the earlier. There is more uncertainty about names deriving from smaller features such as the grassy hill at Garsington or the sparkling stream at Shirburn. The sites of both Garsington and Shirburn, and numerous other similarly named villages and hamlets, were excellent places to establish a settlement and many of them would have been occupied in Iron Age and Roman times. The question of whether the Anglo-Saxons named the landscape feature first and that name was subsequently used of the nearby settlement as Ekwall describes, or whether the topographical name was given to the settlement as well as the landscape feature in the first place as Gelling suggests, is unresolved. ${ }^{68}$ Ekwall suggested under the heading 'original nature names' that names such as Oxford

'... at first designated a ford over the Thames. When a village grew up at the ford it was named from the ford, and Oxford, when used of the village, originally meant 'the village at Oxford".

He gives instances of elliptical names

\footnotetext{
${ }^{65}$ Richard W. Bagshaw, Roman Roads (Princes Risborough, 1990), p. 18

${ }_{66}^{6}$ Margaret Gelling, Signposts to the Past (Chichester, 1997), chapter 2.

${ }^{67}$ Bede, History, II, 14; IV, 23; II, 16; III, 22; Barrie Cox, 'Place-Names of the Earliest English Records' JEPNS, 8 (1976), pp. 12-56.

${ }^{68}$ DEPN, pp. xviii - xxi; Gelling and Cole, Landscape, p. xvii
} 
' $\ldots$ the nature name being preceded by a preposition, and an expression for 'homestead' or 'village' being understood. Twyning was originally Bituinceum 'between the rivers', i.e 'the place between the rivers".

He gives cet 'at, by'; binnan 'within'; bi 'by', beneopan 'beneath' as examples of these prepositions in use.

Gelling, on the other hand, believes that topographical settlement names

'... were applied to settlements which for the most part had been long established when

the speakers of English first saw them ... and that the Anglo-Saxons were naming both site and settlement'.

b) Reasons for name changes

If the settlements pre-dated the Adventus Saxonum they must have had British (or Latin) names. If, in the early medieval period, these same settlements eventually took their names from an OE hill or stream name like Garsington or Shirburn - names which had already been bestowed by the Anglo-Saxon years before, what were the names borne by these settlements and used by the earliest Anglo-Saxons? Did they use the British name or was it already lost? Did they refer to it by some general term equivalent to 'the farm, the hamlet, the cottage' before it got a more specific name? Ekwall gives many examples of locative names, and this method of naming could readily apply in situations where a settlement was established after the naming of the topographical feature, but it is a less satisfactory explanation of the origin of settlement names when there was already a settlement in existence when the Anglo-Saxons arrived on the scene. In this case Gelling's explanation, in effect that the feature and settlement were named at the same time, may have some appeal for it cuts out an awkward hiatus between the loss of the British name and the acquisition of an Anglo-Saxon one.

The situation is complicated by the fact that the earliest Anglo-Saxon settlements were often much smaller and more widely scattered than later ones. Excavations at Mucking reveal a drift of settlement about $1 / 2$ mile to the north-east during the fifth to seventh centuries. ${ }^{69}$ If the name means 'soft place, mucky', referring to the adjacent marshes and creeks as Gelling suggests, it is still appropriate in spite of the settlement drift. ${ }^{70}$ The Whittlewood project found that over half of the settlements studied had persisted on the same site from pre-850 to the present day, so that any topographical names among them would have remained appropriate. ${ }^{71}$ In Raunds, a scatter of small, dispersed settlements in the early to mid-Saxon period gradually consolidated into fewer, larger ones in the later Saxon period - a process continuing after the Conquest when the three Cottons were deserted. The names of the early hamlets are not known nor whether Raunds was always the name of the dominant settlement. ${ }^{72}$

There are instances known where a place seems to have had several names at more or less the same time, one of which became dominant and remained in use. Coin evidence shows that Axbridge SOM, was also known as 'Axport' (assuming that they are one and the same place). The former name, and the one that prevailed, described the location of the town - even if the feature referred to as brycg is not obvious to us today: the latter name, 'Axport', reflected its function as a commercial centre and a mint. Similarly, in connection with Hastings SSX, the terms Hoestingacaester and Hoestingaport also occur either on coins, in the Burghal Hidage or in ASC. ${ }^{73}$ The circumstances are unclear. Erosion could have destroyed any Roman buildings

\footnotetext{
${ }^{69}$ Helena Hamerow, Excavations at Mucking vol.2: the Anglo-Saxon settlement (English Heritage, London, 1993), p. 87.

${ }^{70}$ Margaret Gelling, in Hamerow, p. 96.

${ }^{71}$ Richard Jones and Mark Page, Medieval Villages in an English Landscape (Macclesfield, 2006), p. 84

${ }^{72}$ Michel Audouy and Andy Chapman, Raunds: The Origin and Growth of a Midland Village, AD 450-1500 (Oxford, 2009), pp. 3,9.

${ }^{73}$ Jayne Carroll and David N. Parsons, Anglo-Saxon Mint Names, I Axbridge - Hythe (EPNS, Nottingham, 2007), pp. 1-4, 151-7
} 
or the port that Haestingaceaster and Haestingaport once referred to. Alternatively, they may have referred to Pevensey. Hastings, in any case, shifted eastwards as a response to persistent flooding (see volume 2, p. 212 under Bulverhythe). Other examples are given in Carroll and Parsons - Bath and Chester for instance. ${ }^{74}$

In cases where change occurred it may be that:

i) The site remained occupied but the name changed because

- There was a change in the language of the population.

For example, in the cases of Whitby and Derby (above).

- There was a change in the place-name but not the language.

For example, in the case of Watcombe OXF, the hamlet on, or close to, the old site of Watcombe came to be called Howe from the adjacent Hoo Manor. ${ }^{75}$

The first part of the names of Tredington ('Tyrdda's estate') and Bibury ('Beaga's manor house') were of people living in the first half of the eighth century, what these places were called before that is unknown, but Gelling suggests that Bibury may have been called after the river Coln. ${ }^{76}$

At places like biscopes-tūn, muneca-tūn and prēosta-tūn (before they were granted to bishops, monks and priests, probably in the eighth, ninth and tenth centuries) it is not known whether there were named settlements there or not. ${ }^{77}$

ii) There was a break in occupation of the site:

- A retreat and then re-occupation such as would have happened in post-Conquest times with the laying waste of settlements in the north by William I, some of which were reoccupied while others became 'lost' places.

- There was a retreat from marginal land due to a deterioration in the climate exacerbated by the Black Death in 1349; occasionally these places were re-occupied. Richard Muir instances Cublington BUC, which lay abandoned after the Black Death until it was resettled at the start of the fifteenth century. ${ }^{78}$

iii) The name has survived but the population moved to a different site.

- Old Winchelsea was washed away by the sea during the storms of the later thirteenth century, but was re-built as New Winchelsea on higher ground nearby.

- Combe OXF, moved from the valley floor to the hill overlooking the cumb, partly as a result of the Black Death. ${ }^{79}$

-The site of Horspath has drifted a mile away from its original site by a spring. ${ }^{80}$

- Watcombe Manor was re-built a mile beyond the cumb in a less isolated position several centuries ago.

In spite of numerous examples of name change there are vast numbers of topographical names which are appropriate to their sites implying that the settlement has not shifted at all, or, if a settlement has shifted, it has not been so far as to make the name inappropriate. So, while it is clear that there have been name changes, there are great numbers of examples of name stability. The question is how did these names originate? Who coined them? Was there more than one suggested name for a settlement, and if so which became dominant and why?

c) Need for distinctiveness

\footnotetext{
${ }^{74}$ Carroll and Parsons, Mint 1, pp. 11-17, 82-91

${ }^{75}$ VCH Oxfordshire, vol. 8, p. 214

${ }^{76}$ Gelling, Signposts, pp. 181-2

${ }^{77}$ Thomas Pickles, 'Biscopes-tūn, muneca-tūn and preosta-tūn: dating, significance and distribution' in The Church in English Place-Names, ed. Eleanor Quinton (EPNS, Nottingham, 2009), pp. 39-107.

${ }^{78}$ Richard Muir, The Lost Villages of Britain (London, 1982), p. 224.

${ }^{79}$ K.J. Allinson, M.W. Beresford and J.G. Hurst, The Deserted Villages of Oxfordshire. Dept. of English Local History Occasional Papers 17 (Leicester, 1966), p. 36.

${ }^{80}$ Allinson etc., Deserted, p. 39
} 
A name should be distinctive, enabling anyone to distinguish between one settlement and another. If the settlement is relatively important the name needs to be distinctive within a large area. If the settlement is small and subsidiary to the main settlement it only has to be distinctive within an estate or small group of estates. ${ }^{81}$ For instance the estate name Blewbury BRK (now OXF), is apparently a unique name and therefore distinctive over a wide area, but within the estate were, according to a charter of 944 (S 496), the relatively common names of $\bar{e}$ ast-tūn (now Aston Gifford and Aston Upthorpe) and $m \bar{o} r$-tūn (now North Moreton and South Moreton). Watts ${ }^{82}$ lists 46 Astons, and there are 66 Mor(e)tons (fig.5.20).

Mark Gardiner made the point, referring to Shetland, that names like X's Farm, Y's Farm were only usefully distinctive if one lived in the neighbourhood and knew who $X$ and $Y$ were and where they lived. ${ }^{83}$ To someone unfamiliar with an area a name like Brook Farm or Cliff Farm was much more informative. Different name types may suit the needs of different groups of people. People going to the market at Axbridge would have found the name 'Axport' more relevant, for others seeking to use the bridge or causeway, 'Axbridge' was more helpful. In the case of Baedericeswirde/Bury St Edmunds it seems that eventually it was more important to know the settlement was the location of the shrine of St Edmund than the enclosure of Beaduric. Some places may have had several names depending on their usefulness to the user. One could envisage somewhere with a castle, a monastery, a landing place, a market and by a pronounced physical feature being referred to by five different names, but eventually with one becoming dominant, probably the one most widely known. Other places may only ever have had one name.

d) Givers of names

So how may these names have arisen? Were they given by the inhabitants of the settlement, by their neighbours in nearby settlements, by some higher authority or by people from afar?

i) Firstly, was it necessary for the inhabitants to give their settlement a distinctive name? Probably not when they were talking among themselves, but if they were elsewhere, at market for instance, they might need to tell someone else where they came from and how to find them, using some such phrase as (at) paem ācum ('at the oak tree') or bufan iege ('the place above the island'). This is a way in which locative place-names may have arisen: Bede uses this format, but in Latin. ${ }^{84}$

ii) Secondly, if the people of one settlement, call it A, needed to refer to others, call them B, $C, D$ and $E$, in the neighbourhood it would be helpful for them to give names to the others. Eventually each of these five settlements would end up with names given by the other four. Were the names given to A all the same? If they were different, how did one come to be dominant - was there a mutual agreement on which one to use? On the other hand, maybe one name was so obviously appropriate above all others, as Blewbury seems to have been, that there was (unconscious) agreement right from the start. This would be quite likely where there was a prominent landscape feature such as at Attercliffe YOW, or Eye HRE, SFK. It might happen where there was a settlement occupied/tenanted by a distinctive group of people, prompting names such as Prēosta-tūn (Preston), Biscopes-tūn (Bishopton) or Cnihta-tūn (Knighton). These may not have been original names because there would not have been priests and bishops before the coming of St Augustine in 597, and the x's tun type names are a feature of the later Anglo-Saxon period.

\footnotetext{
${ }^{81}$ This point is made by Ekwall (DEPN, pp. xvi-xvii).

${ }^{82}$ CDEPN

${ }^{83}$ Mark Gardiner, lecture at SPASE Workshop, Leicester, Feb. $28^{\text {th }} 2009$, echoing Nicolaisen's comments on Orkney names quoted in Carole Hough, 'Commonplace Place-Names', Nomina, 30 (2007), pp. 107-8

${ }^{84}$ DEPN, p. xix.
} 
iii) Thirdly, were the names 'imposed' from above? - 'above' being anything from the holder of the estate referring to his outlying settlements as the wic , the mōr-tün, the west-tūn, to 'government' officials compiling records, because the latter might also have used these general terms (whose meanings were widely understood, including by anyone reading the reports), in preference to, say, X's cot, Y's mōr or Z's tün. Margaret Gelling, trying to account for the many recurrent tün names, suggested that this may have happened in Shropshire. ${ }^{85}$ While these officially designated names could be a local or regional phenomenon, it would have been hard to impose on an England-wide scale, certainly before England was united as one kingdom. There may have been cases where a subsidiary settlement had one distinctive name used very locally and passed down in the oral tradition, and another of the more general recurrent-tün type used in documents and which was more widely known and more official: it was the latter which came to dominate. It is quite possible that certain names became established because they were those used by ('imposed' is too strong a word) those in authority over the local inhabitants, but it does not seem to have happened uniformly countrywide. A different variation on this theme is noted by Lewis along the Welsh Marches where settlements in Anglo-Saxon territory and bearing OE names yet were wholly or partly populated by Welshmen. The Welsh were hardly likely to have given their settlements OE names: it seems more likely that they were imposed by OE speakers. ${ }^{86}$

In this context, it is instructive to assemble the examples of 'topographical element $+t \bar{u} n$ ' to compare their relative numbers and overall distribution. This was done using the lists in The Landscape of Place-Names, ${ }^{87}$ themselves based on the information in DEPN and therefore generally representative of major names countrywide (see fig. 1.1, sheets 1 and 2). The topographical elements represented by only a few examples were omitted. It shows that some elements were frequently found in combination with $t \bar{u} n$ and others rarely if ever. The ones frequently combined were: $b r \bar{c} c, \bar{e} a$, mere, mersce, mōr, ströt, cumb, halh, clif, hōh, and wudu, followed closely by ég, dalr, denu, hop, scelf and gräefe. ${ }^{88}$ The proportion of the whole corpus of an element compared to that used in the form 'element $+t \bar{u} n$ ' varies: for instance, the denutüns are a small proportion of the denu names, but the $\bar{e} a-t \bar{u} n$ s are a high proportion of the $\bar{e} a$ names. Obviously, this data could benefit from further refining: the addition of other examples of the names listed in the county volumes but not in DEPN, although desirable, would unbalance the distribution picture because of the non-uniform coverage of the counties. As it stands this is only a rough and ready picture of the situation. The elements rarely, if ever, combined with tün are: bekkr, flēot, hamm, holmr, mos, brycg, path, weg, botmbotn, beorg, crüc, heafod, hlith, hrycg, öra, hangra, hyrst, lëah, sceaga, thveit, wald, aecer and land. One of the possible reasons for some elements not being found in combination with $t \bar{u} n$ is that they are Old Norse terms: bekkr, holmr, botn (but not botm) and thveit, but nor are these combined with by or thorp. Few road, crossing place or woodland terms other than strēet and wudu are combined with tün.

The distribution of 'topographical element $+t \bar{u} n$ ' names by county is also revealed: it ranges from Middlesex and Cambridge ${ }^{89}$ with none, to Shropshire with 48 . This is a coarse indication because the size of the county and the numbers of settlements in it will affect the density of $t \bar{u} n$ names in each county. Nevertheless, the figures show that in the south and east from Suffolk to Devon and also in the Lake District the numbers of 'topographical element - tün' names are

\footnotetext{
${ }^{85}$ PN. SHR. I, p. xiv.

${ }^{86}$ C.P. Lewis, 'Welsh Territories and Welsh Localities in late Anglo-Saxon England', in Britons in AngloSaxon England, ed. N.J. Higham (Woodbridge, 2007), pp. 131-6.

${ }^{87}$ Gelling and Cole, Landscape.

${ }^{88}$ The 17 examples of $h \bar{h} h$ in PN. YON are notable. No other element has more than seven examples in any one county.

${ }^{89}$ The Landscape of Place-Names ascribes a Welton to CAM in error for CMB.
} 
low. Counties in the north-east (Northumberland and Durham), the East Midlands and the South Midlands have moderate numbers. The counties with the highest numbers are in the West Midlands (Shropshire, Staffordshire, Cheshire, Warwickshire (but not Worcestershire ${ }^{90}$ )) with Lancashire, and the West and North Ridings of Yorkshire, i.e. there is a steady increase in numbers as one goes from south-east to north-west as far as Lancashire and Yorkshire. The important points to emerge are that if these names were 'imposed' from above it was not evenly done throughout England, and it was only done with selected topographical elements suggesting that there were particular reasons for such terms to be needed.

iv) Fourthly, in considering names useful to the traveller, one has to ask whether a name was given locally because it seemed appropriate and yet travellers found it informative, whether it was given locally but with the needs of travellers in mind, or whether it was given by the travellers themselves.

Take the name strät-tūn (see chapter 3), and suppose these places had facilities for overnight halts, were they so called by travellers because they were the ones offering facilities or were the names given by the inhabitants as an advertisement of the services they had to offer? Or take the geläd names (see chapter 4), were these given locally because the road that flooded in periods of prolonged wet weather was the most distinctive characteristic or was it given by road-users frustrated by the delays? How about the draeg names? Drceg is rarely combined with any elements other than tün or cot (see chapter 5). If they were really places where travellers (and local people) could get assistance, were they named by some higher authority using the term in a general sense, applicable to a variety of places with the same function? The fact that they are on important routeways and rarely elsewhere hints at some overall policy, and yet it is not impossible that the names were initiated by travellers who could have referred to these settlements as places where help could be found by using the terms draeg-tün and drag-cot, or yet again that the local inhabitants could be advertising their services.

The case of the cumb-tüns may be rather different. These settlements in hollows (coombes), often in view of ridgeway routes, do not seem to have had a particular function or service to offer (see chapter 7). They appear to have been no more than a useful landmark on a long journey: maybe a viewpoint where one habitually paused for a rest, or where one might meet travellers coming from the other direction. It would be easier for non-locals to refer to it as 'cumb-tün' 'village in a hollow' than ' $\mathrm{X}$ 's cumb' or some other 'element + cumb', because one did not then need to know the full name, only the general term for that kind of location. This would be fine if there were few cumbs locally but in a countryside full of cumbs it would not be so helpful. For instance, there is a line of coombes in the chalk escarpment south of Shaftesbury DOR, containing settlements called Compton Abbas, Fontmell Magna, Sutton Waldron, Iwene Minster, and one with no settlement. Why was one of these named cumb-tūn and how was the traveller to know which one? Perhaps the traveller needed to know further landscape clues. In the case of the cumb-tüns the perceptions of travellers seem more likely to account for the name than that villagers in many different places could have agreed that a cumb by a road should be called 'cumb-tūn' rather than 'element + cumb' (which would be normal elsewhere), or that a higher authority should find it worth distinguishing these settlements with no particular function by using a 'topographical element $+t \bar{u} n$ ' name. There remains the problem why some elements, halh, höh and scelf, so often are combined with tūn. They do not seem to be associated with routeways, and their function, if they had one, is unknown.

\footnotetext{
${ }^{90}$ In fact Worcestershire has many of these names, but they are minor names and therefore do not appear in DEPN, another indication that this data is only a rough guide to the situation. None of the methods of assembling data for this exercise gives reliable results. The method used is the least unsatisfactory. Actual numbers are not always accurate but the relative numbers are approximately right
} 
The way in which weg settlements came to be named is even more of a conundrum. The evidence assembled in chapter 3 shows that weg, especially in major names but also in most settlement names, was almost always used of steep roads, although occasionally of very muddy ones. However, on long routeways such as the Fosse Way and Icknield Way the gradient was variable, and local tracks, often within estates and with no weg-named settlements on them, might be of any gradient. If the name was given by local inhabitants there would have to have been a countrywide recognition that a settlement on a steep (or rarely a difficult) road might be called -weg, but that one on a gentle slope, as so many were, might not. The same caveat would also apply to people in neighbouring settlements naming the place - they too would have to have such an understanding. The chances of a higher authority choosing to use such a place-name seem slim: it was not a general term for a specific function or activity such as the functional tüns, like strāt-tūn or $d r c e g-t \bar{u} n$, seem to have been: unless they had local knowledge, how would they know which roads were sufficiently steep to be called weg and how would they select which few of those hundreds of steep tracks to call 'element + weg'? A variety of specifics described the local features of a particular weg be it stony, green or broad. Wegs would seem to have been named by those familiar with the road. A steep road was of concern to one group of travellers - the carters and waggoners - because of the dangers involved, especially going downhill. These are the people who would have exchanged information about the routes that they used and who would have warned one another about certain roads, and who could have used the term weg in that context. Among themselves they might have called the settlements most closely associated with that stretch of road 'weg', regardless of whether or not local people used some other name for the place. As has been noted, some places did have more than one name, and it was suggested that the one most widely known would come to dominate in the end.

This discussion has focussed on names that are to be found by routeways. There are a great many others whose origins are just as obscure and which may have originated in ways other than those mentioned here. It is rarely possible to pinpoint the origin of a name, but it does seem likely that different groups of names originated in different ways, sometimes from local people, sometimes as a result of travellers exchanging information, and sometimes from a higher, more distant body wanting to use a generic term for a specific attribute. These are only suggestions and they may be modified as other name-groups are studied. ${ }^{91}$ The point is that the names exist and can be used to extract information about the extent of the early medieval routeway network.

In conclusion, the traveller has to take into account many factors when choosing a route. Without maps and probably illiterate, one of the most helpful strategies would be to commit to memory the names of the places in the order that he or she would have to pass through during a journey. Names that described the roads and the crossing places themselves would be particularly helpful and therefore be easier to remember. It is suggested in the following chapters that there were other corpora of place-names denoting a variety of facilities helpful to long distance travellers - facilities such as water supply, lodgings and roadside assistance. Where these corpora almost invariably occurred by important roads but not elsewhere (roads defined, as a starting point, as those shown on the O.S. Map of Roman Britain) they might be used to distinguish between those roads which were being regularly used by long distance travellers from those used only locally or which had fallen into disuse.

\footnotetext{
91 There is a useful discussion in Hough, 'Commonplace', pp. 100-120, in which the origins of a wide range of name types are considered.
} 


\section{METHOD}

The basic idea behind this study is that, if certain corpora of place-names known to be closely related to route ways are plotted on a base map showing the Roman road system of England, some of the roads that were in use in early medieval England will be picked out by having strings of these names along them; other, non-Roman, roads can also be identified and added so that a picture of the main network can be deduced. Only the most important routes are under consideration. In fact the study is much more complicated than this in its execution.

Taking the roads first and recapitulating on the discussion in chapter 1 : it is notoriously difficult to date the origin of roads or to say when they were actively in use, but fortunately it is known that the Roman roads were built between the first and fourth centuries $A D$, and most of the more important and well-built ones have been recognised and mapped. Most of these roads would have been visible to the early Anglo-Saxons as lines in the landscape, with the aggers above the general ground level (as along Ackling Dyke, M 4, even now), and maybe with the paved surfaces showing if they were still being used, and not obscured with vegetation nor foundered in muddy places (even today part of the Roman road, M 160, over low-lying, oft-flooded Otmoor, M 160, is still a clearly raised bank serving as a footpath). The visible remains of these roads in the landscape would have been much better some fourteen or fifteen hundred years ago, and so it is likely that the early Anglo-Saxons saw these roads being used and followed suit themselves. In theory there was this basic network of well-made roads available for use by the early Anglo-Saxons; in practice it is likely that some of the routes had deteriorated too much to be very useful as trackways. This study aims to identify those that were in use.

In addition to the Roman roads there must have been numerous local tracks serving village communities and some long-distance tracks used by traders and other travellers. The most important and plausible of the latter are shown on the O.S. Map of Roman Britain (4th ed.). ${ }^{\prime}$ For the purposes of this study (especially the measurement of 'proximity to roads'), the roads shown on this map are deemed to have been recognisable, though not necessarily used, by the Anglo-Saxons. Approaching the road problem in reverse, it is possible to eliminate many roads shown on modern maps as being post-seventeenth century creations (motorways and bypasses are obvious examples) by comparing them to early O.S. maps or other comprehensive, reliable maps. There is, therefore, a period between the departure of the Romans and the publication of the first road maps when the road network is imperfectly known. There would be more roads in use by the long-distance early medieval traveller than just the Roman ones, but not necessarily in the same numbers as shown by Morden, nor along the same routes in some cases. ${ }^{2}$ The two valuable sources of information about roads from this intermediate period are the Matthew Paris map of about 1250 , and the Gough map of about 1360, which are described above (p.7). The routes depicted were clearly important by the fourteenth century. If strings of place-names indicative of a route-in-use appear along one of these routes, it suggests very strongly that the route was being used. Ogilby's road-map atlas of 1675 , though somewhat later, is so wonderfully detailed that it can be used to determine the exact route between two places. Sometimes these routes can be shown to go through otherwise seemingly isolated places indicative of a road-in-use. This is further discussed in Chapter 9 Synthesis.

\footnotetext{
${ }^{1}$ See last page of the Appendix for a map of key names and locations

${ }^{2}$ See pp. 7-8.
} 
The place-names to be used as indicators of routes-in-use must be carefully chosen. The selection of the material falls into three parts. Firstly, which corpora are to be chosen, and within the corpus which examples are to be included? Should, for instance, all the examples

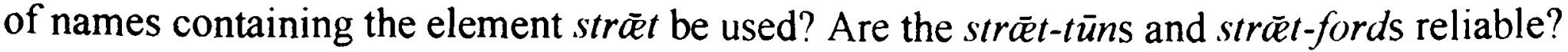
Should examples of strët which are not compounded with any other element be used?

Secondly, in choosing the elements to use it is obvious that those referring to roads, tracks and river crossings should be investigated, although not necessarily used in the end; some may be too uncommon to be useful (e.g. lanu, 'lane'), and some may refer only to very minor tracks (e.g. stig, 'upland path'). When considering water transport the four landing-place terms, port, hyth, stoeth and stoth, need to be investigated, as well as the terms for man-made water-ways: läd and skurthr. By themselves these groups are not sufficient to determine the communications network, but fortunately there are other place-names that are regularly found by routeways. Most of those which appear in chapters five, seven and eight were found by chance. The main exceptions were calde-cot and wĩc-häm, suggested by earlier authors, and gräfe-tūn and denu-tün, deliberately investigated. These serendipitous discoveries can be made when all the examples of an element have to be pin-pointed on 1 inch or 1:50,000 O.S. maps; these searches for precise locations can reveal other features that appear repeatedly near the place-name in question: this is how a possible link between or $a$ and Roman roads and ancient tracks was uncovered. In addition a familiarity with local examples and noting any common characteristics they have may lead to identifying further examples: knowing that Drayton St Leonard and Draycot OXF were both on the flood-prone Thame at points where the river was crossed by a Roman road (M 173a), it seemed worth finding out if other Draytons and Draycots were in similar situations. Realising that various elements not apparently associated with routeways do sometimes correlate with them it seemed appropriate to plot any other potentially interesting element on both a relief map, and a Roman roads map. The correlation of the terms cumb-tün and mere-tūn with roads emerged this way, but such mapping does not always yield such worthwhile results. Therefore, suspecting that there might be other functional tüns relating to routes, the grāefe-tūns, denu$t \bar{u} n$ s and $\bar{e} a-t \bar{u} n s$ were investigated with positive results, but the results for halh-tūn and hōhtün were negative. ${ }^{3}$

Thus the selection of elements, although partly for obvious reasons, has also been partly a result of serendipity; many place-names relating to route-ways have been discovered accidentally during my two decades of investigation; there may be others yet to be identified.

Thirdly, having decided which elements or compounds to study, the next question was how to assemble reliable corpora and to ensure as even a coverage over England as possible. One of the constraining factors is the existence or not of reference books. This is one reason for excluding, with rare exceptions, any examples from Wales or Scotland. Ekwall's Oxford Dictionary of English Place-Names provides a good, even coverage of all England. Watts' Cambridge Dictionary of English Place-Names was published towards the end of the study. Indeed, these two are almost all that is available for Somerset and Suffolk; other counties have been wholly or partly covered by the English Place-Name Society's county volumes and by other reputable authors, but this coverage varies considerably in depth. To use the very minor names of, say, Gloucestershire or the West Riding of Yorkshire, but to be unable to do so in, say, Buckinghamshire or Bedfordshire, would give a misleading impression of the density of travellers' terms from place to place. For that reason the names chosen were, in most cases, those of settlements, since these were the ones most likely to be included in the least detailed volumes. It is more likely that travellers would know the names of settlements than the names of minor landscape features, although, of course, they would know the bigger

\footnotetext{
${ }^{3}$ Functional tüns are discussed on p. 12
} 
features, such as major rivers like the Thames or substantial hills like the Mendips or Malverns. One cannot be sure that all the place-names included and referring to present-day settlements were settlements in the early medieval period: the ones with habitative endings, mostly tün, would have been, but it is quite possible that some of the other purely topographical names were not. This would be especially true of $\overline{o r a}$, and may well have been true of such terms as weg and ford at an early stage.

Another factor to take into account is the date at which the place-name is first evidenced. This is almost certainly well after the name was coined, and of that we have no knowledge. Any place mentioned in DB would have been in existence in the time of Edward the Confessor, and therefore easily falls into the early medieval period (taken as being from the end of the Roman period to about 1100); these names can be used as evidence for routes-inuse. Some places were the subject of Anglo-Saxon charters and these usefully provide an earlier date. The names that appear in the boundary-clauses of these charters usually refer to small landscape features, and have only been used very sparingly. Della Hooke has used this material to trace local routes, and they are best fitted to elucidating local topography, not country-wide features.

Many places are first mentioned later than DB, especially in northern counties, although they may have been in existence long before: for instance, 10 of the 43 cumb-tüns do not appear until after 1086, but are almost certainly Anglo-Saxon coinages. Therefore, a distinction has to be made between those names which were definitely in use in the early medieval period, and those which were first evidenced after DB and which we cannot be certain existed then. This means that both networks need to be shown on the final map. Places which have not appeared in any records by 1500 were, with rare exceptions, excluded. The English language has evolved during many centuries, passing from the Old English of the Anglo-Saxon centuries through Middle English to the Modern English of the present day. This could involve a shift in the meaning of some terms. In order to minimise any untoward effects of this shift, it is best to exclude places which have not appeared in the records by 1500 .

It was said at the beginning of this chapter that the basis of the thesis was that certain corpora of place-names are consistently near or on Roman roads and certain other old tracks. This is an inexact statement. What does 'consistently' mean? Is it 'often', 'usually', 'invariably'? How close is 'close'? These two variables need to be measured. A method of doing this is by using the chi-squared test which is described in detail in Section 1 of the Appendix. Briefly, it compares the proportion of settlements in any corpus (within $\mathrm{x}$ miles of a route shown on the O.S. Map of Roman Britain) which actually occurs with that one would expect if the distribution was random. This gives the probability of any such distribution occurring. If the probability is very low, then there is a significant correlation between the settlement name and the road system. For instance this method shows that in the strēt-tūn corpus there is a very close and significant relationship with Roman roads, but in the case of the ãc-tün corpus there is not (see fig. 1.16).

It is recognised that settlements have sometimes appeared, disappeared or shifted, and that the sites of today's settlements may not be the same as those in Anglo-Saxon times. The likelihood is that the shift was normally within the bounds of the estate. Where the placename refers to a large landform such as a dūn or a denu, even with a shift of some hundreds of yards, the settlement name would still be appropriate. Settlement names referring to smaller features may be less appropriate after any shift in site of this magnitude; however, in some cases, such as bröc, burna, welle or mere, any shift is likely to be limited by the need to remain close to the water supply. The case of strēt-tün, described below, suggests that any shift that has occurred in this group has had little or no effect on the measurement of 
proximity to Roman roads. For present purposes it has been assumed that this will also be true of other categories of name.

To test if this method (the chi-squared test) of measuring proximity of a place-name type to the roads on the O.S. Map of Roman Britain yields good results, the element strüt was chosen. It has long been recognised that strët denotes a Roman road, and that settlements incorporating the element into their names were almost always close to Roman roads. The result of the calculations should be a foregone conclusion: there should be a high degree of correlation. If the method works well for strät, in spite of possible settlement drift, and in spite of some uncertainty as from which part of today's settlement the distance to the road should be measured, then the method should work for other place-name categories too.

Preparing the corpus for analysis involved collecting data for each place, as illustrated in fig. 2.1, strīett-tün. The list was compiled from DEPN, the EPNS county volumes and other works listed under County Abbreviations, pp. v-viii. When ascertaining the grid reference a problem arose in deciding which part of the settlement to choose as being the most likely site of the original settlement. In most instances the church was chosen, and, if there was no church, then a central road junction or manor house. The church was chosen because it is likely to be the oldest surviving building, and was sited in the main settlement at the time it was built (of course this need not necessarily be so, but it seemed the best option when many hundreds of examples throughout the study needed to be dealt with). To check whether or not this was a workable option, an idea of the age of the parish church in each strēt-tün was gleaned from the entries in Pevsner's Buildings of England series, or in VCH volumes if they existed (fig. 2.1). The age of the church was based on the period of the earliest surviving part of the building, but not on moveable items such as fonts. Most of the nineteenth and twentieth century churches were urban ones, built to cater for the rapidly increasing number of townsfolk. The outcome was not very helpful because 14 of the 43 places had no Church of England church, and in a further five there was either no known Roman road nearby or no data about the age of the church. Of the 24 usable examples 18 churches were within a quarter of a mile, ( 400 metres) and none were more than one mile away. There was very little difference between the distances of early (pre c.1400) and modern (nineteenth or twentieth century) churches from Roman roads: in both cases about two-thirds were within a quarter of a mile. The findings are generally supportive of the idea that the old heart of any village called strät-tün was likely to be on or very close to a Roman road - at least they do not contradict the idea. Of the 13 hamlets with no church, the adjudged centre of the hamlet was within a quarter of a mile of a Roman road in seven cases, and more than one mile in only two: results almost as good as those for settlements with churches. It seems that even if the site of the original settlement has drifted over the centuries, or if the settlement has changed in form (for instance from being dispersed to being nucleated), there is still a close relationship between the settlement and the Roman road: sufficiently close for a statistical test to highlight the link.

Having established that measuring the distance from the church or major road junction in a strōt-tün to a Roman road is a reasonable, pragmatic way of ascertaining the 'closeness' or proximity of a settlement to a Roman road, the three tests listed in the Appendix Section 1 can be applied (see vol. 2, p.1). 
a) Test 1 . Observed and random distributions.

Observed distribution compared to random distribution of $s t r \bar{e} t-t \bar{u} n s$ at various distances from a Roman road.

\begin{tabular}{|c|c|c|c|c|c|c|}
\hline \multirow{2}{*}{$\begin{array}{l}\text { Distance from } \\
\text { Roman road }\end{array}$} & \multicolumn{3}{|c|}{ Observed distribution } & \multicolumn{3}{|c|}{ Random distribution } \\
\hline & No. within & \% with & No. beyond & No. wi & witl & beyond \\
\hline $0-1 / 4 \mathrm{mile}$ & 23 & 62.16 & 14 & 1.48 & 4.0 & 35.52 \\
\hline $0-1 / 2$ mile & 28 & 75.68 & 9 & 2.96 & 8.0 & 34.04 \\
\hline $0-1$ mile & 32 & 86.49 & 5 & 6.1 & 16.5 & 30.89 \\
\hline
\end{tabular}

The table is made up of 37 examples because the two pairs (East and West Stratton, and Great and Little Stretton) and the triple (All, Church and Little Stretton) were counted as one each, since such qualifiers usually reflect the fission of an already-named unit.

A very high percentage of strāt-tüns is found within a short distance of a Roman road over $62 \%$ within a quarter of a mile, and just over $75 \%$ within half a mile, when, with a random distribution, only $4 \%$ and $8 \%$ respectively would be expected. Of the five places apparently more than one mile from a Roman road one, Stratton Hall SFK, is in the area of East Anglia where it is thought that such Roman roads as were built are unlikely to have left traces today; Stratton Hall is likely to have been very close to the hypothetical road that would have linked Combretovium (Baylham) to Walton Castle. Stretton en le Field LEI, Stratton Strawless NFK, Sturton Grange NTB, and Stony Stratton SOM, are not near any known Roman roads although as yet undiscovered roads may have been nearby. They are mapped in fig. 2.2

b) The dispersion graph

Test 2 , the dispersion graph, shows the clustering of strēet-tüns near to Roman roads very effectively (see fig. 2.3), with a marked clustering of points five-eighths of a mile $(1 \mathrm{~km})$ and less from a Roman road. The median value of three-sixteenths of a mile $(0.3 \mathrm{~km})$ is low. The inter-quartile range of half a mile $(0.8 \mathrm{~km})$ indicates a high degree of clustering around the median.

c) The chi-squared test. ${ }^{4}$

If test 3 , the-squared test, is applied to the figures set out above, the figures show an extremely high probability that the distribution of $s t r \bar{e} t-t \bar{u} n s$ with respect to Roman roads is not a random one.

The formula for the chi-squared test is:

$\chi^{2}=\sum \frac{(0-e)^{2}}{\mathrm{e}}+\frac{(0-\mathrm{e})^{2}}{\mathrm{e}}$

Substituting the values from the table above we get:

For up to 1.0 mile (1,600 metres)

$\chi^{2}=\Sigma\left(\frac{32-6.11}{6.11}\right)^{2}+\frac{(5-30.89)^{2}}{30.89}=\Sigma 109.70+21.70=131.40$

\footnotetext{
${ }^{4}$ See Appendix Section 1 for a more detailed explanation and key to abbreviations
} 
The chance that $86.49 \%$ of strēt-tüns randomly distributed should fall within I mile of a Roman road is much less than 1 in 1,000. Unfortunately, for distances of less than 1 mile the results are unreliable, but the chances are even less than 1 in 1,000. The distribution is very unlikely to be random.

It has thus been shown that there is a very close correlation between Roman roads and settlements called strāet-tūn. This demonstrates local awareness of Roman roads as distinctive features, but not necessarily that those roads were in general use in and beyond the settlement at the time of naming.

However, many Roman roads are still in use today, sometimes along the exact route and sometimes with minor deviations, although close enough for it to be evident that the line of the road was recognised and used as a route. It is more likely that the line of such a road would have been known and used ever since it was built than that the route had become disused, and completely lost to view, its existence unrecognised, and then a new road had evolved along the old line quite by chance. It is not impossible that some lines were still known and perhaps used as boundaries but not route-ways, and were later re-instated as a route-way, but this seems less likely than the first option. If the lines of the Roman roads in the neighbourhood of each strät-tun are examined it will be found that in the late twentieth century 23.5 of the 43 were along A roads, one along a B road, 11.5 along minor roads, one along an un-metalled road and one along a bridle way (fig. 2.1) One Roman road did not survive and in four cases no Roman roads have been identified in the vicinity: i.e. 36 $(83.72 \%)$ of the roads were metalled today, or $37(88.37 \%)$ survived if tracks are included. With this high survival rate, it seems probable that the Roman roads going through strēt-tüns were in use at the time of name-coining, and that most have remained so ever since. Overall, the survival rate for Roman roads remaining in use as roads, tracks or footpaths is lower around $64 \%$.

The foregoing examination of strät-tīn with respect to Roman roads shows that it is normally safe to use the distance between the church or major cross-roads in the settlement and the Roman road as a measure of proximity; that the very high proportion of strēt-tūns within half a mile of a Roman road is extremely unlikely to occur by chance, and therefore that the Roman road with which the strāt-tūn is associated has probably been in continuous use since Roman times. The four which are apparently not by Roman roads are more likely to be so because the Roman road is not now known or even traceable, rather than because a road did not exist in the first place.

The main argument will now be set aside to consider the other settlements incorporating the element strēt. The one most obviously connected with Roman routes is strët-ford (see map: fig. 2.5). Two of them survive only as the names of fords (now bridges), and either there is no nearby settlement or it has a completely different name. There are 20 settlements called strät-ford: in two cases they are paired with one on each side of the ford: Stratfordatte-Bow MDX with Stratford ESX; and Old Stratford NTP with Stony Stratford BUC. Stratford on Avon WAR and Old Stratford WAR, on the same bank of the river, refer to the same crossing, as do Stretford and Trafford LAN. This means that there are 18 crossings called strēt-ford, of which 16 are on Roman roads and one, Stratford SUR, is on the A3 London to Portsmouth road; Margary wonders if this proto-A3 is Roman, and further if M $151^{5}$ from Rowhook intersects with it at Stratford Bridge: at the other, Stratford St Andrew SFK, there is no known Roman road. ${ }^{6}$ Fig. 2.4 shows that, excluding Stratford St Andrew, the churches or centres of the hamlets are, in all but one case (Stratford-sub-Castle WLT), within a quarter of a mile of a Roman road. All but Stratford-sub-Castle are within

${ }^{6}$ Margary, Roman Roads, 1, p. 235. 
half a mile of the ford; sometimes it would have been unwise to build any closer to the ford because of ill-drained ground or susceptibility to flooding. In all 18 cases the roads have remained in use at least in part, a high proportion of them being A-class roads. In the case of Water Stratford about a mile of the Roman road south of the ford has been disused since before the coming of the railway, and in the case of Stratford GLO, the Roman road north only survives intermittently. A similar pattern of survival and continued use of Roman roads in the vicinity of strcett-fords emerges as that exhibited by the sträet-tüns.

Occasionally sträet is combined with other elements (see list: fig. 2.6 and map: fig. 2.5). There are eight examples of strēel-lēah, all but one evidenced by DB. Six are on or within three-eighths of a mile of a Roman road. Strettelegh, a lost place in Tabley Superior CHE, is first evidenced in 1316, and as a Roman road runs right through the middle of the township/parish it would have been within one and a quarter miles of the road. Strelley NTT, however, is six and three-quarter miles from the nearest known Roman road. There is a good survival rate of these Roman roads: six remain in use, and the seventh is disrupted by Sutton Coldfield Park.

There are four examples of strēt-feld: three of them, Stratfield Mortimer BRK, and Stratfield Turgis and Stratfield Saye HMP, are close together in a large area south of Reading where there are ten adjacent parishes called - feld - probably a wide expanse of rough pasture. The Stratfields were located where the Roman road from London to Silchester ran through the feld. They are up to 2 miles from the road, which is an acceptable distance having regard to the nature of a feld and that the name may have originated as the name for a big estate straddling the Roman road. Streetfield Wood SSX (not a settlement) abuts a Romanised ridge-way (Track 2 ) in the Weald. ${ }^{7}$ In all four cases the Roman road survives even if only as a rough track.

Stre(a)tham occurs two or three times: Streatham SRY on a surviving Roman road, and Stretham CAM, also on a Roman road but which only survives to the south, are from OE $h \bar{a} m$, a 'homestead'. Streatham, SSX, is a quarter of a mile from a disused Roman road (the present route arcs to the south to make an easier crossing of the Adur at Bramber). Since the only available spellings are twelfth century and the settlement is by a river, it is not possible to tell whether the second element is häm or hamm.

strāt is combined with other OE place-name elements, but there is only a tiny handful of examples of each, as can be seen from fig. 2.6 As indicators of Roman roads these cases seem less reliable. However, some of the features named, like the halh of Strethall ESX and the bröc of Stradbroke SFK, are large. A settlement could be in a hollow (halh) through which a Roman road ran, and still be further from the road than a tün or a häm would be. In the case of Stradbroke, the nearby stream $(b r o \bar{c} c)$ falls into the river Waveney at the point where M 35 reaches the river at Weybread/Needham, hence its name 'Street Brook'. Any settlement taking its name from the stream would not necessarily be close to the Roman road too. Stradishall SFK, though not by a known Roman road, is only one and a quarter miles from Wickhambrook, and wich-häms are strongly indicative of substantial Roman remains and accompanying roads. Sträet combined with elements other than $t \bar{u} n$ and ford shows a good correlation with Roman roads which are still in use. Where the link is not as good as one would wish there are four possible reasons:

i) There was no Roman road in the locality to start with.

ii) There was a Roman road but it has not been located in modern times.

iii) The second element might refer to a large topographical feature by or on a Roman road; the settlement may have been named from the feature but not situated on a part of it that is close to the road, for example Stradbroke.

${ }^{7}$ I.D.Margary, Roman Ways in the Weald (London, 1948), p. 262. 
iv) There has been a shift in the site of the settlement.

Given the close relationship between strüet names and Roman roads the first option is not a good one and should probably be discounted.

Sträet occurs frequently on its own as a simplex name or as the second part of a twoelement name. Great care is needed in dealing with these names, because, by the later medieval period, 'street' was often used to describe straggling villages in areas of late woodland clearance. Such places as Exlade Street in the Chilterns and Paley Street east of Reading are instances. They only relate to Roman roads occasionally by coincidence. The problem here is that we do not know when the name was coined. If it appears in DB, it existed by 1086 and most probably by 1066 . If it first appears in the record post-DB, say 1250 , we do not know if it was coined in the period between $D B$ and 1250 and should be treated as a later-named place, or whether it was coined pre-DB but does not appear in any surviving record until some two centuries later. It is not, therefore, possible to say whether the simplex strüts first evidenced post-DB were named using the later sense of ströet, or whether they were named pre-DB using the old sense of strät. This is why the simplex sträts are not reliable as evidence of a Roman road in use, as we do not know to which category they belong. The problem is illustrated by an examination of the simplex examples which shows that there are six examples recorded by DB, all of which are on or within a quarter of a mile of a Roman road. Sixteen are post-DB, the earliest in 1240; of these, eight are too insignificant to appear on the 1:25,000 map and their distances from a Roman road have only been given as a range of values. The sites of the other eight are known. Six or seven of the sixteen are within one mile, and nine or ten more than one mile from a Roman road. It is clear that by this time strāet as a simplex term is an unreliable indicator of a Roman road and should not be used as such (see fig. 2.7).

In Lordine Court SSX (Lordistret DB) strët is the generic. It is one and one-eighth miles from a Romanised ridge-way in the Weald, and being the only one in its category has little effect on the argument.

The foregoing examination has demonstrated that sträet is generally a reliable indicator of a Roman road that was in use at the time of naming. There is evidence that many were named by the time of the Domesday Survey, and even those appearing in the written records at later dates could well have been in existence much earlier. Strät-tün, strēet-ford and other names where strāet is the qualifier are particularly good indicators. Sträet on its own is reliable if evidenced by $\mathrm{DB}$, but late occurrences of the term did not necessarily refer to a Roman road and should be avoided. The distance between the church and the Roman road gives a satisfactory measure of the proximity of the settlement to the Roman road in most cases.

We can now return to the original argument. Since it has been shown that the strēet-tüns even today have a very close correlation with Roman roads, the method can be extended to other groups of place-names. Inevitably, among those which are closely related to the major Roman roads and ancient tracks (as shown on the O.S. Map of Roman Britain) there will be a few examples which are distant from these routes. This is because these were not the only important routes in use. These few, seemingly aberrant, examples are important in helping to identify other old routes in use, but the process must not end in a circular argument. This can be avoided in two ways. Firstly, there may be other evidence for existence of the route: it may be a Roman road known but not on the O.S. map, such as the one from Dorchester-onThames to Fleet Marston and on to Irthlingborough; it may feature in an Anglo-Saxon charter as a herepath or perhaps a strcet (the latter are not necessarily Roman roads, but may be relatively 'main' roads); ${ }^{8}$ or it may be one of the downland ridgeways referred to in charters Alternatively, one can work backwards from the excellent map evidence in Ogilby's

\footnotetext{
${ }^{8}$ Hooke, Landscape, pp. 121, 145-7.
} 
Britannia of $1675,{ }^{9}$ which names the places that the main roads of the seventeenth century passed through. Some of these routes appear on the Gough Map of c. $1360,{ }^{10}$ this is a much less detailed document, but where the succession of places that a route goes through on the Gough map is the same as that on the Ogilby strip-maps it is reasonable to suppose that the roads used were much the same. If, then, a series of route-indicative place-names dating back to DB also occurs on one of these routes, the implication is that the route was in use in at least the late Anglo-Saxon times. Other routes known to be old are the salt ways emanating from Droitwich and the Cheshire wiches; then there are the miscellaneous routes referred to in medieval documents, a number of which are listed in the county volumes of The English Place-Name Society under 'Road Names'. These sources can indicate the existence of an old route but will not necessarily tell us whether it was in use in the early medieval period. This is where the place-names come in, particularly those recorded in DB or earlier. Where these occur strung out along a known or suspected early routeway, and especially where there is a variety of different names (for example, a strēt-tūn followed by a mere-tūn and a drag-cot), one can be almost certain that that route was in use at the time that the names were coined i.e. some time in the Anglo-Saxon period. Not every place existing in the late eleventh century was recorded in $\mathrm{DB}$, and so there are many route-indicative place-names first evidenced after the Conquest. They can be used in conjunction with the DB and pre-DB names to identify routes in use, although it should be borne in mind that routes (both Roman and others) change in importance as trade develops or settlements change in status. Hoskins' essay on the growth of Market Harborough and its effect on the local road system is a nice example of this process. ${ }^{11}$ Routes may be abandoned when a bridge over a large river collapses, or become important when a new bridge is built. The post-Conquest recorded names need to be used with care when identifying pre-Conquest routes.

With this methodology established, other place-name corpora can be subjected to it, to test whether or not they correlate significantly with the Roman roads and ancient tracks shown on the O.S. Map of Roman Britain; where they do, this indicates that the road was in use at the time of name-coining. Those names in each corpus which are not close to the routes on the O.S. map, may be suspected of being close to some other old route.

Investigations may reveal a link with minor or recently identified Roman roads, salt ways, routes on the Gough or Ogilby maps, or other routes suspected of being old. In this way the bare bones of a network, exemplified by the Roman roads which are known to have existed (even if not as roads-in-use) at the start of the Anglo-Saxon period, can be filled out by other routes whose dates of origin are not known. From the place-name evidence alongside them, these non-Roman routes can be assumed to have been in use in the early medieval period. In this way evidence for a route first documented by, say, the Gough map of c. 1360 can be pushed back at least three centuries. Although the whole process of identifying these old routes relies very heavily on using Roman roads in the first place (because they are datable), it is just the first step in identifying the rest of the network about most of whose origins little or nothing is known (see chapter 9 for further details). The other place-name elements referring to route-ways (e.g. weg, path, stig) cannot be subjected to the chi-squared test because they refer to routes other than Roman roads; these form the subject of the next chapter.

\footnotetext{
${ }^{9}$ Ogilby, 'Britannia'.

${ }^{10}$ Brian Paul Hindle, Medieval Roads (Princes Risborough, 1982), pp. 17-20

${ }^{11}$ W.G. Hoskins, Provincial England (London, 1963), ch. 3
} 


\section{CHAPTER 3}

\section{ROAD TERMS}

There are six place-name elements in frequent use which refer to roads: strüet, weg, pieth, stīg, anstig and herepceth herestrēet. A few others occur; OE lanu is too rare to be useful, and ON gata is mostly used of roads or very minor features, not settlements.

It would be helpful to travellers to know what sort of road they would be travelling along. Strēet was used of Roman roads; the Anglo-Saxons would associate a name incorporating this element with a direct and generally straight road and one which was (or had been) well constructed with a firm surface of stones and gravel laid on a raised bank or agger. The correlation of strāet with the Roman road system was discussed in the previous chapter; the next element to investigate is weg.

\section{a) $W E G$}

Weg occurs in about 117 settlement names that appear on the 1:25,000 maps and are evidenced by the year 1500 . Of these 20 are recorded in DB and a further three are parishes. Thirty-five more are first evidenced between DB and 1250, and 57 between 1251 and 1500 (see fig. 3.1). The distribution, though countrywide, is predominantly western, in the hillier regions of England (see map: fig. 3.2).

Smith's definition 'a way, a path, a road' covers both settlements and a great variety of track-ways, and is perforce not very precise. ${ }^{1}$ Gelling describes it as 'the general Old English term for a road ... (it) appears to have had no specialised sense. It is most common as a qualified generic in the names of roads such as Icknield Way, Fosse Way and the ubiquitous ridgeway. It is not common in settlement names'. ${ }^{2}$ Kitson (unpublished), referring to charterboundary examples, describes it as 'the ordinary Old English term for a road'. ${ }^{3}$

As weg was used in a variety of situations (settlement names, names of local and long distance tracks, charter boundary points) it is helpful to consider their distribution and nature in more detail.

Concerning distribution: the term was widely used throughout England, although infrequently in the Danelaw. It was often used of local tracks - many are listed in the EPNS county place-names volumes. ${ }^{4}$ It was frequently used in charter boundaries. Kitson notes 782 features called weg. It was evidently the ordinary English term for a road as Smith, Kitson and Gelling observed. It was not restricted to any particular region by reason of dialect, nor was it restricted by reason of topography, since it was found in both hilly and relatively flat areas. However, this is not the whole story because it is evident that the settlements incorporating the element weg have a more restricted distribution. The relief map: fig 3.2 shows them to cluster in hilly areas: even at this small scale it suggests that weg-named settlements are associated with the margins of the uplands and not with patches of flatter land such as the Somerset Levels or the Vale of Berkeley. This being so suggests a link with pronounced slopes. (See below).

Concerning the nature of the settlements: strät took on a different meaning over the centuries as mentioned above (p.28) changing from one referring to a Roman road to one used of settlements strung out along roadsides. ${ }^{5}$ Are there any settlement types (e.g.

\footnotetext{
${ }^{1}$ A.H. Smith, English Place-Name Elements (2 vols, Cambridge, 1956), 2, p. 248.

${ }^{2}$ Gelling and Cole, Landscape, p. 95.

${ }^{3}$ Peter Kitson, Guide to Anglo-Saxon Charter Boundaries (unpublished), section 6.40

${ }^{4}$ PN. CAM p. 305; PN. CHE 5.ii, p. 381-2; PN. ESX p. 593; PN.GLO 4, p. 184; PN. RUT p. 393; PN. WOR p. 393; PN. YWR 7, p. 266

${ }^{5}$ Gelling, Signposts, p. 153
} 
nucleated, polyfocal, linear, dispersed) particularly associated with weg? The list in fig. 3.1 includes 44 examples of the term in Farm, Court, House names which are likely to be just small clusters of buildings. Many others, especially those in Devon, also fall into this category - in essence they were no more than hamlets. The settlement morphology of the DB and parish names in weg was analysed from O.S. maps, but as these only go back to the early nineteenth century, one cannot be sure that the early medieval settlement was similar in layout. Out of the 23 examples, 12 are farmsteads or small hamlets; three are nucleated or polyfocal; two have been modified by emparkment or industrialisation (Stanway, GLO; Whaley Hall CHE); five are linear villages: Broadway SOM; Broadway WOR; Hanwell OXF; Barkway HRT; Wayford SOM and marginally Radway WAR. In the cases of Broadway WOR and Barkway HRT being on routes busy in recent centuries would have encouraged linear expansion, and there is no knowing if they were linear in early medieval times. However, it does seem clear that most weg settlements were small and that the typical morphology was that of a hamlet, as it is likely to have been through the centuries.

If the concentration of weg in settlement names towards the west is not to be explained by a dialect usage nor is weg to be associated with a particular morphology, can it be associated with the terrain?

The possibility of an association with slopes, manifest as gradients on routeways, was examined. There would be good reason to want to know, or have warning, of a steep gradient because they could be dangerous for wheeled vehicles (a useful discussion will be found in Davies). ${ }^{6}$

Pedestrians, riders and trains of pack-animals can negotiate steep slopes in comparative safety. In England before the advent of canals, railways and motor traffic, pack-trains were responsible for moving large quantities of goods overland in regions where river traffic was impracticable. However, a draught animal could move a greater weight of goods by drawing it on a sled. This was comparatively safe, because sleds had a simple and effective braking system (a log lowered in front of the runners), ${ }^{7}$ but for animals drawing carts (two wheeled) or waggons (four wheeled), the nature of the road surface and its gradient imposed limitations on the routes that could be used.

The rolling resistance is the resistance to movement along a road caused by the contact between the wheels and the road surface. A smooth, paved or natural rock surface will offer less rolling resistance than a rough, gravelly or sandy one. It has been estimated that on a smooth surface the rolling resistance is $1 / 70$ the weight of the load and for thick gravel $1 / 16$. When going uphill, the draught animal will have to overcome both the rolling resistance and the force of gravity before it can move the load, and clearly a smooth surface is an advantage there. However, going downhill the force of gravity will act in the animal's favour and help to overcome the rolling resistance. Where the rolling resistance is approximately equal to the force of gravity, the animal and vehicle can descend safely. If the force of gravity is much greater than the rolling resistance the vehicle will gather speed of its own accord and without a good braking system may overwhelm the draught animal(s), causing an accident.

Alternatively, a windlass could be used to ease the load downhill. In the case of vehicles moving down a steep slope a smooth surface is the more dangerous; with a gradient greater than 1 in 70, gravity exceeds rolling resistance and safety begins to be compromised. With deep gravel a safe gradient can be as much as 1 in 15 . A useful compromise for surfaces of average hardness is to have a maximum gradient of 1 in 30 (or 1 in 20 if unavoidable in very hilly areas). Only on loose gravel could a vehicle descend a slope steeper than 1 in 20 safely. ${ }^{8}$ For anyone driving a laden waggon or cart, it would be important to know if there were any

\footnotetext{
${ }^{6}$ Davies, Roads, ch 8.

${ }^{7}$ Cyril Fox, 'Sleds, Carts and Waggons', Antiquity, 5 (1931), pp. 185-99.

${ }^{8}$ Davies, Roads, p. 79.
} 
steep, dangerous roads to descend en route. It is possible that settlement names in weg performed this function.

To test this hypothesis, 133 examples of weg referring to settlements were assembled and their gradients calculated where possible: this was done using the Provisional Edition of the O.S. 1:25,000 map. A number of problems were encountered:

i. Some examples of weg were lost places and had to be omitted.

ii. In some instances it was not at all obvious to which road or track a name referred.

Where the identity of the weg was in doubt the steepest part of any contending through-road was measured.

iii. The section of road measured needed to be long enough for gravity to have taken effect - in other words at least 100 yards; in practice the length measured was rarely less than 250 yards.

iv. Error creeps into the calculation because of the difficulty of measuring the horizontal distance accurately on a map.

v. An average gradient for a distance of several hundred yards may mask minor dips and rises which could be even steeper.

vi. The gradient as measured on the map is that of the ratio of Vertical Distance :

Horizontal Distance, marginally steeper than that encountered on the road which is given by the ratio Vertical Distance : Distance Travelled. However, these differences are insignificant compared to the errors arising from iv and $v$.

The system of measuring gradients has its limitations, and none of the gradients given can be considered wholly accurate. However, they are good enough to compare with each other

The gradients of wegs which have become settlement names were compared firstly with those of strōt-tün and strät + element, secondly with pceth, thirdly with weg used of trackways, and lastly with wegs used as charter-boundary marks.

The gradient measurements are shown on the fig. 3.3 and are illustrated on the graph: fig. 3.8. There is a marked clustering of values between 1 in 7 and 1 in 16 , the median value being 1 in 12.75. Eighty-six of the 91 usable examples (94.5\%) of wegs have a gradient of 1 in 30 or steeper - the steepest gradient desirable on surfaces of average hardness. Seventyeight of the $91(85.7 \%)$ are steeper than 1 in 20 - the steepest gradient tolerable in hilly areas.

For comparison with another route-way term, the gradients of settlements named strēt$t \bar{u}$ n and 'strōet + element' were measured ('strāet + ford' examples were omitted because of the topographical bias towards river valleys). The Roman engineers chose their routes to avoid unnecessary hills where practicable, but were not averse to steep hills where there was no ready alternative. In these cases the road might zigzag up the hill. The gradients measured do show a high proportion of very gentle gradients, $36(63.1 \%)$ gentler than 1 in 30 , and only $7(12.3 \%$ ) steeper than 1 in 20 . This is in marked contrast to weg (see figs $3.4,3.5$ and 3.8).

A further comparison was made with the gradients of path-named settlements (see figs 3.6 and 3.8). On the latter the North Country (DUR, NTB, WML, YOW) examples are in bold type. There is a north-eastern dialect form, peth, used of sloping tracks down steep valley sides, ${ }^{9}$ which biases the whole corpus towards a higher percentage of steeper gradients. Nevertheless, there is still a clear contrast between the relatively even spread of paeth gradients, with the higher proportion of gentle/level strēt gradients, and with the higher percentage of steep weg gradients, as shown by the following table:

\footnotetext{
${ }^{9}$ Victor Watts, A Dictionary of County Durham Place-Names (Nottingham, 2002), pp. 16-7.
} 


\begin{tabular}{|c|c|c|c|c|c|c|}
\hline \multirow[t]{2}{*}{ Gradient } & \multicolumn{2}{|c|}{ Weg settlements } & \multicolumn{2}{|c|}{ Strāet settlements } & \multicolumn{2}{|c|}{ Path settlements } \\
\hline & No.of e.gs & $\%$ & No.of e.gs & $\%$ & No.of e.gs & $\%$ \\
\hline 1 in 10 or steeper & 36 & 39.6 & 0 & 0 & 9 & 36 \\
\hline 1 in 20 or steeper & 78 & 85.7 & 7 & 12.3 & 13 & 52 \\
\hline 1 in 30 or steeper & 86 & 94.5 & 21 & 36.8 & 15 & 60 \\
\hline Less than 1 in 30 & 5 & 5.5 & 36 & 63.1 & 10 & 40 \\
\hline
\end{tabular}

A very much higher proportion of weg routes than of ströt or paeth routes have gradients greater than that normally considered safe for draught animals. It therefore would appear that to use a route whereon or whereby lay a settlement named weg could be hazardous for wheeled vehicles, especially going downhill, although it might be safe for pack animals, riders and pedestrians, whereas strōet has no particular connotations of gradient, and pceth only does so in its northern dialect form. Perhaps weg used in settlement names meant 'steep road', but then did the term weg as used for roads, tracks, and points along estate boundaries, but not settlements, refer to steep slopes or not?

The Place-Names of Cambridgeshire (pp. 18-33) lists many wegs referring to tracks, most of them first evidenced in the thirteenth century or later. There are, for instance, 14 parishes wherein there is a Broadway (this does not necessarily mean that there are 14 different examples of Broadway), 25 parishes with a Greenway, three with a Mereway, eight with a Portway, eight with a Ridgeway, 15 with a Smallway and 17 with a Woodway. In as flat a county as Cambridgeshire few of the parishes in question have any slopes as steep as 1 in 30 , so that even if the location of the weg is not known it can safely be assumed that the slope is gentle in almost all cases. In other hillier counties a higher proportion of wegs would have had gradients over 1 in 30 - in fact countrywide there would have been a wide range of gradients. The use of weg in this context does not carry an implication of steepness. Most of these types of tracks are short local routes giving access to nearby settlements, or to resources within the parish such as woods: they are rarely part of long-distance routes. For such long routes as the Icknield Way and the Fosse Way an average gradient would be meaningless and so they were not considered.

Weg is a very common term in charter boundary clauses: Kitson notes 782 different features called weg. ${ }^{10}$ The gradients of 41 wegs identified in Berkshire by Gelling and Hooke, ${ }^{11}$ and in Warwickshire by Hooke, ${ }^{12}$ were investigated, the countryside being sufficiently hilly for any correlation between weg and steep gradients to be noticeable. Many wegs were too short to have their gradients measured since they were crossed by only one contour or none at all, but it was evident from the surroundings that the gradients were not steep enough to cause problems (see fig. 3.7). In only two cases was the gradient greater than 1 in 10, and those for short distances only. Five were about 1 in 12, nine between 1 in 20 and 1 in 30 , and the remainder, 23 , had even gentler gradients. The countryside covered by these charters varied from the scarp slope of the Berkshire Downs through the rolling countryside

\footnotetext{
${ }^{10}$ Kitson, Guide, section 6.40 .

1 PN. BRK 3, pp. 790-1; Della Hooke, 'Anglo-Saxon Estates in the Vale of the White Horse', Oxoniensia, 52 (1987), pp. 129-43

${ }^{12}$ Hooke, Anglo-Saxon.
} 
of Warwickshire to the flood plain of the Ock valley, but weg showed no particular correlation with the steep slopes of the Downs.

The foregoing investigation shows that weg's use in settlement names is more specialised than its use for names of tracks and in charter-boundaries, and that in the former context it usually means steep track unsuitable for wheeled vehicles. Names in strēt and pceth carry no implications regarding gradient (except for the North Country dialect peth).

Given that weg, as used in naming track-ways and boundary points in OE charters, has no particular connotations of steepness, whereas weg used in names of DB estates and parishes usually has, it is worth examining the examples where weg is used of these 'major' settlements where no steep gradients are involved.

The most problematic is Stanway in Essex. It is the only weg that (apparently) refers to Roman road(s). It is the only example of weg in the plural and the gradient is a modest 1 in 30. It is first recorded in c. 1000 (eleventh century) in an Anglo-Saxon will (S 1486). The use of the plural could be because the estate had already been split into two, corresponding to the later Magna and Parva Stanways, or because the settlement lies between two close and parallel Roman roads approaching Colchester from the west, or just possibly it could refer to tracks linking the two Roman roads. This position between two Roman roads was more noteworthy than any relief feature in the neighbourhood. As the crossings of the Roman River had spawned the name Copford for the adjoining parish so another ford name was a less distinctive option and Stän-weg seemed a better alternative (see map: fig. 3.10).

The hollow-way now represented by Hollow Court (Holewei, DB) and the Hollowfields Farms, Worcestershire, with a gradient of 1 in 27.2 , was very unlikely to have been the track linking two salt ways running across Lower Lias Clay and alluvium because it was not shown on the O.S. map of 1828-32. It was most probably the salt way running west-east through Hollow Court which had become deeply cut in the clay with frequent usage (see map: fig. 3.10).

Rudway Barton, Devon, is by the river Exe on a river-terrace along which runs a northsouth route heading towards an east-west herepceth a mile and a quarter to the south. It is also on an east-west route from Thorverton crossing the Exe and its floodplain (see map: fig. 3.9).

The only other DB weg with a gradient less than 1 in 20 is Barkway, Hertfordshire ( 1 in 24). It lies on a well-used medieval route from London via Ware to Cambridge. It appears on the Gough Map of c.1360. Barkway and nearby Barley mark a change in topography as this is where, coming from Cambridge, the nearly flat land gives way to the rolling countryside of the northern end of the Chilterns. The name beorc-weg (birch way) serves as a reminder of this change and to use the term weg would emphasise the different nature of this road compared to the two nearby Roman roads.

There are 94 post-DB, non-parish examples of settlements called weg which appear on the 1:25,000 map and whose sites are therefore easily ascertained. In 21 cases the route referred to is uncertain, leaving 73 examples where both site and route are known. Of these 21 have gradients of 1 in 20 or gentler (c. $28.8 \%$ ) The names of these settlements are very reminiscent of the names of tracks and charter boundary marks: there are three Broadways, one Greenway, two Ridgeways, three Holloways, four describing crops/pasture and two describing the surface ( 15 out of 21 ). This would be consistent with newer outlying homesteads having taken their names from an older local track: one which like so many postDB track names and charter boundary features had no connotations of steepness.

The post-DB weg settlements with gradients steeper than 1 in 20 show much more variety among the qualifying elements. As before there are examples of Broad-, Green- and Hollowway but in addition there are two with personal names; a variety of topographical terms such as helde, denu, höh; eight or nine referring to position with respect to the weg; a few referring to stones or rocks - a little more in keeping with the DB corpus and hinting that some of the 
names originated with connotations of steepness very much in mind. As some of the names may have been given some hundreds of years before they appeared in any record this would be unsurprising, but as a group they are not reliable indicators of a steep and well-used routeway.

If weg meant 'steep road', not just 'road', a name like sticol-weg or scēot-weg would be tautologous and unlikely to occur. It is informative to look at the compounds in which words for 'steep, steepness' occur, and in particular if they are found in combination with terms for roads. Thirty-five examples of 'steep' in place-names were found (there may be a few others) made up of scêot ' ('steep slope', eight examples), sticol ('steep', seven), steap' ('steep, precipitous', 10), stigel, stigol ('steep ascent', five and also a 'stile', one), stiepel ('declivity' five, and also 'steeple', one). Eleven qualified a term for a hill (hyll (5), hōh (1), dün (3), ofer (2)). Four qualified $t \bar{u} n$; ten were simplex (Steep HMP, is a particularly nice example of a steep place) and four qualified terms for roads or tracks - one lanu (Winterbourne Stickland) and three paeths (two Sticklepaths in DEV and one in SOM). It was felt useful to call attention to the steepness of some paths, or in the case of Smythapark DEV, to the smoothness or levelness of it, since path could apply to a track of any gradient (though bearing in mind that the North Country dialect form peth meant 'steep track'). There is one instance of a steep stig - Bransty CMB (OE brant 'steep'). Strāet was not combined with a term for steep, partly because few strēets were steep but also because the form of the name, using strät as a qualifier, did not lend itself to that kind of construction. There were no examples of weg combined with a term for 'steep' nor 'smooth'. There are no examples of 'steep wegs' in the charter boundary material either. ${ }^{13}$ If weg in settlement names meant 'steep track' there would be no need to qualify weg with a word for 'steep', and the evidence presented shows that the great majority of settlement names, both major and minor, referred to wegs that were steep. Although this is so, there are a few exceptions as described above. So, although weg might conjure up visions of steepness in the mind of an Anglo-Saxon, it was not so in absolutely every situation; a few were in places difficult to negotiate with a cart for other reasons.

A more difficult question is how and why did the usage of weg for the great majority of settlement names come to differ from its use for minor local tracks, long distance tracks like the Fosse Way and Icknield Way, and in charter boundaries? Although the question of naming was discussed in chapter 1 (pp. 13-20), some further consideration of who named these ways might be helpful. As weg was a widely known term for a common feature it is likely that local people used it to name the local tracks out to their fields, woodland and neighbouring settlements. In early times the Icknield Way was known both as Icenhylte and as Ic(c)enhilde weg in pre-Conquest England, and the Fosse Way was generally known as Foss(e): the form Fosse Way appearing after the Conquest, suggesting that weg was added to pre-existing names to clarify what Fosse and Icknield described ${ }^{14}$ In both these groups weg refers to tracks not settlements. How it came to be used as the name of a settlement which was adjacent to a steep or miry track, and to have a more precise meaning is discussed on pages 20. Although no firm conclusion could be reached, it seemed on balance that those most likely to comment on the steepness of the track were those who were frequent users of it, and those who would be most affected by unusually steep gradients, namely the carters and waggoners. While these might be local people, it would be the habitual, more widely travelled road users who would spread the knowledge that such and such a track was steep and dangerous. A settlement on a routeway stood a good chance of becoming a central place

\footnotetext{
${ }^{13}$ Information supplied by Joy Jenkyns in August 2008 from the Langscape project, not in the public domain at the time.

${ }^{14}$ See for instance PN. GLO I, p. 17 and PN. BDF/HNT, p. 4.
} 
in an estate/locality, and thus these Broad-, Red-, and Stan-ways etc.would eventually evolve into the names of DB estates/ parishes.

In the few instances when weg referred to a track that posed difficulties not from its steepness but from its miriness, the knowledge could still have been spread by regular travellers. The users might deduce from the qualifying elements that some difficulty other than steepness posed the problem - 'hollow' as in Hollow Court WOR, implies a narrow, deep-cut track more likely to form in wet than rocky areas: Flotterton NTB, implies some means of crossing a wet stretch on 'floats'. Occasionally the weg might be more noteworthy than any nearby feature, even though it was not dangerously steep. For instance, at Stanway ESX, a position between two close and parallel Roman roads was more noteworthy than any relief feature (the stän might even refer to the paving although it does not do so in the other examples of Stanway). As the crossings of the Roman River had spawned the name Copford for the adjoining parish, so another ford name was a less distinctive option. The post-DB settlements named in weg with gentle gradients have names suggesting an origin as names for local tracks -'meadow', 'sheep', 'wood', later transferred to small outlying settlements. These subtle differences in nomenclature would be much more obvious to early medieval travellers familiar with the place-naming conventions all their lives, than it is to modern man striving to discern the system from scratch. Just why weg was the term which emerged to describe a dangerously steep road (or, unusually, a miry one) instead of another term altogether, whilst still retaining its original meaning, is unknown. However, the statistics show that weg as used in settlement names did normally mean 'steep or difficult road', and that is the meaning that it is taken to have here, however it may have originated.

In considering the distribution and function of DB and parish wegs in the national road network, it should be noted that, with the possible exception of Stanway ESX, weg is not used of Roman roads. It is sometimes used, particularly outside Devon, of link-roads to, and short-cuts between, long-distance routes; details will be found in vol. 2, pp. 179-81 the appendix to chapter 3. In summary, four wegs are associated with salt-ways: Stanway GLO, Broadway WOR, and Hollow Court WOR with those emanating from Droitwich, and Whaley Hall CHE with one emanating from the Cheshire wiches. Seven wegs are associated with Roman roads and in six of these cases feed into them (the seventh is Stanway ESX). Rather more, eleven, are feeders into ridgeway routes, some of which are well-known as early routes such as the Quantocks and Blackdowns ridgeways, while others such as Ditchedge Lane OXF are presumed to have been in use for millennia but without any real proof. Particularly noteworthy clusters occur around the edges of the Upper Greensand plateaux north and south of Honiton, where the final ascent to the plateau is particularly steep, but once there a long level surface provides a good travel route. Five wegs are associated with other routes: Barkway HRT with an important medieval route to Cambridge, Highway WLT, with a route up onto the chalk downs, and three in Devon where any links to the national network are not at all obvious. Devon's dispersed settlement pattern, its dense network of lanes and the lack of Roman roads have acted against the development of a network akin to that in most of the rest of England. It would need expert local knowledge to determine which might have been the old through-routes in Devon.

In conclusion, weg in major settlement names is a route, rarely a Roman road, which causes difficulties to animal-drawn wheeled vehicles. The most common problem is the steepness of the slope, but occasionally it is the miriness in wet weather. The name weg serves as a warning to carters and waggoners not to use the road.

The many post-DB wegs are not reliable evidence for the presence of pre-Conquest routeways, although some may be useful supporting evidence of a routeway suspected on other evidence. 


\section{b) PATH}

The third road term is path, and its distribution is shown on the map in fig. 3.12

Path is defined as a 'path or track' in EPNE. Gelling says its commonest use is for an upland track, particularly over heathland. ${ }^{15}$ Kitson says that it means 'upland path' in charterboundaries, and a high proportion refer to land over $400 \mathrm{ft}$ or 'if there is not any in the vicinity to the highest that there is' ${ }^{16}$ See fig. 3.6 which details the gradients of peeths which are used as names of settlements and tracks. Watts refers to the north-eastern dialect form peth used of "cleft or sloping hollow forming a break in a cliff or slope, a path leading to the top of a cliff or slope, a hollow or deep cutting in a road', ${ }^{17}$ and this is true of some of the north-country examples: Brancepeth, Morpeth, Pately Bridge, Patton Hall, Painley, and Peth House. In contrast, a few are really low-lying: Panborough, Pathe, and Sticklepath near Barnstaple. As seen in fig. 3.6 the gradients of peeths are very variable, and apart from the sub-group of north-country peths there are no particular gradient characteristics. A summary will be found in fig. 3.14.

Watts also notes that peth sometimes refers to Roman roads. This is true of Gamelspath NTB and Rag Path DUR (no early spellings), neither of which are settlements. Brancepeth and perhaps Patton Hall WML refer to Roman roads. More usually in the case of settlements the peeth, peth is a track leading to a nearby Roman road, as in the case of Gappah DEV, Peth DUR and Bagpath GLO: nearly all the peeths linked to Roman roads are steep tracks.

Nine paeths are connected with old roads: Dupath CNW, Smythapark DEV, Sticklepath (Barnstaple) DEV, Parford DEV, and Sticklepath SOM are feeders to old roads. One, Sticklepath (Sampford Courtenay) DEV, is on an old road, another, Morpeth NTB, is on the Great North Road: for two - Horspath OXF and Alspath WAR - it is difficult to say whether the path refers to a short feeder road or to the old road itself.

Four poeths, including Roppa YON, and Monkspath WAR, are closely connected with routes used by monks in their regular travels, while Yarnspeth NTB, and Pateley Bridge YOW, were drove roads/packhorse routes as well: none of these four is recorded by DB. Seven paths do not appear to link in with any important old routes. Hudspeth NTB, is heading for high moorland. Pathe SOM is the only one of this group not high above sea level.

The path corpus is variable: some have steep, some have gentle gradients; some are on highland or in hilly country, others near to sea level: some are feeders to Roman roads or old roads, while some refer to stretches of these roads: others are tracks which appear to have no direct links to important routes. Some qualifiers refer to wild animals - badgers, eagles, aurochs and perhaps goats - which were likely to be seen from the path, emphasising the remoteness and possible danger on some of them, as do the presence of thieves and murderers (in Dupath and Morpeth); care needs to be taken on the three steep Sticklepaths.

The path corpus is too variable a group to be helpful in identifying major route-ways, but as so many are feeder roads to old routeways they can prompt one to look for evidence that those near larger roads were leading into early medieval through-routes.

\section{c) $\operatorname{STI} G(\mathrm{OE})$, $\operatorname{STI} G R(\mathrm{ON})$}

The fourth road term is OE stīg, ON stigr, which is defined as 'a path, a narrow road' in Smith. ${ }^{18}$ Examples of stigg/stigr are well scattered through England, with instances in Devon, Sussex, Norfolk and the West Midlands; however, the great majority of examples are in Lancashire, West Yorkshire and the Lake District and ON stigr probably makes up a significant proportion of them (see map: fig. 3.13, and list: fig. 3.15).

\footnotetext{
${ }^{15}$ Gelling and Cole, Landscape, p. 89

16 Kitson, Guide, 6.41

${ }^{17}$ Watts, Durham, pp. 16-7

${ }^{18}$ Smith, Elements, 2, p. 152.
} 
There are problems differentiating between stig/stigr on the one hand and OE stigu a (pig)sty on the other. Styal CHE, is thought more likely to refer to a sty. As the first element of Swaintley Hill LNC, is swin, pig, it may be another example of pigsty, but if so a rather remote one, therefore stig, a path, may be a better interpretation.

Although some of these examples refer to tracks over upland or locally high ground by no means all do. Just over a third are steeply sloping at least in part: Bringsty's and Bransty's qualifiers ('brink' and 'steep') imply this, while a further third in hilly areas such as the Weald are moderately steep. Just under a third are in the lowlands, e.g. Cheshire and Norfolk, and have only slight gradients.

The qualifying elements hint at the insignificant size and infrequency of use of the tracks. They suggest that the tracks are prickly with briars; liable to be overgrown with brushwood, birches and 'sprouts' (presumably vigorous young growth); and frequented by wolves, wild cats and hares, creatures normally wary of people. Some are associated with particular people - perhaps someone hunting or farming in the vicinity and to be seen using the track.

It is not always clear which, if any, of today's tracks are referred to in the name, and therefore it is hard to tell if they link into important routes. Four or five (Bringsty, Gresty, Thorfinsty, Hubbersty and perhaps Starling Dodd) do not appear to link into any important routes extant today; four (Chasty, Hawkes End, Braisty and perhaps Swaintley) link into old routes, although not the best-known prehistoric long-distance tracks; thirteen are close to Roman roads and most likely to link into them (Paytefynsty, Bransty, Wolsty, Styford, Hardisty, Spruisty, Strangstry, Styes Lane and the five Sussex examples, the latter a curiously isolated group is in the heart of the Wealden forest clustering round the two Roman roads M 150 and M 14 that give access to them. Harebachesty is part of a Roman road, M 7a. Thorkilsty and Hunters Sty are long tracks over the Tabular Hills of the North York Moors.

These tracks are small, little frequented and often in remote areas. The difficulty of identifying them suggests they were never very important and may not have survived until today. Only one, Corpusty, is recorded as early as DB, most of the others not until the thirteenth century. It is clear that as such they cannot play a significant part in an early medieval national routeway network. At best they may supplement other evidence suggesting an old routeway.

d) $A N S T I G, \bar{A} N S T \bar{I} G$.

The fifth example of an element describing a road is OE anstig,anstig. Since Smith defined anstiga as 'path for one, narrow footpath' there have been several attempts to refine this definition." 19

Kitson believes there were in fact two terms: anstig, 'on' plus 'climbing path', used in south-east and south-west England of steep tracks, and änstigg, 'one path', used in the midlands of link roads, notably the LEI, WAR and HRT examples. ${ }^{20}$

Mary Atkin assembled topographical details of all the anstigs/ anstigs, including their relationship to watersheds and county/hundred boundaries, accessibility, and their status and ownership as revealed by DB. From this she concluded that an anstig/ annstig was a strategic point for the assembly of a small group of men to defend the region, perhaps from a rebel force or from cattle-thieves. ${ }^{21}$

A very much higher proportion of anstigs/ anstigs are in DB than is the case with weg, path or stig, suggesting they were places of some importance. That so many are on watersheds, close to county and hundred boundaries, and are also readily accessible is a

\footnotetext{
${ }^{19}$ Smith, Elements, 1, p. 12.

${ }^{20}$ Kitson, Guide, 6.41.2

${ }^{21}$ M.A. Atkin, 'Places named 'Anstey': A Gazetteer', JEPNS, 30 (1998), pp. 83-98, and summarised in Gelling and Cole, Landscape, pp. 66-7.
} 
reflection of the frequent use of such high ground for boundary lines and ridgeway routes: a not unusual conjunction of functions. The list (fig. 3.16), and the dispersion graph (fig. 3.17) show that half the examples are within three-quarters of a mile of a Roman road or wellknown ancient track, and only two beyond one and three-quarter miles. The inter-quartile range of one and one-quarter miles emphasises this clustering (although it must be noted that the sample is small).

Anstig and änstig are of some use in confirming old routeways because, if their function is as Mary Atkin suggests, they would need to be near routeways for the armed men to reach/intercept the aggressors. They are seldom actually on the routeways for reasons of security and because some traverse high, waterless and therefore inhospitable ground, but wherever an anstig/ anstig occurs there is likely to be a significant routeway nearby.

\section{e) HEREP AETH and HERESTRĀET}

Herepath literally means 'army road' (an army in this context is likely to have been a band of more than 35 men as defined in the late seventh-century laws of the West Saxon King Ine). ${ }^{22}$ Several authors, for instance Hindle and Muir, ${ }^{23}$ assert that a herepceth was a road along which armies were seen to march, and, while armies probably did use these routes from time to time, the term is more realistically interpreted as 'road fit for an army to move along'; in other words 'main road'. Kitson_(unpublished) assessing the occurrence in charter boundaries, says herepceth was primarily a West Saxon term and was superseded by herestrōet. ${ }^{24}$ Certainly the distribution of surviving settlement names bears this out as the majority of herepaths are found in DEV, DOR, SOM, WLT, while the blend here + strōt occurs occasionally in HRT and ESX (perhaps also in WLT but there are only late spellings for these places). In charter boundaries herepceth more often refers to non-Roman than Roman roads, and this is true also in settlement names; because of this it is helpful in identifying important non-Roman roads in southern England. The settlements are listed and mapped in figs 3.18 and 3.19. However, there are not very many of them so it has been expedient sometimes to supplement settlement-name evidence of a routeway with that of the charter boundary herepaeths and heresträts when attention is called to them by authors such as Slater and Cochrane.

The situation is complicated by the fact that herepath is sometimes combined with ford as is here. It is not always clear whether the name is a contraction of herepceth-ford as is probably the case with Halford, Harford (Crediton), Harford (Landkey), Harpford, Hartford (all DEV), Harpenden (HRT), Harpford (SOM), Harpsford (SRY) (since early spellings include at least a ' $p$ ' suggesting the path element), or of here-ford as in the cases of Harford near Ivybridge (DEV), Hartford (HNT), Hereford and Little Hereford (HRE), and Harvington (WOR), see below and fig. 3.18. Herepceth is occasionally combined with other elements as in Salperton (GLO), Harpenden, Harpsfield, Hartsbourne (all HRT), Harptree (SOM).

It is convenient here to mention the five instances of here-ford. David Torvell puts forward a case for these to be fords maintained by the people living at the adjacent settlements called Hereford ( 2 in HRE), Harvington (WOR), Hartford (HNT), and Harford near Ivybridge (DEV) because the ford was a crossing on a useful route. ${ }^{25}$ However, these routes, with the exception of that at Hereford, are not marked out by other place name evidence as being among the most important in early medieval England.

\section{SUMMARY}

\footnotetext{
${ }^{22}$ Lapidge, Encyclopaedia, p. 234

${ }^{23}$ Hindle, Roads and Tracks, p. 34; Richard Muir, The New Reading the Landscape (Exeter, 2000), p. 104.

${ }^{24}$ Kitson, Guide, section 6.39.1

${ }^{25}$ David Torvell, 'The Significance of 'Hereford', JEPNS, 24 (1992), pp. 42-8.
} 
Sträet-tūn and strüet-ford are very important terms identifying the basic framework of the Roman road network in use in Anglo-Saxon times. Other sträet names are also important but must be used with care.

Weg is useful in identifying non-Roman roads, often feeders to the Roman road network, but because of its specialised meaning has its limitations.

Path is not used of major route-ways, but as many are feeders to old routes they may hint at the presence of the latter nearby.

Stigs are too small and remote to have been part of a national network.

Anstigs, although not on important routes, need access to such routes and hint at the presence of one nearby.

The herepaths' and heré strēets' distribution is restricted to southern England, limiting their usefulness, but they are valuable for identifying non-Roman main roads, particularly in the West Country. 


\section{CROSSING-PLACE TERMS}

Inevitably, long-distance routes will have to cross wet ground, streams, rivers, even estuaries at some point; it would be helpful to travellers to know where the crossings of large, wide rivers such as the lower Thames and Severn were in order to choose the most effective routes across or around these barriers, whether by a ford, a bridge or a ferry. In the case of fords it would help to know whether it was a particularly deep or long crossing, or a succession of crossings: what the floor of the ford was like - muddy, sandy, stony: whether it was passable all through the year or whether it was liable to flood in winter or after heavy rain, and whether it was tidal or not.

There are six terms for fords considered here; two ( $r i t u$ and perhaps sarn), British terms; one (vath), an Old Norse term; two Old English terms which became obsolete early on (faer and geweed); one describing difficult conditions (geläd); and the very common ford. Other crossing-place terms are ON ferja, and Latin traiectus; both meaning ferry, and OE brycg; bridge, causeway.

\section{a) FORD}

ford is the most frequently used of any place-name element describing routeways, and yet one of the least useful in establishing the major network. There are about 540 evidenced up to and including $\mathrm{DB}$, and a further 750 or so from DB to 1500 known so far.

The fords themselves vary in size from major river crossings such as the Thames at Oxford and the Ouse at Bedford to streams small enough to leap across, like those at Yelford and Hatford BRK. The name can imply the presence of a causeway (a word introduced from French after the Conquest and therefore not in the Anglo-Saxons' vocabulary), where a raised track across wet ground led to the crossing. Such a causeway would be very important where the floodplain was wide and frequently waterlogged. Examples exist at Stanford in the Vale OXF, and Whittlesford CAM, the latter now a tarmaced footpath across the fields to the Cam. At Orford SFK, the 'ford' probably refers to the raised village street leading from below the church across low-lying ground to the harbour.

The distribution of fords evidenced by 1086 is shown on the map (fig. 4.1). It is uneven for many reasons. The paucity in the Weald is largely due to the thin spread of DB estates there whereas Devon, which has large numbers of small estates, has opportunity for a much greater density of early ford names - about 77 (in the Weald ford names are mostly post-DB minor names. Devon has over 350 examples in all, nearly a fifth of the total for England). Areas of chalk and limestone upland such as the Chilterns, Salisbury Plain and the Yorkshire Wolds, having little surface drainage, naturally have fewer river crossings than do clayey areas with a denser drainage network. Some rivers have very few fords along them - they may be those difficult to cross, deep and muddy-floored for instance; others, shallow and firmly floored, have numerous fords. Upstream of Cambridge the Cam is shallow and gravel-floored, easy to cross at places such as Great Chesterford, Whittlesford, Dernford and Shalford. Likewise other chalk-country streams, such as the Salisbury Avon, the Wylye and the Nadder, have many fords along their length. The lower reaches of the larger rivers such as the Thames, Trent and Severn are much too deep and wide for fording; a ferry or bridge is needed in these circumstances. The names East and West Bridgford NTT, called Bridgford by 1086, suggest an early replacement of the ford over the Trent with a bridge; in fact such a bridge is mentioned in ASC s.a. 924. Glanford Brigg LIN, is recorded as Glanford' in 1183, but 
Pontem de Glaunford by 1203 . The courses of many rivers, especially where they flow through built-up areas, have been modified, usually by narrowing, containing and deepening, thus destroying a number of possible fording places, that at Westminster being an example; changes in sea-level and the silting of estuaries will also have had their effect. The northern counties of Cumberland, Westmorland and Yorkshire have fewer ford names than might be expected, but here ON vath, 'ford' is common and may sometimes have replaced ford names

The qualifying element often describes the nature of the ford. It can be helpful to know if the ford is shallow (13 examples) or deep (13, mostly in Devon). It may be hidden and difficult to find (11): the Darnford in SHR is in the folds of the Long Mynd at the head of a hop (remote valley), while Dornford OXF, is on the Dorn hidden on the eastern approach until the road suddenly rounds a bend and plunges steeply down to the river-crossing. The Somerfords (GLO, WLT, CHE) are passable only during the low flows of summer, while the four Effords in the rias of south Devon are only passable at low tide (a ria is a drowned, nonglaciated river valley in an upland area). The nature of the bed is of considerable interest to the traveller; there appear to be only two examples of muddy fords ( $\mathrm{OE}^{*}$ mudde) perhaps because ful ('foul', 13), scearn ('muck', 3) and scitere ('sewer', 2) are more frequently used alternatives, but there are many Sandfords (c.28), three gravelly fords (Greatford LIN, Girtford BDF, and Chillesford SFK), and three chalk fords, one on the Icknield Way (foot of the Chilterns) and two on the Cotswold Limestone. Stān-ford is particularly common - over 50 examples manifest as Stanford, Stamford, Stainforth and Sto(w)ford; stone gives a firm bottom, but is not very easy to cross if the stones are large, tumbled and slippery. Popel, the first element of (Newton) Poppleford, is a rare element but here refers to the Budleigh Salterton Pebble Beds, which produces a mass of angular pebbles on the floor of the river Sid. Bradford (broad) occurs over 25 times, but no examples of narrow have been noted.

Longford / Langford was the subject of a note in Britannia in 1992 where Jermy suggested that the name was indicative of the presence of a Roman road. ${ }^{1} \mathrm{He}$ assembled 52 examples including those in Wales, but without listing them or giving any dates when they were first evidenced. He noted that:

$31 \%$ of examples were within $1 \mathrm{~km}$ of a Roman road or $40 \%$ omitting DEV, CNW and SOM

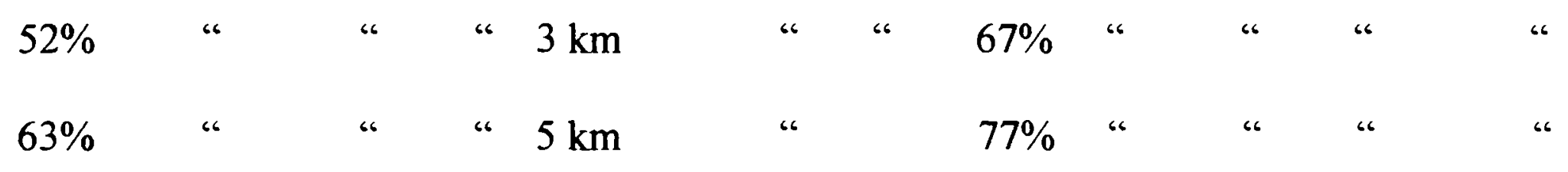

As he admits, it does seem unlikely that a place would be named after a crossing that was as much as $5 \mathrm{~km}$ ( 3 miles) away. This would be especially true if there was another streamcrossing nearer to the Longford than the Roman road crossing, which is the case in some instances. In other places, although the lang-ford is close to the Roman road, the Roman road does not cross any stream at that point, e.g. at Langford DEV near Honiton it is a feeder to the Roman road that crosses a stream, not the Roman road itself. At Steeple and Hanging Langford WLT the Harroway crosses the Wylye; there is a Roman road only $1 \frac{1}{2}$ miles away but it does not cross any river nearby. This pattern is repeated elsewhere. Jermy says he has not checked the topography in every case and so one cannot be sure that all his lang-fords really did refer to Roman roads crossing streams. For a summary of this information see fig. 4.2 .

\footnotetext{
' Kenneth E. Jermy, 'Longford and Langford as Significant Names in Establishing Lines of Roman Roads', Britannia, 23 (1992), p. 228
} 
I have noted 51 examples of Longford/Langford in England, of which 36 are examples of lang-ford evidenced by 1500 (fig. 4.2). In addition there is a Longworth HRE (Langeford, 1160-70), but Langford NTT incorporates a personal name and has been excluded. Thirtyone are settlement names, four are bridges and one a road name. Of these:

$19.4 \%$ (7) are within $1 \mathrm{~km}$ of a Roman road

$\begin{array}{lllll}38.9 \% & (14) & \text { “ } & 3 \mathrm{~km} & \text { “ } \\ 50 \% & (18) & \text { “ } & 5 \mathrm{~km} & \text { “ }\end{array}$

These percentages are lower than Jermy's, for reasons suggested below. None of these calculations take account of whether or not a Roman road actually crosses a stream in the locality (see above). If the Roman road does not cross a stream or use a causeway in the vicinity of the Longford/Langford then the name is not indicative of a Roman road; the two are adjacent by chance.

It is worth applying the chi-squared test to these figures to see if there is a significant correlation between the Langfords/Longfords and Roman roads. The odds of:

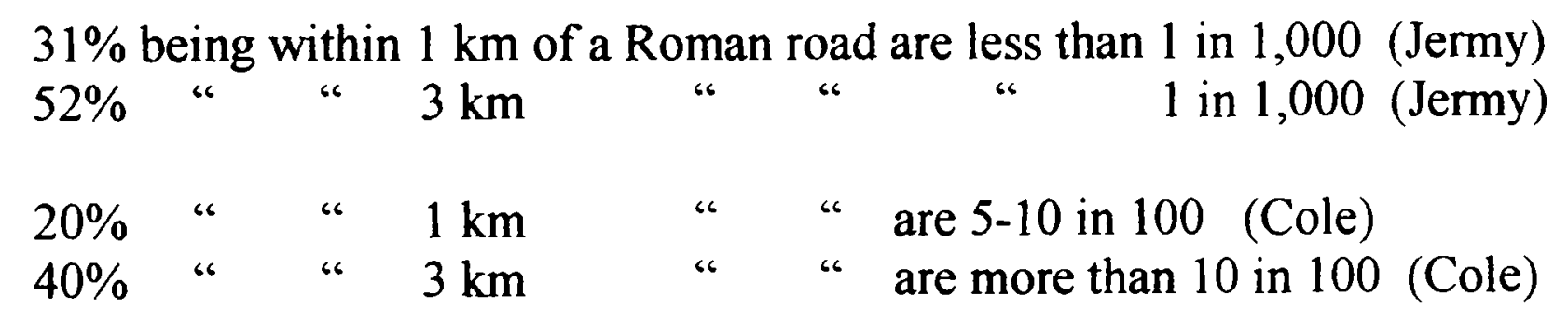

Figures for $5 \mathrm{~km}$ are unreliable.

It would appear that Jermy has identified a significant correlation between Roman roads and Langfords and Longfords using the examples he had assembled, but that the examples I have assembled show a much poorer correlation. Without having a full list of all Jermy's examples it is hard to say why there is such a difference in the results. It could be that any post-1500 coinages, if indeed any were included, are more likely to relate to Roman roads than earlier ones - an unlikely situation. It could be that Jermy was using a much denser network of Roman roads than that shown on the O.S. map of Roman Britain; in one instance he seems to have used Stratton in Cornwall to indicate the presence of a Roman road when the said Stratton does not derive from strēet at all but from Old Cornish *strad 'valley'; it is unclear whether the afore mentioned Langford NTT, has been excluded or not. In neither case were the examples where a lang-ford was near a Roman road, but did not refer to the latter's crossing of a stream, excluded. Hence all the results show a better correlation than actually exists. The presence of eight examples (nearly a quarter of the pre-1500 examples) in Devon west of Exeter, where Roman roads are so few, suggests at the outset that the correlation will not be good. Indeed Jermy's figures when he excludes Devon, Somerset and Cornwall are much improved. This is another instance like Coldharbour (see chapter 5)

illustrating the importance of taking an England-wide survey to eliminate local anomalies in distribution. Using the information in fig. 4.2 it can be seen that in only three cases does a lang-ford refer to a Roman road crossing of a stream or river (DBY, GLO, HRE). In two other cases (OXF, SHR) it is possible but not certain. In the other cases where a lang-ford is within 3 miles $(5 \mathrm{~km})$ of a Roman road the name lang-ford does not relate to the road but to some other stream crossing, even if the Roman road crosses the same stream elsewhere (CHE, DEV, DOR, MDX, WLT). In six cases a lang-ford refers to a crossing by an old route, including three herepeths and the Icknield Way. 
The situations in which the name lang-ford was used were varied: a few were crossings of small rivers, some were crossings of one small stream, a similar number where two, even three, small streams were crossed in quick succession. Some crossed apparently flat, wet valley floors, others were in clayey country and therefore ill-drained (on Oxford Clay or Keuper Marl for instance). Unfortunately, it is not possible to tell from maps precisely how the term ford was being used: whether the roads approaching the fords ran on causeways or not. Some crossing the wider alluvium-filled valleys probably did; others in steep narrow little valleys would not have space for a causeway, at least not of any length - it is unclear why these fords should be described as 'long'. The lang-fords need investigating in the field before a better understanding of the situations in which 'lang-ford' was deemed a suitable name for a place can be achieved.

The term lang-ford as an indicator of Roman roads is not proven, nor is it related to Roman roads and old routes in sufficient numbers to be used as an indicator of a road-in-use. The one category of ford names that is a reliable indicator is strēt-ford already considered under strētt, while the occasional weg-ford, pæeth-ford and stig-ford have also been considered in Chapter 3.

There are nine Saltfords and Saltersfords which have been used along with other salt names to identify salt routes. ${ }^{2}$

The only other category of ford names occurring at all frequently along Roman roads and ancient tracks is that incorporating a river name; even so, only about half are related to important routes, so these cannot be used to identify the roadway network.

Given the large number of ford names, it is surprising that more of the places where Roman roads cross rivers do not bear them. Sometimes this is because there was a Roman station at the crossing and -ceaster was used in preference. Only the road from London to Caister St Edmunds near Norwich (M 3) has a regular series of ford names along it, while the much shorter Charmouth to Exeter road (M 49) also has a good series. Most other Roman roads only have occasional ford names along their lines.

Ford is used in such widely differing situations in place-name coinage - on streams large and small, and on tracks of all sizes and degrees of importance - that it is of no use as an indicator of major route-ways unless it happens to be one of the twenty or so strēt-fords. At best it can confirm the nature of the crossing of a known important road over a stream or river.

\section{b) $V A T H$}

These are listed in fig. 4.3 and mapped on fig. 4.4

Vath is the Old Norse term for a ford. Its distribution is somewhat restricted as it does not appear in East Anglia and only rarely in the East Midlands. The swathe of country in which it is most common lies from the Lake District, across the Pennines to the Vale of York and the North York Moors, but only in Cumberland and Westmorland does it occur in greater numbers than ford. It is not often used as a settlement name; there are eight examples in DB, six or seven more are parishes or townships, and there are 31 other (present-day) settlements (cf. 530 major names in ford), most of which are tiny; additionally, there are some lost vaths which might have been settlements, and some surviving as names of bridges and becks. They mostly refer to crossings of small mountain streams in remote places. However, five appear to refer to fords on Roman roads (none are in $\mathrm{DB}$, one is a parish/township name); of these, three are settlements (Langwith LIN, Winderwath WML, Skelwith WML); one, Smallways YON, survives as the name of a bridge; and the name of another, Waspatrickwath, has been

\footnotetext{
${ }^{2}$ W.B. Crump, 'Saltways from the Cheshire Wiches', Transactions of the Lancashire and Cheshire Antiquarian Society, 54 (1940), pp. 84 -142; F.T.S. Houghton, 'Salt-ways', Transactions of the Birmingham Archaeological Society, 54 (1932), pp. 1-17.
} 
lost, but the crossing survives as Crofton Bridge. A further three are on feeder roads very shortly before they join a Roman(ised) road: (Stenwith LIN, Brawith YON, and Thoroldwath (lost, perhaps now Wath) CMB), and so link into the route-way network.

Vath therefore, like ford used so often of insignificant places on insignificant tracks, is not of any value in identifying the major routes in northern England. At best it occasionally confirms the place where a stream is crossed by a Roman road.

\section{c) $G E L \bar{A} D$}

These are listed and mapped in figs 4.4 and 4.5. Details are in vol. 2, pp. 186-8

OE gelād is a term meaning 'difficult crossing' or, more precisely, 'crossing liable to be impassable due to flooding'. This has been verified by fieldwork during periods of flooding: the minor road along the east bank of the Severn through Wainlode and Abloads Court GLO, was under water for long stretches because the flooding Severn ponded back the tributaries which then overflowed onto the adjacent fields and roads. Likewise the Thames crossings at Lechlade GLO, and Cricklade WLT, are inundated by flood-water at times and quite impassable on foot, while nearby Fairford GLO, (the 'fair' or 'good' ford) can still be easily passable on the same occasion. Equally, the Ouzel at Linslade BUC, and the Evenlode GLO, flood their valleys so that the crossings are impassable. At Framilode GLO, the floods occur when both unusual tidal and weather conditions coincide (vol. 2, p. 187). Prior to these observations in the 1990s there had been some debate as to the meanings of gelād and lād; the two can be impossible to separate if the spellings are post-Conquest. Ekwall came close to the truth when he suggested that läd meant 'water-course' and gelād 'passage over a river' ${ }^{3}$ The debate was further discussed and refined by Gelling, and by Gelling and Cole; ${ }^{4}$ the suggestion that gelād means 'difficult crossing' and läd means 'artificial water-course' has been followed here. Hooke has misinterpreted Gelling's similar comments in the Landscape of Beowulf which says '... the crossing ... is likely to have been not over the main river, but over streams crossed by roads running alongside it', 5 when she says that '... at least on the Severn these places [geläds] could never have been forded' ${ }^{6}$ Gelling never claimed that geläd referred to a ford over the Severn.

There are six safe and four probable examples of geläd. All ten are liable to flooding, eight by rivers and two by tidal water in estuaries. In fact tidal flow can aggravate the flooding in two or three of the riverside geläds too. Three gelāds, Cricklade WLT, Aqualate STF and Portslade SSX, are on stretches of Roman road; one, Lechlade GLO, is at the end of a saltway; and one charter-boundary example is on a well-established old route. The track through Wainlode, Abloads and Framilode parallels the Roman road from Droitwich through Worcester and Gloucester, and could have made a pleasant alternative route for salt traders if road conditions allowed. Any travellers would be warned by the presence of a geläd on their route that it was liable to be impassable in times of flood and that they should seek an alternative. The term is not suitable for identifying major routes since some examples are on quite minor ways, but it is useful as confirmatory evidence that a route was in use in early medieval times, particularly as some of them are recorded well before the Norman Conquest.

\section{d) GEWAED}

There are probably fourteen examples of gewced known in settlement names; they are mostly eastern and southern in distribution (see map: fig. 4.7, list: fig. 4.5, and details in vol. 2 , pp. 188-91). It is thought to be a term that became obsolete for coining names early on and

\footnotetext{
${ }^{3}$ DEPN, s.n. lād, gelād.

${ }^{4}$ Gelling, Place-Names, pp. 73-6;Gelling and Cole, Landscape, pp. 81-3

${ }^{5}$ Margaret Gelling, 'The Landscape of Beowulf', Anglo-Saxon England, 31 (2002), pp. 10-1

${ }^{6}$ Della Hooke, 'Uses of Waterways in Anglo-Saxon England' in Blair, Waterways, p. 38.
} 
was superseded by ford. ${ }^{7}$ Gewaed is translated by Ekwall and Smith as 'ford' and is cognate with vath, while Gelling suggests it may, in addition, have carried the implication of a causeway to reach the watercourse which was to be crossed by wading or other means. ${ }^{8}$ An examination of the sites of the gewaeds makes it clear that a causeway would be a great asset at many of these crossings. Seven, or perhaps eight, of them are over tidal water, and would necessitate traversing mud flats and salt marsh in order to cross the watercourse at low tide (if it was suitable for wading), in these conditions a causeway over the mudflats would be very useful. If the mud was very tenacious it might be better to wait for high tide and take a ferry. In three cases the crossing gives access to an island; that at St. Nicholas at Wade KNT, to the Isle of Thanet; that at Iwade KNT, to the Isle of Sheppey and that at Wade Court (Havant, HMP) to Hayling Island. Other tidal gewoeds are at Cattawade SFK, the lowest crossing point of the Stour estuary; Wadebridge CNW, the lowest crossing point of the Camel estuary and Wade (SFK) over the Waveney arm of the Great Estuary. The crossing of the Blackwater at Wade Court (Netley Marsh, HMP) though tidal, was much shorter and less muddy than the other six tidal crossings. The crossing of the Waithe Beck LIN, might have been affected by high spring tides. Four of the remaining crossings were over substantial rivers, the Nene, Wensum, Ivel and Salisbury Avon, which have braided channels in wide, wet flood-plains liable to inundations. These eleven gewceds clearly would present difficulties to travellers, and certainly the tidal ones could be dangerous if one were not aware of local conditions. The term would serve as a warning to anyone using the route.

Wathe, now St. Lawrence, is built on the land-slipped ground of the Undercliff on the southeast coast of the Isle of Wight. The route may have been regarded as hazardous because of the danger of cliff-falls and the hummocky oft-changing nature of the route.

Landwade CAM, is atypical and as there are there are also problems in interpreting the spellings, Landwade must remain an uncertain example (see vol. 2, p. 188-9).

The gewceds do not occur on major Roman roads, although Biggleswade, Ayleswade and perhaps Cattawade are on minor Roman roads and Lenwade is on a known old route into Norwich, so they are not helpful in identifying the main route-way network. However, they are valuable as indicators of routes used to reach islands, and of short cuts across estuaries to avoid detours inland to narrower, easier crossing places.

\section{e) $F \not E R$}

These are listed and mapped in figs 4.6 and 4.7, with details in vol. 2, pp. 191-2.

Far is an OE term meaning 'a passage' (Ekwall), 'a road, a passage, a ford, a ferry' (Smith), 'a passage, probably a difficult passage' (Gelling and Cole). This is a rare element considered to have become obsolete at an early date, and to have only three safe and one possible example. ${ }^{9}$ All three safe examples are closely associated with Roman roads where they cross wet ground and streams or rivers. Walter Hall and High, Magdalen and Little Laver in Essex are alike in that they refer to Roman road crossings of small streams flowing over clayey ground. The crossing at Denver NFK was of a much larger river, the Great Ouse, which had been bridged by the Romans, although the bridge might not have survived into the early medieval period. Farforth LIN, is a less safe example, ${ }^{10}$ and it is curious that it should have been combined with ford which would have produced a tautologous compound, unless this happened after the term faer was no longer understood. It lies in the chalk of the Lincolnshire Wolds where ford names, e.g. Belchford and Tetford, have arisen on equally tiny streams, which are features worthy of note in a largely waterless district. A minor

\footnotetext{
${ }^{7}$ Gelling and Cole, Landscape, pp. 94 -5.

${ }^{8}$ DEPN, s.n. (ge)waed; Smith, Elements, 2, p. 234; Gelling and Cole, Landscape, p. 95

${ }^{9}$ DEPN s.n faer; Smith, Elements, 1, p. 163; Gelling and Cole, Landscape, pp. 70-1.

${ }^{10}$ Gelling and Cole, Landscape, p. 78
} 
Roman road has been identified by Owen ${ }^{11}$ descending quite steeply down to a raised path through wet ground, before crossing Farforth's little stream, and in the latter respect it resembles the Lavers and Walter Hall. Cameron's interpretation 'the ford giving passage' could therefore be applicable. ${ }^{12}$ Hollinfare LNC and Farway DEV are no longer considered to contain far. All are useful in identifying routes in use, although the sample is much too small for any statistical test to be applied.

\section{f) RITU}

See figs 4.6 and 4.7, and details in vol. 2, p. 192

ritu is a British term, ancestor of Welsh rhyd, meaning 'ford'. It is uncommon in placenames surviving from the medieval period. It was in use in Roman Britain, occurring in the names Anderitum (Pevensey SSX), Camborico/ Camborito (possibly Lackford SFK) and Durolito (perhaps Chigwell ESX), although none of these names survives today. There are four or five examples known from medieval spellings, which might be the earliest surviving records of names that were in use in the Romano-British period. Two are on important routeways: Penrith CMB, on a Roman road where it crosses the river Eamont, and Leatherhead SRY, on the Mole on a route from London to Winchester or Portsmouth. Tretire HRE, and Ridware STF, are on minor routes, while Redmain CMB is probably not an example of ritu. It cannot therefore be used to identify major routes in the early medieval network, but helps to confirm those suspected to be in use from other evidence.

\section{g) $S A R N$}

See figs 4.6 and 4.7, and vol. 2, pp. 192-3 for details.

Sarre, on the Isle of Thanet KNT, might be an example of British sarn, 'a causeway, a paved road', and if so, would be the only one recorded in DB. It refers to one of two crossings of the Wantsum Channel, passable only with care at low tide. This and the St. Nicholas at Wade crossing ( $q . v$. under gewced) were locally important routes. The term is an interesting 'one off', but being the only example cannot be used elsewhere in identifying the early medieval route-way network.

\section{h) FERJA}

See figs 4.6 and 4.7, and vol.2, p. 193 for details.

ferja is the ON term for a ferry. There was a ME term ferrye, but no OE equivalent used in place-names. There are just three settlement names, referring to two ferries, recorded by 1086 : North and South Ferriby and Ferie, later Ferrybridge YOW. These were important links in the route-way network. The ferry across the Humber between South and North Ferriby linked Lincolnshire to Yorkshire, or more particularly Hornchurch (or even Skegness) via Caistor on M 270 to a landing near Brough, whence the road to York (M 2e) ran. A traveller from Lincoln going due north on Ermine Street (M 2d) would reach the Humber two and a half miles west of the Ferriby crossing so would need to make a small diversion to use it (DB records a ferry at Winteringham, at the end of Ermine Street, which would have been more convenient. DB also records ferries at Grimsby and Barton across the Humber; and at Lea LIN, Southwell and Fiskerton NTT, and Weston DBY, all across the Trent. There were more ferry services than the place-names reveal). ${ }^{13}$

\footnotetext{
${ }^{11}$ A.E.B. Owen, 'Roads and Romans in South-East Lindsey: the Place-Name Evidence', in A.R. Rumble and A.D. Mills (ed.), Names, Places and People (Stamford, 1997), p. 26

${ }^{12}$ Kenneth Cameron, A Dictionary of Lincolnshire Place-Names (EPNS, Nottingham, 1998), p. 43.

${ }^{13}$ DB Lincolnshire, folios 354b, 354c, 343b, 354c, 347a; DB Nottinghamshire, folios 283a, 288d; DB Derbyshire, 273a.
} 
The ferry at Ferrybridge took travellers on the Great North Road across the river Aire, whereas the Roman road (M 28b), two to three miles west at this point, crossed the Aire at Castleford.

In the twelfth century there are references to two ferries in place-names; that at Wawne YOE, referring to a crossing of the river Hull, would have been instigated by the Abbey of Meaux which was carrying out extensive drainage works in the marshy Hull valley. Kinnards Ferry LIN, the name of the ferry between Owston Ferry and East Ferry villages, plied across the Trent. By the fourteenth century there are increasing numbers of references to ferries and ferryboats, especially across the Trent and Mersey, but few give rise to settlement names; they are likely to be post-Conquest institutions appearing as the communications network improved.

\section{i) TRAIECTUS}

See figs 4.6 and 4.7, and vol. 2, pp. 193-4 for details.

If the DB name of Skegness, Tric, is a shortened form of Latin traiectus, a ferry, as suggested by Owen and Coates, ${ }^{14}$ it must have referred to the Roman ferry between Skegness on the Lincolnshire side of the Wash to Holme-next-the-Sea (or possibly Hunstanton) on the Norfolk side. The name Tric would appear to be early since it is a borrowing from the Latin through Brittonic, and probably given when the ferry was still functioning. There are two possible scenarios for the change of name from Tric to Skegness by 1166 (Skegness comes from O Dan Skeggi (a personal name) and ON nes, 'headland'). If the change was that of the name of a settlement, it could imply that the ferry was no longer operative. Had it still been functioning a name incorporating ferja might have been expected for such a notable crossing rather than a name describing a headland. There is no mention of a ferry in Domesday book, so perhaps by this time coastal changes had made the crossing too dangerous. In any case, why was it thought necessary to change the name? Names did get changed, but also names whose meanings were no longer transparent stayed in use. The second scenario seems to offer a better explanation for the change. The DB name Tric refers to an estate of three and a half carucates. Within this estate may have been an unrecorded settlement called Skegness, as well as a settlement called Tric. When the site of Tric was destroyed by the sea it left Skegness as the main settlement, and the one recorded in subsequent documents. In other words, there was no change in any settlement name; Tric was destroyed; Skegness survived, but there was a change in the name of the estate. Like Sarre, it is an interesting 'one off', clearly of local importance, but not found elsewhere in the route-way network.

\section{j) $B R Y C G$}

See figs 4.8 , and 4.9 .

The modern meaning of 'bridge' as a structure spanning a waterway, allowing the passage of traffic over it and water to flow under it, is more specialised than the OE sense of brycg. Because the OFr term causee (and the later causeway) was a post-Conquest introduction, both brycg and ford often encompassed a raised track as well as 'bridge' and 'ford' in the modern sense. The crossing to Northey Island described in The Battle of Maldon is referred to as a brycg in one place and ford in another. ${ }^{15}$ Swarkeston Bridge over the Trent near Stanton by Bridge, referred to as Ponte de Cordy in 1204, was about a mile long, most of it a causeway with numerous arches (Ogilby records 30 ) across the flood plain and with a bridge proper over the Trent. Grandpont in Oxford incorporated a similar arched causeway and was built in the late $11 \mathrm{c}$. Thus although brycg could mean the same as modern 'bridge' it could also mean a causeway or causeway and bridge combined.

\footnotetext{
${ }^{14}$ Arthur Owen and Richard Coates, 'Traiectus/Tric/Skegness: A Domesday Name Explained', Lincolnshire History and Archaeology, 38 (2003), pp. 42-4

${ }^{15}$ Harrison, Bridges, pp. 26, 104.
} 
For a country to function effectively a good infrastructure of routeways is needed; important centres for trade and administration need to be linked by roads and crossings. A bridge was much preferable to a ford because it could be used whatever the state of the river and because the travellers and the baggage would not get wet or swept away. Harrison believes that bridgebuilding became an important activity, one in which a great deal of money and labour were expended, after about $700 \mathrm{AD} .^{16}$ It was in the mid-eighth century that bridge-work along with work on fortifications and serving in the fyrd became a widespread duty recorded in the charters of the time, the first mention being in 749. The first mention of bridge-work is when Aethelbald of Mercia, at a council held at Gumley in 749, laid down the privileges and duties of the church; the latter included work on bridges and fortresses. ${ }^{17}$

The presence of a bridge over a sizeable river would attract routes to that crossing as people chose to divert a few miles to use a safe, dry passage rather than a ford. A bridge at Abingdon built in the early fifteenth century attracted westward traffic from the crossing at Wallingford to Abingdon. ${ }^{18}$ The investment of time, labour and money in building a bridge ensured that efforts were made to keep it in good repair - piers protected from scour and the timber superstructure renewed as necessary. The Roman bridge at Rochester, consisting of stone piers and a timber carriage-way, was kept in repair by nearby estates, each of which was responsible for a particular section; ${ }^{19}$ it finally collapsed in a flood in 1381 . One of the effects of bridge building was to fossilise the route-way system at least on routes where major crossings were concerned and to concentrate traffic at these points. This applied not only to the Anglo-Saxon bridges but also where there were surviving Roman bridges. Further, post-Conquest, bridgebuilding would have modified the route-way network further and widened the choice of routes between distant destinations. To trace the Anglo-Saxon routeway network it is important to know which bridges existed in Anglo-Saxon times, and because this study is based on placename evidence only those recorded in names by DB are used here.

The Romans built many bridges in England; Cook plots 77 (un-named) on a map of England. ${ }^{20}$ A bridge over a large river or a deep ravine would be both useful and eye-catching to an Anglo-Saxon, and it might be expected that a nearby settlement would be named from it. In practice it seems this rarely happened. The superstructure might have been ruinous by the time the Anglo-Saxons reached the locality; an earlier name may have commemorated the bridge, but the name was changed when the bridge became ruinous. In many cases Roman bridges over substantial rivers were in Roman settlements, whose ruins were a more dominant feature in the landscape than the bridge, and so the Anglo-Saxons named it -ceaster rather than -brycg: there are many examples of this, such as Binchester, Chester, Cirencester and Rochester. A few places which once had Roman bridges had Anglo-Saxon names meaning, loosely, a ford, implying that the bridge was no longer usable, notably Denver NFK (see under foer), Cricklade WLT (see under geläd), and Billesford NFK, all recorded by 1086 . Chollerford NTB, recorded in 1185, may have become the crossing of the North Tyne when the bridge at Chesters was no longer usable. This leaves a tiny core of brycg settlement-names which may refer to Roman bridges, although it does not necessarily mean they were usable.

At Piercebridge DUR, the stone foundations of the Roman bridge can still be seen. This bridge over the river Tees carried traffic on the main route (M 8) from York to Hadrian's Wall. The meander here was shifting northwards leaving low-lying wet ground on the south side, necessitating the building of a causeway to the bridge perhaps using the osiers mentioned in the

\footnotetext{
${ }^{16}$ Harrison, Bridges, pp. 32-8, 221.

${ }^{17}$ Harrison, Bridges, p. 35; Stenton, Anglo-Saxon, p. 205.

18 Harrison, Bridges, p. 44.

${ }^{19}$ N. Brooks, Communities and Warfare, 700 - 1400 (London, 2000), pp. 219-65.

${ }^{20}$ Martin Cook, Medieval Bridges (Princes Risborough, 1998), p. 9.
} 
name (OE persc) ${ }^{21}$ These osiers prompted Watts ${ }^{22}$ to comment 'the reference can hardly be to a crossing of the Tees; more likely it referred to a causeway of faggots laid across marshy ground' - this may be so, but why would one build a causeway here if not to facilitate the crossing of the Tees either by bridge or ferry? A continuing shift northwards of the river would eventually undermine the northern foundations causing problems of stability and access The survival of the bridge into Anglo-Saxon times seems very likely no matter what part the osiers played.

Corbridge NTB, is recorded c. 1050 and means 'the bridge (over the river Tyne) by (the Roman settlement of) Corstopitum'. It was an important stone-piered bridge on the same main supply route (M 8) to Hadrian's Wall as Piercebridge. ${ }^{23}$ It must have been a substantial structure to have crossed as large a river as the Tyne; this probably enabled it to survive in use into the Anglo-Saxon period.

Horsebridge HMP, appears in the records in 1236; it has nothing to do with horses, but is probably from $\mathrm{OE}$ hos, a shoot or tendril. Horsebridge is where M 45a, the Roman road from Winchester to Old Sarum, crosses the Test. A line of piles has been seen in the river at this point, but not dated. It is not possible to say whether the bridge here was Roman or medieval. ${ }^{24}$

Boroughbridge YOW, at first glance seems to refer to the crossing of M 8 over the river Ure. However, it is not where the Roman road crossed the river from Aldborough (Isurium), but where the Great North Road from Castleford crossed the Ure shortly before joining M 8 on its northward way. The bridge was built in the early twelfth century and named from Aldborough, 'the old borough' as 'the bridge by the borough'. ${ }^{25}$ It drew travellers from the Roman road to the Great North Road.

At Low Borrow Bridge WML, the remains of a timber bridge over the Borrow Beck ('stream of the (Roman) fort') have been found but not dated; the name Borrow Bridge does not appear in the records until 1679 . The nearby crossing of $M 7$ over the river Lune is recorded as Salterwath Bridge in 1811 . Both names appear so late in the records that they are not reliable indicators of a Roman bridge in use in early medieval times. ${ }^{26}$

There are thus but two, possibly three, settlement names that refer to Roman bridges: Piercebridge, Corbridge and perhaps Horsebridge. This is a small number considering the numerous bridges built by the Romans. Floods and neglect would have destroyed many of their smaller timber bridges. Others over tiny streams would have been little more than culverts: to have lost these bridges would not have been a serious problem to the Anglo-Saxons; the watercourses were small enough to ford or to span with a simple wooden bridge. It is only the stone-piered bridges with massive timber carriage-ways over the larger rivers that would have stood much chance of remaining usable and playing an important part in the route-way network. Probably only a few surviving bridges were commemorated with a bridge placename, others subsumed in ceaster names or the like.

There are nine other brycg names in $\mathrm{DB}$, and two in ASC, probably associated with Roman roads but not so far as is known with Roman bridges: At Cambridge there was a Roman fort, Duroliponte, on the north bank of the Cam, and it is likely that the Romans had bridged the river. ${ }^{2 f}$ However, Roman Cambridge seems to have been deserted from the fifth to the eighth or ninth century, and its bridge would have collapsed. The early name of the settlement used by

\footnotetext{
${ }^{21}$ A.P. Fitzpatrick and Peter.R. Scott, 'The Roman Bridge at Piercebridge, North Yorkshire - County Durham', Britannia, 30 (1999), pp. $111-32$

${ }^{22}$ CDEPN, s.n. Piercebridge.

${ }^{23}$ Dymond, Roman Bridges, pp. 136-64

${ }^{24}$ Dymond, Roman Bridges, p. 193 (s.n. Bossington)

${ }^{25}$ Hindle, Medieval Roads, p. 12.

${ }^{26}$ D. P.Dymond, Roman Bridges, p. 163.

${ }^{27}$ D.P. Dymond, Roman Bridges, pp. 136-64
} 
Bede (c. 731) was Grantaccestir. The earliest surviving reference to -brycg as a replacement for -cester in the name is in ASC s.a. 875. The form (jrontabricc, found in Felix's Life of St Guthlac about 745, is in fact an eleventh century alteration of the original form (jronte ${ }^{28}$ and does not imply that there was a bridge over the Cam in the mid-eighth century. ${ }^{29}$ Both Haslam and Lobel suggest that the Cam was bridged by Offa when wanting to link Mercia to the east coast. $^{30}$ If so, the bridge would have been built before Offa's death in 796 , but after c.745, and thus available for use by the later Anglo-Saxons. Eastbridge SFK, is on what may be a minor Roman road running north-south parallel to the Suffolk coast, crossing the ill-drained land beside the Minsmere River, probably necessitating a causeway; ${ }^{31}$ Bridge KNT, is on M la the road from Canterbury to Dover at the crossing of the Nailbourne, a seasonal chalk stream; Hubbridge ESX, is where M $3 b$ the London to Colchester road crosses the little river Brain; Brigstock NTP, is where M 57a the Godmanchester to Leicester road may have crossed the Harpers Brook and Stamford Bridge YOW, is where M 80 crossed the Derwent. Bridgnorth SHR, mentioned in ASC s.a. 896 but not in DB, is where a lesser-known Roman road from Greensforge to Corve Dale and Craven Arms crossed the Severn. ${ }^{32}$ Two brycg names, Handbridge and Bracebridge, are on the edges of Roman towns, the former over the Dee at Chester and the latter over the Witham at Lincoln. Brushford DEV, 'ford by a bridge', is on the line of the route between Exeter and Barnstaple, which, by its very directness, has often been suggested as Roman, for example by Margary. ${ }^{33}$ Bridgnorth, Handbridge and Bracebridge being over major rivers may well have referred to Roman bridges, no traces of which have yet been found. The others, over smaller streams, could well have been built by the Anglo-Saxons.

Regarding bridges not associated with Roman roads, the many examples in charter boundaries and in minor place-names occurring in the early post-Conquest period of Stockbridge (stocc, 'tree-trunk'), Thelbridge (thel, 'plank'), Risebridge (hris, 'brushwood'), Trowbridge (treow, 'tree'), Woodbridge (wudu, 'wood') and Felbridge (ON fjol, 'plank') give an impression of the numerous small wooden bridges or brushwood causeways that were constructed to link outlying parts of an estate with the settlement centre or to link neighbouring communities, saving pedestrians an icy-cold wade in winter - well worth commemorating in a name. An examination of the DB examples of these brycg names not associated with Roman roads shows that twenty-five were over watercourses that could be described as from small rivers upwards in size, and nineteen were over large streams downwards in size (as judged from the 1 inch O.S. map - an admittedly rough and ready assessment); the latter were not often on well-recognised and important route-ways. However, where a name commemorated what must have been a sizeable bridge over a substantial river, some of them tidal estuaries, there were sometimes important routeways. Examples are Tonbridge KNT, a crossing of the Medway on a north-south route Margary regards as Iron Age; ${ }^{34}$ Fordingbridge HMP, where a north-south route from Old Sarum to Hengistbury along the Avon valley crossed the river and where a possible Roman road through the New Forest from Stoney Cross to Fordingbridge also crossed, and Attlebridge NFK, at a crossing of the Wensum on a route leading west out of Norwich. The crossings of estuaries at Redbridge HMP, Stambridge ESX, and Bridgwater SOM, would have involved a causewayed approach to any bridge. The crossing of the Crouch

\footnotetext{
${ }^{28}$ Carroll and Parsons, Mint 1, fn. p. 67.

${ }^{29}$ pace DEPN, CDEPN and PN CAM.

${ }^{30}$ Jeremy Haslam, 'The Development and Topography of Saxon Cambridge', Proceedings of the Cambridge Antiquarian Society, 72 (1984), pp. 13-29; Atlas of Historic Towns, vol.2, ed. M.D. Lobel (London, 1975), pp. 1-3.

${ }^{31}$ N. Scarfe, Suffolk in the Middle Ages (Woodbridge, 1986), p. 141

${ }^{32}$ A.W.J. Houghton, 'The Roman Road from Greensforge through the Central Welsh March', Transactions of the Shropshire Archaeological Society, 56 (1961), pp. 1-17.

${ }^{33}$ Margary, Roman Roads, 1, p. 112.

${ }^{34}$ Margary, Roman Ways, p. 264.
} 
at North and South Fambridge, not bridged today, would have involved causeways across the marshes (the fenn of the name) each side of the river, probably leading to a ferry rather than a bridge.

For a bridge to have been worth building over a river (as opposed to a stream) in the early medieval period, and for a settlement to have been named from it by 1086 , suggests that the river must have been difficult or at least unpleasant to ford (deep, wide, no firm floor etc) and frequented by many travellers, and therefore on a well-used route-way. In contrast, many of the bridges over streams first appear as boundary points in Anglo-Saxon charters. Some of these survived to become settlement names and names of DB estates; a number of them indicate that they were simple wooden structures such as the Thel-and El-bridges ('plank'). These for the most part would have been for very local traffic and not useful as indicators of the national route-way network. It has been suggested that the three Brighams (brycg-hām), in NFK, YOE, $\mathrm{CMB}$, referred to early bridges since $h \bar{a} m$ ceased to be used in place-name formation after about $800 .^{35}$ Brigham YOE, is on a tiny island of higher ground in the marshes of Holderness and likely to have been reached by a causeway, but it is not on a Roman road. Brigham NFK is $11 / 2$ miles from where the Peddars way crosses the river Thet, while Brigham CMB lies close to the supposed course of the M 752 Papcastle to Moresby road and could refer to the Roman crossing of the Derwent.

Examples of $b r y c g$, then, have only a limited use in identifying the early medieval route-way network. To be useful they should be recorded in DB or earlier and be on the line of a Roman road, or else be over substantial rivers where bridge-building would have been a major undertaking, and not to be contemplated unless there was an urgent need on a busy route where fording was an unattractive alternative. The many little wooden bridges over small streams which were relatively easy to ford and served only a small area, are of no help in reconstructing the main route-way network. Brycg is a term that must be used selectively.

The fording-place terms are either so widespread, like ford and vath, that they occur on routes of all degrees of importance and so cannot be used to select out only the main routeway network, or they are so specialised that they refer only to crossings posing particular problems, and as such are less likely to be on major routes. Even with these limitations they can be of some use. The strēt-fords on Roman roads are good indicators of routes in use. Other ford names, while not identifying the route as part of the network, may help to confirm that it was in use and indicate the nature of the crossing; the gewaeds often represent the only or main crossing to an island or a short cut, while the geläds give warning of roads which are liable to flood, knowledge which is important to any traveller. The rare fording-place terms foer and sarn, while not widely applicable, are significant where they occur, but perhaps surprisingly, the British term ritu is much less helpful and should be used only as confirmatory evidence. The two terms for ferry, ON ferja and Latin traiectus, very sparingly used, are for crossings which are likely to have been very important links in the routeway network. A crossing with a bridge must have been a welcome alternative to a ford, but brycg has to be used with caution when identifying the routeway network since only the examples referring to crossings of substantial rivers and evidenced by DB are likely to be on important early medieval routes, except in the northern-most counties where the absence of DB coverage means that dates of first evidencing are likely to be later; most of them are much later, and refer only to crossings of small streams.

\footnotetext{
${ }^{35}$ Gelling and Cole, Landscape, p. 67.
} 


\section{CHAPTER 5}

\section{FACILITIES EN ROUTE}

The road and crossing-place terms give the traveller some useful information about the nature of the route-way, but if he ${ }^{1}$ is travelling for more than a day, he and his animals will need other provision. Probably the most important is water, especially in hot weather. It would clearly be impractical to carry enough water for several days for man and beast; cattle, for instance, drink around 30 gallons a day each. The more water that has to be carried the less the payload can be on a pack-train or cart.

Then there is a need for food for the traveller and his beasts. On a long journey the traveller may need to replenish his stocks or purchase meals. The animals can graze by the roadside, but if the route is well-used by many animals the grazing could run short, especially in winter. If fodder - hay - was obtainable en route that could be helpful.

The traveller himself would need somewhere to spend the night. He might well camp by the wayside, and probably do so by a source of water. In cold, wet weather the shelter of a building would be enticing. Provision of such a facility not only benefits the traveller but also the community providing it: it brings extra income, and also less tangible benefits like news and new ideas from afar.

The provision of water, food and shelter does much to ease the journey of the traveller, and may be sufficient for his needs in good conditions - agreeable weather and good roads - but conditions are not good always and everywhere. A spell of very wet weather can turn rivers into raging torrents and floodplains into lakes, while roads over claylands can become morasses. Daniel Defoe noted that in Sussex in 1742 a team of 22 oxen were unable to haul a tree to Chatham across the Weald 'for once the rains come in it stirs no more that year' ${ }^{2}$ Another difficulty besetting travellers with wheeled vehicles is a steep gradient. In areas where they are the norm the means of travel would be adapted to local conditions, but on a long journey with only occasional steep stretches wheeled vehicles might be the best and most economic method of transport, so long as there was provision for assistance on these steep slopes: extra draught power for teams struggling up the hill, or a winch to prevent loads careering downhill too fast, for instance.

Several corpora of place-names that occur consistently by routeways apparently indicate the provision of these facilities for travellers: certain of the mere names, some spring terms, the strōet-tüns, the caldecots, probably the mōr-tüns, the drag-tüns and drag-cots, and possibly the windlesoras. If these places have nothing to do with the provision of facilities for the traveller it is difficult to see why they should be so consistently associated with routes and be so rare elsewhere.

\section{WATER SUPPLY ALONG ROUTEWAYS.}

Water can be obtained from ponds, lakes, springs, streams and rivers.

\section{a) MERE}

The OE term mere was normally used by the Anglo-Saxons to describe a body of standing water of any size, but there are occasional exceptions to this. Mersea refers to an area of sea, and several examples, e.g. Sturmer ESX and Tadmarton OXF, refer to flood-prone portions

\footnotetext{
${ }^{1}$ Remembering that the travellers are not necessarily all male in spite of the use of 'he, him, his'

${ }^{2}$ Daniel Defoe, A Tour through England and Wales, 2 vols (London, 1948), 1, pp. 128-9.
} 
of rivers. The more usual term for pools connected to moving water is pól, pull, pyll, but this has no correlation with routeways.

The element mere was discussed by Cole in two articles, ${ }^{3}$ in which an attempt was made to classify meres according to their origins; a group in the Lake District (Buttermere,

Windermere etc) are ribbon lakes and a group in Shropshire and Cheshire are kettle lakes both groups of glacial origin (Ellesmere, Colemere etc); a group in Norfolk are probably periglacial features, but there are no early spellings available for these. Mere is also used to describe natural hollows where lakes collect, notably Fowlmere CAM and Fowlmere BUC, and Martin and Marton Meres in LNC. Yet others describe marshy hollows and seasonally flooded wetland. However, there are many, especially among the minor names, which refer to man-made ponds, and these tend to be considerably smaller than the natural meres.

A mere can provide a settlement with valuable resources, especially if it is large enough to support fish and wildfowl. The margins may yield reeds and rushes for thatching and bedding, or osiers for basketry and hurdles, and some may be surrounded by rich grazing. In dry chalk and limestone country the pond is often the sole water supply. Where the pond adds significantly to the settlement's well-being it may be commemorated in the place-name and become known far afield. However, vast numbers of village ponds are not thus 'advertised' in the name.

Of concern here is the part played by the settlements whose names incorporate mere in serving the needs of travellers. The mere corpus may be divided into four, listed in figs 5.1, 5.2, 5.3 and 5.4.

Firstly, mere as a simplex name: there are 19 whose sites are known, of which eight are recorded by $\mathrm{DB}$. Their distances from Roman roads are shown in the dispersion graph: fig. 5.5. A median of 2 miles and an inter-quartile range of $4 \frac{1}{2}$, suggests there is no correlation with the Roman road system.

Secondly, there are 15 examples where mere is the qualifier of an element other than tün. The distribution with respect to the Roman road system is again random, with a median of $23 / 4$ and an inter-quartile range of over 5 miles.

Thirdly, there are about 39 possible examples of mere-tün. The corpus listed in Cole 1992 has been revised to include Cold Martin NTB and Martin in Drewsteignton DEV, missed the first time. Martin HMP and Marton in Sewerby YOE have been excluded, as they probably refer to boundaries (gemcere): Martin HMP has no pond and is adjacent to Bokerly Dyke, a defensive earthwork thrown up in Roman times, ${ }^{4}$ while Marton YOE is near Danes' Dyke which crosses Flamborough Head. There are three Martons in YON (Marton in Sinnington, Marton in Cleveland, and Marton in the Forest) whose derivation is uncertain. Smith and Watts favour ON marr (marshy ground) while Ekwall and Gelling favour mere. ${ }^{5}$ Marton le Moor also falls into this category but is not listed in Watts. These four, along with Throckmorton, which may be a specialised term, have all been excluded from the statistics. The term for a 'mare' in place-names is thought to be very rare and unlikely to occur in this context since the names for most farm animals are not commonly combined with tün.

This leaves a core of 34 mere-tüns for which there are early spellings. The dispersion graph (fig. 5.5) contrasts with that of the previous two categories, having a median of $1 \frac{1}{8}$ and an inter-quartile range of $1 \frac{1}{2}$ miles indicating a distinct clustering near Roman and other old routeways. There are seven examples which are distant from Roman roads: Merton in north-

\footnotetext{
${ }^{3}$ Cole, mere-tūn', pp. 30-4l; Ann Cole, 'The Distribution and Use of mere as a Generic in Place-Names', JEPNS, 25 (1993), pp. 38-50.

${ }^{4}$ Christopher Taylor, Dorset (London, 1970), pp. 42-3

${ }^{5}$ PN. YON, pp. 76, 162, 28; CDEPN, s.n. Marton; DEPN, s.n. Marton; Gelling and Cole, Landscape, p. 26.
} 
western Devon, where there are no known Roman roads, refers to a large area of marshy land also noted in the name Marland nearby; Martin LIN, adjacent to the marshland bordering the river Witham; Martin near Ormskirk LNC, adjacent to the once extensive Martin Mere: two in Shropshire and Marten Farm KNT, which lies in Romney Marsh; all these derive benefit from nearby marsh and pools. Martin in Dalton-in-Furness LNC has only small pools nearby and it is not clear how Martin benefits from them. At least the first six of these mere-tüns do not need to be near to route-ways to derive benefit from their pools (the seventh is debatable). There are thus at least 27 mere-tüns which might derive benefit from proximity to routeways. Some have large natural meres, but many have only small village ponds which could yield little more than drinking water; however, this is a valuable commodity for anyone travelling with animals which would need to be watered regularly. Mere-tüns are likely to have become stopping places on route-ways. Whether the inhabitants provided more than water is unknown, but provision of food and shelter would be a natural follow-on and could benefit both parties.

Mere-tūn is therefore a useful indicator of a Roman road in use at the time of naming. The consistent way in which the term mere-tūn is used alongside Roman roads suggests a countrywide understanding of just what the name implied, just as other topographical placename elements are used consistently throughout Anglo-Saxon England. How this uniformity of meaning came about throughout the various kingdoms is uncertain, although people moving frequently over long distances must have played a role in unifying the terminology of roadside landmarks and settlements (see pp. 13-20). A very high proportion of the mere-tüns is mentioned in DB or earlier, or they are parishes. The three exceptions are two in KNT, and one in NTB.

The fourth category, that of mere used as a generic, is much larger. The ponds recorded in the many post-Conquest minor names supplied farmsteads and small hamlets like those described in the Chilterns by Cole, ${ }^{6}$ and need not concern us here. The distribution graph shows the distances from Roman roads and ancient tracks of the 75 major names. Although the distribution appears random, with a median of 2 and the inter-quartile range of $31 / 2 \mathrm{miles}$, there is a sub-group of these names which is closely related to routes. The O.S. Map of Roman Britain, upon which the measurements of distances are based, in fact shows only two long ancient tracks, the lcknield Way/ Ridgeway and the Harroway, and four short stretches, but there are other tracks often regarded as being ancient, for instance the herepceths and the North Hampshire Ridgeway, as well as a number of Roman roads described by Margary and others which do not appear on the O.S. map, some of which are described as Romanised ridgeways; M 542 and M 544 between Bath and Cirencester, M 811 across the Yorkshire Wolds from Fridaythorpe to Bridlington, and Old Street across the Berkshire Downs from Ginge to Winterbourne are particularly relevant here. Twenty-four major meres occur in chalk country, the ponds usually built on the superficial deposit of Clay-with-Flints, which is easier to make water-tight than chalk itself. These can be the sole source of water for many miles. Most of the -meres are within 1 mile of one of these lesser-known (Romanised) ridgeways or minor (i.e. non-O.S. map) Roman roads. Their dispersion graph can be seen in fig. 5.5: the median of $3 / 4$ mile and the inter-quartile range of $17 / 8$ miles resembles that of the mere-tüns. In other words, the major mere names in chalk country are good indicators of routes in use. The situation of Imber on the Great Ridgeway, 3 miles from any other water source, and the strategic position of Ashmore DOR, close to both a Roman road and the Great Ridgeway, highlights the importance of their ponds not only to allow the settlement to develop but also to supply passing traffic (fig. 8.5). Their names would be known far and wide amongst travellers, and their local importance (with little nearby competition) would

\footnotetext{
${ }^{6}$ Cole, mere, pp. $38-50$
} 
ensure that they became 'central places' and likely to develop into DB estates or parishes. It is probable that many originated in Romano-British or earlier times. Excavation by Toms ${ }^{7}$ has revealed Roman artefacts lying on the deposits at the bottom of ponds in the Sussex downland. Ringmere Pond DOR, is clearly integral with the Iron Age settlement on Turnworth Down, adjacent to the Harroway. O.G.S. Crawford ${ }^{8}$ suggested that some of the villages centred on downland ponds went back to Romano-British times, because of their association with Romano-British settlements, and the likelihood that the ponds were already a feature of the landscape when the Anglo-Saxons settled there or they would not have been given mere names. It therefore seems likely that the downland ponds by which passed the prehistoric tracks were already serving the needs of travellers before the advent of the AngloSaxons. Therefore, this group of mere names is very useful in identifying routes-in-use in addition to those shown on the O.S. Map of Roman Britain (see map: fig. 5.6).

An interesting group of mere names occurs in the chalklands of north-west Norfolk. In addition to Anmer, Barmer, Southmere (now Summerfields) and Egmere, all in DEPN, spellings are available for Shammer which is at a crossroads where the north-south route leads to the coast at Burnham and a Roman road passes east-west 11/2 miles to the south; the pond bears all the hallmarks of a really old man-made pond like the other meres on chalk. No early spellings are available for Cranmer Park on a Roman road, M 39, where it is crossed by an east-west route. Inmere has a deep pond and lies beside the Icknield Way at a cross roads, but it was called Needless Barn on first edition of the O.S. map, and so may be a recent invention.

Five examples, Rodmarton, Didmarton, Tormarton, Farmington GLO, and Tadmarton OXF, are unusual because they are made up not of the usual two but of three elements. From the position of Rodmarton, Didmarton and Tormarton on what is probably a Romanised old route it seems possible that they originated as 'element + mere' formations typical of those in waterless country on ancient tracks, and only subsequently had $t \bar{n}$ added because the track was recognised as being an important routeway. Perhaps this happened at the time when mere-tūn was being established as the appropriate name for this type of functional tün. Farmington, on a salt route, may have the same history, but it is not clear why Tadmarton should be so formed. Alternatively it may just have been a local fashion in naming. If meretün was established as an informative place-name formation well after the advent of the Anglo-Saxons ( $t \bar{u} n$ was more frequently used in later than earlier times), the settlements so called must have had earlier names now lost to us, unless cases like Rodmarton and Didmarton are indicative of a stage in the progress of a name from 'element + mere' to 'element+mere+tūn' to 'mere+tūn'.

A second source of water is from springs, and there are five $\mathrm{OE}$ terms and one $\mathrm{ON}$ term describing them.

b) WELLE

Wiell, well $(-a,-e)$, will, wyll $(-a,-e)$, wall, $\mathrm{OE}$, 'spring' or occasionally 'stream' is by far the most common. Plotting major wiell names on a simple geological map (fig. 5.7) shows that many are associated with the spring-lines along the scarp-foot of the chalk outcrops, especially the Chilterns and Lincoln Wolds. In the Cotswold Limestone, because the limestone is inter-bedded with clays, the springs occur within the hills as well as on the margins. Fewer welle names occur on the northernmost outcrops of the Carboniferous Limestone where ON kelda is used. South-east England and the Hampshire Basin lack major welle names except for the cluster of three in eastern Kent; in these areas $\bar{e} w i e l l$ and $\bar{e} w i e l m$ are most frequently found. Welle shows no particular correlation with Roman roads, but

\footnotetext{
${ }^{7}$ H.S. Toms wrote a series of articles on ancient ponds near Cissbury, Patcham and Falmer in Sussex Comnty Magazine, vol. 1 ( Aug. 1927), vol. 8 (Aug., Sept., Nov. 1934).

${ }^{8}$ O.G.S. Crawford, Archaeology in the Field (London, 1953), ch. 11
} 
where, coincidentally, a Roman road did pass close by a welle-named settlement the travellers would be aware of the source of fresh water.

There is, however, one small sub-group of welle names which occurs close to route-ways: these are the 11 byden-welles to which should possibly be added the three byden-funtas (see below under funta, and fig.5.8).

Alex Rumble ${ }^{9}$ discussed the first element of Bedfont MDX, Bedmond HRT, and Bedford Well SSX (all funtas) and concluded that it derived from OE byden, 'a tub or vessel'. He mentioned and listed nine byden-welles in the same context, although in fact there are 11 examples. His views concurred with those of Smith and Gelling: ${ }^{10}$ the names can be interpreted as 'spring with a vessel'. An examination of the geology of these sites suggests that the springs had only a very modest flow of water. If a collecting vessel was put under the spring it could collect the drips ready for use when required. The settlements by these places variously called Bidwell, Bedwell, Beardwell are all very small: three hamlets, seven farms and one country house today. None are recorded in $\mathrm{DB}$, but the term occurs in the charter bounds of 775-8 ( $11^{\text {th }}$ century) at Tetbury Upton GLO (also as a field-name in 1630), and of 950 at Wick and Abson GLO. ${ }^{11}$ When the 11 byden-welles are plotted on a map of Roman roads a close correlation is evident (see map, fig. 5.9, dispersion graph, fig. 5.10, and list, fig. 5.8). Bedwell and Bedwell Plash, although $1 \frac{1}{2}$ miles from a major Roman road, are only $1 / 4$ mile from a minor one, M 220, described by the Viatores. ${ }^{12}$ Biddles Farm BUC, now engulfed in Slough, was not near a Roman road, but it was only about $1 / 2$ mile from a Gough route, now the A4 (London-Bristol), which has several other place-names nearby suggesting it was an old route.

In spite of the close correlation of the byden-welles and byden-funtas with Roman roads, and in the West Country with old routes, many of the settlements so named are not actually on the roadside where travellers could take advantage of any water-trough, but as these water-troughs would already be well-known, a nearby settlement might acquire a name describing its location as 'the place near the spring with a trough'. Rumble ${ }^{13}$ calls attention to a passage in Bede about the provision of water for travellers by King Edwin of Northumbria:

'So much did the same king [Edwin] consider the comfort of his people that

in many places where he observed clear springs near to public cross-roads there

for the refreshment of travellers, posts having been erected, he ordered bronze drinking-vessels to be hung'

In the OE translation of Bede's Latin version springs (fontes) are glossed as wallan and public cross-roads (publicos uiarum transitus) as stratum, which fits very well with the occurrence of byden-welles by Roman roads - strēts. Although none of the byden-welles are in Northumbria, providing water for travellers was seemingly an appropriate thing to do; thus the byden-welles can be useful indicators of a road in use.

c) $\bar{E} W I E L L, \bar{E} W I E L M$

The second and third terms for springs are $\bar{a} w i e l l$ and $\bar{e} w i e l m$, listed in fig. 5.11. It does not seem to be possible to distinguish between them in the field. They are found mainly in southern and south-eastern England and describe springs with a copious flow of water. ${ }^{14}$ Parsons and Styles ${ }^{15}$ note that the terms probably derive from aeweallan 'to well up, gush

\footnotetext{
${ }^{9}$ Alex Rumble, 'A Bedan Gloss on Bedfont, Bedwell etc', Nomina, 12 (1988-9), pp. 123-30

${ }^{10}$ Smith, Elements, 1, p. 72; Gelling, Signposts, p. 86.

${ }^{11} \mathrm{~S} 145$ and S553.

${ }^{12}$ Viatores, Roman Roads, pp. 185-201

${ }^{13}$ Rumble, Bedan, p. 126.

${ }^{14}$ Ann Cole, 'Topography, Hydrology and Place-Names in the Chalklands of Southem England: funta, aewiell and awielm', Nomina, 9 (1985), pp. 3-19.

${ }^{15}$ David Parsons and Tania Styles (ed.), The Vocabulary of English Place-Names: $A$-Box (Nottingham, 1997), p. 35.
} 
forth', but there may sometimes have been an association with $\bar{e} a$, 'river'. These two shades of meaning are entirely compatible; the copious flow of water can produce an almost riversized stream (that at Oughton Head HRT, for example). In other places clear, artesian water bubbles up through the chalky floor of ponds, sweeps aside the mud and exposes a pale turquoise coloured floor, e.g. those at Alton Barnes and Priors.

The geological conditions that give rise to these copious springs are, first, an aquifer extensive enough to hold a large volume of ground-water such as chalk; second, a sufficiently fractured rock to allow easy passage of ground-water (anticlines are particularly good); and third, a steep hydraulic gradient (the surface of the water table should be steeply inclined), unlikely where the rocks are much fractured. Springs on the western part of the dip-slope of the North Downs are caused by different conditions - the Chalk is partially capped by later deposits causing many springs, some artesian, occur.

The map (fig. 5.12) shows the relationship between the $\bar{x} w i e l l s, \bar{x} w i e l m s$ and funtas and the geology of south-east England. There is a close association with the margins of the Chalk: Ewelme and Oughton Head with the Chiltern scarp-foot. Newelm SSX, is the only surviving $\bar{e} w i e l l / \bar{e} w i e l m$ name near the South Downs scarp foot as the chalk is so fractured that only under Beddington Hill is the hydraulic gradient great enough to produce a copious spring. Four breached anticlines are shown; the Pewsey anticline has Alton Barnes and Priors, and Urchfont, at the foot of its inward-facing scarps. The Wardour anticline has three funtas, Teffont, Fovant and Fonthill similarly positioned; the Portsdown anticline has Fontley, Boarhunt and Havant; and the Stocksbridge anticline has Alton. The springs at Ewen GLO, near the source of the Thames, are associated with the Oolitic Limestone, and Aldon SHR with the Aymestry Limestone. Further details can be found in Cole. ${ }^{16}$ There are more examples of $\bar{e}$ wiell and $\tilde{e} w i e l m$ in charter-boundaries in the same sort of situations, notably at the foot of the Berkshire Downs at Ginge, West Woolstone BRK and Liddington WLT. ${ }^{77}$ The Icknield Way and Port Way run along the foot of the Chilterns and Berkshire Downs and so pass through or very close to these spring-side settlements, while the Great Ridgeway runs along the crest of the Downs at the top of the scarp slope; in Dorset, Alton Pancras and Toller Whelme both lie within 1 mile of the Great Ridgeway. Aldon SHR, also lies on a route - a weg which climbs steeply up and over View Edge (weg-hōh). There is actually a good correlation between $\bar{e} w e i l l s, \bar{c} w i e l m s$ and old routes and Roman roads. It could be argued that the correlation with old routes, especially the Icknield Way and Great Ridgeway, is an accident of geology, the long-distance routes following the dry slopes or crest of the Chalk while the springs emerge at its foot. However, there are other juxtapositions to consider: Ewell near Dover, Ewell near Faversham and Ewell near Kelvedon are very close to Roman roads, while Awell Barn SSX, which only appears in the records in 1526 and does not have as strong a spring as most, is only $1 / 2$ mile from a Roman road: none of these are scarp foot settlements.

The dispersion graph (fig. 5.10) shows a concentration of names within 1 mile of a Roman road or old route, having a median value of $3 / 4$ mile. The inter-quartile range is 2.0 .

Allowance has been made for Coundon WAR, the settlement most distant (seven miles) from any route on the O.S. map of Roman Britain, because it is only $3 / 4$ mile from the Ogilby route discussed under Alspath (vol. 2, p.184). Meriden, formerly Alspath, was the site of a Roman fort on this route, which may therefore have been a Roman road. When Coundon is plotted as $3 / 4$ mile from a route the inter-quartile range is $1 \frac{5}{8}$ mile, indicating a good degree of clustering, so much so that routes should be sought near other settlements which lie more than about $11 \frac{2}{2}$ miles from the O.S. map routes. For instance, Newell, Orpington KNT, lies at

\footnotetext{
${ }^{16}$ Cole, Topography: funta, pp. 3-19.

${ }^{17}$ I am grateful to Joy Jenkyns for a computer print-out of these charter boundary forms in 1988
} 
the head of the Cray valley which has a string of Roman villas along it, but is $5 \frac{1}{2}$ miles from the nearest O.S. map Roman road; these villas must surely have been linked by a road, in which case Newell would have been very close to it. As there are only 20 examples the chisquared test is barely applicable to this corpus, but when it is applied at $11 / 2$ miles the resulting figure of 20.12 indicates a chance of less than 1 in 1,000 that the distribution with respect to Roman roads and ancient tracks is random. However, this does not take into account the fact that the geological conditions producing the springs can also have an effect on the routes of the ancient tracks.

There appears to have been a mixture of naming practices: the usual one was to refer to a copious spring as an $\bar{e} w i e l l$ or $\bar{\alpha} w i e l m$, but sometimes a lesser spring on a route-way was called by one of these terms. In either event the result is the same; it informs any traveller of a good, clean source of water nearby, one ordinarily so copious that it will still be flowing even in drought years. $\bar{E}$ wiell and $\bar{e} w i e l m$ are normally good indicators of routes nearby, and can be used as supporting evidence that they are in use (see map: fig. 5.14).

\section{d) FUNTA}

The fourth spring term to consider is funta. This is thought to have been borrowed from the Latin fons, fontis or from late Latin fontana into $\mathrm{OE}^{18}$ This has given rise to 21 names in funta. The Latin word is also thought to have been adopted by British speakers and used in naming Fonthill WLT and Fontmell DOR, which are British rather than OE names. To account for the Anglo-Saxons using a Latin term for a spring rather than OE one Gelling ${ }^{19}$ suggested that the springs were in some way Romanised, perhaps by having some masonry built around them (see map: fig. 5.14).

The article by Cole in 1985 discussed the springs named funta, but, contrary to what was said, there is a good spring at Bedmond HRT, and there are two further examples to add: Bonhunt HRT and Funtington SSX; both have prolific springs (see list, fig. 5.13).

The dispersion graph (fig. 5.10) shows a similar correlation with Roman roads and old routes as does the $\bar{e} w i e l l$ and $\bar{e} w i e l m$ graph: the median of 1 and the inter-quartile range of $11 / 2$ miles indicate much the same degree of clustering. The chi-squared test at $11 / 2$ miles indicates a chance of between 1 in 100 and 1 in 1,000 that the distribution is not random, a warning to be somewhat cautious in drawing any conclusion. It is not known if the funtas were deliberately sited by roadsides for the use of travellers, or if they were often by roadsides because, like many other Roman constructions, they were served by the road network. A funta may have been a feature of Roman settlements such as villas served only by minor, local roads, and this could account for the slightly greater numbers more than about 1 mile from a Roman road. A traveller would not want to divert more than about 1 to $1 \frac{1}{2}$ miles from his route especially if he is on foot, so a funta further than this from a Roman road is not normally going to be of use to a traveller unless it is the only source of water nearby -as might be the case with Urchfont, Teffont and Fovant below downland ridgeways.

Funta is therefore a less reliable indicator of routes in use. However, if places such as Bonhunt and Tolleshunt are ever found to be near hitherto unrecognised routes, the situation may have to be reconsidered. Two of the byden-funtas (Bedfont MDX, and Bedmond HRT) are on Roman roads like their counterparts the byden-welles (above, pp. 57).

The remaining terms for springs are ON kelda, which bears no relationship to Roman roads and $\mathrm{OE}$ celde of which only three examples are known: too few to be useful. e) $B R \bar{O} C, B U R N A, \bar{E} A$

A third source of water is from streams and rivers. Brōc and burna are widely used to describe streams larger than a gentle trickle and smaller than a full-blown river. There is no

\footnotetext{
${ }^{18}$ Gelling and Cole, Landscape, p. 17

${ }^{19}$ Gelling, Signposts, p. 86.
} 
correlation with old route-ways, but now and again by chance a route will pass through a burna, e.g. Medbourne LEI, or a $b r \bar{c} c$, e.g. Rushbrooke SFK. They are no use in identifying routes.

$\bar{E} a$ is the term used for a large river, but is rare as a generic in settlement names. However, it is quite often compounded with tün when it is of significance to water-borne traffic, and this is considered in chapter 6.

In conclusion, mere-tün, 'element + mere' in chalk country, byden-welle, $\vec{e} w i e l l$ and $\bar{a} w i e l m$, and just possibly funta can be of help in identifying routes in use. They would be known to travellers as sources of water and places to pause for a rest if not an overnight halt.

\section{LODGINGS EN ROUTE}

Any travellers on a journey of more than one day are likely to want, in addition to water, food and a place to stay overnight. They might choose to camp by the wayside or sleep under the stars as the drovers sometimes did, but in cold, wet weather a water-tight, windproof building would be very enticing. If the traveller was well-to-do he or she would probably have stayed in a building anyway.

\section{a) STRËT-TÜN}

Is it possible that something akin to the Roman roadside settlements, built at regular intervals along the roads to serve the military in the first instance and later the ordinary traveller, existed in Anglo-Saxon England? If it did, and if there was a place-name that indicated a place with such a function, then strēt-tün would be a strong contender. One would expect these places to be regularly spaced along the most used route-ways, perhaps a day's journey apart, although this is a variable figure depending on the mode of transport and the nature of the terrain. The strâtt-tüns (fig. 2.2) are certainly not as evenly spaced as this, but there are two routes with fairly regular spacing - the Fosse Way and the route along the Welsh Marches. Where the strēt-tüns are rather too far apart for the convenience of travellers there are sometimes ceasters between them. The ruined stone buildings of these old Roman towns were good landmarks and easily recognised by any traveller. They would have offered overnight lodging in Roman times. If they, too, had inhabitants offering hospitality in the Anglo-Saxon period, then between them the strät-tüns and the ceasters might offer a chain of overnight stopping places manageable distances apart. Typically these distances are 7 miles or multiples of 7, and 11-12 miles or multiples thereof (a waggon would average about 11 miles a day).

The distances between the strât-tüns and ceasters along the Fosse way are approximately: Over Stratton - Ilchester 7 miles

Ilchester - Street on the Fosse 12 miles (is 'Street' used to avoid confusion with nearby Stratton?)

Street on the Fosse - Stratton on the Fosse $71 / 2$ miles

Stratton on the Fosse - Bath 10 miles (well-known Roman town)

Bath - Cirencester 29 miles (the Fosse Way may not have been in use along this stretch)

Cirencester - Stretton on Fosse 261/2 miles

Stretton on Fosse - Stretton on Dunsmore $24 \frac{1}{2}$ miles

Stretton on Dunsmore - Stretton under Fosse $6 \frac{1 / 2}{2}$ miles

Stretton under Fosse - Stretton Baskerville via High Cross 8 miles (High Cross is a major cross roads with Watling Street)

The distances between the strët-tüns and ceasters along the road from the south midlands (Wanborough near Swindon) to the Welsh Marches, and along the Marches to Chester are: Stratton St Margaret - Stratton (near Cirencester) 14 miles

Stratton-Gloucester 151/2 miles

Gloucester - Stretton Grandison c. 20 miles 
Stretton Grandison - Stretton Sugwas 11 miles

Stretton Sugwas - Leintwardine (site of a Roman settlement) 20 miles

Leintwardine - Church Stretton 13 miles

Church Stretton - Wroxeter 12 miles

Wroxeter - Whitchurch (site of a Roman settlement) 20 miles

Whitchurch - Stretton 9 miles

Stretton-Chester 9 miles.

Although a typical minimum distance between these places is about 7 miles there are clearly far greater distances separating some of them. In the case of the Fosse Way there is some place-name evidence to suggest that the stretch between Bath and Cirencester was not in use, but between Cirencester and Stretton on Dunsmore there must have been opportunities for overnight stays at places with some other name(s). This is further explored in Chapter 9 Synthesis. In the case of the Welsh Marches, from Stretton Sugwas to Church Stretton is 23 miles but the road passes through Bravonium now Leintwardine on the way: might this once have had a ceaster name?

Further north, the distance between Wroxeter and Stratton (near Chester) is 29 miles. The road passes through Whitchurch, the site of Roman Mediolanum. Whitchurch would not have been an early $\mathrm{OE}$ name since church buildings of the nature implied here did not exist in the earliest Anglo-Saxon centuries: did Whitchurch once have a ceaster name? Even allowing for the possible re-routing of part of the Fosse Way and re-naming of Leintwardine and Whitchurch (which could be seen as special pleading) there would still be unacceptably long distances between some of the strēt-tüns and ceasters for providing a comprehensive network of overnight lodgings on these two routes.

There are not nearly enough strēet-tüns to provide a comprehensive network of facilities such as overnight lodgings on the roads, so other corpora of place-names need to be considered for this function - some of the meres for instance. In fact two mere-tüns, Merton SRY, and Marton LIN, are on the sites of Roman roadside settlements, as though they had for centuries been convenient places to stop: an appropriate distance from the previous place, and one with water available. Two of the strēt-tüns, Stretton Bridge STF and Long Stratton NFK, are also the sites of Roman roadside settlements. ${ }^{20}$ The sträet-tüns, though much further apart, may have performed a similar function in Anglo-Saxon England, providing travellers with food, lodging and a place for their animals. Given the parallels with other names now recognised as functional tüns the very choice of the name 'street settlement' (strēt-tün), indicates that the place had some special function related to the Roman roads. If they were not overnight stopping-places might they have been places responsible for the upkeep of the road in some way? There is no written evidence of any duties of road maintenance in AngloSaxon England (although the duty of bridge repair is well-known), ${ }^{21}$ and this has led to the idea that the Anglo-Saxons did not repair their roads. This seems very unlikely: even if there was no organised system for maintaining roads, anyone using a stretch of road regularly, e.g. for bringing in the harvest or for carting fuel wood to the homes, would be quite prepared for his own convenience to fill up the worst of the potholes or strew stones and brushwood on the muddiest patches. A possible example of this is instanced under hafocgeläd $\mathrm{OXF}$, adjacent to a stone quarry (see vol. 2, p. 188). If the strātt-tüns were responsible for road maintenance they would surely be found in places where the Roman roads would be most likely to founder such as the clay vales or the fen edge. However, they are not often found in places like this, but rather where the roads are on much firmer foundations such as on the

\footnotetext{
${ }^{20}$ Finch-Smith, Roadside, pp. 11-2.

${ }^{21}$ Stenton, Anglo-Saxon, pp. 289-90.
} 
limestones and sandstones, so it is more likely that the strät-tūns were overnight halts for travellers, possibly offering better facilities than the mere-tüns.

b) COLDHARBOUR and CALDECOT

Cold Harbour has repeatedly been said to occur beside Roman roads and to serve as a basic shelter from the elements; Caldecot is frequently included in these comments. The idea that Cold Harbour is a shelter beside a Roman road goes back at least to 1810 and has been repeated by, among others, Watkins, Margary, Addison, Bagshaw ${ }^{22}$ and more recently by Muir and Hindle ${ }^{23}$ in spite of several attempts to disprove the connection. Both Ogden and Coates $^{24}$ list earlier references to the idea.

Bonner, in the Place-Names of Surrey, ${ }^{25}$ says there are over 300 examples of Cold Harbour but only about 35 are within $1 / 2$ mile of a Roman road, and that 'the great majority have no relation to such roads'. Coates offers an explanation why the name was so infrequent before 1600 - only eight examples being known - but became so widespread afterwards: they were named after a notorious block of tenements by the riverside in London, built around 1590 and destroyed in the Great Fire of 1666. The lack of Cold Harbours recorded as far back as DB stands in stark contrast to the Caldecots ( 17 out of 58 recorded by DB) and other names considered in this study. The reason for the persistent myth appears to lie in comments by the Viatores in $1964 .^{26}$ They show that in BDF, BUC and HRT west of Ermine Street the percentages of Cold Harbours and Caldecots at certain distances from Roman roads are:

\begin{tabular}{|l|l|l|l|l|}
\hline & $0-1 / 2$ mile & $\frac{1 / 2-1 \text { mile }}{24}$ & $\frac{1-2 \text { miles }}{11}$ & $\frac{2+\text { miles }}{8}$ \\
Cold Harbour & 57 & 30 & 0 & 0 \\
Caldecot & 70 & 0 & 0 \\
\hline
\end{tabular}

and they conclude 'thus it is clearly demonstrated that in this region the names are not merely of common occurrence along the Roman roads, but are, in fact, to be clearly connected with such roads'. The key words are 'in this region'. This was the area in which the Viatores identified a network of minor Roman roads sufficiently dense for few areas to be more than two miles from a Roman road. The comments do not refer to the distribution elsewhere in England. Later authors seem to have taken the Viatores' comments to be applicable countrywide, although no such claim was made.

Ogden's paper of 1967 is a useful discussion of the problem. ${ }^{27}$ His method of testing the idea statistically is of particular interest because he uses a method similar to that used in this study, namely of working out the actual numbers of Cold Harbours within two, four and six miles of a Roman road, comparing them with the numbers expected if the distribution was random, and then applying the chi-squared test. His results give likelihoods of 1 in 20 to 1 in 200 , indicating some link with Roman roads, but not nearly so close as the links between the mere-tüns or the byden-welles and roads. As Ogden notes, two miles is a long diversion from a Roman road to seek a poor night's lodging and does not necessarily support the idea of a Cold Harbour being an overnight halt for travellers. Even if they were overnight stops, the

\footnotetext{
${ }^{22}$ Alfred Watkins, The Old Straight Track (London, 1974, first pub. 1925), pp. 76-7; Margary, Roman Ways, p. 27; William Addison, The Old Roads of England (London, 1980), p. 35; Bagshaw, Roman Roads, p. 21

${ }^{23}$ Muir, New, p. 102; Hindle, Roads and Tracks, p. 19

${ }^{24}$ T.R. Ogden, " "Coldharbours” and Roman Roads', Durham University Journal, 59 (1967), pp. 13-24; Richard Coates, 'Coldharbour - for the last time?', Nomina 8 (1984), pp.73-8.

${ }^{25}$ PN. SRY, pp. 406-10

${ }^{26}$ Viatores, Roman Roads, p. 351

27 Ogden, Coldharbours, pp. 13-24.
} 
correlation with Roman roads is not because the road was Roman but because the road was in use after 1600 and happened to be on the line of a Roman one. The evidence against Cold Harbour being an indicator of Roman roads in use in early medieval times is chiefly that the great majority of these names were given at a much later date, and long after the Roman road network had ceased to be the most important set of routes in use, and that not a high enough percentage is within one or two miles of the Roman road system. They are of no help in identifying the early medieval route-way network.

Caldecot has often been linked with Cold Harbour in identifying Roman roads, and as 17 of them occur in DB they are worth investigating (see map: fig. 5.16). A settlement called - $\cot (\mathrm{OE} \cot$ ) is likely to be made up of small, rather poor-quality dwellings - a cottage or a hovel - or sheds for particular activities like smithing (Smethcote) or housing animals such as swine (Swincotte). Dyer has identified a 'noticeable minority' that are close to towns, and linked to them through their economic activities. ${ }^{28}$ This still leaves large numbers of $c o t s$ amongst which there may be groups of functional cots, just as there are groups of functional tüns amongst the great mass of tūn names: possible examples are drceg-cot, mōr-cot, wuducot and calde-cot.

The prefix cald (cold) could be given to a cot in a variety of circumstances. The settlement might be in a very exposed situation: Chaldecots DOR, on the slopes of Swyre Head overlooking the Dorset coast and open to the south-westerly gales, is a prime example, while Cargo Fleet YON on the Tees estuary would catch the cold winds off the North Sea. Others are exposed because of their altitude: Coldicote and Calcot Farm are both on high open ground in the Cotswolds, both bleak and lonely places, Cold Cotes YOW is at $700 \mathrm{ft}$ near the upper margins of cultivation. Others will be found in the list of calde-cots in fig. 5.15. The chilliness might be due to dampness rather than altitude: the cold clagginess of a clay soil in winter could account for some of the calde-cot names of the East Midlands. Fourteen lie wholly and three partly on boulder clay; twelve on other clays, seven more are in low-lying, damp conditions close to rivers and their flood plains. A few face NE or NW. Some of these are comparatively isolated in their localities (see fig. 5.15 for a summary). Four-fifths of calde-cots are in cold situations as inferred from maps, however, one should try living there to experience what conditions are really like. Bailey makes the same points when discussing the Buckinghamshire calde-cots. ${ }^{29}$ Might calde-cot be anything more than a description of a poor cottage(s) in a cold situation? Cald in place-names is used frequently to describe springs (welle and kelda) and hills. Parsons and Styles are of the opinion that it means 'cold' - no more, no less. ${ }^{30}$ Regarding cot, there are over 870 listed in EPNS volumes of which about 200 are combined with a personal name; some 160 with North, South, East, West, Middle, Up(per) or Nether. There are recurring compounds with cot such as calde-cot (57 examples); wudu-cot (20); draeg-cot (16); mōr-cot (8); fox-cot (7) and owl-cot (7). It is reasonable to hypothesise that the wudu-cots, drceg-cots and perhaps the mōr-cots are examples of functional cots, but difficult to think of a function that could be fulfilled by a calde-cot - it may mean exactly what it says 'cold cottages'. ${ }^{31}$

One alternative explanation for the name Caldecot has been offered by Philip Tallon ${ }^{32}$ who, noting how many calde-cots lie close to county and other boundaries and have a royal connection, suggests that they may have been places of banishment. His list includes a number of places for which no early spellings are available and a few which probably derive

\footnotetext{
${ }^{28}$ Christopher Dyer, 'Towns and Cottages in Eleventh Century England', Studies in Medieval History, ed Henry Mayr-Harting and R.I. Moore (London, 1985), pp. 91-106.

${ }^{29}$ Keith Bailey, 'Place-names in -cot: the Buckinghamshire Evidence', JEPNS, 31 (1999), p. 80.

${ }^{30}$ Parsons and Styles, Vocabulary: Brace - Ceaster, pp. 127-30.

${ }^{31}$ Gillian Fellows-Jensen suggests it means 'unheated' cot (personal communication)

${ }^{32}$ Philip Tallon, 'What was a Caldecote?', JEPNS, 31 (1999), pp. 31-54
} 
from other elements, and these are not used in this discussion. He dismisses the idea that calde-cots may be wayside shelters, saying

' This topographical marginality may also be regarded as sufficient evidence for rejecting the generally accepted proposition that they were places which could provide shelter for travellers; they tend to be on the way to nowhere in particular and, in many instances, given their geographical location, they may be regarded as very much 'at the end of the line'. Why a distribution network of 70 settlements so far off the beaten track should be deliberately named Caldecote to indicate that shelter may be obtained there is difficult to imagine ...' and '... Some scholars have noted that there appears to be a correlation between the location of Caldecots and Roman roads; whilst this is true in almost half the instances, I do not consider this to be of any particular significance; such roads tend to be at least 3 or more miles distant ...'

Fig. 5.15 lists the safe examples of calde-cot and the distance they lie from Roman roads and other old routes. It shows that 42 of the 56 lie three miles or less from such a route (considerably over Tallon's half), and that 24 lie at one mile or less, not convincingly 'at the end of the line' or 'on the way to nowhere in particular'. Tallon does not give any information about the distances between individual calde-cots and Roman roads and as he includes a number of doubtful examples his comments are to be treated with caution.

The possibility that calde-cots are wayside shelters for travellers is often repeated uncritically, but applying the chi-squared test to the figures in fig. 5.15 yields results somewhat better than those for Cold Harbour, namely 22.73 at 1 mile, and 24.14 at 2 miles i.e. less than 1 chance in 1,000 that the distribution is random. All the chi-squared tests applied here are based on the Roman roads and ancient tracks shown on the O.S. Map of Roman Britain, and if only these routes are considered then many calde-cots are considerably more than about $1 \frac{1 / 2}{2}$ miles from a route (one would not wish to divert further from a route for just a poor night's lodging). However, there are various other Roman roads lately discovered or less firmly proven, salt ways, and old tracks such as those on Gough or Ogilby maps. About a dozen calde-cots are by these additional routes: for instance Caldecot RUT is on the line of M 571 from Medbourne to Great Casterton: Coldicote GLO (now Westfield) is 11/2 miles from a salt way and Calcot Farm GLO (in Newington Bagpath) is $3 / 4$ miles from both the M 542 and M 543. For further details see figs 5.15 and 5.16.

Thus it appears that the great majority of calde-cots are close to old route-ways, and that they can be used to confirm routes suspected to have been in use on other evidence; indeed, they are particularly useful in helping to identify these less well-recognised routes. On the other hand, it seems that not all calde-cots were on well-used old routes; that on Swyre Head, never can have been. It is clear that in many cases, if not all, there was some feature of the locality that made the cot seem bleak and/or isolated and earning it the prefix calde. It is clear too that the calde-cots were rarely thriving settlements: their $\mathrm{DB}$ values tended to be low, and of the 17 DB examples only two are villages today (RUT and SOM); the rest have shrunk to only a farm or hall with a (ruined) church (CAM, HNT, NFK and WAR), and others to just a hall or farmstead. Of the post-DB examples, many survive as farms or hamlets rather than villages or towns; a few have been absorbed into expanding towns (BRK and YOW), while others have disappeared from the landscape altogether. However, the impression of them in the minds of people, and especially travellers, must have been strong, and word passed among them that these places, while better than nothing, were not the most desirable of lodgings especially in winter with their cold, damp environment and poor-quality buildings There are at least four instances where it would seem that a traveller could take shelter at a calde-cot while waiting for floods to subside at a river-crossing. These are: Caulcott near Abingdon, where the Thames was liable to flood the proto-A34 (a Drayton lies 1 mile to the 
south); ${ }^{33}$ Caldecot WAR, two miles from where Watling Street crosses the Anker at Mancetter (Fenny Drayton lies a mile away); Caldecott RUT, by the flood-prone Welland, close to two places where Roman roads cross the river, and 21/4 miles from another Drayton; and Caldecot BDF, across the lvel from Biggleswade, itself a name indicating a difficult crossing which would have been impassable at times (see vol.2, p. 188). Where travellers approaching these crossings from the opposite direction might have stayed is unknown! This passing traffic may have brought just enough benefit to enable the place to survive, while most calde-cots away from routes did not. It may therefore be that at one time there was a denser scatter of calde-cots built in cold situations which were deserted before they ever crept into surviving written records. It was those known to and used by travellers which survived and whose names are known now, and while they may not have originated as roadside shelters that is what many developed into, combining it with their customary farming activities.

Until such time as any more plausible suggestions for coining the name Calde-cot and for examples to be so often near route-ways are made, this suggestion of them evolving into roadside shelters is the best that can be offered.

Therefore a traveller seeking overnight shelter is likely to have found it at a strōt-tūn alongside a Roman road, or at a calde-cot close to a Roman road or some other old route. Cold Harbour as a regular name indicating a wayfarer's shelter did not exist in early medieval times.

\section{FODDER FOR ANIMALS}

Early medieval farmers faced the problem of keeping their livestock through the winter months when grass growth had slowed, and in most areas stopped, with falling temperatures. Hay-making was therefore a very important part of farm work. Areas called 'mead' or 'meadow' indicate where the grass was traditionally gathered as a hay crop. Some parts of the countryside were much better suited for growing a hay crop than others, so some places suffered shortages and others had a surplus. In some cases estates had detached areas of meadow if the main part lacked meadowland: Blair mentions the case of Taynton with its riverside land at Northmoor. ${ }^{34}$ Thus there was a potential market for hay, although as a bulky commodity one would not wish to transport it far. Potential customers would be those estates which could not produce enough of their own; towns where draught, riding and milch animals might be kept, and the drovers and jaggers travelling the roads. The latter might find sufficient grazing by the wayside in summer, but not in winter when travel was inhibited for that very reason. They would benefit from knowing where hay could be obtained for consumption or as a load to be sold on, perhaps in the next town.

Place-names that could indicate hay production include moed, hèg, filithe, mōr and mersc. For any of these to have benefitted travellers in particular they would need, if possible, to have been known and used throughout England, and for a high proportion to bear a close relationship to busy routes. In view of the growing number of 'functional tüns' associated with routeways those elements frequently combined with tün are the more likely candidates. These five elements are considered in turn.

OE maed 'meadow, piece of meadowland kept for mowing' ${ }^{35}$ is common in post-Conquest minor names, but uncommon in DB, parish or township names, only 13 examples having been noted. There is one in WML (Meaburn), all the others are south of a line from Shropshire to the Wash, so they are hardly countrywide. About one quarter is within one mile of a Roman road, the Great Ridgeway or the Gough route from London to Cambridge, this is

\footnotetext{
${ }^{33}$ See below for the functions of the Draytons and Draycots.

${ }^{34}$ Blair, Oxfordshire, p. 130; S1068; PN.OXF, 2, p. 489.

${ }^{35}$ Smith, Elements, 2, p. 31.
} 
not a close correlation with old routes. None are combined with tün. Mced is therefore not a term likely to have been of particular use to travellers.

There are problems in distinguishing OE hegg, $h(i)$ eg 'hay' from OE (ge)hoeg 'fence, enclosure', hege 'hedge, fence' and hè $h$ 'high, high place' when it is the first element in ME spellings ( $h \bar{e} g$ is always a first element), ${ }^{36}$ therefore the corpus listed and mapped in figs 5.17 and 5.19 may be slightly inaccurate. Seemingly there are $14 \mathrm{DB}$, parish or township names in hèg (counting the two Upper and Lower Heyford pairs as one each), a very much higher proportion of the whole than in the case of maed. Some of the minor names listed in fig. 5.16 refer not to settlements, but to hills or enclosures. They are distributed much more widely than the maed names - from the Lake District to Devon, though scarce in the East Midlands, East Anglia and South-East England. Although a quarter of the examples is within half a mile of a Roman road or navigable river, this is too low a proportion to indicate a term of significance to travellers. There are five $h \bar{e} g-t \bar{u} n$ s, only about $12 \%$ of the whole. An analysis of the generics suggests that they either describe the place where the hay was grown or the routes along which it was moved from the hay meadows to a storage place. There are 16 hill terms ( $d \bar{u} n$ (10) and beorg (6) - the latter being drumlins in the north-west), nine clearings (leah (5) and thwaite (4)) and three crofts. Nine describe routes (ford (6), weg (2) and a gata). There are two denus and five tüns. Although people, travellers included, would understand that hay was produced in or near these places they would not be likely to associate the term with a place with a surplus for sale or exchange.

Names incorporating filithe, filethe 'hay' are not always easy to distinguish from those containing fealu 'fallow coloured', ${ }^{37}$ or ME feld, fellet. ${ }^{38}$ It is much less common than maed or hèg, only 16 examples having been noted and this is not a wholly reliable corpus. It appears to be restricted to the southern counties, being found in KNT, S.OXF, DOR, DEV, SOM, GLO, and HRE. See figs 5.18 and 5.19. With so few examples and such a limited distribution and because rather few of them are by routeways they would not be of use to drovers or jaggers seeking a source of hay. However, an analysis of their generics and of their locations suggests an interesting contrast to the hèg names. Filithe is combined with terms for hollows and wet places in seven instances (hamm (4), cumb (1), denu (2)) - perhaps the two fords should fall into this category, with lēah twice and with tün twice. In three instances it is a simplex term. It is notable that many of the filithes are in hollows with springs ( 10 of the 16) while three others are adjacent to rivers and two are well watered with streams. The site of the sixteenth example is unknown. This contrasts with he g which is often combined with a hill term and is much less frequently near a spring. The grasses and herbs in the two situations would have been recognisably different.

It remains to consider whether mōr and mersc indicate anything more than wet places, and whether they might produce hay crops attracting the attention of travellers. At this point it should be noted that mōr means 'marsh or barren upland' in place-names, although whether its original meaning is to do with 'wetness' or 'barrenness' is uncertain. ${ }^{39}$ In the majority of place-names it refers to wet or marshy areas. It appears as district names such as Otmoor, Dartmoor, Exmoor and Stainmore, and in names of settlements adjacent to such wet or barren areas. Mōr is widespread; the corpus includes 66 examples of mōr-tūn. Mersc is used to describe ill-drained land; used as a DB or parish/township name it is less common than $m \bar{o} r$. It is frequent in minor names of the type 'home of $\mathrm{x}$ at the marsh', and to describe a settlement's patch of marshland (e.g. Aslaby Marsh). Sometimes it is used of large areas of marshland, for instance 'The Marishes' referring to the Vale of Pickering; Henmarsh GLO,

\footnotetext{
${ }^{36}$ Smith, Elements, 1, p. 241.

${ }^{37}$ DEPN, s.n. Fawley.

${ }^{38}$ Smith, Elements, 1, p. 173.

${ }^{39}$ Gelling and Cole, Landscape, p. 58.
} 
referring to an ill-drained watershed around Moreton in Marsh, and the Vale of Marshwood DOR. Other names refer to coastal or estuarine marshland particularly along the Holderness bank of the Humber. There are 35 examples of mersc-tün (see lists: figs 5.20, 5.23, and maps: figs $5.21,5.24$ )

To return to the argument: mör and mersc are both widely used: in both cases they are frequently combined with $t \bar{u} n$ giving the possibility of them being functional tūns. It remains to consider whether they are normally places that can grow grass suitable for hay production, and if they correlate well with old routeways.

The sites and immediate surroundings can be examined by looking at large scale maps, noting relief, drainage and sometimes the marshland symbol but remembering that what was marsh in the early medieval period may have since been drained. A geological map will show if the area is likely to be ill-drained - clays and alluvium being the best indicators.

Settlements were rarely built on these if there was a patch of gravel or better-drained rock nearby. The important feature to note is whether the settlement was situated by a sizable patch of clay or alluvium or not. A soil map will indicate whether or not the soils are readily cultivable or better left under permanent grass. Figs 5.20 and 5.23 indicate the sort of results that can be obtained from noting the soils within about half a mile of each $m \bar{o} r$-tün and mersc-tün. Soils classified as in the 400 s are slowly permeable clayey soils (pelosols), in the 700 s are surface water gley soils, seasonally water-logged, slowly permeable, and in the $800 \mathrm{~s}$ are groundwater gleys developing on permeable soils with a seasonally high water table.

Soils in the 700s and 800s are best kept under permanent grass. Soils in the 500s group, the brown soils, are better-drained and generally suitable for cultivation. The results show that almost $80 \%$ of the mōr-tüns and mersc-tüns had some 400 s, 700 s or 800 s soil types nearby and that over $50 \%$ had some better drained 500 s soils upon which the settlement stood.

Both corpora of $m \bar{r} r$ and mersc are large. It is not the place here to discuss them in detail, but to refer to a few investigations that have already been done. Helen Maynard's belief that mersc referred to more tractable land than mōr in the Avon valley WAR, could not be substantiated in Oxfordshire, Buckinghamshire and Berkshire examples. ${ }^{40}$ Here a comparison of the geology and soils of the mōr-tüns and mersc-tüns showed them to be very similar, with settlements on better drained river terraces or glacial sands and gravels (with soils in the $500 \mathrm{~s}$ group) but adjacent to areas of clay or alluvium with soils mostly in the $700 \mathrm{~s}$, but also the $400 \mathrm{~s}$ and $800 \mathrm{~s}$, reflecting the ill-drained land. The results were consistent with the settlement being primarily concerned with utilising ground that was too ill-drained to plough without major drainage work. It could, therefore, best be used as pasture or hay meadow - or left as waste. If it is not possible to distinguish between the mersc-tüns and mōr-tüns on the basis of their soils and geology there may be some other way to distinguish between the two groups: perhaps one group was primarily concerned with hay production and the other with good quality grazing. Their distribution does show a difference in that the mōr-tüns extend further north into NTB and the Lake District (if post-DB examples are included) and further southwest into DEV. Both are most common in the Midlands and scarce in East Anglia and southeast England. An analysis of the distances of the mör-tüns and mersc-tüns from Roman roads and ancient trackways shown on the O.S. Map of Roman Britain shows a modest degree of correlation in the case of mör-tün, but when the navigable rivers, and the Gough and Ogilby routes are taken into account the correlation is good with medians of 1 and $11 / 2$ miles and inter-quartile ranges of $17 / 8$ and $11 / 4$ miles: rather more mersc-tüns than mōr-tüns being beside Gough, Ogilby and such routes (see Chapter 9, Synthesis, and dispersion graphs: figs 5.22 and 5.25).

\footnotetext{
${ }^{40}$ Helen Maynard, 'The Use of the Place-Name Elements Mōr and Mersc in the Avon Valley', Transactions of the Birmingham and Warwickshire Archaeological Society, 86 (1974), pp. 80-4
} 
There are, then, two terms, mōr-tün and mersc-tün, which are sufficiently widespread to be useful to travellers. They correlate well with old routeways and because of the large numbers of mōrs and merscs qualifying $t \bar{u} n$ may be suspected of being functional $t \bar{u} n$ s. Additionally they are places where the production of hay or good quality grass would be environmentally appropriate. So the question is what were the functions of the mōr-tūns and mersc-tūns and could it have been related to the needs of road users in the form of supplying fodder and/or payload, or were they only component parts of multiple estates as Gelling suggests in her consideration of the great estate at Blewbury BRK (now OXF)? This consisted of Blewbury, Aston Tirrold, Aston Upthorpe, North Moreton and South Moreton (all now parishes). She said:

'Some mōrtūn settlements may be component parts of multiple estates. North and South Moreton BRK were in the $10^{\text {th }}$ century part of a 100-hide estate centred on Blewbury, and it is easy to see them as the suppliers of hay for the whole unit ${ }^{41}$

Blewbury and the Astons lie on Lower Chalk. North and South Moreton are sited on rising ground overlooking an ill-drained expanse of alluvium, and so this would be a very suitable use of resources. Other mör-tüns may have originated in a similar way: small settlements called $m \bar{o} r-t \bar{u} n$ near Thame, Aylesbury and Oswestry come to mind. Even if the mör-tüns are hay-making settlements it does not explain how they got their names nor why there is such a close relationship to important routeways. In cases like Blewbury the hay would only need to be moved short distances within the estate, usually along a local track. Elsewhere, by chance, the hay could have been moved, still within the estate, along a short stretch of an important routeway: there is nothing to indicate that if a mōr-tīn is near an important road the hay is likely to be moved long distances on it. Indeed, as a bulky commodity, one would not wish to transport it far, but proximity to an important route would be a convenience for would-be purchasers who wanted hay for immediate consumption or a pay-load over a short distance say a day or two's journey. If the mersc-tüns fulfilled a similar purpose the same questions must be posed about them too.

It was Margaret Gelling, trying to account for the recurrent tün names of Shropshire, who made the suggestion that these names may have originated in the speech of Mercian administrators. She says:

'Shropshire has 10 Astons, 8 Westons, 7 Nortons and 8 Suttons, and there are 5 Uptons, 4 Middletons and 10 Newtons. Acton occurs 8 times, Eaton 6 and Eyton 5. There are 4 instances of Hatton, Mor(e)ton and Wootton. There are 5 Prestons. It is possible that such names were originally convenient labels used by Mercian administrators, who could have been in the habit of saying that a settlement was the éa-tün of a particular composite estate, or the preosta-tün of a minster church. Such appellations might eventually have come to be perceived as place-names and ousted earlier British names of these places'. ${ }^{42}$ (see pp.18-9)

In other areas OE place-names may have been ousted rather than British ones, and the administrators were not necessarily Mercian, but the idea of the names being imposed from above whether by 'administrators' or by the holder of the estate seems to be a possibility. It is also worth considering whether the mōr-tün and mersc-tün names might have been coined by the inhabitants of these settlements, by the people of the neighbouring settlements or by travellers - the three other alternatives suggested in chapter 1 . If the terms mōr-tün and mersc-tün were recognised countrywide as meaning 'hay meadow settlement' or 'grassproducing settlement' then it is possible that the inhabitants or their neighbours adopted one of those names for the settlement. It is equally possible that the holder of a large estate chose

\footnotetext{
${ }^{41}$ Gelling and Cole, Landscape, p. 59.

${ }^{42}$ PN. SHR, 1, p. xiv.
} 
to use one of them for the appropriate subsidiary settlement, or even as Gelling suggests they might have originated in the speech of (Mercian) administrators. They seem less likely to have originated in the speech of travellers because the correlation with important roads is not sufficiently close even when including the Gough, Ogilby and other such routes. This is no bar to the terms being important to travellers, for they, understanding the meanings, would know that good grass was produced in these places, and might be available for immediate consumption by their animals or to purchase as a payload in the form of hay. However, it is unwise to assume that mōr-tūn and mersc-tün had the same meaning. In the first place, synonyms are very rare in OE, but secondly, the distributions of the two terms are different: $m \bar{o} r-t \bar{u} n$ is much more widespread, extending north into Northumbria and the Lake District, and south-west into Devon, whereas mersc-tūn is rare outside the midlands. Mör-tün is more closely associated with Roman roads and mersc-tūn with non-Roman roads. Any traveller, as indeed everyone else, would know just what the terms implied and react accordingly.

The question as to why there should be such a good correlation with roads is harder to explain. Clearly a mōr-tūn or a mersc-tün is only likely to arise where the land is suitable for a hay crop (or good grazing) and this could be anywhere regardless of whether there was an important route nearby or not. It is less surprising that mōr-tūns and mersc-tūns should be by navigable rivers, because a river's floodplain could be a good hay/grazing meadow. It should be noted that not all mōr-tūns and mersc-tūns are by important routes: two mōr-tūns in DUR, one in CHE, one in SHR and two in WOR are at least four miles from a Roman road, old route or navigable river, as is a mersc-tün in WLT. In contrast, major names having the form 'element $+m \bar{o} r$ ' or 'element + mersc' are more variable in their distances from old routes or navigable rivers; median distances and inter-quartile ranges are larger - the distributions are more nearly random. Evidence, therefore, suggests that mōr-tüns and mersc-tūns were where hay (or good grazing) was produced, that they were not randomly distributed, but correlated with roads and navigable water. A traveller passing a mōr-tün or a mersc-tün was likely to have been aware of this. In summary, what has not been proved, but seems likely, is that these places acquired their names to illustrate their function, and that they had a surplus of hay (or good grazing) which in the first place supplied the estate to which they belonged and in the second place might have been offered for sale to nearby estates, to feed passing livestock or to take to a nearby urban centre for sale. As such the mōr-tüns and mersc-tüns were significant points on a journey for many road-users.

\section{ASSISTANCE TO TRAVELLERS IN DIFFICULTY}

a) DRAEG-TUN and DRAEG-COT

So far, the travellers have information on the nature of the road, the river-crossings, the availability of water, food, shelter, and fodder for animals. Their journeys might be straightforward and uneventful, but on the other hand there were many problems that could beset them; they might lose their way (but see chapter 8), or they might be set upon by robbers or wild animals. The route itself might cause difficulties: it might be steep (but see under weg), the river-crossings might be impassable owing to floods (but see under gelād), or the track might be deep in mud, poached by passing animals or rutted by cartwheels. The draeg-tüns and drag-cots, 'places where things are dragged', may be tüns and cots whose special function was to aid travellers where the condition of the route posed problems. This was suggested in Cole $1994,{ }^{43}$ but the starting-point for any discussion of the 37 places called draeg-tün and 16 called drag-cot must be Ekwall's article in Namn Och Bygd ${ }^{A 4}$ which is

\footnotetext{
${ }^{43}$ Cole, Traveller, pp. 7-18.

${ }^{44}$ Eilert Ekwall, 'The English place-names Drayton, Draycot, Drax etc', Namn Och Bygd, 20 (1932), pp. 46-70.
} 
summarised in Ekwall and Smith ${ }^{45}$ under draeg. Ekwall likens OE drag to OScand drag, which was used to mean 'a place where boats were dragged over a narrow piece of land separating two lakes or streams or through a channel too narrow for rowing', 'a place where boats can be put up', or 'a way along which timber or wood can be dragged'. He suggests that drag means 'place where any object is or could be dragged'. Because the word drog is never found in independent use but only in place-names, he comments that 'it is obvious that the only way of reaching a definite conclusion as regards our element is a careful examination of the situations of the places whose names contain it'; he does this listing a number of Draytons and Draycots where he believes portaging from one river to another may have occurred, e.g. East to West Drayton NTT; where portaging to cut out a river bend occurred, e.g. Drayton St Leonard OXF, and places where a steep ascent means that 'one has to pull strongly or horses have to make a strong effort', e.g. Drayton Beauchamp, Drayton Parslow, Dry Drayton, and Draughton NTP. However, boatmen are reluctant to portage if there is any alternative possible. It is slow, hard work to manhandle a cargo and perhaps a boat overland: only an obstacle such as a waterfall or rapids, or the need to change from one river-system to another will persuade people to do it. Portaging was probably more widely practised in the glaciated, mountainous countryside of Norway and Sweden, with its immature drainage system and fjorded coastline, than in England; a good example is the Dragseidvegen near Selje, Norway, a way linking Drage to Leikanger over a 600ft-high peninsula, thus avoiding a dangerous seaway around the steeply-cliffed West Cape; another is at Dragsvik - a landing-place on a spit jutting into Sognefjord which has otherwise precipitous sides. These are the kinds of situations which influenced Ekwall's thinking, but they do not pertain to an English landscape, so that interpreting the Draytons and Draycots as places where portaging took place should be a last resort. A second criticism is that many of Ekwall's examples of places where steep slopes needed an extra effort are not very steep at all; there are, for instance, innumerable tracks up much steeper hills than those at Drayton Parslow (c. 1 in 33) and Draughton NTP (c.1 in 42) which have no Draytons or Draycots by them. The reason why Ekwall's explanation has its limitations is because he had apparently failed to notice the large number of Draytons and Draycots on or very close to Roman roads or other important routeways, particularly where those roads crossed rivers, and he was unlikely to have observed the problems that could sometimes beset travellers when those roads were flooded. For instance, the river Thame, rising in the clayey lands of northern Buckinghamshire and north-east Oxfordshire, is very liable to flooding. At Drayton St Leonard OXF, the ford in the village can easily be waded in summer, but in flood time the approach-tracks are under water and the river is too deep and fast to be crossed readily. The Roman road, M 173a, from Dorchester to Fleet Marston running through Drayton St Leonard towards Stadhampton crossed the Thame at a ford at SU 601977, now the site of Haywards Bridge. There are duckboards for pedestrians because the road itself is often under water and impassable to traffic. Six miles away this same Roman road re-crossed the Thame at a ford (now lost) near Shabbington. The present road runs through Draycot near Waterstock, crosses the Thame at Ickford Bridge (some $3 / 4$ mile downstream from the Roman ford), and proceeds to Ickford. In winter there can be extensive floods on both sides of the river, when it is deep and fast-flowing. The present road is built on a causeway so that the twin bridges over the channels are usually passable. Even on this country lane there was already a bridge by 1237 , when it needed repair: ${ }^{46}$ an indication of the problems of the crossing. Draycot lies safely on rising ground $3 / 8$ mile from Ickford Bridge and $3 / 4$ mile from the Roman ford, in a position whence it could aid travellers. The same sort of conditions prevail at other Draytons

\footnotetext{
${ }^{45}$ DEPN, s.n. drag: Smith, Elements, 1, p. 134-6.

${ }^{46}$ E. Jervoise, Ancient Bridges of Mid and Eastern England (London, 1932), p. 151
} 
and Draycots. (See vol. 2, pp. 194-204 for details). For instance, Fenny Drayton LEI is near Mancetter where Watling Street crosses the Anker, and Drayton SSX is near where Stane Street crosses the river Lavant. This pattern is repeated often, with the drag settlement on rising ground away from the flood danger. It therefore seems likely that these settlements performed some useful function in helping travellers negotiate difficult crossings (see list, fig. 5.26 and map, fig. 5.27).

A close examination of all the Draytons and Draycots shows that not all of them are associated with routes crossing substantial rivers. Some cross quite tiny streams, but these are often in clayey country where, in winter, the road-surface, if not paved, could become deeply rutted by cart wheels or heavily poached by hooves, making progress slow and laborious if not impossible. For example, the Roman road from Cambridge to Godmanchester skirts the edge of the Fens running over clays, undulating gently to cross small streams draining to Fenland. Dry Drayton CAM, is atop a low hill from which the Roman road, dipping to cross the stream near Bar Hill, can be seen, and before recent development there was a track from Drayton giving access. About 4 miles to the north-west the road crosses two more streams, one of which, flowing reed-lined alongside the High Street, gives Fen Drayton its prefix: there is ready access to the Roman road. Both these Draytons are positioned so as to be able to give help to travellers along the muddy fen-edge and across the streams when they are in flood.

Ekwall also suggested that drag-tūns and drag-cots were associated with steep hills. The prime example is Drayton Beauchamp BUC, beside Akeman Street where there is a long, slow haul up Tring Hill, gradient about 1 in 13, even steeper before the present road was let into a cutting. There was once access to the foot of the hill by a track and there is still a hollow way running back to Drayton Beauchamp from the top of the hill. There is no question of a river crossing or wet ground here.

These examples all involve traffic on Roman roads, but a substantial number of Draytons and Draycots are by other old routes. Drayton near Langport in Somerset lies $1 / 2$ mile off Old Way, a route from Somerton to Curry Rivel with branches to Taunton and Hambridge; it crosses the river Parrett and its marshland at its narrowest point at Langport. Drayton is so placed that help could be offered both at the crossings of the Parrett at Langport, and of the Isle to Hambridge or to Muchelney or Midelney. Drayton in Bighton HMP is near the source of the Alre; an old route passes through Abbotstone, Old Alresford, Bighton and on to Alton. In this chalk country springs flow very freely after a wet winter, making the area around Old Alresford very marshy. The track near Drayton contained a running stream in May 1994: deep mud had collected in hollows on the firm chalk base and was impassable on foot. Draycot Fitzpayne, near Oare in Wiltshire, is at the foot of a steep chalk escarpment on the north side of the Vale of Pewsey down which several tracks descend, such as the Great Ridgeway $13 / 4$ miles to the west, a route from Manningford Bruce to Marlborough 11/4 miles to the east, as well as a route through Draycot itself; it would thus be in a position to help travellers on several routes climbing or descending the scarp-slope.

The discussion of individual draeg-tüns and drceg-cots in vol. 2 shows that almost every one is associated with a routeway; nearly half of these are Roman roads and most of the rest are other old routes. The old routes in question are rarely those on the O.S. Map of Roman Britain (which, being ridgeways, rarely cross rivers): they are those occurring in charterboundaries identified by Grundy, mostly in Hampshire and Wiltshire, some identified by Cochrane $^{47}$ leading from Wessex to London, and - for an important minority - those appearing in Ogilby's Road Book of 1675; as three of the draeg names on the latter are recorded pre-Conquest, two more in 1086 and the others in 1208, 1255-6, 1285 and 1387 it

${ }^{47}$ C. Cochrane, The Lost Roads of Wessex (London, 1972). 
suggests that these nine routes Ogilby was describing were already over 300 years and some over 600 or 700 years old. This is reinforced by the fact that the Gough Map of c. 1360 indicates that four of these routes of Ogilby's were in existence in c. 1360, involving West Drayton and Drayton Green MDX, Drayton near Daventry NTP, and West Drayton NTT (see end-paper map).

The information about flooding is derived partly from personal observation, but mostly from the Environment Agency web site. ${ }^{48}$ This shows areas liable to experience a lin 100 years flood (a flood so extensive that it is only likely to occur once in a hundred years). This is not really appropriate information because, since Anglo-Saxon times, the flood-prone areas have been modified by engineering works such as railway embankments, road building and flood defences, while hydrological conditions may have changed too. Moreover, the area liable to flooding once in 100 years is much more extensive than would be experienced in most years. A once in a 100 year flood is too rare an event for the Anglo-Saxons to have identified the places where it happened and to establish a network of settlements to deal with the problem. Only if floods happened in most years would they have become widely known and measures to cope with them could have been established. Therefore the areas shown on the web-site would be narrower for the more frequent floods

The nature of the assistance to travellers at a drag-tūn or a draeg-cot is not known, but some suggestions may be made. The problems faced by someone wishing to cross a flooded river are the increased depth of the water and speed of current in the channel, and the shallow but wide expanse of water on the floodplain. Fording would not be possible, extra draught animals attached to a waggon would not be practicable in the deep water, and so some sort of raft (a shallow draught is essential) to act as a ferry would seem to be the answer.

A great problem faced by travellers along very muddy tracks was that wheeled vehicles quickly became bogged down in deep ruts; pack-animals would have found it a little less difficult. Extra draught animals might not be an answer to the problem, however, a sled, which distributes the weight of the load more widely, could be used, so long as the draught animals could negotiate the muddy track.

On a steep hill there were two different problems. In the ascent, more pulling-power would need to be applied to the waggon; spare oxen or horses kept at the foot of the hill could provide this. Within the last 100 years spare horses were kept at the foot of Headington Hill near Oxford, and when the road from Oxford to London went over Shotover Hill spare horses were kept there too (sceot 'steep'). The descent of a steep hill with waggons could be dangerous. Some method of restraining the load with a winch or extra braking would be needed, or alternatively the load could be taken down on a sled which had a much more effective braking system and was much safer (see windlesora below).

It would appear that the draeg-tuns and draeg-cots grew up where extra traction of some kind was needed by travellers on important route-ways. They are examples of functional tūns and the less common functional cots. It has not been possible to distinguish between them on the grounds of differences in the routes or differences in the problems they are there to resolve. They are good indicators of major routes in use, and particularly valuable in indicating the non-Roman routes. As well over half of them are evidenced by 1086 they are helpful in identifying the early medieval route-way network.

The other examples of droeg in place-names, listed in vol.2, pp. 203-4, show that the term was used in the same sense, but not generally along important routes. Three of them are noteworthy because they appear to have been given or influenced by Scandinavian speakers. Drigg CMB, and Dundraw CMB, places where boats were drawn up on a beach, have their parallels in Dragsvik, Norway. Drax YOW seems to be the only example which could be

${ }^{48}$ www.environment-agency.gov.uk 
interpreted as a portage; in these the meaning of the term draeg is closer to that employed in Norway than to that employed by the Anglo-Saxons.

b) WINDLESÖRA

The OE term windlesōra, modern Windsor, Winsor, might also represent a place with a function useful for travellers. By $1940 \mathrm{Ekwall}^{49}$ had suggested that the first element referred to a windlass, and taking the now discredited 'river-bank' meaning of ora, suggested that the whole meant 'landing-place with a windlass'. Smith ${ }^{50}$ concurred, but Gelling ${ }^{51}$ noted that the watercourses at Winsor HMP, and Broadwindsor DOR, were too small to have ever been navigable, while acknowledging that a windlass might be useful to those ascending a steep slope. The question, then, is whether or not these windlesorras were on major route-ways and whether they assisted the travellers on them.

Assembling a corpus of reliable examples is not easy because some may be transferred names from the well-known Windsor (Castle) in BRK, particularly those evidenced comparatively late and those referring to only minor features, such as Windsor Hill, Knipton, and Windsor Hill, Princes Risborough BUC.

Fig. 5.28 lists ten examples and some relevant data. Windsor $\mathrm{CMB}$ is not evidenced until 1570 , and is far north of any other example of ora; Windesore Mill (lost) DBY is also rather far north; however if windlesōra was a technical term rather than a name made up of two separate elements this might not matter. Even if these two examples are eliminated, the remainder vary in their situations. Only two or possibly three are by navigable water where boats might be hauled up by windlass; five are not. Four are by steep hills, but two of these are not evidenced until the sixteenth century. At Broadwindsor DOR the stream is not navigable, and the ascent from the stream to the village is only moderately steep; vast numbers of settlements are in such situations and yet are not called Windlesöra. Winsor HMP has only a slight hill nearby; it is too far from Southampton Water for that watercourse to be relevant. Three are close enough to old routes (the Great Ridgeway and two Roman roads) to be of use to travellers - if that is indeed their function. Two others, both first evidenced in the sixteenth century, are on the edges of the plateau north of Honiton discussed under weg, where a windlass would be useful in aiding the last steep ascent to (or descent from) routes along the plateau; indeed, one is close to a place called Greenway.

This is not a large corpus, nor is it very uniform. It is not always clear what the windlass is being used for. It is therefore of little use in helping to determine what the major routes-in-use were in early medieval times.

\section{PAY-LOAD}

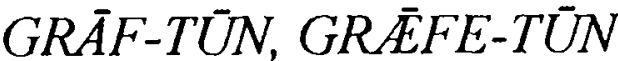

The term OE gräfe, gräf, gräfa, gräfe, a 'grove', is discussed in Gelling $1984^{52}$ and Gelling and Cole $2000{ }^{53}$ the suggested meaning is 'managed woodland', probably coppice. It is not always easy to distinguish from OE grafa, graef, 'a trench', but the thirteen examples of Grafton seem to derive from the 'grove' word. Gelling hinted that a Grafton might have some particular role in the economy of an estate. An examination of their distribution bears this out, so that the Graftons should be considered as further examples of functional tüns (for details see fig. 5.29 and map: fig. 5.30). Six are within easy reach of a salt-way coming from Droitwich. Of particular interest is Grafton Manor WOR, just south of Bromsgrove. The name Bromsgrove suggests that there was coppice of economic significance locally; in fact

\footnotetext{
${ }^{49}$ DEPN (second edition), s.n. Windsor.

${ }^{50}$ Elements, 2, p. 268.

${ }^{51}$ Gelling, Place-Names, p. 182.

${ }^{52}$ Gelling, Place-Names, pp. 192-4.

${ }^{53}$ Gelling and Cole, Landscape, pp. 226-8
} 
Bromsgrove was a large estate which supplied Droitwich with 300 cart loads of wood yearly according to DB. Grafton Manor was well-placed for its people to be closely involved with the coppicing of the grove and the transport of the wood along M 180. The other Graftons associated with salt-ways are Grafton in Beckford GLO, about 16 miles from Droitwich; Temple Grafton WAR, some 15 miles east of Droitwich close to the salt-way-cum-Roman road M 56b; Grafton in Bockleton HRE, on a proposed salt way to Leominster and some 20 miles from Droitwich; Grafton Flyford, about 6 miles from Droitwich; and Grafton OXF, beside the Thames midway between Bampton and Lechlade, both of which were at the ends of salt routes (or at least at the probable end of overland journeys, since the salt could have gone on by river; Eaton Hastings nearby may have been responsible for keeping it navigable here). Bampton had salt rights in Droitwich. It might seem a long way $(15,16,20$ miles) to move coppice poles to Droitwich, but if the pack-trains or waggons which had carried the salt outward bound would otherwise return unladen it may have been economically worthwhile. If so, the Cheshire Grafton, which is close to the saltway from Nantwich to Wales, would likewise have been supplying coppice poles to a salt-making centre. Hooke notes several places mentioned in charters which were required to supply Droitwich with wood: Northwich with Tibberton 100 cartloads, Martin Hussingtree also 100 cartloads - distances of about 4-6 miles. More distant places such as Leominster and Much Marcle paid cash. ${ }^{54} \mathrm{John}_{\text {Blair }}{ }^{55}$ has also commented on the economic feasibility of waggons/pack-trains returning to Droitwich from places with salt rights with loads of coppice wood: 'The actual carriage of firewood over such distances in the eighth and ninth centuries may be less implausible than it sounds: the supply was guaranteed and free, and the salt waggons presumably had to return to Droitwich'.

Grafton SHR is on the river Perry on the opposite bank to Yeaton, an $\bar{e} a-t \bar{u} n$, which was probably responsible for keeping the Perry navigable for the 2 miles to its confluence with the Severn (cf. Grafton OXF).

The other five Graftons are by well-wooded areas which later became the royal forests of Savernake WLT, Rockingham NTP, Whittlewood NTP, Knaresborough YOW, and Haywood HRE. Four of the five are within 1 mile of a Roman road or other old route, so that the woodland products would have ready access to the routeway network, and so could be moved to wherever they were needed. Two Graftons are adjacent to mere-tūns (YOW, WLT) this may be no more than coincidence, or maybe the mere-tüns were stopping places while carts or pack-trains were loaded with timber.

The Graftons, therefore, needed to be close to the route-way network to function efficiently, and so can be helpful as supporting evidence of a route-way in use.

\footnotetext{
${ }^{54}$ Della Hooke, 'The Droitwich Salt Industry' in Anglo-Saxon Studies in Archaeology and History 2, ed. David Brown, James Campbell, Sonia Chadwick Hawkes (BAR British Series, 92, Oxford, 1981), pp. 140-2.

${ }^{55}$ Blair, Oxfordshire, p. 86. See also J.R. Maddicot, 'London and Droitwich c. 650-750: trade, industry and the rise of Mercia', Anglo-Saxon England, 34 (2005), pp. 7-58.
} 


\section{WATER TRANSPORT ${ }^{1}$}

Not all journeys were made by land. There are navigable rivers such as the Thames, Severn and Trent leading into the heart of lowland England. There is also a long coastline bordering the North Sea, English Channel and, to a lesser extent, the Irish Sea, whence came trade and travellers. This has engendered a number of place-names relating to water transport such as port, hỳth, stceth, stothr, läd and e $a-t \bar{u} n$.

Water transport has certain advantages over land transport, particularly for the movement of goods which are heavy, bulky or need moving in large quantities; for instance, stone from the Taynton quarries was floated down the Thames to Oxford and beyond, ${ }^{2}$ while it is known that a channel was cut specifically to enable stone to be brought by boat to build the abbey at Sawtry HNT, because of a dispute between Ramsey and Sawtry Abbeys concerning it in $1192 .^{3}$ In addition, pottery is more safely moved by water than overland in a jolting cart. A sea crossing was, of course, the only way of reaching the Continent or Ireland.

Water transport also had its disadvantages: fog, storms, rip tides, and adverse winds and currents caused accidents, delays and loss of position at sea. Rivers did not necessarily lead to the desired destination, and even if they did their meandering courses might make the journey twice as long as the overland route; for example, Oxford to London by road is 57 miles but by river it is 114 miles. In times of flood or drought the river might not be usable at all. There were obstructions in some rivers such as rapids and, particularly in the later middle ages, man-made obstacles such as weirs and fish traps.

It is rare for a complete journey to be made by water; at one or both ends the water route needs to link up with an overland route at a trans-shipment point, ideally to produce an integrated transport system. Therefore, when considering the sites of ports and landing places it is helpful to identify any road links. An oft-quoted route is that from Cambridge to York undertaken by some young scholars in $1319 .^{4}$

There have been several attempts to identify the rivers used for transport in medieval England, notably in the articles in the Journal of Historical Geography by Edwards and Hindle, Langdon, and Jones. ${ }^{5}$ These authors derived their evidence from references in postConquest documents; Edwards and Hindle used Calendars of State rolls (some one hundred and eight volumes) between 1219 and 1441, and identified large numbers of rivers in use, including many short stretches near the coast, as well as along major rivers and their tributaries. Langdon used purveyance accounts between 1290 and 1350 and identified far fewer waterways being used. They were in agreement that the Parrett, Severn, Thames, Medway, Bure, Waveney, Yare, Fenland rivers, Witham, Trent, Yorkshire Ouse and Hull

\footnotetext{
${ }^{1}$ The substance of this chapter appears as chapter 3 in Waterways and Canal-Building in Medieval England, ed. John Blair (Oxford, 2007).

${ }^{2}$ W.J. Arkell, Oxford Stone (London, 1947), p. 61.

${ }^{3}$ H.C. Darby, Medieval Fenland (Newton Abbot, 1974), p. 101.

${ }^{4}$ Stenton, Road System, p.20. The party that travelled wholly by road took five days, but it took the scholars eight days of travelling: Cambridge to Spalding by water; Spalding to Boston overland; BostonLincoln-Torksey-York by water.

5 J. Edwards and B. Hindle, 'The Transportation System of Medieval England and Wales', Journal of Historical Geography, 17 (1991), pp. 123-34; 'Comment: Inland Water Transportation in Medieval England', J.H.G., 19 (1) (1993), pp. 12-4; John Langdon, 'Inland Water Transport in Medieval England' J.H.G., 19 (1) (1993), pp.1-11; Evan Jones, 'River Navigation in Medieval England, J.H.G., 26 (2000), pp. $60-82$.
} 
were in use, but disagreed how far upstream this use extended. Jones attempted to bridge the gap by re-examining some of Edwards' evidence, and eliminating the least secure. He also noted that Edwards' time period was 222 years - much longer than Langdon's 60 years, and that during these two centuries many changes could have occurred; river channels themselves evolve as meander loops tighten and eventually get cut off, gravel banks wax and wane in response to flooding episodes, and estuaries silt up. Man has embanked, straightened and dredged channels making the rivers narrower, deeper and faster flowing. He has obstructed the flow with fish traps, mill weirs and in recent centuries has improved navigation with pound locks. These factors must be borne in mind when attempting to assess which rivers were in use at any particular time.

Langdon, again using purveyance accounts, tries to identify the sizes of vessels in use, and the amount of load that could be carried; he concluded that on the lower Thames a barge-like vessel some 30 yards long and having a draught of $4 \frac{1}{2}$ feet could carry some 35 tons, but that on smaller rivers such as the Parrett, vessels are likely to have been 5 yards long and been able to carry 2 tons. ${ }^{6}$ The lower reaches of sizable rivers, so long as they are unobstructed, are useful for water transport, but the problem is in assessing how far upstream that river can be used. Assuming for the moment that there are no man-made obstacles, the limiting factors for a load-carrying vessel concern the nature of the channel: whether it was rocky and full of white-water or smooth-floored and calm watered; what the depth of the water was; what the width, and the wave-length of the meanders were. In fact there is a correlation between the last two: the narrower the channel the smaller and more numerous the meanders. ${ }^{7}$ If the meanders are too tight it would be impossible to manoeuvre a long boat through them; it would also be very time-consuming and lengthen the journey considerably, and there would be a point at which it would not be worthwhile. Just where this point might be would depend not only on the state of the channel, but also on whether there was a suitable alternative route overland; what was the nature of the load - could it be broken up into smaller portions that could be taken by packhorse? How urgently was the load needed at its destination? Was the river navigable at all seasons or was it too low in summer or subject to floods in winter? The length of the journey also needed consideration - would it be better to use a flotilla of small boats to carry a load from the headwaters of a river to its mouth - for instance from Lechlade to London along the Thames, or was it better to amalgamate the small boat-loads and stow them on one large vessel at some point, say, Henley? How important was it for the waterways to tie into the road network? Before a normally navigable stretch was used the boatmen would want to know if it was actually open; had it been kept clear of invading vegetation, had a gale blown a (willow) tree into the water, or had heavy rain washed silt and gravel off the fields, blocking or shallowing the channel?

Besides these natural constraints, which would apply at all periods, there were human factors to consider: had man done anything to obstruct the flow? The constant complaints of boatmen on the Thames in the middle ages were that fish weirs and traps, mill weirs and flash locks obstructed their free passage. This seems to have been a particular problem in the later medieval period. The mills recorded in Domesday Book tended to be on smaller streams such as the tributaries of the Thames (like the Evenlode, Windrush and Sor Brook), which would not have been important for water transport, rather than on the major

\footnotetext{
${ }^{6}$ Thirty-five tons of grain has a volume of $75 \mathrm{cu} . y d s$, two tons a volume of $4.28 \mathrm{cu} . \mathrm{yds}$, while an Oxbridge punt carrying six adults has a load of half a ton. John Langdon, 'The Efficiency of Inland Water Transport in Medieval England' in Blair, Waterways, p. 123.

${ }^{7}$ Andrew Goudie, The Nature of the Environment (Oxford, 1984), p. 288; Ed. Rhodes, 'Identifying Human Modification of River Channels' in Blair, Waterways, pp. 133-52.
} 
waterways. ${ }^{8}$ In the earlier centuries of the Anglo-Saxon period, mills and fisheries would have presented far fewer problems to the boatmen than they did in the centuries after the Norman Conquest, and so river traffic was less constrained. By the end of the early medieval period there is evidence of steps being taken to improve navigation by the construction of canals to cut off meanders or bypass difficult stretches (e.g. at Abingdon) or to link river systems (e.g. in the Fens). ${ }^{9}$

Boats not only plied the rivers, but also would have been used on coastal voyages, particularly along the eastern and southern coasts where the countryside was more populous, and the sea conditions less dangerous. There would have been cross-channel traffic to the Low Countries and France, and to Ireland.

Any study of ports and landing places is complicated by the changes in topography that have occurred, and are still occurring, along the coastline, caused by changes in sea level. The changes in south-eastern Britain since the Ice Age have been a rapid eustatic rise in sea level as the ice melted, flooding coastal plains and the lower reaches of river valleys to form an irregular coastline of rias and estuaries; this was reinforced by a slow, stillcontinuing isostatic depression of the South-East. Acting in opposition to these are the erosional and depositional forces wearing back the headlands, silting up the estuaries and generally smoothing the coastline. The speed of silting depends on the supply of material and the size of the inlet concerned; its variability accounts for the smooth coasts of Norfolk and Suffolk, which have a good supply of material, in contrast to the smaller supply to the surviving inlets of the Essex coast. Similarly, the inlets east of Chichester have silted up while those to the west around Portsmouth and Poole have not. Elsewhere erosion has claimed coastal land and settlements; the many sea-swallowed settlements of Holderness, the East Anglian town of Dunwich, and parts of the former island of Selsey are examples. Because of these changes through the centuries some of the erstwhile ports function no longer: they have been washed away or find themselves well inland, while other places have developed as their situations became advantageous. In recent centuries the growing size of ships has rendered some ports like London useless for large vessels. Ports are also dependent on continuing trade to keep them viable.

Any port is likely to experience slow changes in its configuration over time, including during the millennium encompassing the Roman and Anglo-Saxon periods. Fortunately various authors have been able to deduce what these changes were at a number of the ports and $h \bar{y}$ ths under consideration here (they are acknowledged in the appendix to chapter 6 ). ${ }^{10}$ In order to understand why certain havens and landing-places were named port or hyth it is important to know what the surroundings were like some 1,500 years ago. This is much easier to ascertain where there has been deposition, than where there is/has been erosion destroying the old coastline; for many, such changes are described in the appendix.

Having discussed the pros and cons of water transport (above), and the individual places (in the appendix), some overall view of the place-names indicating water transport is now possible, starting with terms for havens and landing-places.

\section{PORT}

Care must be taken to distinguish between the three senses of 'port'. The first, port in Smith," is a borrowing from Latin portus, a 'harbour'; the second, port ${ }^{2}$, ultimately derives from Latin portus and was used in OE to mean 'town, market town, market' such as in

\footnotetext{
${ }^{8}$ H.C. Darby, The Domesday Geography of South-East England (Cambridge, 1962), p. 226.

${ }^{9}$ See for instance chapters 6 and 7 in Blair, Waterways.

${ }^{10}$ Outrageous Waves by B.E.Cracknell describes the changes to the British coastline from Roman times to the present day, and incorporates the work of these authors.

${ }^{11}$ Elements, 2, pp. 70-1.
} 
Bridport DOR and Langport (various counties). It was also used in the names of newly established settlements or those granted charters: Milbourne Port is one example and so could some of the Newports be. Port ${ }^{3}$ from OFr porte 'a gate' is found occasionally. It is the first sense that is relevant to early medieval travellers as it occurs in the names of several southern havens. The probable examples from east to west are: Portslade SSX, Portsmouth HMP, Portland DOR, Portlemouth DEV, Porlock SOM and Portishead SOM. ${ }^{12}$ (see figs 6.1 and 6.2).

Portsmouth Harbour was known as Portus Adurni in the Roman period, and would have been known to Saxon pirates frequenting the English Channel. It could well have been known far and wide as 'Port', a large sheltered haven for shipping. The landmarks nearby were named from it: Portsdown, Portsea, Portsmouth and Portchester; it did not suffer from silting to the same extent as some other inlets. Other similar sheets of sheltered water along the coast would be known as 'ports': Portslade - the difficult crossing over the sheltered estuary of the Adur before it silted up; Portland - the Isle of Portland sheltering Portland Roads from the south-westerly winds; Portlemouth - 'the mouth of the harbour stream', the harbour being the Kingsbridge estuary; Porlock - the enclosure by what used to be a sheltered inlet along a steep and rocky coast, and Portishead - the headland protecting an erstwhile bay along Severn-side (for details see vol.2, pp. 204-6).

The features that the six examples had in common were the wide expanse of sheltered, coastal water and the links into the road system: four by Roman roads and two (Porlock and Portlemouth) by other old routes. Judging by the references in the Anglo-Saxon Chronicle to Portsmouth, Portland, Porlock and Avonmouth near Portishead they were well known to seafarers and suffered many raids. It seems likely that the Latin term portus was adopted by Saxon pirates before the end of the Roman occupation, and therefore that these havens were known and used throughout the Anglo-Saxon period, and on into the postConquest period, until silting-up forced changes in the siting of landing places near Portslade, Porlock and Portishead. These are valuable indicators of routes in use in AngloSaxon times.

\section{$H \bar{Y} T H$}

$H \bar{y} t h$ is defined as 'a port, landing place on a river bank', 'landing place on a river, inland port' ${ }^{14}$ Most hyths fall into these categories, but a few are better described as coastal ports rather than riverside ones, and some are marshland sites. Their distribution is shown on the map: fig. 6.2 and they are listed in fig. 6.7.

Like the ports, the situations of some hyths have changed crucially over the centuries; New Hythe YER on the Holderness coast was washed away along with numerous other settlements, while Hive YER is now land-locked (see fig. 6.8 and vol.2, pp. 206-13 for details).

Few coastal hithes have remained unchanged. Hyton CMB, Heath Barn SSX, Old Heath ESX, and West Hythe KNT have all silted up; in the case of the last two they have been replaced by newer hithes both called Hythe.

The locations of the riverside hithes have changed much less. There is still a fine series on the tidal Thames near London. The sites of all but two were carefully chosen to be on one of the discontinuous patches of gravel terrace by the river where the ground is comparatively firm and well-drained, but Greenhithe is on chalk (perhaps the ground gets churned up less and the grass remains greener on this well-drained spot), and Rotherhithe

\footnotetext{
${ }^{12}$ Gelling, Signposts, chap. 3, especially pp, 78-9.

${ }^{13}$ Elements, 1, p. 278.

${ }^{14}$ Gelling and Cole, Landscape, p. 83.
} 
('cattle landing place') is on alluvium, where the soft ground must often have become poached and muddied by the feet of the many cattle passing through.

Most of the marshland hithes are in the Fens; here there are few gravel patches, but still the sites avoid the alluvium as far as possible, and are concentrated on the islands of clay rising above the marshes (see map: fig. 6.9).

The distribution map (fig. 6.2) shows that the hithes occur sparingly all round the coast, but are concentrated in the south and east. The Thames is well-served; the lower Trent has a few hithes, and a few smaller rivers each have a single hithe. There are none on the Severn, nor on the rivers north of the Humber. They are numerous in the Fens. This is easier to understand if the hithes are considered in two groups: the DB and pre-DB examples, and the post-DB examples. Fig. 6.10 shows these categorised by these two time periods and three types of location: coastal, riverine and marshland. For each the geology and the distance from a Roman road, 'ancient track' or 'old route' (such as a Gough route) is noted. In the cases of New Hythe and Riverhead KNT the hithes are near the Pilgrim's Way as the crow flies but across a substantial river, and therefore not very accessible to the road network.

There is a marked difference in the characteristics of each group. Of the 20 pre-DB and DB hithes, 13 are wholly or partly on gravel terraces, five on other firm ground, only one on clay; two are partly on alluvium; only Hidden BRK, whose exact site is unknown, may be wholly on alluvium. Twelve are sufficiently near the road system to be easily accessible from it, and could therefore be said to be integrated with it. This is especially true of the London hithes, and of Hythe and Glanty SUR, close to the point where M 4 crosses the Thames at Staines, and of Bolney OXF where two or three routes converge (a minor Roman road, Knightsbridge Lane and a lesser road from Rotherfield). Knaith NTT, by the Trent, is well placed for the Foss Dyke and M 28. Two, perhaps three, of the marshland hithes are within easy reach of the road network, but Lakenheath SFK and Hive YER are not. This distribution suggests that the hithes were sited where little needed to be done to improve the landing place, boats could be drawn up and goods and/or people loaded or unloaded without being impeded by mud and becoming horribly dirty. It suggests that most of the river traffic was on the Thames, and that this was an important highway for goods (it was too slow for most people) downstream to London; lighter loads could be taken back upstream especially in smaller vessels which were easier to row or tow than the larger, heavier ones. The many hithes near London would be well placed to handle cross-channel shipping - goods going to and from its important trading centres such as Lundenwic or Aldwych. Likewise, the east and south coast ports might also participate in the crosschannel trade. Hythe KNT was close to a road link (M 12 and M131), but Creeksea and Pudsey appear to have acted as gateways to smaller, more cut-off parts of Essex - the Dengie peninsula and south-east Essex were their hinterlands; they were not connected to the major routeway network.

The siting of the post-DB hithes was different in respect of geology, location and access to the road network. The sites of seven of these 32 hithes were wholly on alluvium, six wholly on clay, two on part-clay, part-alluvium; only four were wholly on gravel or terrace deposits, and three on other rock types. This large proportion of post-DB hithes on soft clays or alluvium contrasts with the high proportion of pre-DB and DB hithes on gravel (largely because of the Fenland examples). The distribution of these post-DB hithes indicates that traffic was using higher reaches of the Thames: instead of the highest upstream hithe being near Henley, it was well above Oxford. Hithes were to be found on smaller rivers such as the Medway, Darent, Adur and Axe. A cluster appeared on the Trent: West Stockwith NTT, East Stockwith and Walkerith LIN, were clearly associated with the water-route through the man-made Bykers Dyke, which ultimately linked Boston via 
Lincoln to York, avoiding the dangerous waters of the Humber estuary. Stockwith and Walkerith do not link in with the road system; they have ill-favoured sites being on alluvium and on the Trent's flood plain (hence perhaps the need for stocks or piling suggested in the name). They arose because they were at an important meeting point of waterways, and thus a good trading point (see map: fig. 6.11).

The other notable development was in the marshlands especially the Fens (see map: fig 6.9 ). Numerous hithes appeared serving the islands in the Fens. Mostly they had no choice but to be on clay or alluvium; however, they mostly managed to avoid the latter. The courses of the old fenland rivers and man-made waterways are not perfectly known, and very difficult to date, but it seems likely that these hithes grew up close to existing waterways to which they could readily be linked by a short channel. It would not be too difficult to dig out clay and alluvium, but the water and tough vegetation would be challenging. Other hithes developed along the fen edge, such as Methwold Hythe, Clayhithe and Earith, but they were rarely within easy reach of the road system. The considerable changes in the fenland landscape were due to the activities of the monasteries in reclaiming land by drainage, by cutting canals to move goods around their estates, and to bring in the stone needed to build their abbeys. There was more emphasis on local traffic than on long-distance or overseas traffic, and so the need to link into the roadway network was much less - it did not matter too much if the hithes were distant from the roads. Something similar happened in the Somerset Levels, but this marshland had two long ridges of upland, the Polden Hills and the Wedmore ridge, penetrating deeply into it, and so there was better land access to the marshes and to the settlements within it, and less need for hithes to serve the isolated 'islands' in the marsh (see map: fig. 6.12). There are only two hyths, Hythe and Bleadney (and one stoth), both close to presumed routes; the one along the foot of the Mendips for which there is good place-name evidence; the other by Wedmore with only a path to suggest its use.

The post-DB hithes are found much further west along the coast, down to south Devon, and round Land's End to Hyde near Bideford; they reappear again in Lancashire and Cumberland, indicating traffic across the Irish Sea.

The pre-DB and DB hyths therefore contrast with the post-DB hyths in terms of the geology of their sites, their location in England and their access to the road network. The conditions bringing about these contrasts did not appear overnight with the Norman Conquest and the compilation of Domesday Book, but evolved over many years, particularly with the growing influence of the monasteries. It is possible to get a glimpse of the expanding numbers of hithes through the place-names: Maidenhead is recorded as Elintone in DB, and by 1202 as Maidenhead; the change might be linked to the growth of the Gough route which crossed the Thames there, en route from London to Bath and Bristol. Further up the Thames, Bablock (1227) had Hythe added by 1581-2; in the Fens, Clayhithe was simply Cleie in 975 (twelfth century), but Clayhithe in 1268. It is the earliermentioned group which is most helpful in identifying which rivers were in use in early medieval England - precisely the ones which tie in best with the road network.

\section{ST AETH OE, STQTH ON ${ }^{15}$}

'Staithe' as a term for a landing place presents a number of difficulties. It could derive from OE stceth; this usually meant 'river bank' in charter boundary references, but later came to mean 'landing place'. In much later centuries it was used of places where coal was unloaded - there are three names with this origin around the Great Estuary in Norfolk; it is important to have early spellings. 'Staithe' could also derive from ON stoth, a 'landing

\footnotetext{
${ }^{15}$ These are listed in fig. 6.1, mapped in fig. 6.2 and discussed in vol. 2, pp. 213-4
} 
place'; it certainly appears in Burton Stather on the Trent which is evidenced in 1201 Nearby Flixborough appears in DB, but there are no early spellings available for Flixborough Stather, which is particularly unfortunate as Flixborough is a 'productive site' - one where finds of coins and metal work objects suggest that it was a busy trading place in Anglo-Saxon times, with many goods using the Trent to gain access. ${ }^{16}$ 'Staithe' could also derive from ON stathr, 'a place, a site'. It is often difficult to tell from which of the three terms a particular place-name is derived; where the language of origin of the first element is known it is assumed that the second, 'staithe', element is more likely than not to derive from the same language. This can present difficulties; in the case of Brimstage CHE (OE personal name Bruna + ?OE stceth), the situation of the settlement, over two miles from navigable water, means that it is unlikely to mean 'landing place' unless the settlement has shifted considerably. The same is true of Bickerstaffe LNC. Possibly they derive from ON stathr.

There are seven place-names which are certainly (or very nearly so) from the OE or ON term for a 'staithe': Statham CHE, Stathe SOM, Stafford STF, Staithes YON (all OE), Burton Stather LIN (ON), and Toxteth and Hubbersty LNC (probably ON). Only two are recorded as early as DB: Toxteth and Stafford; neither is served by a Roman road or any other known important old route (only Hubbersty is close to a Roman road). The other five are not evidenced until the thirteenth century.

There are four possible examples of 'staithe': Croxteth and Todderstaffe LNC, Birstwith YOW and Flixborough Stather LIN. At Croxteth the waterway is very small - one cannot say if it was big enough for a vessel by looking at the map. Todderstaffe is only an example if there was a dyke through the marshes by the time it was named, it is one of the few near a Roman road - half a mile. Birstwith is on the Nidd which is not regarded as a usefully navigable river, but it is only one and a half miles from where $M 270 \mathrm{~b}$ crosses it - a good site for a landing place if only the river was more readily navigable. Flixborough Stather lacks early spellings.

There are three places which are unlikely to be 'staithes' because there is no nearby waterway: Brimstage, Bickerstaffe and probably Birstaff Bryning, which is now one and a half miles inland from the Ribble estuary.

All in all, the 'staithes' are not very helpful in identifying the system of waterways in use in early medieval times. Only two are recorded early enough, and in neither case do they link up with the road network. Most examples occur in north-west England, particularly Lancashire, and, as several contain the $\mathrm{ON}$ term, they are likely to have developed as a result of the activities of the Vikings and their descendants around the Irish Sea coast and a short distance up the estuaries. The eastern examples Burton Stather and Flixborough Stather were in Viking-frequented territory accessible from the Humber.

\section{$L \tilde{A} D^{17}$}

There has been some uncertainty about the meaning of läd in place-names. Ekwall, 1960 , says 'OE lâd seems to mean 'water course' when used in place names ... OE gelād appears to mean 'passage over a river'. Smith concurs, and adds that lād and gelād fell together as Middle English lode; on the river Severn lode came, in effect, to mean 'a ferry', while Modern Dialect 'lode' came to mean a water channel especially in the Fens.

Margaret Gelling notes that $l \bar{a} d$ is occasionally used in minor names to mean a track as in Loads Farm DRB, but usually referred to 'a dyked water-course, a canal'. Läd, therefore,

\footnotetext{
16 Tim Pestell and Katherina Ulmschneider (ed.), Markets in Early Medieval Europe: Trading and Productive Sites, 650 - 850 (Macclesfield, 2003), pp. 7, 29.

${ }^{17}$ These are listed in fig. 6.13 and mapped in figs 6.12 and 6.16.
} 
seems to have been used to describe a watercourse; occasionally nearby settlements took their names from the watercourse.

The majority of läd names come from the Fenland, records of them are to be found in the cartularies of the monasteries. Sir William Dugdale ${ }^{18}$ writing in 1662 lists scores of them. It is clear that by the end of the middle ages The Fens contained large numbers of lodes $(\mathrm{OE} l \bar{a} d)$; they were for drainage or navigation, sometimes both. It is known, for instance, that the monks of Sawtry brought Barnack stone along a man-made channel for the building of their abbey, for it was the subject of a dispute with Ramsey Abbey in 1192. Although Dugdale describes so many lodes in his 1662 book, it is not known where most of them were because the landscape of the Fens was transformed by the drainage works of Vermuyden and others in the mid-seventeenth century. Most of the old, man-made channels were replaced by straight, new drains, and so their routes were lost; more especially with so much shrinkage and erosion of the peat the traces that might have survived have disappeared. However, the pre-drainage river courses can often be identified because the silt of their beds and banks did not shrink and erode like the peat did, and so they stand out as roddons - sinuous raised banks of silt. The whereabouts and names of just a few lodes have survived as the names of farms, and are discussed below.

Archaeology and fieldwork can also identify man-made waterways. In Fenland, Car Dyke is recognised as Roman, while the three leading from the fen edge to the Cam (Bottisham, Swaffham Bulbeck and Reach Lodes), once thought to be Roman, are now thought more likely to be early medieval (see below). Others also thought to be early medieval are Cnut's Dyke (first evidenced in 1285), King's Dyke (c.1250), Burwell Old Lode (1659), Monk's and Wicken Lodes (1636), Cottenham or Chear Lode (1291), Darcy Lode (1617), Rolls Lode (1617) and Fenton Lode (1248). None of these are evidenced before the mid-thirteenth century.

There are then, surviving names of early medieval, lost, artificial waterways; there are surviving early medieval waterways with names recorded no earlier than the thirteenth century. Either way, the evidence from place-names is of limited use in identifying artificial watercourses used as navigation canals before the Conquest. The material is even more limited if only settlement names are used, as in this study. As explained in chapter 1 the evidence is more evenly balanced and produces a fairer picture if the names of lesser features are omitted. This is particularly true in the Fens which are covered well by PN CAM, but which is not dealt with in any detail in PN HNT, and not yet covered by the PN LIN or PN NFK (this is equally true of the Somerset Levels).

In spite of all these problems there are a few place-names which can be used. Chief of these is Whaplode LIN, the only läd recorded in DB. 1t was on the silt fens close to the Anglo-Saxon coastline; the läd may have been a channel linking the settlement to the Wash. There are five other examples of läd in settlement names in the Fens. Three of them are names of farms near Car Dyke: Holwoods House, Horslode Fen Farm and Crollode's Farm. Car Dyke is thought to be a canal dug by the Romans linking various natural waterways, and in so doing providing a route from the Cam to the Trent; it was earlier known as Tillinge (1235). The Anglo-Saxons probably recognised that Car Dyke was manmade because of the spoil banks either side, and as their term for a man-made waterway was läd, the adjacent settlements incorporated this term; they probably refer to Car Dyke but could refer to short waterways leading off Car Dyke.

Lode CAM (1154-89), is at the head of Bottisham Lode, which along with Swaffham Bulbeck and Reach Lodes were once thought to be Roman canals. They lead into the Cam

\footnotetext{
${ }^{18}$ William Dugdale, A History of Imbanking and Draining of divers Fenns and Marshes, edited and revised C.N.Cole ( $2^{\text {nd }}$ ed. London, 1772).
} 
and thence have access to other Fenland waterways. David Hall ${ }^{19}$ writes that there is no satisfactory evidence that these are of Roman origin, but he believes that they are early medieval in date. Bottisham Lode must have been in existence by the second half of the twelfth century when Lode is recorded, but this does not tell us whether the other three lodes were dug in Roman times or if they were part of an Anglo-Saxon waterway network or not. However, Laddus (Farm) is noted in c. 975 and so the lactwere ('lode-weir') must have existed in Anglo-Saxon times. It lies close to the old course of the river Nene, although whether the läd was the Nene or a feeder to it is unknown.

There are five or six lāds in the Somerset Levels (see map: fig. 6.12). This is another area so marshy that to travel by water was far easier than to go overland. The addition of short lengths of man-made waterways to link existing rivers to settlements in and around the marshlands would have made this more efficient. A short canal, Northload, the name surviving in Northload Bridge, enabled one to reach Glastonbury from the old river Axe; excavations have shown this to be Late Saxon; ${ }^{20}$ another Northload provided a means of reaching the south-eastern part of Wedmore from the Axe. Long Load and Little Load are either side of the river Yeo about 4 miles downstream of Ilchester, which had had port facilities in Roman times. The Yeo is said to have been canalised for transport, ${ }^{21}$ and this might account for the name, but equally a short canal from the Yeo to the settlement of Long Load might have existed and account for the choice of name - either way the use of the Yeo is indicated.

There are no records of pre-Conquest drainage in the Somerset Levels, but the later diversion and drainage works in the south-western part of the Levels by the river Tone have been considerable. The river Tone once flowed between Lyng and Athelney; the northern remnant is called the West Yeo today; the diversion of the Tone away from the Lyng/Athelney gap (dotted line on map) took place in 1374-5. Curload is adjacent to this new cut and yet there is a reference to Hugh de Curylode ${ }^{22}$ in 1250 implying there must have been an earlier cut called 'Curry Lode' perhaps linking the old course of the Tone (continuous line on map) to the Curry 'peninsula'. Upstream the present course of the Tone is also artificial; the earlier course was that of the Old Rhyne (continuous line); the latter is followed by parish boundaries but there are no records of when the diversion was carried out, although it is likely to have been well before 1374-5, otherwise the re-routing of the Tone near Curload would not make sense. These uncertainties of timing make it difficult to set Cogload, also near the Tone, in context. It is recorded by 1269 in the Cartulary of Buckland Priory, ${ }^{23}$ but one cannot tell whether it was a short water-course leading to the Old Rhyne or a longer one to the diverted (present) course of the Tone.

The last possible example of lād in Somerset is Shiplate, discussed under gelād in the appendix. If it is an example of a lād the eponymous watercourse is likely to have linked settlement on Bleadon Hill to the river Axe.

Clevelode WOR, like Shiplate, could be derived from either gelād or läd (see appendix). It is close to the Severn where a small, winding tributary running close by the foot of the eponymous clif enters the river. It seems unlikely that a man-made watercourse would

\footnotetext{
${ }^{19}$ David Hall, 'The Fenland Project, no. 10, Cambridgeshire Survey, Isle of Ely and Wisbech', East Anglian Archaeology, 79 (1996), p. 112

${ }^{20} \mathrm{C}$. and N. Hollinrake, 'The Abbey Enclosure Ditch and a late Saxon Canal', Somerset Archaeological and Natural History Society, 136 (1992), p. 73

${ }^{21}$ CDEPN, s.n. Load

${ }^{22}$ Calendar of the Mamuscripts of the Dean and Chopter of Wells (2 vols, Historic Manuscripts Commission 12, 1914), 2, p. 224

${ }^{23}$ Cartulary of Buckland Priory, ed. F.W. Weaver (Somerset Record Society, 25, 1909), p. 36
} 
follow such an unnecessarily winding course. The läd in Clevelode may therefore be a reference to a ferry like Hampton's Lode nearby.

The very small number of DB or earlier references to la d means that it is of limited use in identifying early canals contributing to the network of navigable waterways in the Anglo-Saxon period. Such names as there are imply that these artificial water ways were cut through marshy ground, usually peat or alluvium, to link higher, firmer ground with a navigable water way. Those likely to be of Roman origin, Car Dyke and possibly Bottisham Lode, were much longer than those of possible Anglo-Saxon date.

\section{SKUTHR}

This ON term meaning 'a cutting, a canal' and, absorbed into the Lincolnshire dialect, occurs as the name of a few water-courses in south Lincolnshire such as Billinghay Skirth, but there is only one settlement name, Skurff Hall YWR, recorded in the thirteenth century. It is of particular interest because it is only 1 mile from Drax (OE drag with ON drag substituted) 'place where things are dragged'. $S$ mith $^{24}$ describes nearby Hawday Lane as an old course of the river Aire (Hawday derives from ald-e ea). In fact a ditch runs from the river Aire to Skurff Hall and beyond; it is narrow, deep-cut, sinuous in places and certainly not navigable today. There do not seem to be any other references to this being an old course of the Aire. The name Skurff is strongly indicative of an artificial waterway, and the presence of Drax nearby suggests that boats were pulled through it. Its Scandinavianised form drag and the use of the ON term skuthr imply a Scandinavian usage - namely a portage. The factors against this interpretation are the inappropriateness of the water-course today, and why anyone should want to go to the trouble of portaging along this two and a half to three mile route when it is only six or seven miles round by river. Conditions 1,000 years ago were different, and it could be that an old water course was silting up and that it was having to be kept open artificially and was hence regarded as a 'canal' rather than a river.

\section{$\bar{E} A-T \bar{U} N^{25}$}

$\bar{e} a-t \bar{u}$ means 'river settlement'. That some 30 out of many hundreds of riverside settlements should be so called suggests that the $\bar{e} a-t \bar{u}$ s are somehow special, and that they may be further examples of functional tüns, and that the function is related to their being beside a river. The two most plausible suggestions are that they are sites of ferries, or that they have a duty of keeping the river open for navigation and perhaps organising such use. ${ }^{26}$ A consideration of their distribution suggests that the latter is the more likely. Most of the $\bar{e} a-t \bar{u} n$ s occur on major rivers such as the Thames, Severn, Wye, Great Ouse, Trent and their larger tributaries, and especially on their upper reaches. If the function of an $\bar{e} a-$ $t \bar{u}$ was to provide a ferry service one would expect them to be on the lower, wider, deeper reaches, mostly downstream of any fords; apart from Eton BUC, this is not so. If the function was to keep the river open for navigation one would expect the éa-tuns to be much further upstream, where the river was becoming so narrow and shallow that it would be difficult to avoid any obstacles such as slumping banks, encroachment by rushes and reeds, shoals and fallen trees, by navigating round them. This is where the majority of $\bar{e} a-t \bar{u} n$ sare: near the upper limits of navigation for any craft big enough to be useful for carrying loads. In these upper reaches punt-like crafts propelled by quanting (poling) would be feasible since they draw only a small draught and, being oar-less, need only a narrow waterway. On the Upper Thames for instance, Eaton is by a wide stretch of Thames, but in a place where

\footnotetext{
${ }^{24}$ PN. YOW 4. pp. 9-10.

${ }^{25}$ These are listed in fig. 6.14 and mapped in fig. 6.15.

${ }^{26}$ Gelling and Cole, Landscape, p. 14.
} 
the banks are slumping into the river and it needs to be dredged. Further upstream near Eaton Hastings, Castle Eaton and Water Eaton the common club rush, Schoenoplectus lacustris, growing in great clumps in mid-stream can block the channel, although where the children play in a small stretch passing their back gardens in Castle Eaton the river is kept clear and usable. Near Water Eaton, just below Cricklade, the erosion of the ēg of Eisey produces sand banks in the Thames, which in any case is only just navigable at this point. A boat was taken up as far as Cricklade in the 1980s, but with considerable difficulty because of the choking of the channel by aquatic plants. ${ }^{27}$ The $\bar{e} a-t \bar{u} n \mathrm{~s}^{\prime}$ function of keeping the Thames open for navigation would have been important because at Cricklade it is crossed by the Roman road from Silchester to Cirencester (M 41b), and at Lechlade it passes the end of a salt way from Droitwich, thus linking river and overland transport. A number of other $\bar{e} a-t \bar{u} n s$ are situated where the upper reaches are within easy reach of a Roman road or other old routeway, so they may have been responsible for the transhipment of goods as well as keeping the channel clear.

In those $\bar{e} a-t \bar{u} n$ s by wider rivers the duty of keeping the water open for navigation may have had a different emphasis as six of the nine examples are also close to fords (see vol. 2, pp. 214-7 for details). At a fording place there is a conflict of interests; the overland traveller wanting the water to be as shallow as possible and the boatmen wanting it to be deep enough for their craft. Maintaining the ford in good condition and to suit both groups could therefore be a function of the $\bar{e} a-t \bar{u} n s$. In later years, when fords had been superseded by bridges, keeping the piers free of flotsam brought down, especially in times of flood, would have been useful.

Thirty-three possible examples of ēa-tīn are listed in fig. 6.14; as four are doublets (HRE, OXF, YON 2) they refer to 29 different reaches. One example, in CHE, is uncertain, leaving a core of 28 . A high proportion, 22 of the 28 , is recorded in DB and some even earlier, an indication of their importance. Eleven of these are within easy reach (two miles) of main Roman roads, one of a minor one, and four are within two miles of other old routes. Five are more than five miles from old routes, including East and West Ayton on the Derwent where river transport through the swampy Vale of Pickering was much more practicable than overland transport. Great and Little Ayton appear to be so high up the river Leven that it can only have been navigable there in periods of unusually high flow - if then. The efforts made to keep narrow, marginally navigable headwaters open and functional until they are within easy reach of the road system indicates an extensive use of rivers by punt-like, load-carrying, small boats, maybe for only short distances within large estates, maybe for longer journeys. They show that the upper reaches of the Severn and Wye were in use although there are no hÿth place-names along their courses.

Two of the five post-DB éa-tūns are by short streams; Eton by the Banwell SOM was not part of a large route-way network but served local, reclaimed marshland and linked the Mendips with the Bristol Channel; likewise Eaton NFK, on the short Heacham River, only served to connect the Wash with the Peddar's Way. Eaton under Heywood SHR, linked into a weg - Stanway, and Eaton SHR provided a link to the Portway over the Long Mynd. These later-evidenced e $a$-tūns linked not with Roman roads but with other old routes, but with such a small sample this may be no more than coincidence.

The $\bar{e} a-t \bar{n}$ s are useful in identifying the route-way network of Anglo-Saxon England.

${ }^{27}$ K. Taplin, 'Beyond the Limit', The Countryman, 97 no.5 (1992) pp. 65-70. 


\section{The Waterway Network}

The larger symbols on the map (fig. 6.16) shows the port, hÿth, stceth, stoth, läd and éatün names evidenced by $\mathrm{DB}$, and this gives a minimum picture of the waterway network in use in the early medieval period. Smaller symbols represent post-DB examples

There is a good series of landing places (two hyths and six ports) extending from Creeksea and Pudsey in Essex, round the Kentish coast, along the English Channel coast and into the Bristol Channel. Many of these are well placed for cross-channel trade with France and the Low Countries. As port is a borrowing from Latin, and likely to be a term in use in the early years of the Anglo-Saxon period, it suggests that the cross-channel contacts, be they for raid or trade, had been present since the end of the Roman period (and indeed centuries before). Toxteth and the puzzling Huyton in Lancashire suggest contacts across the Irish Sea, more particularly with the Scandinavian settlers around Dublin, since Toxteth is most probably an ON name; Edmonds demonstrates that there was other, nonplace-name evidence of cross-Irish Sea traffic. ${ }^{28}$ At this time there is no place-name evidence north of Essex of trans-North Sea traffic with Scandinavia, but this absence of place-name evidence cannot be taken as proof that routes did not exist or were not in use.

Evidence for river traffic as demonstrated by $h \bar{y} t h$ is concentrated along the Thames, especially in the vicinity of London. The $h \bar{y} t h$ names here give some idea of the cargoes carried - chalk at Chelsea, lambs at Lambeth and (slightly later) cattle at Rotherhithe. The series of DB hyths extends up-river to Bolney (bullocks hithe) near Henley-on-Thames; Hidden is on the Kennet, a tributary of the Thames. The only other major river with a hy $t h$ place-name is the Trent, where Knaith is fairly well placed for traffic using both the river and the Foss Dyke. Two fen-edge hỹths, Lakenheath and Otringhithe, allowed access into East Anglia through the Little Ouse system from the west - a difficult direction from which to approach because of the Fenland marshes cutting East Anglia off from the East Midlands. Swavesey links the Great Ouse to the Roman road system.

The distribution of the many DB $\bar{e} a-t \bar{u} n$ s indicates that there were many other stretches of river pressed into service. The four on the Thames above Oxford show that the Upper Thames was a well-used waterway leading into the heart of the south midlands, linking into the Roman road system at Cricklade and the salt ways at Lechlade, and that it was worth some effort to overcome the problems associated with smaller rivers, such as blockages and variable flow, which could delay navigation at times.

The presence of three DB éa-tüns on the upper Wye in Herefordshire, and of three more on the headwaters of the Severn in Shropshire, shows that in spite of the lack of hyths on these two rivers, they too were in use and worth keeping open. There would have been no need for $\bar{e} a-t \bar{u} n$ s on the lower reaches of the Severn; the lack of indicative place-names there does not mean that the river was not in use.

Other $\bar{e} a-t \bar{u} n$ indicate that many other rivers were pressed into service - quite substantial ones like the Great Ouse and its tributary the Ouzel, both $\bar{e} a-t \bar{u}$ s seemingly placed to keep these rivers open to a point where there is nearby access to the road network. Nuneaton WAR, and Water Eaton STF, on tributaries of the Trent seem to perform the same function.

Considering now the post-DB place-names: changes in the water transport system were occurring at the end of the Anglo-Saxon period and into the next couple of centuries, notably in the numbers of $h \bar{y} t h$ names appearing in the marshlands, as the religious houses, with growing wealth and power, were able to undertake ambitious 'canal' construction to meet drainage and transport needs, especially in the Fens and Somerset Levels (Hive in

\footnotetext{
${ }^{28}$ Fiona Edmonds, 'Barrier or Unifying Feature? Defining the Nature of Early Medieval Water Transport in the North-West' in Blair, Waterways, pp. 21-36.
} 
YOE should be regarded as one of this group in spite of its pre-DB appearance in the records). These were essentially local networks of waterways, albeit on a large scale. The situation at Eton SOM, is similar but on a very much smaller scale. The la ds were part of this expansion too, allowing boats plying the natural waterways to get through the fringing marshes to reach and load/unload by firm ground. More $h \bar{y} t h$ s are evidenced from the south-east; many of them just a short distance up estuaries. Some, like Small Hythe KNT, and Bulverhythe SSX, would have been involved in coastal trade; a few, such as Heath Barn SSX, Eaton (Sedgeford) NFK, and Old Heath and Hythe ESX, tied into the road network. The developing use of the Trent with its links to the Witham and Yorkshire Ouse was exemplified by the appearance of Stockwith and Walkerith. This still left large areas in the north-eastern counties apparently without water transport according to the place-name evidence; this is partly because the east-flowing Pennine rivers are little use for navigation in the Dales, and partly because the north-east coast was not quite so well positioned for overseas trade as the south and south-east coasts, or even because such names have not come down to us. The north-west coast fares better with examples of hithes and staithes reflecting the contacts between the Scandinavian-founded settlements at Dublin and York. Overall the Thames and the south and south-east coasts seem to have been the most important waterways throughout the early medieval period. 


\section{CHAPTER 7}

\section{OTHER PLACE-NAMES LINKED WITH ROUTEWAYS}

The place-names in this group occur by routeways but are not descriptive of the route itself, although by describing features that travellers would recognise, they would enable them to estimate how far along their journey they had come. Two of the terms (ceaster and wic-hām) refer to places where there were, or had been, buildings; two (cumb-tūn and denu$t \bar{u}$ ) refer to landforms (valleys) and one (netel, nata) to vegetation. The travellers would recognise many other features as they passed that were randomly distributed with respect to routes, such as diuns and beorgs (hills), and therefore of little help to them in finding their way. The five name types above are large groups which are consistently found beside Roman roads and old routes. They would know that at the ceasters and near the wic-häms there would be the remains of Roman settlements, often towns or forts, some parts perhaps in use, and some with adjacent Anglo-Saxon settlements or gathering places. They would almost all be on important Roman roads, the ceasters often at road junctions. These names do not tell us if the roads were in use in Anglo-Saxon times, but they refer to significant and easily recognised landmarks en route. Some sort of settlement in a valley is implied by the names cumb-tün and denu-tūn. Even if the traveller was not concerned with finding these settlements, they could be useful landmarks. The cumb-tüns occur in a comparatively small but easily recognised landform (a bowl-shaped hollow), frequently in sight of a routeway but probably not offering any particular facility to the traveller. Since most denus refer to much larger valleys than cumbs, any denu-named settlement could be on a variety of sites in the valley, and so they would not help travellers to locate themselves precisely; only where the denu is short, and the choice of settlement site is limited, is there likely to be a denu-tün of locational use to a traveller.

The elements netel and nata seemingly have nothing to do with route-ways; yet, when investigated more closely, they prove to have links with the movement of animals, particularly pack and drove animals. There may well be other place-names, as yet unidentified, which also have associations with routeways.

\section{OE CEASTER, CAESTER}

ceaster is defined as 'city, walled town, fortification' and is a borrowing from Latin castrum 'camp, fort, town'. 'The term is mostly applied to Roman forts or towns but occasionally to Roman villas, or earthworks such as Iron Age forts. It might be supposed that all ceasters were on or close to Roman roads, but this is not invariably the case as noted below and in figs 7.1 and 7.3. The corpus has been divided into two groups: firstly 'ceaster + element', and secondly 'ceaster' simplex and 'element + ceaster'. The former is the smaller group consisting of eight examples of 'ceaster + tün', two or three of 'ceaster + ford' and seven others. Chesterton/Casterton has the sense 'settlement near a castrum', the ceaster and the tün being up to $1 \frac{1}{2}$ miles from each other. Seven of the Chestertons are recorded in DB or earlier; they lie within 11/4 miles of a Roman road, and six of them are within 11/4 miles of a Roman settlement (none is known at Casterton WML). The eighth example is Chesterton SHR: it is not evidenced until 1214, refers to an Iron Age (?) hill-fort, and is $2 \frac{1 / 4}{4}$ miles from a minor Roman road. Chesterford ESX, YOW, are both recorded before DB, are on Roman roads and on the sites of Roman settlements, whereas Seighford STF, although in DB, is not near a Roman site or road and is not a safe example of a ceaster. ${ }^{2}$

\footnotetext{
${ }^{1}$ Parsons and Styles, Vocabulary: Brace-Cester, p. 158. A fuller discussion can be found in Bell, Religious.

${ }^{2}$ CDEPN, s.n. Seighford
} 
Of the seven 'ceaster + element' examples, Castley YOW is an uncertain one and is not by a Roman road. Chesterhope NTB is close both to a Roman road and a Roman settlement; Chesterwell ESX is by an earthwork and close to a Roman road. Chesterblade SOM is near an Iron Age camp but not by a known Roman road, although it is only $2 \frac{1}{2}$ miles from Stony Stratton, which itself is not adjacent to a known Roman road, but suggests there might be an unidentified one in the vicinity. In Cesters Over WAR, the original place-name was Wafre (DB); Cesters was added by 1242 ; it is near a Roman road but not a settlement. The other two examples, Cheshunt and Chiselbury Camp, are associated with funta, the term thought to refer to a spring Romanised in some way: Cheshunt HRT is on a Roman road, and its second element is funta; Chiselbury WLT is thought to derive from ceaster + slaed + burh, the burh being the Iron Age hill fort; a small valley with a stream in it $3 / 4$ mile to the southwest could be the slced; Fovant, having another funta name, lies in this valley. It is possible that ceaster in these two places is associated with the works around the springs, for there seem to be no Roman settlements known at these sites.

In the majority of names ceaster is the generic; most of them are mentioned in DB or earlier, except in the northern counties. With a few exceptions, the settlements are within a few hundred yards of the site of a Roman town or fort, and they are on, or within $1 / 4$ mile, of a Roman road. The exceptions are three which refer to birds: Craster (crows), Hincaster (hens) and Outchester (owls). Here there is a parallel with the burh names; just as 'bird name + burh' is thought to refer often to abandoned strongholds, so the 'bird + ceaster' names may refer not to Roman settlements but to earthworks where no Roman remains are known. They are not near Roman roads, and two of them not evidenced until the thirteenth century. This facetious name-type would have been familiar to the Anglo-Saxons who would have realised that the reference was not to the usual Roman ruins. The other exceptions are Chesters and Rudchester NTB, forts on Hadrian's Wall, Whitchester which refers to Hadrian's Wall itself, Frocester GLO, which refers to a Roman villa, and Woodchester GLO, which also refers to a fine Roman villa but is $23 / 4$ miles from a known Roman road. Caistor near Great Yarmouth is in Flegg, in Roman times an island lying on the northern flank of the Great Estuary, and therefore not near the main road-system. Brancaster is on the north Norfolk coast and not on the main road system but was probably linked by a minor road westwards to $M 33 \mathrm{~b}$ at Holme-next-the-Sea. ${ }^{3}$ Acaster Selby and Acaster Malbis are on the Ouse downstream of York, the name incorporating ON $a$ which probably displaced an earlier OE $\bar{e} a$. They are said by Watts ${ }^{4}$ to be forts protecting York from attackers sailing up the Ouse, but Smith $^{5}$ says no trace of the supposed forts has survived, nor do any appear on the O.S. Map of Roman Britain. The name would inform any traveller that this was a riverside settlement and not necessarily on the main road-system. Scobchester DEV, is the most anomalous of all the ceasters as it is not near any known Roman road, nor any known earthworks or Roman ruin, nor is it evidenced until 1242.

The term ceaster was current in the early days of the Anglo-Saxon settlement (unsurprising as it is a borrowing from Latin). It makes a good showing in Cox's list of 'The Place-Names of the Earliest English Records ${ }^{66}$ where 15 names referring to 14 places are listed as occurring by 731 . It includes several places whose names have since changed: Reptacaestir now Richborough KNT, Uaeclingacaester now St Albans HRT, and several lost names. For travellers in the early medieval period ceaster would be a helpful and informative place-name. They would be looking out for stone walled buildings, and since the early Anglo-Saxons rarely used stone it would not have been robbed out, and so the walls

\footnotetext{
${ }^{3}$ Peter Wade-Martins (ed.), An Historical Atlas of Norfolk (Norwich, 1994), p. 35.

${ }^{4}$ CDEPN, s.n. Acaster.

${ }^{5}$ PN. YOW 4, p. 218.

${ }^{6}$ Cox, Place-Names, pp. 12-66.
} 
would have been prominent features. (The charter boundary mark cealc-weallas 'limestone walls', in the bounds of Turkdean GLO (S 99) refers to a large Roman villa in the adjacent field, commenting on just such a survival). Travellers would be aware that the ceasters would be on well-constructed roads, and that many were at road junctions and /or river crossings; there are known to have been Roman bridges at some of them. Whether or not the ceasters would have been lively, busy settlements would have depended on the date under consideration, since they were abandoned when Roman rule broke down, only for some of them to be gradually revived as sites chosen for churches and monasteries, followed by the trading activities that often developed by such institutions. ${ }^{7}$ For travellers though, the term ceaster would have carried no information as to whether the site was inhabited or not; it was primarily a landmark consisting of stone-built walls. Only when towns were growing apace would the accelerating change in the appearance of the ceasters, from that of ruined masonry with rather little human activity to ones with their own individual layouts, buildings and activities, enable a traveller to distinguish them readily from each other. Ceaster can only be used as evidence that a Roman road and settlement once existed provided that it is evidenced by $\mathrm{DB}$ and does not carry within the name a warning that it is no ordinary ceaster.

\section{OE WIC-HÄM}

The term wic-häm occurs in over 40 field and settlement names. In its modern form it appears as Wickham, Wyk(e)ham etc. Wic is a loan word from Latin vicus. Gelling ${ }^{8}$ suggested it might have been used 'by the earliest English-speaking people in Britain to refer to actual Romano-British settlements or to Roman administrative units' and demonstrated that a high proportion of examples referred to places with remains of substantial Roman settlements. This study was updated in Gelling in $1988 .{ }^{9}$ She noted a good, but not perfect, correlation with important Roman roads but commented that 'the true connection is between wic-häm and small towns rather than between wic-häm and roads'. There are 25 settlement names including two pairs, of which the sites of 24 are known; see fig. 7.2 and map: fig. 7.3. These are plotted on the dispersion graph: fig 7.6, counting each pair as one. There is a dense cluster up to $13 / 4$ miles of a major Roman road or, in one case, the Great Ridgeway. Of the seven which do not conform to this pattern, Wykeham OXF is on a minor Roman road, and Wykeham YON is on an old route on the northern side of the Vale of Pickering; the lost Wickham in Strood KNT was about 2 miles from M 1 (London to Canterbury); M 340 from Baylham is heading towards Wickham Market SFK but disappears from the landscape $2 \frac{1}{2}$ miles short of it. Wickhambrook SFK is about 8 miles from the nearest Roman road but it is only $1 \frac{1 / 4}{4}$ miles from Stradishall, a strāet name, suggesting that there is an undiscovered Roman road in the neighbourhood. Two, Wykeham near Spalding LIN and Wickham Farm in Icklesham KNT, were beside estuaries. The correlation with old routes is therefore good.

As noted, the real connection of wic-häm was with settlements rather than roads, but any settlement would need to be accessible by road (or perhaps water), and so a correlation between wic-häms and roads follows. It does not necessarily demonstrate that the road was in use, but it very likely was if the $w \bar{i} c-h \bar{a} m$ and/or its adjacent Roman settlement were functioning settlements. The term wic-häm is unlikely to have arisen in response to the perceptions of travellers only, but to the general recognition that here was a settlement adjacent to a Roman one which was possibly still functioning in some way. The name would

\footnotetext{
${ }^{7}$ Tyler Bell, The Religious Reuse of Roman Structures in Early Medieval England (BAR British Series 390, 2005). Bell describes the uses to which Roman structures, including ceasters, were put in the early medieval period. See especially pp. 15-7 and chapter 3

${ }^{8}$ Margaret Gelling, 'English Place-Names Derived from the Compound Wìchām', Medieval Archaeology, 11 (1967), pp. 87-104.

${ }^{9}$ Gelling, Signposts, pp. 67-84.
} 
be informative for travellers, who would know what to expect at such a place, which, indeed, might have offered useful facilities to a traveller, but that was not the reason for the name becoming attached to the settlement in the first place. The name wic-häm is useful supporting evidence for a road in use

\section{OE CUMB-TŪN}

The term cumb is used of valleys that are short in comparison to their width - generally described as bowl-shaped, but really more like an armchair: the rim is low on one side, giving access to the hollow. Their distribution is almost entirely southwest of Watling Street, with major concentrations in Devon, Dorset and Somerset. This is largely the result of the geological structure of England, as the scarp-lands provide ideal conditions for their formation. They are typical of scarp slopes, where any valleys that develop are likely to be steep and short, whereas the long, gently sloping dip-slope valleys are typical denus. There are types of topography other than scarp-lands in which cumb-like valleys are found, notably in Devon, where most valleys were regarded as cumbs. ${ }^{10}$

The form 'element $+c u m b$ ' is used of settlements well scattered over southern England. Examples occasionally correlate with routeways, because old routeways so often follow scarp crests which overlooked the coombes eroded into the scarp slopes. However, a sub-set of cumb names, the cumb-tüns, shows a remarkably close correlation with routeways (see dispersion graph: fig. 7.6, list: fig. 7.4, and map: fig. 7.5). There are 44 examples of cumbtün including four pairs. The sites of two, both in Staffordshire, are unknown: one in Sussex survives only as the name of a wood.

The dispersion graph plots only one of each pair - the nearest to a route. There are therefore 40 examples plotted, of which 27 are at or within 1 mile of a Roman road, ancient track or old route $(67.5 \%)$. Eighteen of the 40 are at or within 1 mile of the Roman roads and ancient tracks shown on the O.S. Map of Roman Britain (45\%), well above the $16.5 \%$ one would expect if the distribution was random. Only five are likely to be more than $11 / 2$ miles from an old route; one is on the Isle of Wight, and two are places whose sites are unknown. The inter-quartile range is low at 1 mile.

A traveller following a scarp-crest would have little difficulty finding a view of the scarpslope topography, and would see from time to time settlements tucked into coombes and bearing the name cumb-tūn, for example Compton Beauchamp BRK, Compton Abbas, Compton Valence and West Compton DOR, Compton SRY and Compton Chamberlayne WLT. They would also see others bearing quite different names, as in the series between Shaftesbury and Blandford Forum: Compton Abbas, Fontmell Magna, Sutton Waldron and Iwerne Minster, all close to the Great Ridgeway. Cassey Compton and Compton Abdale GLO both lie on a salt- route from Droitwich, and are the only two settlements on the dry limestone stretch of this route through the Cotswolds. The only cumb-tün north of Watling Street lies close to a Roman road - only $13 / 4$ mile north of $M 72 b$ from Ilkley to Tadcaster.

The correlation between old routeways and cumb-tüns is clear, but the reason for it is less so. They do not appear to have any particular function like the drag-tūns and strēt-tūns have, so how is it that so many cumbs by routes are called 'cumb-tīn' rather than 'element + cumb'? As discussed in chapter 1, the perceptions of travellers may have played a part. In exchanging information about the nature of a route it would be possible to call attention to a settlement in a cumb without calling it by a proper name like Tidcombe or Letcombe but simply referring to it as the 'cumb settlement' i.e. cumb-tūn, - Compton. For a traveller, a cumb-tün may have served only as a landmark along a route and not been associated with any sort of function useful to the traveller. They can serve as useful confirmatory evidence

${ }^{10}$ For distribution maps see Gelling and Cole, Landscape, pp. 105, 122, 134. 
for old routes, particularly as such a high proportion, 31 of the 40 , is recorded in or before DB

\section{OE DENU-TŨN}

Since the Comptons correlate well with old routes, it seemed worth investigating whether the Dentons did too. There are far fewer examples of denu-tūn than cumb-tün, just 16 including one pair: not a big enough sample to apply a statistical test to, but they are shown on the dispersion graph: fig. 7.6, and map: fig. 7.5. Two Dentons I have not been able to pinpoint, but they must be near old routes as one goes through each parish in which these Dentons occur: a Roman road in the case of Denton CHE, and the Great North Road in the case of Denton in Stannington NTB. Nine of the remaining 14 are within a mile of a Roman road, Sewstern Lane or a salt way $(64 \%)$.

A denu is a valley long compared to its width; even so, they vary greatly in length. It is difficult to be precise about the length of a denu because it is not possible to decide just where a denu starts and finishes. Nevertheless, it does seem that denu-tüns are in the shorter valleys where there may be room for only one or two settlements and not a whole series. That being so, any settlement in a short denu is likely to be the denu-tün, and can be identified by this general term in the same way as the cumb-tüns can. The names would have originated in the same way as the cumb-tūns. They are less useful as confirmatory evidence of routes because there are fewer of them, a lower proportion were recorded by the time of $\mathrm{DB}$, and the link with routes cannot be statistically tested.

\section{OE NETEL, ON NATA.}

The occurrence of netel and nata in place-names has been described in JEPNS. ${ }^{11}$ Nettles grow best where there is a high phosphate content in the soil, and this occurs where there has long been a concentration of humans, animals or their remains: it can persist in the soil for centuries.

Fig. 7.7 shows that some examples are associated with Roman settlements. Others are close to Roman roads and probably represent watering or resting places for travellers with animals Nettlebed OXF, has ponds and Nettleton GLO, has springs, both are amid dry uplands. Some are by bottlenecks which concentrate animals, as at Nettlebridge (earlier Nettleford) SOM, and Nettleford CHE. Some are by old, but non-Roman routes: Natrass CMB, and Nateby WML, LNC, were on drove roads and probably holding areas for animals prior to sale in nearby markets. Nettlehope Hill NTB, lies on a monastic route later used as an eighteenth century drove road. Nettleworth NTT, by Leeming Lane, and Netley SHR, on the Leominster to Shrewsbury route, are evidenced long before the routes are recorded. They suggest the routes were used centuries earlier than existing records imply.

Although netel and nata have some value in identifying old routeways there are two main limitations to their usefulness in this study: firstly, the limited number of spellings dating back to the eleventh century, and secondly, the impossibility of knowing whether those by Roman roads indicate that the road was still in use or not.

The examples of ceaster and wic-häm, because they normally refer to old Roman settlements, are perforce adjacent to Roman roads, and therefore helpful landmarks for travellers, but they were not named with the travellers' needs in mind; the cumb-tüns and denu-tüns do appear to have acquired their names from travellers. If they were not travellers' landmarks they would surely occur in situations distant from old routes just as many of the

\footnotetext{
${ }^{11}$ Ann Cole, 'The Use of Netel in Place-Names', JEPNS, 35 (2003), pp. 49-58; 'The Use of ON Nata in Place-Names', JEPNS, 36 (2004), pp. 51-3.
} 
'element $+c u m b$ ' and 'element + denu' names do. Just why these particular cumbs and denus were picked out is uncertain. It is possible that they were visible from customary resting places, perhaps a day's or half a day's journey from the last overnight halt. Netel and nata are not very useful indicators of roads-in-use in the context of this thesis, but they do show that place-names, which at first sight do not have any link with travel may in fact do so. There may well be others yet to be discovered. As noted in section 1 of the Appendix some corpora are randomly distributed with respect to travel routes, for instance, the äc-tüns, the gréots and the sloeps. The halh-tüns and höh-tüns were tested and showed no correlation, nor do many other purely topographical names such as those incorporating fleot or dün. One would not expect the 'personal name $+t \bar{n}$ ' or 'personal name $+b y$ ' to correlate. It is quite possible that other placename corpora correlating closely with old routes will be discovered; in fact one such chance discovery is the subject of Chapter 8 . 


\section{CHAPTER 8}

\section{PLACE-NAMES USED AS LANDMARKS ON ROUTEWAYS}

Most of the place-names discussed so far describe the nature of the routes and the facilities available by them: Anglo-Saxon equivalents to the road classification system, the filling stations, cafes, hotels and the rescue services such as the A.A. and R.A.C. Modern travellers also have huge road signs giving destinations on major routes, signposts on lesser routes, signs showing settlement names, and a plentiful and varied supply of maps, but they also have to contend with a more complicated network of major routes and a much faster means of travel, with little or no contact with the people living alongside. How did Anglo-Saxon travellers find their way? Was there an Anglo-Saxon equivalent to the signpost? There are no surviving maps; perhaps none were drawn except ephemeral ones scratched out in the sand. Any written instructions would be of little use to a largely illiterate population, and so the best ploy would be to learn the names of a string of destinations by heart, and to enquire locally the way to the next on the list. A traveller would be reassured that he was on the right route when he saw familiar landmarks, some of them with names already discussed, such as the crossing places and the places offering sustenance. In other places without such markers, a distinctively shaped hill might suffice. Hills make useful landmarks as they can be seen from a greater distance than features such as waterways or hollows. The kinds of places where a traveller might be most glad of a guiding landmark is less likely to be on a long stretch of well-used trackway than where that trackway branched and he had to make a choice of route, or where he wished for confirmation that he was approaching his destination. Improbable as it may seem at first sight, there was a term, or $r$, applied to distinctively shaped hills, and later to the settlements beside them, that fulfilled this need for a signpost; to a lesser extent yfre and ofer had this function too. The reasoning behind this suggestion follows.

There has been some uncertainty as to the meaning and origin of öra. Smith ${ }^{1}$ described it as 'river bank, shore, foreshore, the brink or edge of a hill, a slope' and Ekwall ${ }^{2}$ as 'border, margin, river bank, shore', and 'firm foreshore or gravelly landing place' in Hampshire names. Gelling ${ }^{3}$ enlarged on these definitions, describing examples. These definitions of $\bar{o} r a$ closely parallel its use in the pre-Conquest Latin prose of Bede and Aldhelm, where it was used to describe the edges of garments, rivers and seas. Toller gave two examples of its use in OE, one glossing its use in a psalter written in Latin regarding the edge of a garment, the other in an $O E$ poem where it referred to the edge of a slope. ${ }^{4}$ In neither case did the definitions result from a close study of its use in place-names. However, work since the 1980s has shown that the Anglo-Saxon topographical vocabulary was large enough for various sizes and shapes of landforms each to be precisely named; a whale-back shaped hill was a dün, a rounded hill a beorg, a steep slope a clif: why, therefore, should ora be applied to three rather different features - a hill slope, a riverbank, a sea shore? Surely there must have been some landform common to all these óra sites, so that an óra could be as precisely defined as other topographical elements. With this in mind I investigated all the oras and came to the conclusion that óra represented a flat-topped hill with a rounded shoulder at one or both ends. ${ }^{5}$ This has been accepted by Watts ${ }^{6}$ but only partially by Mills. ${ }^{7}$ The hill is sometimes an isolated

\footnotetext{
${ }^{1}$ Smith, Elements, 2, p. 55

${ }^{2}$ DEPN, s.n. öra.

${ }^{3}$ Gelling, Place-Names, pp. 179-82

${ }^{4}$ R.E.Latham and others, Dictionary of Medieval Latin from British Sources (London, 1975, ongoing), p. 2042; An Anglo-Saxon Dictionary, ed. T. Northcote Toller (Oxford, 1898), p. 763, s.n. ora

5 Ann Cole, 'The Meaning of the OE Place-Name Element Óra', JEPNS, 21 (1989), pp. 15-22.

${ }^{6}$ CDEPN, p. xlvii.
} 
feature, but is often a spur projecting from a longer range of hills, as is the case with Chinnor and Lewknor OXF. The nature of an ora means that to appreciate its shape it has to be seen from a distance, and usually has the öra-named settlement between the viewer and the or $r$. If it is a spur from a larger range of hills the óra profile can be seen from either side, but usually not from head-on, nor from the point where it joins the main hill. It is important to know from which directions the characteristic flat top and rounded shoulder can be seen. This definition can be seen to apply with little difficulty to the old 'hill-slope' óras. How well does it apply to other categories? The old 'river bank' oras such as Pershore WOR, or Boxford and Bagnor BRK, all have flat-topped hills with rounded shoulders behind them. The definition 'river bank' is redundant (see lists on figs 8.1 and 8.2, and map: fig. 8.4. For details of each example see Appendix part 3$)^{8}$

The suggestion that the coastal oras, particularly those in the Portsmouth area, also refer to flat-topped hills with a rounded shoulder has raised a few objections. The oras on the north coast of Kent are small but appropriately shaped hills, those of East Sussex somewhat larger; the three in Poole Harbour, Ower, Goathorn and Fitzworth, are backed by the classically shaped ōra of the Purbeck Hills between Corfe Castle and Swanage, and the numerous oras on the lowland between Portsmouth and Bognor are backed either by Portsdown or by part of the South Downs. Objectors say that these hills are too distant (up to 8 miles) to be a landform dominant enough for a settlement to be named from it, and further, that some of the qualifying elements like rüh ('rough') in Rowner and sage ('swampy') in Sinah refer to features at the site of the settlement, not to those on some distant hill, ${ }^{9}$ while Mills interprets the ora in Bognor as 'shore'. It is, however, possible to see Portsdown and the South Downs from offshore. They are shown in sketches in the Channel Pilot as important landmarks for sailors. ${ }^{10}$ In view of the way that $\bar{r}$ ra may have come into the language this is a very important factor, and could account for the numerous ora-named settlements on the low-lying land between Portsdown and the western South Downs, and the sea.

The distribution of the coastal öras especially in south-east England, is intriguing and requires explanation (fig. 8.3). ${ }^{11}$ Starting from the Thames estuary and working clockwise round the coast, the öras are Bignores by the Darent at Dartford; Upnor on the Medway just sea-wards of Rochester; Oare beside the creek approaching Faversham; Ore Farm at the western entrance to the Wantsum Channel near Reculver, and Stonar at the south-eastern entrance near Richborough. Further round the coast, Argrove is near Lympne (Roman Portus Lemanis) and Hythe (see vol.2, pp. 219-20 and on). Considerable coastal changes have happened in the Dungeness/Romney Marsh area, but in former times there was ready access to the river Rother and the Isle of Oxney, and here Kitchenour is to be found. Ore overlooked the old port at Hastings. Two lost ôras, Cudnor and Bestnover, were adjacent to Pevensey (in both cases their spellings were confused with ofer which has much the same meaning - see below). There is a lost Greynor near Eastbourne, a lost Sandor in Seaford (a High and Over (ofer) a short way up the Cuckmere), and Nore Down a short way up the Ouse. Nore in Sompting is a spur near the coast a couple of miles west of Portslade and the busy Adur estuary. The Cuckmere, Ouse, Adur, and Arun were once open estuaries leading inland through the line of

\footnotetext{
${ }^{7}$ Mills, p. 526, and s.n. Bognor, Lewknor and Pershore.

${ }^{8}$ An exception has been made with orra and ofer in that charter boundary examples have been listed. Where the boundary has been solved and the hill ridges identified the grid references have been given too. Several are prominent features of the landscape and easily recognised from a long distance, and therefore useful to travellers, e.g sceobban oran BRK and wat oran HMP. Ofer is rare in charter boundaries.

${ }^{9}$ John Pile, 'Ora place-names in the Portsmouth area' Hampshire Field Club and Archaeological Society, 33 (spring 2000), pp. 3-7, and other people in discussion.

${ }_{10}$ Channel Pilot, vol. 1 (Admiralty Hydrographic Department, London, 1957), facing pp. $261,262$.

${ }^{11}$ Ann Cole, "The Origin, Distribution and use of the Place-name element Ora and its Relationship to the Element Ofer', JEPNS, 22 (1990), pp. 26-41.
} 
the South Downs and were valuable, sheltered havens. Further west the next ora is Bognor, quickly followed by the cluster between Chichester, Portsmouth and Southampton, which take their names from the South Downs and Portsdown. Thus far the oras appear to be paired up with havens. Indeed, the only old port apparently without an adjacent ora is Dover, while the only ora near the south coast and not close to a haven is The Nore in Sompting. The long stretches of coast between Brighton and Portslade, and between South Lancing and Bognor have neither havens nor ōras. This indicates that there is a strong correlation between havens and $\bar{r}$ ras, the latter usually being situated seawards of the port. Most of the ports or havens listed above are known to have been used during the Roman period, and their Latin names are known to us. In some cases part of the Latin name or a Latin word has been incorporated into the Old English one, for example, Faversham incorporates Latin faber 'a smith', Reculver comes from Regulbium, Richborough from Rutupiae, Lympne from Portus Lemanis, while Portslade and Portsmouth incorporate Latin portus. The remains of the Roman buildings would have been visible, and the havens and ports well-known to Saxon pirates and subsequent invaders.

It could be asked if the same association occurs west of Portsmouth. Ower and Calshot HMP, are at the entrance to Southampton Water which gave access to Hamwic; Needs Oar Point, at the mouth of the Beaulieu River, was slightly west of the small Roman port of Lepe with Stansore Point a little to the east; Bure Homage was near the harbour behind Hengistbury Head; Ower, Fitzworth and Goathorn were near the little Roman port at Ower on the south side of Poole Harbour. There are three possible óras on the Isle of Portland, but there are only nineteenth century spellings for them. Toppesoran is on the Exe estuary on the approach to Topsham (a Roman port) and Exeter. There are no further öras along the south coast nor along the north coast of Cornwall. They reappear when Barnstaple Bay is reached - the joint estuary of the Taw and Torridge - at Chivenor and Yarner Wood. A long stretch of dangerous, harbourless, óra-less coast follows until the bay at Porlock is reached and the headlands at Kitnor (now Culbone) and Yearnor appear. No further öras are known until the mouth of the Avon is reached near Bristol, where Capenore is adjacent to Portishead and overlooks the erstwhile haven. Thus, this coast, too, from Southampton Water round to Bristol has óras associated with havens, and it is noteworthy that three of the four examples of port from Latin portus there are accompanied by oras; Portland, Porlock and Portishead. Portlemouth, if it is an example of port, is not. Incidentally, the two more easterly examples of port, Portsmouth and Portslade, are also marked by ōras.

There are various inlets that might have been used as havens which do not have orras nearby: Bridport, Axmouth and Portlemouth on the south coast, Combwich at the mouth of the Parrett, and Uphill at the mouth of the Axe on the Severn estuary are possible examples. On the other hand, there are no coastal oras which are not associated with a haven. The correlation between oras and havens is still evident. Given that this is so, what did the oras signify, and how did these features come to be called ora and not by some other term?

It would be tedious to describe each of these oras - details will be found in vol. 2, pp. 219 onwards, but to summarise, with the exception of Stonar KNT, Stanover Lane SSX, Stansore Point HMP, and Stonner Point SFK, which refer to shingle spits, they are all hills with the characteristic flat top and rounded shoulder, they are mostly seawards of a haven, often near the mouth of an estuary, and they are all visible from the sea. For any ship's crew the first view of land would not be the shore but any hills near the coast. On recognising the hill and then the coastal profile adjacent, the helmsman would know where to steer for the desired port, just as is shown on the coastal profiles in the Channel Pilot for today's sailors. If $\overline{o r a}$ was a term used for something other than a sailors' landmark signifying the approach to a port, there would surely be examples of them along stretches of the coast where havens were absent. This does not seem to be so. It was noted earlier (p. 94) that in OE writings it was used in the same sense 
'edge, margin' as it was in the Latin of Bede and Aldhelm. In Latin one of its senses was 'shore'. This, combined with the close association with places incorporating port, a Latin loan word, in their names and with Roman ports, prompted Margaret Gelling in the course of conversation, to suggest that $\bar{r} r a$ was also a Latin loan word. A possible scenario for this borrowing was that it happened aboard ship. When the coast came in sight - not the shore but the hills rising behind it - the lookout would cry 'ora!' 'land ahoy!' Germanic crew members on Roman ships with Latin speakers in charge would come to associate the hills with the term 'ora'. Its appearance in ASC to describe the landing places of the early Saxons supports the idea that $\bar{r} r$ was in use in the earliest years of the Anglo-Saxon period. The landing places in question were Cerdices öra (ASC 495E, 514E and 514A) and Cymenes öra (The Owers, ASC 477A and 477E). See vol.2, pp.220-2. This may explain the use and origin of the term ora as used around the south and south-west coasts. It is difficult to think of any other explanation that fits the observations. The next point to consider is the inland distribution of ora and how its use might have been transferred from that of a sailor's landmark to a 'signpost' for an inland, overland traveller.

The inland distribution is shown on figs 8.3 and 8.4. Öra is found in southern England. Its counterpart ofer is found in the midlands and north of England: in essence ora occurs in the territory occupied by the Saxons and ofer in the territory occupied by the Angles. Some overlap occurs in the borderlands between the two: Pershore WOR, and Bradnor HRE, are the most northerly examples of ora, in amongst the ofers, and Shotover OXF, is an ofer on the northern fringes of ora country.

If the term ōra was first used of sailors' landmarks around the south-east coast it would not be surprising to find the inland examples in its hinterland. Early Saxons with the word in their vocabulary having learnt it from seafarers, would explore the coastlands and follow existing tracks inland. They would use the term to describe landforms in a way they felt was appropriate along with many other terms for hills, valleys, streams and settlements. Does the distribution hint at what was felt appropriate? The map of South-East England, fig. 8.3, shows that east of M 15 (London - Chichester) some of the Roman roads have a series of óra names close by (as ōras can be quite large hills, the feature does not have to be as close to a route as something like a mere or a strät-tūn does, in order to be seen and be of use to a traveller). The Roman road from Chichester to Pevensey along the scarp-foot of the South Downs has a series of öras by it, so does Stane Street, M 15. The southern parts of M 150 and M 13 have one each. The Pilgrims Way has a series along it where it is crossed by Roman roads. The spaces between the roads - between M 15 and M 150, between $M 150$ and M 14, between M 14 and M13 (except Vexour and Ashour on the Medway, (see vol.2, pp. 224) and much of the area between M13 and M12 are devoid of óras. Unexpectedly, M 1 is devoid of ōras too. West of M 15, Chichester - London, the situation is more confused - there are still oras by Roman roads, M 42 and M 155 for instance, and a good series along the Icknield Way from Chalk Wood OXF (Chelcoran) to Aldbury Nowers HRT. However, there are large numbers which are not beside any of the routes shown on the O.S. Map of Roman Britain. This does not mean that these oras are not by old routes. Much of the area west of M 15 is chalk downland. It is easy terrain to travel over and so there were plenty of trackways in addition to the Roman road system. This contrasts with the difficult conditions in the Weald where the Roman roads were much the easiest routes to use. Therefore, in the downland, oras can be found beside lesser Roman roads like Old Street BRK (Woolvers, Oare, Boxford, Bagnor); well-used ridgeways like the North Hampshire Ridgeway (Watoran, Middeloran); a herepath heading for London (Bugmore), and Knightsbridge Lane OXF (Clare, Golder, Readanoran, Stonor): in fact the majority of oras are by important routeways of some sort. The chief exceptions are in the Chilterns where there are three such groups: Pinner and Nower; Ballinger and Pednor; Courns Wood, Denner Hill and Honor End. The most prominent man-made features in the landscape 
common to all three groups are linear earthworks all called Grim's Ditch. Bixmoor OXF, is also by a Grim's Ditch as well as by the Icknield Way. In Wiltshire, Oare and Martinsell are not far from an extensive earthwork called Wansdyke which runs along the scarp crest, apparently defending the people to the north from attack by people from the south in the fifth or sixth centuries. ${ }^{12}$ Oare and Martinsell would be useful landmarks for the north-bound traveller at any time, but may once have warned of the approach to a boundary with an antagonistic group, and one would need to be careful in such situations. The cluster between M 42 and M. 155 refers to the dramatic chalk escarpment at the western end of the Wealden pericline (see vol.2, pp. 228), it is associated with the road between Petersfield and Oxford. Otherwise the spaces between the major routeways are generally devoid of oras - the zone between the Harroway and M163 has only the isolated Stanners Hill in it.

The majority of inland oras are, then, beside routeways; their shape the same as that of the coastal ones. If the coastal $\bar{o} r a$ s signify the presence of a haven and a landing place to sailors, what do the inland oras signify to the overland travellers? Because they are generally by routes and not elsewhere, they are likely to signify something connected with road travel, and probably act as a warning that a place of importance/significance to the traveller is close by. A traveller without maps or signposts would need to be alert for road junctions to avoid taking wrong turnings or not to miss the turning onto a road that he wished to follow. It is clear that some öras, especially those associated with the Pilgrims Way and the Roman roads which cross it (M 14 and M 15), could serve that purpose. A second feature that a traveller might be glad to have warning of is a river crossing - Hedsor BUC, and Oreham SSX, could serve that purpose.

For incoming Saxons, familiar with the use of ora for a coastal feature, it could seem appropriate to use the same term for a similarly shaped inland feature important to them as they penetrated inland from the south-east coast. Much would depend if the local topography contained hills of the appropriate shape to be called 'ora'. If it was important to have a 'signpost' at a particular junction then one might have to make do with a less than perfectly shaped hill e.g. The Nower near Dorking. There are numerous flat-topped hills with a rounded shoulder of a typical ora shape which do not bear öra names. Some are found in the countryside between the Roman roads, and others are ideally situated near to them. The hill on the eastern side of M 41/M 43 the Cirencester - Swindon - Mildenhall road as it approaches the Berkshire Downs and enters the Ogbourne valley is ideally shaped and situated for an ora and yet is not called 'óra' but Liddington Hill. Although one could postulate that it once had an ora name which has since been lost, such a circumstance is not likely to account for more than a very few of the óra-shaped hills without $\bar{r}$ r names which are in appropriate situations.

If oras warn of significant points on important routes what sort of places were those routes leading to (or coming from)? Many of the routes have come from ports and are heading towards centres such as London. Others occur in places which might have been important in Saxon eyes for their resources: iron and salt are two examples. The only öra on M 13 which runs through the Weald is at Great Courns which was close to a Roman iron working site. One of the pair of oras by M 14, Tugmore, was the site of Roman iron ore mines: the other, Hodore, nearby is beside the Medway, while the only two non-roadside oras in the Weald, Ashour and Vexour, are a little further down that river. Do these four oras collectively (supported by the information about Great Courns) suggest a Saxon re-use of the Roman iron ore workings and the transport of iron down the Medway? If not, why are there öra-named hills in those localities? What else could they have signified? Consider the Chiltern oras beside the Grim's Ditches. The ditches are thought to have separated arable land from cattle pasture. The Saxons were known cattle raiders. Did these oras guide the rustlers to the cattle? If not why are they

${ }^{12}$ Barrie Cunliffe, Wessex to A.D. 1000 (London, 1993), pp. 294-6. 
there? They are not by any known important routes, road junctions or crossings, they are not near important centres, royal residences or defended sites, there are no mineral resources there, so what else might have attracted the Saxons to these extensive woods and wood-pastures? The possible raison d'etre of the individual öras are discussed in vol. 2 as are the ofers. Sometimes one cannot be sure why an ora is at a particular place on a particular road. It does not seem to be their function to say 'this is the flat-topped hill with a rounded shoulder on the road leading to the port....the river crossing.... the iron mines'. Their function seems simply to reassure a traveller that he is on the right road, to look out for junctions and crossings, and to warn of imminent arrival at a destination whatever that may be. To that end $\bar{r} r a$ is quite often qualified by tree names - evergreen box, tall elms or ashes, or by names of large birds, cranes or herons, kites or eagles - which would help the traveller pick out the hill from a distance $(12 \%$ of qualifiers): it is also often qualified by a term describing the surface of the ora - stony, sandy, red $(12 \%)$ : it is often a simplex term $(16 \%)$ or combined with a personal name $(21 \%)$. There are no known examples of öra qualifying the name of possible destinations; no ceaster-ōras, port-öras, gedelf-öras. Only in Orford SFK, is ora combined with ford and this is an atypical case as $\overline{o r a}$ is the qualifier (which it is only rarely) and the ford is not a crossing but a raised causeway (see vol. 2, p.218). Without the clues that names like *port-öra would have provided, it is a matter of choosing the most likely place of interest that the ora is indicating the way to. As the case of the Chilterns shows, many types of destination can be ruled out for each example, leaving possibilities that are debateable. Take Orford and Stonner Point on the East Anglian coast: they are the only coastal oras north of the Thames, implying that there was something of particular interest locally to the Anglo-Saxons. Stonner Point on the Deben is in the wrong estuary to indicate the way to the trading centre at Ipswich: there are no significant mineral resources nearby, but there was the highly important seventh century burial ground of the East Anglian kings at Sutton Hoo beside the Deben. Orford on the Alde a little further north, gives less ready access to Sutton Hoo, but would be a convenient point for the seafaring traveller to land in order to visit Rendlesham, which was a royal centre, albeit only for a short time in the seventh century. One has to assess whether there are any other more likely destinations in the area: whether it is just by chance that Orford and Stonner Point are at this point on the coast, or is the explanation offered above the most likely one?

All the oras are listed and discussed in vol. 2, pp. 219 onwards, and they are treated regionally instead of county by county in an effort to show how they relate to the routes in each area. The map (fig. 8.4) shows that ora is a southern term found basically in Saxon territory but gives way to ofer, its counterpart, in Anglian territory, but the division is not hard and fast: ${ }^{13}$ Shotover near Oxford has spellings suggesting derivation from both ōra and ofer; Batsford GLO, is an orra in Hwiccean territory, as is Pershore WOR. The generic in Bradnor HRE, uncertain according to Ekwall and Coplestone-Crow, is probably öra. The presence of these oras amid the ofers of the midlands and north has been attributed to the presence of the Hwicce, an Anglian group with possibly some Saxon admixture living in Gloucestershire, Worcestershire and western Warwickshire. Some traces of the West Saxon dialect have been noted by Smith in Gloucestershire and it is possible that the use of ora derives from some West Saxon penetration of the area. ${ }^{14}$ Mostly the Hwicce used the Anglian term ofer, but ora is used of two places, Batsford and Pershore, in their territory, and perhaps of Bradnor way beyond it on the Welsh border. A different explanation for these anomalous names from that of the survival of some West Saxon dialect terms in the south-west midlands, might be considered as they are on a route that Ogilby describes from London to Aberystwyth (now the A 44 for most of its length west of Oxford). ${ }^{15}$ It runs past Lewknor (óra), Shotover (ōra/ofer), Batsford (öra),

\footnotetext{
${ }^{13}$ An ofer has the same shape as an ora, see below p. $189 \mathrm{ff}$.

${ }^{14}$ Gelling, Place-Names, p. 179; PN. GLO, 4, pp. 33-4.

${ }^{15}$ Most of this route is shown on fig. 9.5
} 
Pershore (öra) and Worcester, where it passed Red Hill (ofer); the lost Mapnors (ofer) may have been visible as it passed Knightwick. Approaching M 613 it passed Hennor (ofer); beyond Leominster the pass into the Cambrian Mountains was marked by the large Bradnor Hill (öra or?ofer). Thereafter, the road went by Old Radnor (ofer) and so to Aberystwyth Spellings suggest that Batsford, Pershore and Bradnor are oras in ofer territory, and that Shotover is an ofer in öra territory. Travellers from southern England using this route towards Aberystwyth, might prefer to call the major 'signpost' names on their route by the term that they were familiar with - and so one substantial group of people would know Shotover and Bradnor as óras. Meanwhile, those from the Welsh Borders going London-wards might prefer to adhere to their familiar term ofer, and regard Shotover (and Bradnor?) as ofers; this might account for their variable spellings. The minor 'signposts' on this route, such as Mapnors and Hennor, retained the local term in their names. It could be that the term ora was infiltrated into Hwiccean territory by travellers from southern England following the line of the LondonAberystwyth route, rather than being an effect of the mixing of ora and ofer in a zone where two dialects meet.

Other ofers occur deep within ōra territory. They are almost all 'directional ofers'; that is, they are Northovers, Southovers, Westovers and *Eastovers, (see map: fig. 8.4 and list: fig. 8.6). These characteristic name forms - 'direction + ofer' - and their distribution, all lying by rising ground adjacent to rivers, suggests a particular and different usage from other ofers. In some cases directional ofers occur where a routeway crosses a river. Langport Estover and Langport Westover SOM, are on the banks of the Parrett where it is crossed by Old Way; Stour Estouere and Stour Westoure DOR, are where a Gough route crossed the Stour; Bridgwater Estover and Bridgwater Westover SOM, are beside the river Parrett which was bridged here by 1086 , implying that there was an important crossing. Southover DOR is on the south bank of the Piddle close to the M 4e crossing; Northover is where M 5b crosses the Yeo at Ilchester (fig. 9.6)

Other directional ofers occur where there is a landing-place: Northover on the Brue for the marsh-girt Glastonbury, Southover for Wells, and Westover by the Parrett where travellers from Muchelney or the higher reaches of the Parrett accessed the Curry peninsula - a Drayton helpfully nearby. Further east, Southover indicated a landing-place for Lewes; Bestnover and Southover for Pevensey SSX.

Other directional ofers do not fit the picture so well. Westover HMP, by the Salisbury Avon, is not evidenced until 1638, while Southover in Frampton DOR, close to the Roman road, $M$ 47 , crossing of the Frome is not evidenced until 1670. In two cases evidenced before 1500 , the streams look too small to be navigable, but there are possible Roman roads nearby: Westover in Wootton Fitzpaine, and Yondover DOR. Although Westover IOW could be said to be on the west bank of the Calbourne burna it is too small a stream for boats, while Westover HMP, by the Anton, is distant from a Roman road. Eastnor HRE, is probably not to be included in this southern group, in spite of its name.

None of these settlements with directional ofer names is recorded before the twelfth century, and they are not a uniform group, but it does appear that some indicate a meeting of water and land routes, and thus an opportunity for trans-shipment and perhaps a little trading, especially in the cases of Langport, Bridgwater and East and West Stour.

Ofer was a term used by Anglian peoples, generally north of the Thames and particularly in the West Midlands, Welsh Marches and Peak District. It is not known in East Anglia; it is rare in all of eastern England and only occurs sporadically in northern counties (see list: fig. 8.7, and map: fig. 8.4). It refers to a flat-topped ridge, a definition used by Gelling in 1984. When the shape of an ora was identified it was realised that öra and ofer referred to the same shaped landform, but that their distributions were largely complimentary. In her discussion of ofer 
Gelling ${ }^{16}$ points out that there is a term ofer meaning riverbank which is difficult to distinguish from ofer. However as most riverside examples are associated with appropriately shaped hills it is unlikely that ofer was widely used. Given that ora and ofer refer to the same shaped landform, the question next arises as to whether or not they shared the same function - as travellers' signposts.

Like ora, ofer is nearly always the generic in place-names except for three examples in Cheshire and one in Northumberland, and such of the Ortons and Overtons as may incorporate ofer. When the qualifiers of ofer are analysed the results are similar to those of ora: approximately $21 \%$ are simplex; $21 \%$ are combined with a personal name; $17 \%$ are combined with the name of a tree species or a term for woodland or occasionally a large bird. The appearance and shape of the ofer is commented on in $15 \%$ of names, with more examples of 'high' but fewer of 'broad' or 'stone'. Like öra, ofer is rarely combined with any term describing a habitation (once with 'church' recorded in 1345), nor does it combine with any term describing a possible destination - a port-, market- or settlement- name, nor with a routeway term - a ford or weg. The two terms are similar to each other in respect of the generics they qualify.

Is the detailed distribution of fer such that it could act as a 'signpost' as öra does? There is certainly a good correlation with roads in some places (see maps: fig. 8.4, and figs 9.1 - 9.6). In the west midlands (fig. 9.5) a series of ofers occurs on the salt ways radiating from Droitwich. Salt traders would have found M 56, the road from Droitwich to Stratford on Avon, particularly well signposted with Pridzor, Hadzor, Becknor, Noah's Green and Oversley beside it. Other salt ways going south-east pass Pershore (óra), Haselor (west of Evesham, ofer) and, as they pass into öra country, Daganoran and Batsford. Other well-marked routes are the $\mathrm{M}$. 541 leading from Gloucester to Bath passing Buckover and Over, and the route along the Welsh Marches from Hereford to Wroxeter (M 6) which passes Adzor, Chadnor and Hazler (see vol. 2, pp. 232-3).

Ofer also marks crossing places; Ashford Mill OXF, the crossing of Akeman Street over the Evenlode, and Wychnor STF, the crossing of M 18 over the Trent.

Only one, Preesall LNC, seems to indicate the approach to a haven, that in the Wyre estuary in Lancashire.

One ofer calls attention to a mineral deposit in its name, spceren 'plaster' in Spernall WAR, where gypsum is found. As gypsum is soluble it would rarely be visible on the ground surface, so speren is not likely to be used to describe the appearance of the ofer, but the useful mineral it has to offer. ${ }^{17}$ As ofer is associated with both salt and gypsum could it be associated with other mineral deposits too? There is a distinct cluster of ofers in the eastern part of the Peak District: Edensor, Calver, Ashover, Seanor, Cobnar and Birchover (see fig. 9.4). The limestone of the Peak District provided a firm base for trackways, but it was high in places and dangerously exposed in bad weather. There were many steep slopes and deep valleys, and so why were there so many ofers there? They were not connected with the Roman roads radiating from Buxton. Those ofers on the eastern flanks of the area (Cobnar, Codnor and Heanor) were fairly near the Derby to Chesterfield road (M 18b) but it is doubtful if they were visible from it. Three are well away from any Roman road - Calver, Edensor and Birchover - however, these were in the midst of a lead-mining district. The Romans had mined lead there. Ingots have been found near Matlock. ${ }^{18}$ Domesday Book records lead works (plumbariae), one each at Ashford, Bakewell, Crich and Shuckstonefield, Matlock Bridge and three at Wirksworth. The three royal manors of Bakewell, Ashford and Hope together had to provide five cartloads each

\footnotetext{
${ }^{16}$ Gelling and Cole, Landscape, pp. 199-200.

${ }^{17}$ R.A. Old, R.J.O. Hamblin, K. Ambrose and G. Warrington, The Geology of the Country around Redditch, (HMSO, London, 1991), p. 58

${ }^{18}$ K.C. Edwards, The Peak District (London, 1962), pp. 171-3
} 
containing fifty slabs of lead in $1066 .{ }^{19}$ There was certainly a market for lead: DB mentions lead vats at Bromsgrove, Northwick and Tibberton, Fladbury and Martin Hussingtree, presumably connected with the salt production at Droitwich. ${ }^{20}$ The lead or lead ore had to be transported out of the Peak District, perhaps down the Derwent or more likely along the old non-Roman tracks crossing the Peak. The three ofers, Calver, Edensor and Birchover, could well be associated with this traffic. A.E. and E.M. Dodds describe many such likely routes, but it needs someone who knows the area intimately to work out the relationships.

Another area where the Romans are known to have mined lead is in Shropshire near Shelve on the Stiperstones, and probably at other sites too, but subsequent mining has destroyed the evidence. Ingots have been found at Snailbeach (2?), Bishops Castle (1), Snead (2), and Roman buildings of unknown purpose have been found at Linley. There is a series of ofers west of the Roman road, M 6, as it passes through Church Stretton, namely Novers Hill, Overs, Upper and Lower Gravenor and Wentnor. Overs is where one track leads off west to Shelve and another leads south and then west past Upper and Lower Gravenor and Wentnor indicating the way to Linley and the southern approaches to the lead mining area (to continue south would lead to the marshland between More and Hardwick). Again the question must be asked was there anything else that would have attracted the Anglo-Saxons to the area? The Portway over the Long Mynd, an $\bar{e} a-t \bar{u} n$ on the river Onny, Stank Lane running from Craven Arms to Bishop's Castle and on into Wales to Newtown suggests a lot of movement, but all this is several miles south of Wentnor and the other ofers.

Mention has been made of some Herefordshire ofers on the Ogilby route (the A 44) in the Welsh Marches. The Roman road running from Hereford or Kenchester along the Welsh borders to Wroxeter, M 6, is well served by ofers used as landmarks en route (map: fig. 9.5): Adzor at the junction of the Roman roads from Hereford and Kenchester; Chadnor, and then a cluster in the Church Stretton valley marking side-roads. In Yorkshire, particularly along the approaches to York from the west or maybe to the main road north, M 28/M 280/ M 8, the ofers are usefully placed for travellers (see map: fig. 9.4).

There remain two ofers in Northumbria well to the north of any other examples. Both are by roads, but just why those stretches of roads should have been marked by ofers when nowhere else nearby is needs explaining. Overgrass (Oversgare) lies between two important roads running south to north. One is the Roman road, M 87, known as the Devil's Causeway, linking Corbridge to Berwick-on-Tweed, the other is the Great North Road south of Alnwick. They are quite close to each other here and a suitable point to cross from one to the other (cf.

Hunsingore YOW, which may have the same function, vol. 2, pp. 237). Alternatively, it could signify their approaches to the crossing of the Coquet. Wooler is discussed in vol. 2, p. 238 where it is suggested that it marks the point at which to leave M 87 and bear west to reach the old Northumbrian royal centres of Gefrin and Melmin which flourished in the seventh century Again the question arises is there anything else in the neighbourhood of Wooler that made it worth using a term rare in the north, and elsewhere is used to signify a place of importance? It is not coastal, it is not a junction of Roman roads, it is near a crossing of the river Till, perhaps a muddy one as East and West Horton (horh 'muddy') are nearby, but the crossing of a small river is a common enough occurrence on many routes. What distinguished this neighbourhood was the presence of the old royal centres of Gefrin (Yeavering) and Melmin (Milfield) floreat $605-685$ to the west of M 87 about 6 miles as the crow flies, and the royal stronghold of Bamburgh some 10 miles to the east. Coming from northern Northumbria along M 87 Wooler's ofer would indicate a branch road leading west to Gefrin and Melmin, or a branch leading east to Belford and thence to Bamburgh. Given the choice, using the Great North Road

\footnotetext{
${ }^{19}$ H.C. Darby and I.S. Maxwell, The Domesday Geography of Northern England (Cambridge, 1962), pp. 323-4.

${ }^{20}$ H.C. Darby and L.B. Terrett, The Domesday Geography of Midland England (Cambridge, 1954), p. 256.
} 
would make a more efficient route to Bamburgh from both north and south since it passes through Belford. In fact the raison d'etre of Overgrass might have been to show the northbound traveller coming along Roman roads from Corbridge where to transfer to the Great North Road.

The northerly approach to Tamworth, a royal centre of the Mercians, is marked by Wychnor which not only marks the crossing of M $18 \mathrm{c}$ over the Trent but also a turning east along an old salt traders route which crosses the Tame, passes Haselour and approaches Tamworth along the Portway. Together with Orford and Stonner Point in Suffolk there are three royal centres whose approaches appear to be marked by oras or ofers. They were flourishing in the seventh century although Tamworth remained an important centre long after the decline of Yeavering and Rendlesham.

There remains a hard core of ofers for which no links to major routeways have been found. They mostly lie in Cheshire, Staffordshire and Derbyshire (see figs. 9.4 and 9.5). As Margary notes, the Roman roads of Cheshire and Staffordshire are 'ill-known', ${ }^{21}$ all trace of some ends in the middle of nowhere. It is possible that some of these ofers were by now long-lost Roman roads or other old routes. Although the Gough route from London to Lancaster takes in Tittensor, and Hereward's Street is perhaps connected with Okeover, I know of no routes for Badger and Ramshorn, while that at Radnor appears to be a summer-time only crossing of the Dane. To the east of M 18d from Littlechester to Chesterfield are Heanor, Codnor and Seanor Farm: they are a little too far from M $18 \mathrm{~d}$ to be useful, while the Ogilby route through Bolsover is too far east to relate to them, so they, too, are hard to explain at present. It is evident that although in most areas (around Droitwich, the Welsh Marches, the East Midlands and the North) ofer makes a useful signpost on route-ways, this is apparently not so in parts of Cheshire, Staffordshire and Derbyshire, but it is hard to be certain whether this is due to lack of knowledge of the old routes of the area or whether it is because ofer was not regularly used in the same way as $\overline{o r a}$; on the whole, as ofer is used by routeways and to indicate similar resources, it is more likely than not that it is used the same way, and one should be alert for routes near all the ofers.

There is a derivative of ofer, yfre, which is used in the more southern counties east of WLT (see list: fig.8.8 and map: fig. 8.4). They are a varied group: just over half refer to settlements. Only three are close by rivers, unlike the directional ofers; seven refer to steep scarp-slopes with important ridge-ways running along their crests. This, like the case of $\bar{e} w i e l l$ and $\bar{e} w i e l m$, may be an accident of geology in that escarpments have appropriately-shaped slopes while their crests make ideal route-ways. Only two are associated with Roman roads: Bignor, and River's Farm in Ardingley SSX. Only five are both settlements and associated with routeways, they cannot be said as a group to be reliable indicators of important routes in use. In the area in which yfre occurs ōra fulfils that function, probably because it was a term in use from the earliest times, and the significant points on route-ways already had öra names when $y$ fre made its appearance.

There are two other recurring names that may contain ofer: Overton and Orton (see list: fig. 8.8 and map: fig. 8.4). Unless there are early spellings it is not possible to distinguish between uferra-tün, 'higher settlement' and ofer-tün, 'ridge settlement'. All the possible examples are in areas where ofer was in use. Many of them are on/by ofer-shaped hills close to Roman roads ( 7 examples) or routes described in Ogilby ( 2 examples); five are close to rivers and more useful to boatmen than overland travellers: two are better regarded as uferra-tüns as judged by their positions with regard to their relief and routeways. Clearly those Ortons and Overtons which are apparently ofer-tüns cannot be used to identify routes when they themselves have been distinguished from the uferra-tüns partly on their position with regard to routes, but it is none-

${ }^{21}$ Margary, Roman Roads, 2, p. 246. 
the-less pleasing when they occur on those old routeways which have other route-indicating names, such as the Buxton to Manchester road M $71 \mathrm{~b}$

In conclusion, the use of ōra as a 'signpost' for both sailors and overland travellers seems to date back to the early Anglo-Saxon period, and it signified important places such as ports, road junctions, mineral resources, linear earthworks and the burial mounds at Sutton Hoo and the one-time East Anglian royal palace at Rendlesham (floreat seventh century). It is important evidence for routes in use early on in the Anglo-Saxon period, not only the Roman roads, but also in helping to identify which of the many chalk downland tracks were considered useful through-routes.

The use of ofer is more complex. In the form 'element + ofer' or the simplex ofer it is frequent in the midlands and occasional in the north, serving a similar purpose to ora. In some cases in the south it was used as a 'signpost' for boatmen by referring to small riverside hills (which orra rarely was), almost always as a directional ofer (Northover, Southover etc), although occasionally hean-ofer occurs (High and Over SSX, Highover HRT, and there is a Yondover in DOR). The directional ofers do not extend beyond ora country. Yfre, a dialect form of ofer, is found in south-eastern England overlapping with ora. It seems to have come into use later than ōra; the most important 'signposts' already bore ōra names, and so yfre was used of less important features and only rarely signified important routes. Ofer in the midlands and north rarely occurs by ports, unlike o ra, but it was associated with mineral resources, occurring on the salt ways radiating from Droitwich and the Cheshire wiches, and in clusters in the lead-mining districts of Shropshire and the Peak District; the way to the seventh-century royal palaces of the Northumbrian kings at Gefrin and Melmin was indicated by Wooler, and that to the Mercian kings at Tamworth by Wychnor and Hazelour.

The ofer-tüns in the form of Overton and Orton are rarely distinguishable from uferra-tūn by their spellings, although their sites and situations with regard to routes may favour one or the other interpretation. Ofer is rare as a first element (as is ora), except for this comparatively frequent combination with tün.

These signpost elements would have played a very important role in helping early medieval travellers. They were important sea-marks enabling sailors to make a safe landfall in the haven of their choice, and they were important for overland travellers in way-finding. This would have been especially so in earlier days when the naming system along route-ways was in the early stages of development (see further in Chapter 10).

Having considered the roads, crossing places, facilities, signposts and place-names associated with water transport, the scene is set to see how these terms used in conjunction with one another can reveal a communications network in early medieval England. 


\section{CHAPTER 9}

\section{SYNTHESIS}

In earlier chapters place-name corpora have been identified which either describe important roads or crossing-places along them, or which, while not describing routes, consistently occur beside them. In this chapter all this information is put together to identify the routes in use. The information from chapter 6 , Water Transport, is also incorporated.

\section{THE MAP}

The resulting map (in the end pocket of volume 2) incorporates the major differences in the river systems of the Fens and Somerset Levels and in the coastline between the early medieval period and the present day, and shows the early medieval routeway network as deduced from the place-name evidence. Almost all the place-name elements discussed are shown, colour-coded according to the chapter they occur in, and each with a different symbol. The Roman roads and ancient tracks as shown on the O.S. Map of Roman Britain are shown as fine red lines (continuous or dashed). Other roads discussed in earlier chapters or in Section 3 of the Appendix are shown: additional Roman roads in red, salt ways in mustard yellow, Gough roads in mid-green, Ogilby roads in dark green, 'other roads' in magenta - all as fine lines.

Using this data, it was then possible to indicate, by thickening the lines of the roads, which ones the place-names evidenced by DB suggested were in use in the early medieval period (thickest lines); those for which the evidence was post-DB were shown by mid-thickness lines. The method is described below.

\section{COMPILING THE MAP}

\section{Overland transport}

A good day's journey was assumed to be 20 miles, as described in chapter 1 . Each place plotted on the map generated a stretch of road-in-use 20 miles long, that is, 10 miles either side of the place; thus, for two places 20 miles apart the stretches of road-in-use met one another at the halfway point between the two. This worked well on stretches of road with no junctions, but where there was a choice of route which one was the continuation of the roadin-use was not necessarily obvious. In these cases the stretch of road-in-use was terminated less than 10 miles from the place of origin. If one of the possible routes had indicative placenames along it but the other had not, then the first option was highlighted.

Using the map described above as a base, the early medieval routes with DB or earlier evidence, and the routes with only post-DB evidence were compiled by:

a) Plotting, as roads almost certainly in use, 10 miles either side of all the examples of strät-tūn, strōet-ford and 'strōet + element', together with the sträts (simplex) recorded in DB and earlier. This, almost by definition, highlights stretches of Roman road. They are distinguished on the map by being shown in grey.

b) Plotting, as supporting evidence, 10 miles either side of all the examples of geläd, gewoed, far, ritu, sarn, ferja, traiectus, selected brycgs (see chapter 4), most mere-tüns (see chapter 5), meres-on-chalk (see chapter 5), byden-welle, äwiell, äwielm, öra, ofer (excluding directional ofers), yfre, calde-cot, draeg-tūn, drag-cot, cumb-tūn and denu-tūn, using the appropriate thickness according to date.

c) The examples of funta, mōr-tūn, mersc-tūn, gräefe-tūn, wīc-häm, Orton and Overton, while not reliable indicators of roads-in-use on their own, can help to support other evidence; for instance, a DB mōr-tūn beside a route that otherwise has only post-DB evidence beside it 
could be taken as indicating a road-in-use in the early medieval period, and would therefore appear as a thick line.

d) Stretches of roads-in-use plotted as above sometimes end just short of a likely

destination - an important settlement such as London or Gloucester, or a port or wic such as

Hamwic. In such cases it is likely that the name of the destination itself was the last indicative place-name of the series, in which case the route is highlighted as 'presumed' rather than 'certain', and shown as a grey dotted line.

If a long route is indicated as being in use it is rare for any stretches of it to have no indicator name coverage. In other words indicative place-names are rarely more than 20 miles from each other, although they are frequently about 20 miles apart.

This process highlights many Roman roads-in-use. However, there are large numbers of indicative places which are beside non-Roman roads. Some of these are well-attested: the Droitwich and Cheshire salt-ways have been worked out using evidence such as records of salt rights recorded in DB, and place-names referring to salt and salters; the routes in Ogilby's 1675 Road Atlas which go through a series of place-names indicative of a road-inuse can be drawn very accurately as Ogilby gives good detail of all of his routes. Although Ogilby's routes were in use some 400 years after the Conquest, some of them go through places under consideration here; this implies that these routes were in existence and used centuries before Ogilby recorded them. The Matthew Paris map, thought to have been drawn about 1250 , shows a route from Dover to Newcastle through a series of named towns, but no details of the roads. The Gough map, drawn about 1360, shows many more routes with named towns along them, but is so lacking in detail that one cannot tell precisely which roads were used. However, some of Ogilby's routes go through precisely the same series of towns as the routes on the Paris and Gough maps do, suggesting that these routes of Ogilby's can be traced back to c. 1360 or in one case to c.1250; it is therefore likely that where these coincident routes have a series of significant place-names evidenced by the time of DB along them, they date back to the Anglo-Saxon period at least. Further, other non-Paris, nonGough, non-Ogilby routes with a series of significant names along them are also likely to be pre-Conquest.

There are other sources attempting to identify old routes. Many EPNS volumes have a section on road names: for instance, the Place-Names of Northamptonshire (p. 4) quotes a forest perambulation of 1228 describing the route taken by the Bedeford Weye (which runs close to a drag-tūn); The Place-Names of Rutlandshire (p. xx-xxi), describes two Roman roads, one identified from crop marks and the other from field and minor names; they tie in with Market Overton and Tixover, but are not on the O.S. Map of Roman Britain. In southern counties, where several adjacent charter boundaries use herepoth in their boundary clauses, it is possible to identify useful lengths of routes in use at the time (the Lunway for instance). These are particularly useful where there is an isolated indicative place-name and little else to indicate the route it refers to.

Many other authors have tried to identify old routes without using place-name evidence other than references to strēt, weg, herepath and sometimes ford. Some (for example Timperly and Brill $)^{1}$ have used relief maps to pick out ridgeways - largely by drawing in watersheds, but while a route along a watershed could be serviceable, the geography on its own does not demonstrate that such a route existed. Only in a few instances do the placenames considered here pick out such routes - the Salisbury Way for example. Other authors (for instance Eardley-Wilmot) ${ }^{2}$ have argued that routes link up prehistoric landscape features such as barrows, but, while such tracks may have existed and the barrows may have made

\footnotetext{
${ }^{1}$ H.W. Timperley and E. Brill, Ancient Trackways of Wessex (London, 1965).

${ }^{2}$ Hazel Eardley-Wilmot, Yesterday's Exmoor (Exeter, 1990).
} 
good landmarks on the route (rather as cairns mark mountain paths today), it does not mean that the routes, if they existed, continued in use in later periods unless people still wanted to travel that way. Yet others (for instance Grundy and Hooke) ${ }^{3}$ have used charter boundary features, especially references to strēt, weg, herepceth and pceth, to identify old routes, although many of these are only short stretches owing to the scattered distribution of estates with surviving charters. They are, however, more reliable, and some are supported by other place-name evidence - the oras around Halwell for instance.

Sherratt, ${ }^{4}$ writing about later British prehistory, wondered if the river names were significant. He cites the example of the Avons providing a partially navigable route from Hengistbury up the Salisbury Avon, down the Bristol Avon to the Severn estuary and then up the Warwickshire Avon to the heart of the midlands. While this might have been a route at one time there is no place-name evidence (except for the presence of Portishead at the mouth of the Bristol Avon) that these rivers were in use in the early medieval period: no hyths, no $\bar{e} a$-tūns, no directional ofers. Avons do, however, have large numbers of fords across them; it might be interesting to see whether this relates to some feature that their beds have in common making them particularly easy to ford or whether there are other reasons, but it does not suggest that they were extensively used for navigation. Bryony Coles ${ }^{5}$ suggested that the 'Trisantona' rivers (Trent, Tarrant) led to useful through-routes in prehistoric times, but there is no place-name evidence that this was also true in early medieval times, only that some stretches of some of these rivers were used, especially the Trent.

The non-Roman routes plotted on the final map thus fall into three groups: firstly, the salt ways and the Gough/Ogilby routes for which there is good (salt) place-name, documentary or map evidence, and which are well supported by the place-name evidence presented here; secondly, routes suggested by the place-name evidence and which also appear among the many other routes suggested on other less secure grounds by other authors: the place-names confirm that a few ridgeways and prehistoric routes were in use in early medieval times, but for most of them there is no place-name evidence; thirdly, there are place-names suggesting a route which has not been put forward, as far as I am aware, by any other author. In addition to these routes, lesser Roman roads (extra to those shown on the O.S. Map of Roman Britain) were added, derived from Margary, the Viatores and other sources noted elsewhere.

The addition of these extra routes to the basic Roman roads map has produced a network that embraces the majority of the places plotted on it. The main reasons for places not being incorporated in the network are: firstly, that they are by a route not yet suspected of being old (for instance, some in Staffordshire) - further detailed local investigations may reveal these; secondly, they are near several roads and it is not clear to which they refer (for instance, Farmington GLO (SP 1314) is close to three roads and nearby Calcot (SP 0910) to two, and it is not clear if they are signalling the use of the Fosse Way, a salt route, the Gough route or even all three; as a result none are shown as being in use). This uncertainty arises in many places and leaves the network of roads-in-use looking sparser than it really is. Thirdly, some of those not incorporated occur on big monastic estates and were connected with their local journeys, for instance Brigham in Holderness.

The routes in southeast England illustrate the application of these methods and some of the decisions that have to be made (see maps: figs 9.1 and 8.3). The Roman road from London to Chichester, M 15, has a DB mere-tūn (Merton), a DB äwiell (Ewell), a DB ritu (Leatherhead) and a DB anstig (Anstie Grange) indicating a road-in-use from London to

\footnotetext{
${ }^{3}$ Grundy, Highways Wiltshire, pp. 69-194; Hooke, Landscape.

4 Andrew Sherratt, 'Why Wessex? The Avon Route and River Transport in later British Pre-history', The Oxford Journal of Archaeology, 15 (1996), pp. 211-234

s Bryony Coles, 'Trisantona rivers: a landscape approach to the interpretation of river names', The Oxford Journal of Archaeology, 13 (1994), pp. 295-311,
} 
Alfoldean. Here there is a junction with M 151, and so the 10 miles stretch south of Anstie Grange has to be curtailed at this point, after $61 / 2$ miles, because here there is a choice of routes. A decision has to be taken whether to take the route northwest along M151, or continue southwest towards Hardham, the next road junction (with M 140). The stretch from Alfoldean to Hardham has no indicative DB place-name along it but there are two post-DB oras, Nowhurst and Rowner, suggesting that this stretch was in use post-DB. Nowhurst would warn the north-bound traveller of the junction of $M 151$ and $M 15$. The stretch from Hardham to Chichester has a DB yfre (Bignor), and a DB strät-tūn (Strettington), and a post$\mathrm{DB}$ ora (Nore Hill), along it, so this stretch was in use by the time of DB. It is reasonable to assume that the whole route from London to Chichester was in use in Anglo-Saxon times. The route, M 150, from London to Hassocks (at the junction of M 140 with M 150) has a DB strēet-häm (Streatham), and a pre-DB strēet-tūn, indicating use of the northern half by the time of DB. The southern half has a late ēwiell (Awell Barn 1526), a post-DB yfre, River's Farm, and a late öra (Bolnore 1559) hinting that this route was in use post-DB. Nearby is an anstig (Ansty 1313) and a curious cluster of four stigs (all thirteenth century, but not shown) There was obviously an area of interest around here, but I do not know what it was. The Roman road London to Lewes, M 14, has a DB wic-häm on it to hint at use as far as the Pilgrims Way. In the Weald is a short stretch near Tugmore (ora, c. 1095), the site of Roman iron diggings, and Hodore (ōra, 1274) on the other side of the nearby Medway; Millbrook, an Anglo-Saxon iron-smelting site, is only about 5 miles away to the south. The absence of indicative names along much of $\mathrm{M} \mathrm{14}$, and the presence of a DB yfre (Hever), a pre-DB orra (Ashour 1044) and a post-DB ora (Vexour 1275) on the Medway, suggests that this site was reached by river and not road.

The Roman road from Rochester to Hastings, M 13, has no indicative place-names along it between Rochester and the junction with M 130 near Benenden. South of Benenden there is a DB strāet and two post-DB orras (Great Cornes, 13th century, and Ore, 1121-5), close to the Roman iron- workings at Beauport Park. Access to this area was more likely to have been by sea through Bulverhythe (1135-54) or its predecessor near Hastings, or through the Rother estuary by way of Small Hythe (13th century).

A number of roads radiate from Canterbury; the one to Thanet $(M 111)$ is marked by DB Sarre and a post-DB gewced (St. Nicholas at Wade, 1456). The branch to Reculver, M1 10, is marked by a post-DB orra (Oar), although this is a sailor's landmark rather than an overland traveller's, as is Stonar (1203) near Richborough; the road to the latter, M10, has a DB wichäm on it. The road from Canterbury to Dover, M la, is marked by a DB brycg (Bridge), a DB wīc-hām and a pre-DB äwiell (Temple Ewell). Only a short stretch of the road M 12 near Hythe (1052) can safely be highlighted, because one cannot be certain if the route goes along the Roman road M 131 to Maidstone or the M 12 to Canterbury. As the former has no indicative place-names along it, that seems unlikely to be the road-in-use, whereas the route to Canterbury passes a post-DB Merton (mere-tün 1327). The important route Canterbury to London, M 1c/M 1b, has only a post-DB $\bar{e}$ wiell (Ewell Manor 1226) on it at the eastern end. The road otherwise looks unused, but there are two important 'river + ford' names; Crayford (1199) and Dartford (DB) and a ceaster Rochester ( $8^{\text {th }}$ century) which would be helpful clues to the traveller, and one must presume that it was in use. ${ }^{6}$ One close parallel is a road which must have been in use in the earliest days of Anglo-Saxon settlement, and that is the $M 3 \mathrm{a} / \mathrm{M}$ 3 b, London to Colchester, where there are four ford names - Stratford (DB), Ilford (DB, and river name), Romford (1177) and Chelmsford (DB) - before any other DB indicator is reached. A second close parallel is the northern part of the Icknield Way also marked by ford

\footnotetext{
${ }^{6}$ The eleventh-century document known as 'Rochester Bridge-works List' which details who was responsible for the upkeep of various sections of the bridge implies strongly that the route was used (see Brooks, Communities, pp. 231-3)
} 
names. As described later under Icknield Way, some of the indicative place-names are absent along these two Roman roads because they are not appropriate to local conditions - there are no landforms suitable for a cumb-tün site, no need for mere-tüns in a countryside with adequate streams for water supply, no pressing need for drceg-tūns or drceg-cots

Near the south coast there is good evidence that the route Hardham to Lewes, M 140, and on to Pevensey, M 142, was in use, with two strēts, three DB and one post-DB öras (Oreham, Warningore, Sidnor and Cudnor) and a wic-häm (1073). Nearer the coast is some evidence of the use of the Roman road, M 153, Chichester to Portslade; Strettington, at the junction of M 153 and M 15, could equally well refer to this road as the other, while the crossing of the Adur is referred to in Portslade's geläd (DB). By the time of the Gough Map (c. 1360) the emphasis has shifted to the more northerly route, M 140, Hardham to Lewes. The crossing at Portslade was difficult and tide-dependent; in the meantime the Adur had been bridged at Bramber, and naturally most travellers preferred this easier route (see maps: figs 6.3 and 6.4). One of the routes over the South Downs to the coast was well signed, M 141, from Selmeston to Newhaven passing by a DB öra (Sidnor), a DB cumb-tūn, and a DB denu-tūn. On the western edge of this area is a route from London to Portsmouth; it is noted by both Ogilby and Gough from London to Guildford. It is not well served with indicative place-names: only a $13^{\text {th }}$ century strāt-ford between London and Guildford (not thought to refer to a Roman road), Guildford itself, and then three post-DB oras in the knot of hills around Hindhead and Haslemere (one of which I cannot pin-point). Butser Hill (an ora recorded in a charter boundary of $956,\left(13^{\text {th }}\right.$ century $)$ ) was a good landmark, and by then Portsmouth was within a day's journey. This would appear to be a route which became much more important after the Conquest than it was before.

The same principles have been applied to identifying routes-in-use in other areas, and the results are discussed in the following order:

a) The routes radiating from London

b) The East Anglian network (fig. 9.2)

c) The Northern Counties (figs 9.3 and 9.4)

d) The network around York and Tadcaster (figs 9.3 and 9.4)

e) Lancashire north of the Mersey (fig. 9.4)

f) The Welsh Marches (fig. 9.5)

g) Salt routes (figs 9.4 and 9.5)

h) Routes from Gloucester (figs 9.5 and 9.6)

i) Central Southern England (figs 9.1 and 9.6)

j) The Midlands (figs 9.4 and 9.5)

k) The West Country (fig. 9.6)

\section{a) Long-distance routes radiating from London}

London to Dover is covered in the section on the Southeast (above)

London to Colchester is covered in the section on East Anglia.

London - Water Newton - Newcastle - Berwick (figs 9.1; 9.2; 9.3; 9.4). This route could have followed Roman roads all the way, but the place-name evidence suggests that it did not. Evidence for the use of $\mathrm{M} 2 \mathrm{a}$ to Braughing is slight - just a funta (Cheshunt, DB). At Braughing there is a choice of routes to Godmanchester: both Gough and Ogilby use the middle one (M 2b) through Royston, but this seems to be a later usage, for there are no indicative place-names along it. The western route through Baldock and Sandy (M 22) passes Hare Street (herestrāet 1498), runs close to a minor mere (Cromer 1191), Caldecote (DB), Stratton (DB), Biggleswade (gewoed, DB) where a minor road comes in, and Caldecote (1242); then it passes Stratford (1325) and another Caldecote (1242). The eastern route (not Roman) went by way of Hare Street (herestrōet, 1472), Barkway (weg, DB), and Fowlmere 
(DB) to Cambridge, then along M 24 to Godmanchester passing Dry Drayton (DB) and Fen Drayton (1012 (12 th century)). From Alconbury Hill north of Godmanchester there is a choice of three routes to the crossing of the Nene at Wansford (972-92 (c. 1200)) described in Taylor. ${ }^{7}$ The western one goes through Coppingford (DB, the traders' ford) and follows the Bullock Road probably to Wansford; ${ }^{8}$ the middle one goes through Sawtry, Glatton, Denton (972-92 (c. 1200)), Caldecote (DB) and Haddon to Chesterton and Wansford. The eastern one, a Roman road, $M 2 b$, from Godmanchester to Water Newton has no indicative placenames along this stretch. Either or both the other routes seem to be those favoured in AngloSaxon times. M 2c (Water Newton to Lincoln) crosses the Welland at Stamford (922) passes through Stretton (DB), leading the traveller by Wellingore (ofer, 1070-87) and a lost Caldecote to Lincoln, thence via M 28a passing Sturton by Stow (DB), Marton (DB), and Sturton le Steeple (DB) to Bawtry. The alternative to M 2/M 28 is by way of Sewstern Lane to Newark. The only indicative name on this is Denton (DB), but as it is in the angle between Sewstern Lane and a salt route from Bicker Haven to Six Hills LEI, one cannot be sure which route(s) it indicates. The Gough and Ogilby maps show another possible route through Grantham to Newark, but this has no indicative place-names. Once the Fosse Way has been crossed at Newark it is $151 / 2$ miles along the Gough/Ogilby route to West Drayton (DB) a difficult crossing of the Meden and Maun, then by Morton Grange (DB) to Bawtry. Some travellers may have preferred to cross the Meden and Maun, when united as the river Idle, at East Retford; there is an éa-tūn on this route and so perhaps travellers wishing to link up with water-borne traffic would have preferred it. Martin (DB) is passed on the way to Doncaster. Shortly after there is again a choice of routes, firstly M $28 \mathrm{~b}$ via Castleford ( 948 , Ceasterford), Sturton Grange (DB), and Aberford to the junction for Tadcaster, a route favoured by Gough, and secondly a diversion through Ferrybridge to Aberford; the ferry was superseded by a bridge in the $12^{\text {th }}$ century attracting travellers away from $\mathrm{M} 28 \mathrm{~b}$ to the route detailed by Ogilby. For comments on the route north of Tadcaster, see the section on the Northern Counties.

London to Chester along Watling Street, M 1 (figs 9.1, 9.2, 9.5, 9.4)

There is little to indicate that the stretch between London and Dunstable was much used in Anglo-Saxon times - indeed it was reported by a thirteenth century monk that a mid-eleventh century abbot of St Albans, an abbey which lay on it, was so concerned about the dangers faced by pilgrims to the shrine from wild animals, robbers and outlaws that he had the woodland cleared well back from the road all the way from the edge of the Chilterns to the northern edge of London. ${ }^{9}$ The ordinary travellers may have preferred to use a safer route and access the more north-westerly stretches of Watling Street from the Icknield Way. Just beyond Dunstable the road passes Bidwell $\left(13^{\text {th }}\right.$ century) and Calcutt Farm (1224), then Fenny Stratford (1252), and Stony and Old Stratford (1202, 1278). Just beyond Towcester, Caldecote (1203) is passed. A little further north, the place-name evidence suggests that the Roman road was not used between this turning and High Cross, but instead an alternative was used via Coventry, shown by both Gough and Ogilby. This passed through Drayton (1021-3) near Daventry, crossed Dunsmore Heath near Draycot (1203), crossed the Fosse Way near Stretton on Dunsmore (DB, which could have served both roads). It continued through Coventry emerging on the western edge to pass Coundon ( $\bar{e}$ wielm, DB), through Meriden (Alspeth in DB), by Water Orton (?ofer, 1262) and so to rejoin Watling Street, $M$ $1 \mathrm{~g}$, near Weeford. At Pennocrucium (Water Eaton, 940) M 1 forks: the north-west branch, M 19, goes to Chester, and passes Stretton (DB) and Lindore Farm (1323), negotiates one wet

\footnotetext{
${ }^{7}$ Taylor, Roads, pp. 120-4.

${ }^{8} \mathrm{PN} . \mathrm{BDF} / \mathrm{HNT}$, pp. $237-8$

${ }^{9}$ Cooper, Rise, p. 65; Gesta Abbatum Monasterii Sancti Albani, ed., Henry Thomas Riley (Rolls Series 28. 4a, 1867), pp. 39-40
} 
area at Aqualate (gelād 1227) and another called Longford by Market and Little Drayton (DB) and Moreton Say (DB). After Whitchurch M 19 passes an Overton (?ofer DB), Stretton ( $12^{\text {th }}$ century), Caldecott (DB), Overmarsh (ofer 1208-29) before crossing Handbridge (DB) into Chester. The western fork, M 1, goes to Wroxeter via Drayton

The diversion through Daventry and Coventry, leaving Watling Street from Weedon to High Cross without indicator place-names, seems to have happened well before the Conquest. However, the stretch from High Cross to Weeford was well used, perhaps by travellers coming north along the Fosse Way and wishing to go to Tamworth or further.

London - Radnor - Aberystwyth (figs 9.1 and 9.5)

The route shown by Ogilby is paralleled in stretches by a Gough route (London to Wheatley) and by a salt route near Moreton-in-Marsh with which it shares indicative placenames. The London end is marked by Drayton Green MDX (1387). After a gap of about 30 miles Lewknor (c.994) is reached, then the herepath ford at Wheatley (956), Shotover (DB), Little and Long Compton (1005), Coldicote (1248), Moreton-in-Marsh (714), Batsford (71643), Broadway (972), Pershore (972), Readan ofre near Worcester (969), ?Mapnors (c. 1220), Hennor (1123), Bradnor (1216-72) and Radnor (DB).

London - Bath - Bristol (figs 9.1 and 9.6)

This route left M 4a at Hounslow, crossed the Colne near West Drayton (939 $\left(13^{\text {th }}\right.$ century)), went close to Biddles Farm (byden-welle, 1208) now in Slough, crossed the Thames at Maidenhead (hỹth, 1202), passed Calcot (13 ${ }^{\text {th }}$ century) just west of Reading and came to Speen near Newbury. The Gough and Ogilby routes go on through Hungerford and Marlborough, but the earlier route may have followed M $41 \mathrm{~b}$ passing Bagnor (ora DB) and Boxford (öra 960) before following M 53 to Marlborough. From here the Roman road M 53 passed Beardwell (byden-welle, 1353) before reaching Bath and Bristol, where it joined the more northerly Gough/Ogilby route from Marlborough; this passed Compton Basset (DB), probably, but not certainly, associated with this route, Chippenham, and thence to Bath or Bristol, although there are no further place-name clues.

London - Winchester - Exeter - Cornwall (figs 9.1, 9.6)

The Gough map shows a route from London to St Ives, Cornwall. The place-name evidence suggests that the stretch from London to Yeovil was in use in Anglo-Saxon times The route led to Kingston-on-Thames followed by Stratford Farm (in Ockham, early $13^{\text {th }}$ century) although the road is not thought to be Roman, crossed the Wey at Guildford, turned west along the Hog's Back (Harroway) passing Compton (DB), to Farnham. There is then no place-name evidence of the Harroway being used until it reaches Somerset (see below, $\mathrm{k}$ ).

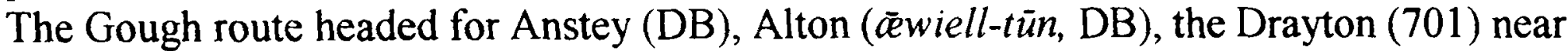
Alresford, and so to Winchester. Then the Roman road, M 45a, to Old Sarum was followed, passing Compton (DB) and Houghton Drayton (1267) at the crossing of the Test. From Old Sarum the river Avon was crossed at Stratford sub Castle (1091), but after crossing the Nadder the route left the Roman road M $4 c$ and turned west along the Salisbury Way, a herepceth ${ }^{10}$ along a scarp crest, with views into Compton Chamberlayne (DB) and the steeply-backed embayments of Burcombe Ivers (937), Compton Ivers (1328), Sutton Ivers (1840, all yfre) as well as Ansty (DB) (see fig. 8.5). The complex of oras around the royal vill at Wardour is close by (see vol. 2, pp. 230). From Shaftesbury the route went through East and West Stour where the directional ofers Stour Estouere (1371) and Stour Westouere (1268) refer to the river banks and possible trans-shipment points, past Over and Nether Compton (946-51), to Yeovil, after which there are no indicative place-names until $\mathrm{M} 4 \mathrm{f}$ is joined at Honiton when it is marked by Straightgate Farm (1061(1227)) and Strete Raleigh (DB) (see also section $\mathrm{k}$, the West Country).

${ }^{10}$ Grundy, Highways Wiltshire, pp. 106-8. 


\section{London - Portsmouth (fig. 9.1)}

This follows the London to St Ives route as far as Guildford, but then heads for Hindhead probably passing Wakemills and Haslehurst (both öras, 1332, 1332, GR of latter unknown), and Waggoners Wells (öra c. 1260). The next notable landmark is Butser Hill (óra $956\left(13^{\text {th }}\right.$ century)) and the route reaches the coast at Havant. This route is poorly marked south of Guildford and only with öras, which suggests it existed from an early date but was not much used.

\section{b) The East Anglian Network (fig. 9.2)}

There are two problems with tracing routes in East Anglia; the first is the lack of EPNS coverage for Suffolk and much of Norfolk, and the second is the lack of traces of Roman roads across the Sandlings bordering the east coast - the well-drained nature of the ground meant that it was unnecessary to construct anything very substantial. ${ }^{11}$ The road network and the place-name evidence are thus incompletely known.

Two Roman roads head out of London. The first, M3, leads to Colchester and Norwich; after crossing the Lea at Stratford (DB) it crosses the Roding at Ilford (DB) and the Rom at Romford (1200), passes Hare Street (1344) and Calcott Hall (1319), and crosses the Chelmer at Chelmsford (DB). There are no other DB indicative place-names along this stretch, and in this it resembles the M 1 London to Canterbury road and the northern part of the Icknield Way, which are also reliant on ford place-names. North-east of Chelmsford the indicative place-names appear: Walter Hall (foer, $1062\left(12^{\text {th }}\right.$ century)), Hubbridge Hall (DB), Ewell Hall (1212), Stanway (c. 1000 (11 $1^{\text {th }}$ century)), and so to Colchester. Stratford St Mary (c.995) follows, but then the trail becomes faint. In east Suffolk the network is hard to piece together because there are no traces of Roman roads over the Sandlings although the names Stratton Hall (DB) and Stratford St Andrew (DB) indicate that they existed. Stratton Hall was in all likelihood on a road between Walton Castle (a small, coastal Roman fort) and Ipswich. Dunwich was a flourishing commercial centre, but coastal erosion has slowly destroyed the site. However, in earlier times it would have had road links to places in East Anglia; there is some place-name evidence for a link from Colchester via Baylham, Wickham Market (DB), Stratford St Andrew and then possibly by Eastbridge (DB) and so to Dunwich. A link north to Norwich would probably have used M 35, Peasenhall to Pulham St Mary. There are three place-names suggesting this, all rather debatable: Semere Green is a DB mere at the junction of M 35 with M 3 (Norwich to Baylham) usefully placed but barely qualifying as a mere-onchalk since here the chalk is overlain by boulder clay; Weybread is right on the line of M 35 where it crosses the Waveney; DEPN and CDEPN favour an interpretation as 'broad way' (though Gelling has some doubts). If it is a weg it is, like Stanway ESX, atypical in that it refers to a Roman road and is not steep. Lastly, Stradbroke is over 3 miles from M 35, but is on a brook which joins the Waveney at Weybread, and the name could be taken as meaning " the brook which leads to the Roman road (at Weybread)'. To return to the ColchesterBaylham-Norwich route: north of Baylham it passes Wickham Skeith (DB), Semere Green (DB) and Long Stratton (DB), indicating that this was a route in use from London to Norwich.

There are only two ōras (Stonner Point and Orford) and no ofers known in East Anglia, both are coastal and indicate landing places on the river Deben (close to Sutton Hoo), and river Alde both of which give access to the seventh century royal centre at Rendlesham. Rendlesham is close to the presumed Roman road through Stratford St Andrew; Orford remained an important port into the later medieval period.

\footnotetext{
${ }^{11}$ Norman Scarfe, The Suffolk Landscape (London, 1972), pp. 65-6
} 
Norwich is not well linked into the road-system, apart from M3 and the possible route from Dunwich (above). M 33, Chelmsford to Stanton Chare and M 331, Stanton Chare to Attleborough, have no indicative place-names along them, except for the inconclusive Long Melford (DB) and Bulmer (DB, on London Clay overlying chalk) which on their own are not safe indicators. There is, however, good evidence for a road from Norwich leading northwest through Drayton (DB), past Deighton Hills (1155), crossing the Wensum at Attlebridge (DB), passing close to Morton Hall (1196), going through Lenwade (gewced 1198-9) where it re-crosses the Wensum, to reach $M 38$ at Bawdeswell; $2 \frac{1 / 2}{2}$ miles to the west the Roman road crosses the Wensum at Billingford (DB). Deighton Hills take their name from Dittona, and the dic is likely to refer to a raised track. ${ }^{12}$ This road is referred to as "... super viam que vocatur Stongate' in a grant dated $1272-89 .{ }^{13}$ This route presumably led to northwest Norfolk, where the only indicators of route-ways are the 'element + mere-on-chalk' names; four DB examples are known (Anmer, Southmere, Egmere and Barmer), and a later Shammer (1210-15). Inmere might be an example, but no early spellings are available. All six are by Roman roads, and would have been very necessary sources of water in this dry country. The ferry across the Wash to Skegness (Tric, DB) would have left from the vicinity of Holme, while the river Heacham with its $\bar{e} a-t \bar{u} n$ might also have given access to these routes.

The northern part of the Icknield Way between Holme and the crossing with M 24 near Babraham CAM, after passing Sedgeford (DB), Inmere (no spellings) and Anmer (DB), goes through Narford (DB), Stanford (DB), Thetford (DB), Lackford (DB) and Kentford (t. Wm I). There are no other indicative place-names along this stretch. This countryside, with its low, gently rolling hills, had no situations in which valley terms such as cumb-tün and denutün would be appropriate, no steeply sloping wegs, no powerful rivers where terms for difficult crossings would be needed, no steep slopes or flood-prone areas where assistance from the people of a drceg-tūn or drceg-cot would be appreciated; $\bar{o}$ ra and ofer were hardly used in East Anglia. Consequently, the terms mere and ford were really the only appropriate indicative place-names that could be used on this stretch. The nearby Roman road M 33 does not even have ford names where it crossed the Nar and Wissey; even the mere-tūn it passes refers to a natural mere, and so it is not necessarily indicative of a route in use.

Northern and western Norfolk were linked to the East Midlands by the Roman road across the Fens running from Water Newton near Peterborough through Funthams (funta, $13^{\text {th }}$ century) near Whittlesey, through Denver (foer, DB) the crossing of the (eastern) Ouse, Stradsett (strëet, DB), then crossing the Icknield Way and Peddars Way, and probably continuing to Billesford, thus linking up with the road into Norwich.

The western fringes of Norfolk and Suffolk are bordered by the Fens, where movement by water was usual. A series of hÿths - Setchey (1202), Methwold Hythe (1227), Otringhithe (DB), Lakenheath (945) - were the trans-shipment points between water and land-borne transport, but only Otringhithe was close to a Roman road, M 332, leading east to the Icknield and Peddars Ways. In fact East Anglia was more easily reached by water through its series of $h \bar{y}$ ths and its estuaries than it was overland from London or the Midlands.

A road heading west from Colchester, M 32/M 22, is marked (if Stanway be included) all the way to Godmanchester, passing through Dunmow Ford (olim Stratford, $13^{\text {th }}$ century), bypassing Bedlar's Green (byden-welle, 1229) and Wickham Hall (DB), going through Hare Street (1498), Cromer (on boulder clay overlying chalk, mere, 1191), Caldecote (DB) and Stratton (DB). Next are Biggleswade (gewaed DB, probably referring to a feeder road), Stratford (1325) and so past Caldecote Manor (1242) to Godmanchester.

\footnotetext{
12 The Charters of Norwich Cathedral Priory, 1, ed. Barbara Dodwell (Pipe Roll Society, 40, 1965- 6), p. 210

${ }^{13}$ The Charters of Norwich Cathedral Priory, 2, ed. Barbara Dodwell (Pipe Roll Society, 46, 1978-80), p. 91.
} 
Although the Roman road, M 30, London to Dunmow was in use, there is little evidence that that from London to Braughing, M2a, was; only Cheshunt, a funta (DB), lies on it. It is a route shown on the Gough map and detailed by Ogilby, suggesting that it came into more frequent use relatively late. Further north, the earlier route from Braughing to Godmanchester was either the one through Baldock M 22 (see p. 109) or else the one through Barkway and Cambridge; this passes Hare Street (1472), Anstey (anstig, DB), Barkway (weg, DB) and Fowlmere ('element + mere-on-chalk', DB) en route to Cambridge, and is a Gough route There are two droegs between Cambridge and Godmanchester. The Roman road M $2 b$ from Braughing to Godmanchester has no indicative place-names along it, although it later becomes part of Ogilby's route to Berwick.

\section{c) The Northern Counties: north of Boroughbridge (figs 9.3 and 9.4)}

There are few place-names recorded by 1086 in the northern counties, largely because they were not covered by the Domesday Survey, and so few stretches of road can safely said to be in use at the time of the Conquest from the place-name evidence. There is, though, a good scatter of names recorded post-Conquest.

The route of the Great North Road can be traced using Ogilby's Road Atlas. It is likely that this is the route known to and mapped by Matthew Paris c. 1250; the Paris map shows the same sequence of towns between Canterbury - London -Durham - Berwick, but it is far too crude to be able to identify the exact roads. The Gough map of c1360 shows a route originating in London and heading north, but at Scotch Corner near Richmond it bears northwest to become a trans-Pennine route following a Roman road to Carlisle. In addition, a number of drove-roads crossed the Cheviots, such as Salters Road, Clennell Street, The Street and Dere Street/Gamelspath.

The only places on M 2e/M 80a, North Ferriby to Durham, are a Murton Farm (mōr-tūn, $\mathrm{DB}$ ) in Sutton in the Forest and Morton Palms (mōr-tūn, 1208-10) near Darlington, but mōrtün on its own is not a reliable indicator of a road-in-use. Nearby Marton in the Forest is thought by Watts to derive from ON marr, and therefore may not be an example of a meretün as suggested by Ekwall. ${ }^{14}$ The evidence for $\mathrm{M} 2 \mathrm{e} / \mathrm{M} 80 \mathrm{a}$ being in use is therefore very tenuous. It is a little better for $\mathrm{M} 8 \mathrm{~b}, \mathrm{c}$, and $\mathrm{d}$, Boroughbridge to Corbridge and beyond. The presence of Marton le Moor (mere-tūn, 1198) suggests the stretch near Boroughbridge was in use, but then there is a gap until just before the road junction at Scotch Corner is reached; thereafter Piercebridge (c.1040) indicates use. North of Piercebridge there is a Denton (1200), then Binchester. The presence of Brancepeth (1170) on M 83 hints at a link between M 8 and the Great North Road (at this point coincident with M 80a). M 8d negotiates a gully through Rag Path Wood (no spellings), passes through Lanchester where it is joined by Peth Lane (1284) and continues through Ebchester to the crossing of the Tyne at Corbridge (c.1050). It seems that along this route surviving bridges, remains of Roman forts and the peth names (with the North Country sense) were adequate guides for the traveller. There is slender evidence - a Denton (1180) - of a link from Corbridge to Newcastle, and then along the Great North Road, past a lost Denton (1359) to the crossing of the Wansbeck at Morpeth (1200). Some 10-11 miles north of Morpeth, one of the rare North Country ofers, Overgrass (1255), is to be found. It lies between the Great North Road and M 87. As Overgrass is the last significant name near the Great North Road and at the start of a marked stretch on M 87 (both heading north), it suggests, as oras and ofers often do, that here is a change of direction for the traveller, and that he should transfer from the Great North Road to M 87, or vice versa if going south. The steep little hill at Glanton ( $\mathrm{OE}$ glente 'look-out') might catch his eye (lookouts are often found by route-ways), otherwise his next landmark would be Wooler

\footnotetext{
${ }^{14}$ See discussion of mere in Chapter 5.
} 
(1186), 'the ofer with the springs', referring to Weetwood Moor. It is not eye-catching from the south (much better from the north as is Overgrass), but is the cue for forking left to Wooler and a nearby mere-tūn, Coldmartin (1195), thence to the Northumbrian royal centre at Yeavering (Gefrin) or later Milfield (Melmin) (floreat c.605-685). ${ }^{15}$ A traveller from northern Northumbria southbound would also use Wooler to guide him to Yeavering or Milfield, or to turn east for Bamburgh (see vol. 2, p. 238) As this was a royal centre for less than a century, and if Wooler really was named to aid travellers to find it (council meetings may have been held there), then ofer must have been in use as a 'signpost' term by the seventh century, paralleling the early use of ora.

Two of the tracks over the Cheviots have names indicating use: the Roman road Dere Street, M 8f, from High Rochester to Newstead is in part called Gamelspath (1380), and an alternative part of Clennell Street, known as Yarnspeth (1233), leads down to Uswayford (Uswaiburne, 12c.). This route passes close to Hudspeth (1252) and Soppit (peth 1292) on leaving the Cheviots going south. There are no names suggesting water transport north of the Tees.

A trans-Pennine route for travellers from the north leaves along M 820 near Binchester, heading for Bowes and passing two ströts, both DB (Streatlam and Startforth). At Bowes M 820 is joined by M 82 (a Gough map route) from the south. Merged together, they follow the Stainmore Gap to Brough, at which point the traveller is still 11 miles from Long Marton (mere-tün, c. 1170), the next indicative place-name. The crossing of the Eamont at Penrith (ritu, 1167-1290) is a further 8-9 miles and Carlisle another 15-16 miles. This route has few indicative place-names; as it follows such a clear-cut feature as the Eden valley they are probably not necessary. In Carlisle are Caldecotes (1253) and nearby Morton (1214), probably indicating the later part of the route, although as Carlisle is at a cross-roads it is hard to know which routes they refer to. The presence of a Denton (c.1169) on M 85b suggests this was used, and by M 75 between Papcastle and Egremont is a Murton (1203), hinting that this too was used.

There is sufficient evidence to identify a few routes in northern England, but it is a sparse network. The place-name evidence may always have been sparse, but evidence could have been lost because so few documents survived the Viking invasions. The disruption caused by these may have resulted in some names being lost or changed. The route-way terms are fewest and furthest between where the ON names are most plentiful.

\section{d) The network around York and Tadcaster (figs 9.3 and 9.4)}

The main route centre in this area was Tadcaster, both in Roman and Anglo-Saxon times. Approaching from the south, M 28b, having passed through Castleford, passes Sturton (strēt, DB), by-passes Tadcaster to the west, and, on a road known as Rudgate (M 280), proceeds past Hunsingore (ofer, DB) to join M 8a from York near Whixley, and then, as M 8b, heads towards Catterick. Alternatively, the traveller could take the road M 28c through Tadcaster, passing Street Houses (1293) and an anstig (DB, a wapentake meeting place) to York. The M $28 \mathrm{c}$ continues eastwards, becoming M 810/M 811, to Bridlington, passing Murton (mōr-tūn, DB), crossing Stamford Bridge (c. 1075), and climbing the North York Moors to Fridaythorpe, where the road forked; the southern unmarked branch M 810 went via Kilham, whilst the northern branch, a Romanised ridge-way, M 811, went by way of Fimber (112137) and Sledmere (DB), both meres-on-chalk.

The Great North Road (Ogilby's route), approaching Tadcaster from the south, diverged from the Roman road 7 or 8 miles north of Doncaster and passed through Ferrybridge. In DB

\footnotetext{
${ }^{15}$ Brian Hope-Taylor, Yeavering (HMSO, London, 1977), pp. 276-7, 279.
} 
it was known as Ferie; the bridge was built in twelfth century, ${ }^{16}$ probably attracting travellers away from the Roman road route.

Two routes led westwards following Roman roads, M 72 to Ribchester and M 712 to Manchester. M $72 \mathrm{~b}$ passes Compton (DB, the only cumb-tün in northern England), then Denton (c.972), Draughton (drceg-tūn, DB), Stirton (strēet-tün, 1159) and East and West Marton (mere-tün, DB). Nearby Painley (DB) represents a feeder path. There are no indicator names close to Ribchester to show that M 72a was in use there, but hints in the form of a Coldcoats (1243) and a Moreton (1246) that the salt route southwards might have been used instead. The other route west from Tadcaster to Manchester, M712, passes Thorner (ofer DB) at a road junction, then Caldecote (DB). At Southowram (ofer, DB) there is a choice of routes; either the Roman road or else a salt way. There are no indicator names on the Roman road, but there are sealt names, e.g. Saltergate dating back to c. 1200, scattered along the salt way and a Denton (c. 1220) on the outskirts of Manchester. This was apparently not such a well-used route as the more northerly one, M 72.

\section{e) Lancashire north of the Mersey (fig. 9.4)}

Neither of the Roman roads going north from Warrington (M70) or Manchester (M7) has any route-indicating place-names along them; even the mere-tüns are not relevant, as here they refer to natural meres. There is little sign of activity at all in Lancashire except along the coast, where there are staithes and hithes. It was difficult to penetrate far inland because of the marshes, moors and peat-bogs, but in Fylde there was an ofer, Preesall (1094), near the mouth of the Wyre, suggesting that it was used by shipping. Inland, south of Bowland Forest, Core (ofer 1228) might have signed the way to Chipping (1203, céping 'a market'), or even further.

\section{f) The Welsh Marches (fig 9.5)}

The Roman road M6, parallel to the Welsh border from Chester to Whitchurch, Wroxeter, Leintwardine, Kenchester/Hereford and probably on to Monmouth, was well-supplied with indicative place-names. It would have been an important route for the movement of patrols along the Welsh border, as well as for other travellers.

On leaving Chester, the traveller would have gone through Handbridge (DB), passed Eaton Hall (c.1050) on the Dee, crossed the river at Aldford (1153 'old ford'), passed an ofer, Overmarsh (now King's Marsh, 1208-29) at the cross roads with a salt way from Nantwich, and proceeded through Stretton (12c.) leaving Caldecot (DB) and Grafton (1319) a little to the west. Just after Overton (?ofer, DB) the traveller would have forked right along the M $6 \mathrm{a}$, passing Moreton Corbet (DB) on the way to Wroxeter; further south he passed through All, Church and Little Stretton (DB), passed close to Stanway (DB) in Adforton (a feeder road from the west), Street Court (DB), Stretford Court (DB) and Chadnor (ofer, DB). The route to Hereford, M 6c, led through Portway and Holmer (mere, DB) before crossing the Wye at Hereford (958). To the south, the route passed Grafton (Hy 3), another Portway, Orcop (orra, 1137) and so on to Monmouth.

Several roads led off or crossed this major route. In the north, as mentioned, a salt route from Nantwich crossed it at Kings Marsh and went west past a lost Denton (1319). From Wroxeter, M 64 went west through Stoney Stretton (1255), following the valley route through Marton (DB) and so to Wales. There were other signs of activity near Wroxeter: a Grafton (1291) opposite Yeaton (éa-tūn DB) on the river Perry suggesting that coppice products were being moved downstream from here; Eaton Constantine (DB) and Dryton (drceg-tün, c.1227) near the Severn, beside a possible Roman road running southeast from

\footnotetext{
${ }^{16}$ CDEPN, s.n. Ferrybridge.
} 
Wroxeter; Eaton Mascott (DB), on the Cound close by M 6b; and Condover (ofer DB) beside SaltersWay. ${ }^{17}$

A cluster of ofers near Church Stretton indicate a possible route from M 192 over Wenlock Edge through Stanway (DB) and past Hazler Hill (ofer 1255-6) into the Church Stretton valley. Nover's Hill (? Ofer, 1840) signalled a route up the Cardingmill Valley onto the Long Mynd; thence, using Overs (DB), Gravenor (ofer, 1291-2) and Wentnor (ofer, DB), the Roman lead-mining area around Shelve could be accessed.

Another by-road crossed M 6b at Rowton, climbing steeply up View Edge beside Weo Farm (weg-höh, 1255, a very steep weg though not recorded as early as DB) and over the summit through Aldon ( $\bar{e} w i e l l-d \bar{u} n, \mathrm{DB})$ to a possible Roman road at Onibury. ${ }^{18}$

The Ogilby route London - Radnor - Aberystwyth (see under routes from London) led through a pass at Old Radnor (ofer, DB) into central Wales passing Moorcot (mór-cot, 1160 70 ) and Bradnor (óra, 1216-72) en route, with a distant view of Burcher (ofer, ante 1272).

\section{g) The Salt Routes (figs 9.4 and 9.5)}

Maddicott noted that a few of the salt routes from Droitwich ran towards Herefordshire, but that most ran south-eastwards, some ending at the Thames since no salt place-names are known south of the river. He surmised that the salt was being carried downstream to the important trading centre of London. ${ }^{19}$ The strengthening ties between Mercia and London in the later seventh century would have seen many salt traders as well as other people using the salt ways, and may have been the context in which the Gough/Ogilby route - LondonMoreton-in-Marsh - Radnor grew prominent (see p. 111).

The salt ways themselves, radiating from Droitwich and the Cheshire wiches, have been identified by Houghton, Crump and Hooke. ${ }^{20}$ These authors made extensive use of placenames incorporating the elements salt and saltere, which they found in settlement names, names of fords and roads, field names and charter-boundary marks. They also used other documentary evidence such as DB references to places with salt rights. Some of the routes they identified had numerous salt place-names along them, and so one could be reasonably certain they were well used by salt traders. Elsewhere the evidence was very sparse and the actual routes used were uncertain. In some cases the routes were presumed to exist because a place had salt rights at Droitwich, but the actual tracks could not be determined.

Only six of the salt-names assembled were those of settlements evidenced before 1500 (the criterion adopted in this study); a large proportion of the others were field and road names evidenced first in the thirteenth and fourteenth centuries, or even later in some cases. It would not be possible to reconstruct the salt ways from these six settlement names alone (four connected with Droitwich and two with the Cheshire wiches), but other indicative place-names pick out some of the routes that Houghton and Crump suggested were salt-ways, or rather routes where salt traders were often to be seen amongst the other traffic. Best marked of these is the route from Droitwich (route E in The Place-Names of Worcestershire), past Pridzor (ofer, 1270), Hadzor (ofer, 11c.), Becknor (ofer, 1216), a possible ofer at Noah's Green, Oversley (DB), Drayton (1162), and so to Stratford-on-Avon using a Roman road, M 56. Salt route A went to Martin Hussingtree (mere-tūn, 972 (c. 1250)) and then bore southeast to Wyre Piddle near Pershore (óra, 972, c. 1050); after crossing the Avon it passed Haselor House (ofer, c. 1220), climbed over Alderton Hill (Daganoran, 1002

\footnotetext{
${ }^{17}$ VCH Shropshire, viii, p. 31.

${ }^{18}$ Susan Laflin, 'Roman Roads and Ford Place-names in Shropshire', Shropshire History and Archaeology, 76 (2001), pp. 1-10

${ }^{19}$ Maddicott, London, pp. 15, 43.

${ }^{20}$ Houghton, Salt-ways, pp. 1-17; PN. WOR, pp. 4-9; Crump, Saltways, pp. 84-142; Hooke, Droitwich, pp.123-53.
} 
S901), on through Hailes, passed close to Salperton (salt-herepceth-tūn, DB), and ended at Lechlade. Although there are no indicative place-names between Salperton and Lechlade, another branch leaves salt-way A south of Salperton and runs through Compton Abdale (DB) and Cassey Compton (962) to Cirencester, where a salt trading market (le Saltewhich) was recorded in 1540; the southern part of this is a Roman road. A branch leaving salt-way A after Alderton Hill went by Stanway (1105), up the Cotswold scarp past the source of the Guiting ( $\bar{e} w i e l m 997$ (11c.)); then passing Batsford (óra, 716-43 (11c.)) it reached Moretonin-Marsh (716 (16c.)). The route on past Salford (salt-ford, $(777(12 \mathrm{c})$.$) to Chipping Norton$ and Bampton is route $\mathrm{I}$ in the Place-Names of Worcestershire. Another salt-way passing Hadzor (11c.) then passed Hollow Court (weg, DB) en route for Arrow. The evidence for the other Droitwich salt-ways consists mainly of the places with salt-rights recorded in DB. Route $L$ has Eastnor (DB) by it; route $K$ goes by Moreton Jeffries (DB) and Moreton on Lugg (DB) both HRE, - neither very reliable place-name indicators.

The Cheshire salt-ways are not well served by place-names; many of those not following Roman roads have no indicative place-names on them at all. Others have them at junctions with other kinds of routes where they may have served either or both: Whaley Hall (weg, c. 1211-25) is a case in point, where the salt-way would be seen as a feeder weg to the Roman road M 71b. Denton (1255) near Stockport is by a Roman road M 711, which has no other significant place-names along it, and it is close to the salt-way to Raistrick where

Southowram (ofer, DB) is the only significant name, but as that is where the salt way joins a Roman road, M 712, it is not a certain indication that the salt-way was in use. The salt-way into Wales passes a lost Denton (1319), as noted above; the salt-way between Chester and Middlewich passes Over (DB); as this route linked the Roman settlements of Deva (Chester) and Salinae (Middlewich) it is likely to be a route that was well established in pre-Conquest times. The sealt names are not recorded in DB or pre-Conquest sources, of which there are few; a great many occur in post-Conquest field-names, a group that is not considered in this study. This means that the Cheshire salt-ways hardly feature in the early medieval route way network as identified through the indicative settlement names. Indeed, it hints that these routes were much more used by salt traders than any other type of traveller, in contrast to the Droitwich salt-ways.

\section{h) Some routes south of Gloucester (figs 9.5 and 9.6)}

Gloucester is linked to the Roman road-system of the Welsh Marches by M 61, which crossed the Severn valley along the Over (ofer, 804 (11c.)) Causeway. This soon branched into M 610, passing Compton Green (Hy 2) and Stretton Grandison (DB). The other branch, M 611, passed a lost Morton (DB) in Churcham, and after passing Ariconium drew near the Wye at Eaton Tregoz (DB), passed by Totnor (?ofer, no date), Capler Camp (ofer, DB), skirted the Woolhope Dome, and crossed the river Frome close to Tidnor (ofer, c. 1240) to reach the Roman road to Hereford and Kenchester, M 63a.

The main road south from Gloucester, M 541, passes between Moreton Valence (DB) and Standish Moreton (1327). Shortly after passing through Cambridge (1200-10) it forks: the eastern fork, M 541a, has no indicative names along it; the western branch, M 541, goes through Buckover (ofer, 1167), passes close to Morton (1307) in Thornbury, through Over (1005) in Almondsbury, and by Easter and Greenfield Compton (1291 and $990\left(11^{\text {th }}\right.$ century)), whence it is only four miles to Sea Mills, and the banks of the Avon. Sea Mills, or at least the portus at Portishead, might have been linked by ferry across the Severn Estuary to Portskewett (from Welsh porth 'a harbour' 1065). Here a short length of $M$ 60a going north is marked by Stroat (strēet, 1061-5 (12 ${ }^{\text {th }}$ century)); a little north of Stroat, at Lydney Park and the Scowles, were Roman iron ore mines, while to the south near Portskewett was a Caldicot 
(DB); a place where travellers might wait until conditions were suitable for the ferry to run A trade in iron or iron-ore might be envisaged here

A Roman road from Bitton to the top of the Mendips, M 540, is marked by Compton Dando (DB) and, before the Chew Valley reservoir obliterated them, Stratford Bridge and Stratford Lane (no spellings) and the hamlet of Moreton (DB). The road passes Compton Martin (DB) and East and West Harptree (herepceth, DB) as it starts the ascent; the Roman lead-mines on the plateau at Charterhouse and Priddy were easily accessible.

It seems clear from the place-names that a road ran along the southern foot of the Mendips from the coast at Uphill through Bleadon and Shiplate (a possible geläd, 956), Loxton, close to Compton Bishop (1067), Axbridge (c. 910), Draycott (DB), and so to Wells. It is quite possible that Draycott was associated with the steep climb up the Mendips to Priddy and the lead mines.

The Fosse Way M 5b, south of Bath, is marked by Chilcompton (DB), Stratton-on-theFosse (DB), East Compton (1327), and Northover (1180) on the north bank of the Yeo near Ilchester - a potential trans-shipment point. South of Ilchester, the road M Sa crosses the Parrett near Drayton (1243), passes through Over Stratton (DB) but bypasses Compton Durville (DB), Street (DB) and on to Axminster. There is then a choice of route to Exeter: the more northerly one, M 4f, passes Nower Farm (1384), Gobsore (öra, 1238), Straitgate (1061 (1227)) and Strete Raleigh (DB). The more southerly route, M 49, follows a herepceth noted in the names Harepath Farm (1005 (12c.)) and Harpford (1167).

Leading northwest from Ilchester is M 51. At Compton Dundon(DB) it forks, one branch going to Street (725) and thence Glastonbury, the other following the Polden ridge passing Catcott (DB, either *calde-cot or *Cada's cot) to Dunball.

From Somerton an old route, a herepath in the Long Sutton charter (S 343), leads to Langport; this name 'long market' evidenced in 914-9 (13c.), with its Estover and Westovre on either bank of the Parrett, suggests a trans-shipment point between water-borne and landborne goods and people. The route crosses the river Isle at Hambridge and heads through Broadway (DB) and onto the Blackdown ridgeway, which probably had links to the plateautop tracks north and south of Honiton discussed under weg.

\section{i) Central-southern England (figs 9.1 and 9.6)}

Five roads are notable for their lack of indicative place-names: firstly, the Harroway from Farnham to Compton Pauncefoot (DB) just east of Ilchester; secondly, the 'lead' route from Charterhouse to Old Sarum, M 45b; thirdly, the road from Silchester to Chichester, M 155; fourthly, the Southampton-Oxford-Northampton road, which has no indicative place-names except for a cluster of three near Abingdon, probably part of a local network (Drayton, 958 (c.1240); Caldecott, 1261-6 and Hennor, c. 1200); and lastly, Silchester to Old Sarum, M 4, (see further on p. 123).

A series of Roman roads radiated from Winchester, an important centre in Wessex. The M 42b south was marked by Compton (DB) and led to the port and market of Hamwic (Southampton). Alternatively, the traveller could go west through the future New Forest along a series of lesser routes described under ōra (see vol. 2, p. 229). The Roman road M $45 \mathrm{a}$, west to Old Sarum, a Gough route, was in use as described under 'routes radiating from London'. The Roman road M 43, to Mildenhall and Marlborough, does seem to have been little used except close to Marlborough; its crossing of the Test probably shifted a mile or so to the north from Newton Stacey to near Forton, where there is a hamlet called Drayton (9951006) on the east bank and Forton (ford-tün, 1228) on the west.

The Roman road M42a, to Silchester was well used (see under 'routes radiating from London). 
The route $M 420 / 421$, southeast to Chichester, passes a Calcot House (1208) on the way to Wickham (wīc-häm, 826-12), Boarhunt (funta, DB) and Havant (funta, 935(12c.)) Evidently this route was known although the place-name evidence is not ideal

Two non-Roman routes led east from Winchester: the Gough route to London (see 'routes radiating from London); and the South Hampshire Ridgeway, which passed through the nowdeserted village of Lomer (mere-on-chalk, 802-839 (12c.)), crossed the Meon at Wamford (1053) or Exton, passed over Butser Hill (ōra, $956(13 \mathrm{c})$.$) , and skirted Wolver Wood (öra,$ Hy 3), before entering Sussex. By turning south through Compton (1015), West Marden and Funtington (funta, 12c.), the traveller would have reached Chichester.

About 4 miles north of Winchester is a stretch of herepceth running west to east between Stockbridge and Bradley, known as the Lunway. It features in the charters for Crawley (S 827, Lunden herepath), Easton (S695, Lunden weg), and Candover (S 360, Widan herpathe); the latter also mentions Bucgan oran (Bugmore Hill), which is a landmark a little to the south where the Lunway crosses M 42a close to Shroner (ora, 1272).

Christopher Taylor ${ }^{21}$ makes much the same observations about the routes in use to and from Winchester, but without giving reasons.

The North Hampshire Ridgeway follows the crest of a chalk escarpment. Going eastbound its use seems to start near Marten (mere-tün, DB) which lies at the foot of the Chute Causeway (M 43), it climbs to pass above Rivar (yfre 931), Buttermere (mere-on-chalk 863 $\left(12^{\text {th }}\right.$ century) $)$ and Rivar Copse ( $14^{\text {th }}$ century) then over Pilot Hill (Wat oran and Middel oran $909\left(12^{\text {th }}\right.$ century)), and by Ashmansworth (mere, $909\left(12^{\text {th }}\right.$ century)). It is described as a herepath in the Ecchinswell charter, S. 412 . This stretch of ridge-way links M 43 to M 4 (Silchester to Old Sarum).

Near Oxford, the routes over the Berkshire Downs (roughly Wantage to Newbury) and along Knightsbridge Lane (Oxford to Henley) have been described under öra (see vol. 2 pp. $225,227-8$ ). Other routes are highlighted by place-names; part of Akeman Street, M 16b, by Stratford Bridge (c. 1200 (13 ${ }^{\text {th }}$ century)) over the Glyme, and with Ashford Mill (ofer, 1176) with the crossing of the Evenlode. The Roman road M 160, Silchester-Alchester-Towcester, goes by Streatley (c.690 (c. 1200)), Shillingford (c. 1200) where it crosses the Thames, Shotover (ofer, DB) where there is a cross-roads with a route to London, Merton (DB), Stratton Audley (DB), and Water Stratford (DB), and so to Towcester.

A minor Roman road, M 173, Dorchester to Fleet Marston, is marked by Drayton St Leonard (1146) and Draycot (DB), which are both at crossings of the Thame. Another minor road, M163, is thought to run from St Albans through Bedmond (funta, 1331) and Chalfont St Giles (funta, DB) to Hedsor (óra, 1195) where it crosses the Thames en route to Silchester.

The Icknield Way was discussed as far as Kentford under East Anglia. Its next indicative place-name after crossing the Cam, perhaps at Whittlesford (1086), is Fowlmere (mere-onchalk, DB). Shortly after crossing M 22 at Baldock, it reaches the first of a series of ōras and ofers which mark its route to the Thames crossing at Goring and Streatley: Highover Farm (ofer, $13^{\text {th }}$ century) in Hitchin, where there is also Oughton Head ( $\bar{e}$ wiell-tün, 1285), then Buckleshore (óra, 1200) near Whipsnade, Aldbury Nowers (ōra,1447), Chinnor (óra, DB), Lewknor (ōra, 990), Ewelme (̄̄ewielm, DB), and Bixmoor Wood (ōra, 1337). After crossing from Goring to Streatley the track climbs onto the Berkshire Downs, passes Compton (DB), Compton Beauchamp (955 (c.1240)), crosses two Roman roads, and a winterbourne at Draycot Foliat (1197); after crossing the Marlborough Downs it descends steeply to Alton Barnes and Priors ( $\bar{e} w i e l l-t \bar{u}, 825$ (1150)), crosses the Vale of Pewsey and climbs onto Salisbury Plain, passing Imber (mere-on-chalk, DB) at the heart of the waterless stretch. The

21 Taylor, Roads, pp. 99-101. 
next landmark is Long Iver (yfre, 1566) and then Chaldicott's Farm (1448). Ashmore (mereon-chalk, DB) a watering place for travellers on several roads, is followed by views into Compton Abbas (956 (14c.)) and Fontmell Magna (a spring name 871-7 (15c.)). After crossing the Stour the Great Ridgeway again climbs onto chalk hills, passes Ansty (1219), goes close to Alton Pancras ( $\bar{e} w i e l l-t \bar{u} n, 1012)$ and Toller Whelme ( $\bar{e} w i e l m, 1035)$, through Broad Windsor (DB), and thence to the coast.

Hardly any of the Icknield Way/Great Ridgeway is more than a day's journey from an indicative place-name. The type of name varies from the fords in the rather empty,

featureless country in the northeast, through the öra ofer and $\bar{e} w i e l l ~ \hat{e} w i e l m$ names of the Chiltern escarpment, the cumb-tūn and $\bar{e} w i e l l ~ \bar{e} w i e l m$ names of the Berkshire and Dorset Down escarpments, and the meres of the wide expanses of the chalk upland. The emphasis is on water supply and easily-recognisable landmarks: the one a valley, the other a hill. The functional tün type of name is very rare on this prehistoric route.

A recent article by Sarah Harrison ${ }^{22}$ casts doubt on the existence of the Icknield Way as a long-distance prehistoric track, and opines that, referring to the stretch from Wanborough WLT to Princes Risborough BUC, 'The Icknield Way appears to have been at most a medium-range Saxon trackway, perhaps linking significant settlements along the western end of the chalk escarpment'. This runs counter to the place-name evidence. Watts, ${ }^{23}$ following Kitson (unpublished) suggests that Icknield Way means 'way leading to the Iceni', in which case the Way would have to have extended into Norfolk where the Iceni were based. The place-name evidence outlined above suggests that the whole route was in use from the Channel coast to the northwest Norfolk coast. If the ferry across the Wash from Tric LIN, to Holme NFK, was functioning there would have to have been a route leading to and from Holme, and the Icknield Way would have been a suitable one.

\section{j) The Midlands (figs 9.4 and 9.5)}

The Peak District, a limestone upland deeply dissected by river-valleys, has been mined for lead since Roman times. The area is criss-crossed by prehistoric tracks, Roman roads, salt ways and pack trails. ${ }^{24}$ It could be a dangerous area for travellers because the height, over 1,000 feet in places, increases the incidence of days when it is fog-or snow-bound. Although it is well supplied with ofers to use as landmarks, it is difficult to know from which tracks they can usefully be seen without being familiar with the area, and therefore difficult to deduce which tracks might have been important in Anglo-Saxon times. In later centuries travellers sometimes employed guides. However, the Roman roads from Buxton to Littlechester, M 7la, and Buxton to Templeborough near Sheffield, M710b, seem not to have been used, but the Littlechester to Chesterfield M 18d was. A possible Roman road from Chesterfield to Ashbourne, and perhaps Rocester, was called Hereward's Street (c. 1275); it ran through Matlock and Wirksworth, the lead-mining area, and passed close to Ashover (ofer, DB) and Okeover (ofer, 1002). ${ }^{25}$ The Old Portway ${ }^{26}$ ran from Milford near Belper, through Wirksworth to Winster, close to Birchover (ofer, DB) another lead-mining area, and to Alport. Calver (ofer, DB) was on a salt way. ${ }^{27}$

The Mercian kings had their royal palace at Tamworth in the eighth century, whilst Lichfield was an ecclesiastical centre; the latter is well placed for access, with Roman roadsin-use forming a cross roads there, and a Gough/Ogilby route passing through too. Tamworth

${ }^{22}$ Sarah Harrison, 'The Icknield Way: Some Queries' Archaeological Journal, 160 (2003), pp. 1-22.

${ }^{23}$ CDEPN, s.n. Icknield Way.

${ }^{24}$ Dodd and Dodd, Peakland.

${ }^{25}$ PN. DBY, pp. 21-2.

${ }^{26}$ Dodd and Dodd, Peakland, pp. 13-5.

${ }^{27}$ Dodd and Dodd, Peakland, p. 122 
was not so well placed; in fact its road system bears little relation to the Roman roads; only the Portway from Harlaston (ultimately from Burton-on-Trent?) passes an indicative placename: Haselour (ofer, 1242). Being so close to M 1, Tamworth did not really need any such names on its southern approaches.

Lincoln is well-served by Roman roads, four showing place-name evidence that they were in use in Anglo-Saxon times, even if it is a little sparse. The road M 2d, to South Ferriby, is served by Sturton (strêt, DB) but there are no place-names to suggest that the Roman road, $\mathrm{M} 2 \mathrm{e}$, from North Ferriby on the north bank of the Humber, was in use unless Marton in the Forest has been wrongly interpreted by Watts as from ON marr and is really from OE mere; even this would be very sparse evidence. The Roman road, M 27, from Lincoln to the ferry at Tric (Skegness) has a strēt-tün (Great Sturton, DB) on it, and therefore presumably the ferry was operative in some measure too. A branch M 272, off this road led to the coast at Grainthorpe and was partially marked by Collow (Caldecote, DB) and East and West Wykeham (DB). M 2c leading south is considered under roads radiating from London (London-Berwick). The Gough map shows that High Street M 270, was in use, but there are no indicative place-names along it, except Draycote (1212) near Caistor, and even this probably refers to the M 271 climbing up from the river Ancholme. One might have expected some mere names on the chalk upland, but they are absent. M 28 Lincoln - Littleborough Bawtry is well marked, passing through Sturton-by-Stow (DB) and Marton (DB) where it crosses the Trent to Littleborough. One and a half miles north of this crossing was the river port of Knaith (hyth, DB), and 2 miles to the south was Torksey at the junction of the Trent and the Fossdyke, a Roman canal. Torksey is recorded in ASC s.a. 873 when a raiding army took up winter quarters there - it is curious that this strategic point on the Trent was not known as a hÿth. M 28 then goes through Sturton-le-Steeple (strēt-tün, DB), thence to join the Great North Road (as shown on the Gough and Ogilby maps) at Bawtry.

The Fosse Way between Leicester and Lincoln (M 5e, M 5f) has no indicative placenames along it (except a post-DB mōr-tūn), suggesting it was not in use. Leicester was probably accessible using $M 57 b$; Fenny Drayton (DB), although it is primarily connected to the crossing of the Anker by M 1g, might also indicate use of M 57b. Eastwards M 57a passed through Great and Little Stretton (DB), and Drayton (1163) by the crossing of the Welland; thereafter, to the crossing of the Nene, the route is not established with certainty; although it passes through Brigstock (DB) it has no need to cross the Harpers Brook there the brycg is on a side road leading to Grafton Underwood and/or Geddington (Geddington was a well-used stopping place for King Edward I); Drayton Park (12c.) was close to the crossing of the Nene. It is thought that a minor Roman road left M 57a at Medbourne for Wansford near Water Newton; the suggested route is through Caldecott (DB). Three other minor Roman roads mentioned by $\operatorname{Cox}^{28}$ take in significant place-names: Great Casterton to Tixover (ofer, 1104-6); secondly, Empingham through Morcott (1177) to Turtle Bridge, and thirdly, from M 2c through Thistleton to Market Overton (?ofer DB) and within sight of Cold Overton (?ofer, c. 1087, see vol. 2, p.239-40) under Orton and Overton). Cox ${ }^{29}$ mentions a lost Roman road from Six Hills on the Fosse Way through Barrow on Soar, passing Strettonen-le-Field and going to Wall on Watling Street.

\section{k) The West Country (figs 9.1 and 9.6)}

In this area, south of the Mendips and mostly west of Old Sarum, the Roman roads decrease in number while the non-Roman tracks increase as one goes westwards. The countryside in Devon and west Somerset becomes more broken and hilly, and the settlement

\footnotetext{
${ }^{28}$ PN RUT, pp. xx-xxi.

${ }^{29}$ Barrie Cox, A Dictionary of Leicestershire and Rutland Place-Names (EPNS, 2005).
} 
more dispersed. This makes it much more difficult to pick out important routes. There are no longer any straight Roman roads to form the basis of a network; there are fewer large settlements to develop into route centres. The end product visible today is a close network of tiny lanes in the cultivable areas surrounding the main uplands of Dartmoor and Exmoor

In this area, several old routes are conspicuously lacking in any place-names which would indicate their use, and are best dealt with first. The Roman road M $4 b$, from Silchester to Old Sarum, has no place-names along it indicating use; it would not have been an easy route to use because it has long stretches without ponds or streams to supply water. Similarly, that from Winchester to the top of the Chute Causeway, M 43, is almost devoid of indicative place-names, even the Drayton in Barton Stacey (995-1006, c. 14) seems to show that the crossing of the Test has shifted north from the Roman road crossing; this road also crosses long waterless stretches. The Harroway from Farnham across Salisbury Plain as far as its crossing with the Great Ridgeway also lacks the indicative place-names discussed here; it does, however, feature as a herepath between Overton and Andover in a charter of 1033 (S942) and hareweie $1604 .{ }^{30}$ Much of this is chalk country, so water-supply would have been a problem. There are few bournes and there are no mere names indicating man-made pools for water supply; the resulting sparsity of settlements and the shortage of water meant that there was little incentive to use this route if there was a better alternative. The absence of indicator place-names suggests that the Harroway between Farnham and a point near Chicklade did not exist as an important through route in Anglo-Saxon times. Indeed, Christopher Taylor ${ }^{31}$ comments ' None of it has any real appearance of antiquity ...'; that is not to say that parts of the central Harroway were not used as local tracks sometimes. This central portion of the Harroway is paralleled by part of the Ogilby route from London to Land's End (roughly between Basingstoke and Salisbury); this has no indicative place-names either, which suggests that the Ogilby route came into use after the Anglo-Saxon period but before the late seventeenth century. To the east of Farnham, where the route is usually called the Pilgrim's Way, a series of ora names where the Roman roads from London to the south coast crossed it suggests that it was in use into Kent to just beyond Maidstone. To the west, where the Harroway crosses M 46, Badbury to Bath, 2 miles north of East Knoyle there are hints of a route in use - a White Sheet Hill where it descends a steep hill to become Long Lane, then Kingsettle Hill and Hardway (both a hamlet and a road name; no early spellings available), then it passing Compton Pauncefoot (DB) en route for Ilchester.

The route from Charterhouse in the lead-mining area of the Mendips to Old Sarum, M 45, has no indicative place-names along it either - any lead that was mined by the Anglo-Saxons was not taken down to the coast for export as it was in Roman times, but taken elsewhere, either along M 540 through East and West Harptree (herepceth, DB), or along the road skirting the southern foot of the Mendips (see under Gloucester above).

However, some routes were in use. M $4 \mathrm{c}$ and $\mathrm{M} 4 \mathrm{e}$ from Old Sarum via Badbury to Dorchester is marked by Stratford sub Castle (1091) and Stratford Tony (672 (12 ${ }^{\text {th }}$ century)), and Almer (1212, a mere on chalk and valley gravel), producing discontinuous stretches of road-in-use. Beyond Dorchester M $4 \mathrm{f}$ is marked by Compton Valence (DB) and West Compton ( $934\left(17^{\text {th }}\right.$ century) ) taking the route as far as Bridport. The trail is picked up again west of Lyme Regis along a herepath (M 49) going through Colyford (1244), Holyford $\left(1005\left(12^{\text {th }}\right.\right.$ century) ), Harepath Farm $\left(1005\left(12^{\text {th }}\right.\right.$ century $\left.)\right)$, Sidford (1283), Harpford (herepcethford, 1167) and so to Exeter.

Travellers could use M 5a and M 4f to go from Ilchester to Exeter; they would have to bypass Compton Durville (DB), go through Over Stratton (DB) and Street (DB); turning west

\footnotetext{
${ }^{30}$ J.E.B. Gover, The Place-Names of Hampshire (unpublished typescript; a copy is held by EPNS at Nottingham, c. 1961), p. 6

${ }^{31}$ Taylor, Roads, p. 183.
} 
on M 4f, they would pass Nower Farm (1384) and near Honiton, where tracks lead up to plateau-top routes, they would see Gobsore (öra, 1238); passing by Straightgate Farm (stri $\overline{\mathcal{k}^{\prime}}$, $1061)$ and Strete Raleigh (DB) they would reach Exeter. Beyond Exeter travellers would be reliant on non-Roman routes. From among the maze of little lanes it is possible to suggest some old through routes. There is an Ogilby route (plate 27) which passes feeder tracks called Gappah ( pceth, DB) and Whiteway Barton (DB) and goes by Hartford (herepeethford, c. 1200) and Rora (öra, 1230). After a long gap the road passes Compton Giffard (DB) on the outskirts of Plymouth.

In north Devon and Somerset, several ridgeways have indicative names by them (see vol. 2, p. 231-2), mostly names indicating tracks: weg, path, stig or öra. The first three indicate routes of lesser importance, while the oras are there to guide travellers when the choice of track is not obvious. 1t seems likely that there was a route from Combwich on the Parrett estuary over the Quantocks, indicated by Nether Stowey (weg DB) and Over Stowey (DB), and Halsway (c. 1080) to the Brendon Hills ridgeway. It then goes westwards to Exford (DB) and Moles Chamber where a route from the southeast joins it. From Moles Chamber the route made its way past Loxhore (öra, DB) and Yarner Wood (öra, 1469) to Pilton, an Alfredian burh, and the estuary of the Taw and Torridge, a safe haven. A small ora-marked haven on the north Somerset coast, Porlock, linked into the system up a small, steep track; thence the traveller could access the Brendon Hills ridgeway, which would lead to the abovementioned crossing of the Quantocks, or use a route closer to the coast, passing Bidwell (1279) and rounding the north of the Quantocks to reach Combwich. Bidwell would also serve any traveller using the route along the top of the Quantocks.

The routeway network beyond Exeter is thus imperfectly known for a variety of reasons: lack of Roman penetration, a settlement pattern and therefore road network different from midland England, and a lack of a detailed study of Somerset place-names.

\section{Water-borne Transport}

Having discussed the land-based routes, those used by water-borne traffic now need to be considered, ${ }^{32}$ (see map: fig. 6.16). The water routes differ from the land routes in several ways; in the first place there are many fewer indicative place-names both in terms of variety and of overall numbers; secondly, there are two spheres of water transport: the river routes and the sea routes; thirdly, the water routes rarely make a network like the roads do, but consist of lines of penetration from the coast to places inland. There are two additional factors, both problems which make the identification of water routes more difficult. The first is the question of the nature of the boats used by the Anglo-Saxons, and the second is the near impossibility of telling from an O.S. map whether a river is navigable or not along any particular stretch. It seems quite clear from the position of many of the $\bar{e} a$-tüns that quite small, gently flowing, lowland streams were pressed into service. For instance, the Upper Thames between Lechlade and Cricklade could take a punt-like boat quite easily but not anything needing as much width as a rowing boat. A punt is large enough to carry a useful amount of cargo, and so a river capable of carrying punt traffic would be worth keeping open and navigable, hence the function of the $\bar{e} a-t \bar{u} n$ s. Some rivers have such tight meanders that a full-length punt could be very difficult to manage - a smaller version would be needed. At what stage does a punt become so short as to be uneconomic? In some western counties coracles are, or were until recently, in use. I have seen them on the Teme (WOR). Is a river that is only capable of taking a coracle still deemed navigable and worth keeping open?

\footnotetext{
${ }^{32}$ See the last section of chapter 6 for an analysis of the evidence provided by the water-transport place-names. John Blair's map (fig. 5 in Blair, Waterways, p. 18), derived from a variety of indicators showing the waterways in use in the early medieval period, reveals a similar pattern to that shown by the place-name evidence.
} 
As stated, it is not possible to tell from an O.S. map whether a river is navigable or not. There are substantial rivers in the Yorkshire Dales and in Devon, but they may be rockfloored and full of little rapids and rough water, or prone to the effects of heavy rainfall or drought making any form of boating dangerous. Any assessment of navigability using maps is therefore very speculative. Fortunately Edwards ${ }^{33}$ has noted the navigability of numerous English rivers and this information forms the basis of the following observations. He gives the present head of navigation of rivers but this could be a weir, a low bridge, a tidal sluice or some feature not present in early medieval times. Equally, one should remember that the river channels themselves may have changed over the centuries. The stretches listed by Edwards would be suitable for small cruisers today. In addition, he gives a list of rivers which are canoeable, but no indication of how far up-stream they can be used. Thus the data needed for assessing the extent to which the rivers of England were in use in early medieval times is incomplete, and so the waterways-in-use described here do not make a wholly reliable corpus.

Sea-borne traffic would have been along the English coast or cross-channel. The position of three ports and of two DB hyths on the south coast suggest that the majority of the international contacts were across the English Channel from Kent around to Dorset across to Frisia, Rhine-mouth and northern France. In England north of the Deben and Alde estuaries (just north of Ipswich where the landfall is marked by two coastal oras) there are no ports or DB hy ths to suggest traffic across the North Sea (but see Humber below). To the west of Portland there are signs of coastal traffic or traffic from Brittany making landfall around the South-West Peninsula, near Exeter and in the Salcombe estuary. The south side of the Bristol Channel was also busy with shipping which, having rounded Land's End, has left a trail of place-name clues such as the óras on the north Devon and Somerset coasts (Chivenor, Kitnor, Yearnor and Capenore), the two ports at Porlock and Portishead/Portbury, and the (ge)wced, anomalously far west for an otherwise eastern term, at Wadebridge. Some of the traffic would have crossed the Bristol Channel to South Wales visible across the water, and some may have been bound for Ireland. In the North-West (LNC, CMB) the contacts would have been across the Irish Sea to the Isle of Man and Ireland, dominated by the Norwegian Vikings, the indicative names being the stceth/stoth ones.

Seaborne traffic from Frisia and the Rhineland could have made landfall at Creeksea or Pudsey in Essex, but these two hy ths do not connect with the road system. It was probably much more satisfactory to come up the Thames estuary to one of the numerous hyths near London: Erith, Greenhithe, Stepney, Lambeth, Chelsea, or Putney. These could be seen as the last of the coastal hy $\bar{y}$ ths of South-East England or as the first of the Thames-side hyths. Judging by the place-names, the Thames was the busiest river; it had the great advantages of reaching the sea close to the Continent so that cross-channel journeys were short, and of leading into the heart of southern England. It was of sufficient importance for many hyths to develop, several where Roman roads crossed the river such as at Hythe and Glanty, and in Oxford, or on other old routes as at Maidenhead and Bolney. Efforts were made to keep the Thames navigable up to Cricklade, as there are four $\bar{e} a-t \bar{u} n s$ on these higher reaches. This would enable goods or people to access the Roman road system leading to the west midlands.

The other important river system accessed from the east is the Humber - not so convenient for Frisia or France, but good for those crossing the North Sea from Denmark or Scandinavia. The most well-marked route was up the Trent; there are two ON names, Flixborough Stather and Burton Stather, near the mouth. Further upstream the names

\footnotetext{
${ }^{33}$ L.A. Edwards, Inland Waterways of Great Britain (St Ives, 1985).
} 
Stockwith, Walkerith and Knaith relate to the important link between Lincoln and York using the Foss Dyke-Trent-Bykers Dyke-Don-Ouse route described in Chapter 6.

The Severn and Wye have no hyth or stoeth names along them. It is only in their upper reaches that any waterway-in-use terms occur - the é a-tun names. These suggest the headwaters of the Severn were in use, as was its tributary the Teme. The upper Wye and its tributary the Lugg also have éa-tün names. The place-names do not tell us if the lower Wye and lower Severn were in use, but the Severn is navigable up to Welshpool, so it very probably was used, although one would have to be careful of the strong currents and the bore. The Wye is navigable up to Hay, but the stretch through the limestone gorges between Ross and Chepstow can be dangerous, and only small craft are advised to use it above Tintern; conditions are better round Hereford.

The Fens have been so drastically altered by drainage and reclamation since early medieval times that it is hard to envisage conditions as they were then - an area of sluggish rivers winding through marshland with occasional islands of higher ground rising above it. It was well nigh impossible to travel on foot through the peaty, south-western Fens, although the Romans did manage to build a road through the silt Fens to the north-east. The beginning of a route-way network in the Fens was emerging by the end of the early medieval period. Three hyths (Swavesey, Lakenheath and Otringhithe) round the fenland edge are recorded in DB, but only Otringhithe is close to an old route (M 332). These place-names suggest that the Great Ouse and Little Ouse were used - at least in part. Whaplode, the only DB lād, provided a link to the Wash, but was unrelated to these hÿths. There are no e $a$-tüns in the Fens. In the two centuries following the Conquest many more examples of $h \bar{y} t h$ and $l \bar{a} d$ appear, reflecting the work of the monastic houses - their need for better drainage, and easier more frequent access to the islands whose resources they were exploiting. The route-way network that appears in the Fens, is to some extent a localised one. However, the increasing number of $h \bar{y} t h$ s round the fen-edge (Setchey, Methwold Hythe, Clayhithe) provided additional points of access to the waterways. By using Car Dyke (the Roman canal) as well as the Little Ouse, Great Ouse, Nene and Welland, it was possible to go from north-western Suffolk to southern Lincolnshire by water. Stretches of artificial waterways were valuable for linking rivers to firm ground through the marshland, especially to the north-east of Cambridge using Bottisham, Swaffham Bulbeck and Reach Lodes. Although the fenlands in the vicinity of Peterborough are devoid of water-transport-indicative place-names several hyths are recorded in Anglo-Saxon charters of the area, for instance, Dichyde, Sudhythe, Nordhythe and Farresheafde in Yaxley and Farcet (S 596), by the old course of the Nene, three or four miles from the Roman road network; there is likely to have been plenty of water-borne traffic in this part of the Fens too.

The situation in the Somerset Levels resembled that of the Fens: marshland with sluggish rivers, and little in the way of place-names to indicate use in the Anglo-Saxon period; only Bleadney $(h \bar{y} t h)$ on the Axe, situated where the river broke through the ridge leading to Wedmore. Here too, monastic houses, especially Glastonbury, were busy with schemes to improve drainage and navigation, so that in the post-Conquest period a hÿth, two läds and two directional ofers appear in connection with the river Axe serving the northern part of the Levels. Hythe served Cheddar and could connect up with the Mendip-foot route; Northload (in Theale) linked Wedmore to the Axe, and another Northload linked Glastonbury to the same river. A track along a causeway to Street linked Glastonbury to the Roman road system. South of the Polden Hills, the river Parrett and its tributaries were busy thoroughfares; there was a stceth on the Parrett to serve the big Curry estate; two lāds, Curload and Cogload, improved access to the Tone through the marshes of Curry Moor; Long Load and Little Load were on the (Ilchester) Yeo at a point where the flood-plain narrowed, and only a short lâd was needed to link river and firm ground; the Fosse Way was four miles to the south. 
Directional ofers, low hills beside the rivers offering landing sites uncomplicated by marsh, occur in Bridgwater, Langport and Ilchester - all of which had good road links

The other hȳths and $\bar{e} a-t \bar{u} n \mathrm{~s}$ are much more isolated; they are on smaller rivers, with shorter navigable stretches. The Adur is an interesting case as the position of the landing place seems to have shifted upstream from Portslade to Heath Barn even though the presence of Eaton just upstream suggests that there were silting or other navigational problems on the river. There was ready access to the road system nearby (M 140). However the bridging of the Adur at Bramber after the Conquest must have rendered the hyth no longer useful or viable. Others such as Hive and the lost New Hythe YOE, served only local areas and are not really part of a country-wide network at all.

The extent to which the waterways and the road network interconnect needs to be considered. Was there an 'integrated transport system'? Firstly, in the pre-Conquest period how far are the coastal ports, hy ths and stoeths evidenced by DB linked to the network which the place-names suggest was in use at that time? When the last few miles of a route to a landing place lacks any of the indicative place-names described here, it must be borne in mind that the destination itself may be the last link in the chain of names. Routes-in-use that on the map appear to stop just short of a landing place did not necessarily do so in practice. Place such as Portsmouth, Portland and Portishead/ Portbury can thus be presumed to tie into the network. Other pre-Conquest links between coastal landing places and the road system are at Hythe KNT, Portlemouth DEV, and probably at Porlock SOM. Those that do not appear to link into the road system are Creeksea and Pudsey ESX, Huyton and Toxteth LNC.

The post-Conquest coastal landing places link into the roads-in-use network at Old Heath and Hythe ESX, Heath Barn on the Adur to M 140, and Hythe HMP, to M 423. Rather more examples do not link into the network of roads-in-use (though doubtless they would have had local roads - Bulverhythe, the haven for the people of Hastings, must have been linked to that settlement for instance); they are Bulverhythe SSX, Prattshide and Hyde DEV, Hyton CMB, Todderstaffe and Hubbersty LNC; although the last two are close to Roman roads, those roads were apparently not in use.

The links between inland hy ths and stceths/stoths to roads-in-use in the pre-Conquest period are good along the Thames. The hyths in the London area were close to several roadsin-use; Hythe and Glanty SUR, were close to the crossing of M $4 \mathrm{a}$ over the Thames at Staines; Bolney was close to the end of Knightsbridge Lane and the Roman road from Dorchester to Henley; Hidden BRK, was within reach of M 41 and M 53. Elsewhere Knaith LIN, was close to the crossing of M 28 over the Trent.

Some inland DB hyths and staths/stoths were not near roads-in-use. These are Rackheath NFK, Hive YOE, Huyton LNC, Stafford STF, and Birstwith YOW. Those in the heart of the marshlands, having a slightly different function, would not be near roads, but those on the margins might have been a link between the marshland communities and those of the surrounding, better-drained land. Bleadney SOM could be seen in this light, although the place-name evidence for the ridge road being in use is poor. Swavesey CAM, could link the Fenland communities with the M 24 Cambridge to Godmanchester road, and Otringhithe was linked to the Icknield Way by a short stretch of M 332.

The post-DB hyths and steeths/stoths were rarely linked to the early medieval road system. Possibly by the time they became important there were other routes developing not marked by place-names. Those that did link in were Heath Croft and Hithe Bridge OXF with a Gough route; Riverhead and New Hythe KNT, possibly with the Pilgrims' Way, and Hythe SOM with the Mendip-foot route. Stockwith and Walkerith were associated with the TrentOuse waterway. New Hythe YOE, before it got washed away, served Holderness.

The siting of the $\bar{e} a-t \bar{u} n$ s, nearly all of them pre-Conquest, suggests that in many cases a waterway was being kept open as far upstream as necessary to give access to a Roman road 
or other old route. On the Upper Thames, Eaton Hastings lies between the salt routes which reach the Thames at Bampton and Lechlade. A little further upstream, Castle Eaton and Water Eaton kept the Thames open as far as Cricklade, where M 41 was in use. Woodeaton and Water Eaton OXF kept the Cherwell open as far as Islip, where an Ogilby route (London-Worcester) crossed the Ray and then the Cherwell; parts of this route seem to have been in use pre-Conquest, but not this stretch

A series of $\bar{e} a-t \bar{u} n$ s occurs close to Watling Street and its extension to Chester, implying that there were trans-shipment points nearby: where Watling Street crossed the Ouzel near Water Eaton BDF; where it crossed the Anker near Nuneaton WAR; where it crossed the Penk near Water Eaton STF, and where the Chester branch crossed the Dee at Eaton Hall $\mathrm{CHE}$.

The other $\bar{e} a-t \bar{u} n s$ that imply a river is being kept open to give access to a road-in-use are Eaton Mascott on the Cound Brook SHR; Eaton under Heywood on the Eaton Brook SHR; Eaton NFK on the Heacham River, and Eaton near Norwich on the Yare. The Idle was kept open upstream as far as the crossing with a Gough/Ogilby route, by Eaton NTT. Eaton Socon on the Ouse is a less certain example.

Some $\bar{e} a-t \bar{u} n$ s do not imply this connection as, although they may be close to a Roman road, there are no place-names to suggest it was a road-in-use; the ones in Herefordshire are examples. The $\bar{e} a-t \bar{u} n s$ on the Severn and its tributaries are in the vicinity of Wroxeter and less closely connected to the road network; perhaps they were more concerned with enabling goods to reach the Severn.

If the post-DB terms are considered then the directional ofers must be added to the hyths and $\bar{e} a-t \bar{u} n s$. The area most affected encompasses the Somerset Levels and Dorset, where other significant names appear on the Axe and nearby streams; a hyth on the Yeo serving Cheddar and linking into the Mendip-foot route, and a Southover in Wells on the banks of a small tributary. The Parrett seems to have been a busy waterway; there was an'Eastover' and a 'Westover' in Bridgewater; firm landing places either side of the river. Another Eastover and Westover at Langport lay either side of the Parrett, where there was an important crossing of the river used by Old Way running from Somerton to the Blackdowns ridgeway. Northover, lying on the bank of (another) Yeo near Ilchester, provided a firm landing place which lay athwart the Fosse Way, M 5. Several läds had come into being, linking rivers to firm ground in places where flooding and marshes were a problem; Cogload and Curload on the Tone; Long and Little Load on the Yeo. The increase in activity must have been linked to the drainage and river works implemented by the monastic communities flourishing in the area.

Elsewhere in the south of England the directional ofers, all post-DB, hint at smaller rivers being used for short distances inland; Westover in Wootton DOR was close to the point where M 49 and another minor Roman road a little closer to the farm, crossed the Char; Southover DOR is close to the point where M 4 crosses the Piddle.

As time passed, newer routes were coming into being - those that would eventually feature on the Gough and Ogilby maps; for instance, the development of the Gough route from London to Bath/Bristol, which crossed the Thames at Maidenhead, was probably responsible for the increased activity at the landing-place there and the change in name from Elintone (DB) to Maidenhead (1245), but this is moving beyond the early medieval period and beyond the scope of this study. It is more appropriate to see whether the place-name data assembled can yield other useful information about the routes, and whether there is any evidence from other sources that could support the findings presented here. These possibilities are explored in the next chapter. 


\section{CHAPTER 10}

\section{FURTHER CONSIDERATIONS: CHRONOLOGY AND SUPPORTING EVIDENCE}

\section{CHRONOLOGICAL ASPECTS}

The preceding part of the thesis has been concerned with the spatial distribution of certain corpora of place-names and the way in which they can suggest what routes were in use in the early medieval period. However, this is a long time-span - some six and a half centuries during which time the Roman institutions disappeared, the Angles, Saxons and Jutes established their first settlements, the various tribal groups evolved into kingdoms, Christianity spread, the Viking invasions and settlement occurred, towns developed, the open-field system evolved and eventually England emerged as one kingdom. During this long period of upheavals, change and evolution the route-way network would also have grown and developed into a national network - that is to say, routes developed that went from one end of the kingdom to the other: place-names along them arose that were sufficiently consistently applied from north to south, east to west, to enable any traveller to find his way and to know what to expect at named points along his route. That is not to say that there were not recognised long-distance routes still surviving and in use from pre-AngloSaxon times (the Icknield/Ridgeway and Fosse Way, for example) but it seems more likely that in the earliest Anglo-Saxon period they were used more for local journeys around the new settlements than for long-distance travel exploring a new land. Is it possible to trace the evolution of the route-way network? Certainly there are possibilities but there are also many problems.

1) Evidence derived from the dates at which the indicative place-names are first evidenced

One method is to list together all the place-names that are first evidenced in particular time periods and to compare the results. The time periods chosen (pre 850, 850-949, 950-999, $1000-1085,1086$, post 1086) were such that the numbers of places in each of the four earlier periods were not too dissimilar nor too small. The selection of place-names to include also posed problems. In an attempt to get as even a coverage over England as reasonably possible, only settlement names were used for the reasons explained in chapter 2 . Therefore, in general, place-names that did not apply to settlements on modern maps were excluded unless they were known to have referred to settlements in the past: Compton Wood SSX, was the site of a DB estate and was therefore included, whereas The Nower SRY, a hill name, was not. Also excluded were certain 'lost' names where it was not clear whether the name was referring to a settlement or not. This was especially applicable to non-habitative place-names where it could easily have resulted in an over-estimate of the number of such settlements; with the tün and cot names some habitation is implied in the very name. It was important that the balance between the non-habitative and habitative names was as fair as possible. The problem with using a modern map to identify whether a name referred to a settlement or not is that it does not necessarily reflect the state of affairs at the time when the name was coined or when the first surviving written reference was made to it. One can only hope that with a large number of names the errors balance one another out.

It is not known when most of the places first acquired the names that have come down to us. Their names may have changed several times over the Anglo-Saxon centuries. Some probably did while other places may have kept their early, original names even if no record of this survives. A further source of error in the list of names comes from examples derived from Anglo-Saxon charters, some of which were spurious. The exercise has therefore been done twice, once using the purported date of the charter whether or not it was authentic, and again using only the dates of charters that are regarded as authentic (according to the 
comments in Sawyer). ${ }^{1}$ Neither way is very satisfactory, but there is some interest in comparing the two sets of data

Figs 10.1 and 10.2 show these statistics incorporating these provisos as far as possible. Fig. 10.1 uses the purported dates of the charters regardless of whether they were spurious or not. Fig. 10.2 uses only the dates of charters that are regarded as authentic. The main effect is to reduce the numbers of instances in the earlier centuries (from 40 to 12 in the pre-850 category and from 34 to 21 in the 850-949 category) and increase the numbers in the DB and post-DB categories. Occasionally this results in a name being so late-recorded that it has to be removed from the corpus entirely. Although the amount of early evidence of the existence of names has been reduced the relationship between the various categories of name has been maintained and if the corpus is treated statistically some trends can be identified.

Figs 10.1 and 10.2 show the same categories of road names, crossing places, facilities, miscellaneous terms and signposts as before but omit place-name elements that, although discussed in earlier chapters, were shown not to bear a close relationship to major routeways. It is worth noting the large number of oras that appear after 1086, enough to distort the percentages of other indicative place-names in the post-DB column. Had the non-settlement $\bar{o}$ ras been included the distortion would have been much worse. Since ōra was originally used for naming landforms one cannot be sure when an öra name came to be used of an óra settlement, unlike, say, the functional $t \bar{n}$ n settlements where there must have been a settlement at the time of naming. The same observation could be applied to all the nonhabitative names, but they occur in smaller numbers and therefore cause less distortion. However, in spite of all these provisos certain trends are evident: firstly, regarding the types of features (routes, water supply, facilities, signposts etc.) which are most evidenced at particular periods, and secondly, in the changing proportions of the 'element $+t \bar{u} n$ ' category.

The table: fig. 10.1 (and fig. 10.2 is similar in concept) shows for each time period: firstly, the number of examples of each place-name type first recorded in that period (e.g. in the pre850 period there are no examples of strät-t $\bar{u} n$ but five examples of other-strāts); secondly, the percentage of each place-name type out of all the place-name types first recorded in that period (e.g. other-strēets make up $12.2 \%$ of the 41 place-names recorded in the pre- 850 period, $9.4 \%$ of the 32 place-names recorded in the $950-999$ period, $4.7 \%$ of the 337 placenames recorded in 1086); thirdly, the number of tüns newly recorded in each period is also noted; fourthly, for the five later periods the cumulative totals for each place-name type (e.g. eight other-strēts by the end of $950-999$, and 30 by 1086); fifthly, the cumulative percentages are given (e.g. other-strēets make up $9.2 \%$ of all the 152 place-names recorded by 1086). As more place-name types occur in the 1086 and post-1086 periods than in the earlier periods, one would expect the cumulative percentages to decrease for most placename types, especially those recorded pre-850, other things being equal. Where the trend does not show a slight decrease there is usually a reason.

The changing incidence of $t \bar{u} n$ over time shows up. There are only four functional $t \bar{u}$ s and three other indicative but probably non-functional $t \bar{u} n$ in the pre-850 period. Between 850 and 949 there are nine new tüns: the first strōt-tüns, mere-tūns, cumb-tūns and gräefe-tūns appear; the trend continues in the 950-999 (20 new tüns) and 1000-DB (13) periods. In 1086, and nearly all from DB entries, there is a big increase in numbers of strēet-tüns (28), meretūns (18), mōr-tūns (28), mersc-tūns (23), drceg-tüns (16) and cumb-tüns (25) (138 in all), and again in the post-DB period (92). If the percentage of $t \bar{u} n$ s compared to all the new names appearing is considered the numbers are less dramatic, rising from $17.1 \%$ in pre- 850 to $26.5 \%$ in $850-949$. The high figure of $62.5 \%$ in the $950-999$ period is partly due to the distortion likely to occur on account of the smallness of the sample, but nevertheless suggests

\footnotetext{
${ }^{1}$ P.H. Sawyer, Anglo-Saxon Charters: An annotated List and bibliography (London, 1968).
} 
that this was a time when many functional tün names were being coined - or at least recorded for the first time. There is a smaller surge in numbers in 1086 when most of the new names recorded are those of DB estates and therefore of relatively important places $(43.9 \%)$. PostDB the percentage drops back to $26.1 \%$, reflecting the large numbers of minor names appearing in the records, especially the cots, byden-welle and yet more oras to dilute the sample.

The cumulative percentages of $t \bar{u}$ shows a steadier rise from $17.1 \%$ pre-850 to $21.3 \%$ in $850-949$, when the functional $t \bar{u}$ s begin to appear, and to $33.6 \%$ in $950-999$ as this process continues. The percentage of tüns in all name types rises again in 1086 to $40.3 \%$ and evens off at $36.9 \%$ post-DB. This suggests that the period in which functional tüns were coming into being began a little before 850 and became particularly active in the late ninth and tenth centuries. ${ }^{2}$ The same trends are evident in fig. 10.2 when only the authentic charters are used

The appearance of large numbers of tüns in the records during the late ninth and in the tenth century agrees well with the impression that scholars already had that $t \bar{u} n$ was a term that only became widely used towards the end of the Anglo-Saxon period. In particular, the work of Barrie Cox in 'The Place-Names of the Earliest English Records'3 showed that it was rarely used before his cut-off date of 731. He says ( $p$ 63) 'place-names in tün are amongst the most common in England. That so few appear here indicates that they belong, by and large, to the period after about 730'. Nevertheless there are two tūn names, in his list of five, that appear to be early examples of functional tüns: Acton Beauchamp HRE, in a charter of 718 (for 727?) (S85) and Wootton Wawen WAR, in a charter of 716-37 (S 94), presumably both concerned with working wood in some way. Refering to fig. 10.1 the earliest (pre-850) functional tüns among the indicative place-names are two mōr-tūns, one mersc-tūn, one draeg-tūn (and two denu-tüns if they be considered functional). By 850-949 two strütt-tūns and a mere-tūn have made an appearance, which, considering their probable function with respect to supplying travellers, indicates that some sort of 'organisation' of the route-way network and its nomenclature is beginning to emerge. It still does not explain whether the 'organisation' was imposed from above or whether it evolved from below. It does seem, that from 850 or a little before, large numbers of functional tün names were appearing beside route-ways, and that by 1086 or soon after they reached their greatest relative importance. If only authentic charters are used (fig. 10.2) the increasing use of functional $t \bar{u} n$ s is apparent not in the 850-949 period but in the $950-1000$ period.

A few name types decrease in relative importance even though their total numbers continue to increase slowly. By 1086 herepceth and herepcethford, geläd, $\bar{a} w i e l l, \bar{e} w i e l m$ and funta, and wic-häm are all less important. Although these terms made a good showing early on, they inevitably declined in relative importance as other name types entered the corpus.

Cox also notes that cot does not appear in the records by 731 , partly because they are too insignificant to appear in charters. This is borne out by the almost complete absence of cot in the pre-1086 indicative place-names (there is one mör-cot in 1065 (14c.)). In 1086 there are 27 cots and post-DB 50 more appear. They seem to refer to settlements with particular functions or attributes: this suggests that there are a few categories of functional cots: mōrcot, drag-cot and calde-cot. ${ }^{4}$ This is a further step in the development of the nomenclature of

${ }^{2}$ A study by Thomas Pickles 'Biscopes-tün, muneca-tūn and prēosta-tūn: dating, significance and distribution', in The Church in English Place-Names, ed. Eleanor Quinton (Nottingham, 2009), pp 39-107, shows that these are hardly represented in place-names recorded before DB, but in considerable numbers from DB on.

3 Cox, Place-Names, p.12-66.

${ }^{4}$ Among the large numbers of cot names Dyer has identified another group - 'a sizable minority which are close to towns'. Doubtless a close study of cot would reveal other categories linked to particular activities. Dyer, Towns, pp. 91-106. 
settlements on route-ways showing it to be increasingly organised in the late Anglo-Saxon period.

Given that cün makes a relatively poor showing in the first two periods what were the important indicative place-names for travellers then? Fig. 10.1 shows that three groups stand out in the pre-850 period: firstly 'strēt - element-other-than-tün-or-ford', herepath and herepathford describing the nature of the road - the one paved, the other an obvious and substantial route if it was fit for an 'army' to use; secondly, springs ( $\bar{e} w i e l l$ and $\bar{e} w i e l m$ ) and ponds (mere-on-chalk) demonstrate the importance of water supply to travellers, and thirdly the signpost terms, especially ora, to help travellers find their way - the sort of names typical of a route pre-dating the coming of the Anglo-Saxons such as the Icknield Way. At this stage there are very few names describing any man-made aids to the traveller - two bridges, one possibly of Roman origin, and the first of the droeg-tüns. In the second period, 850-950, the same importance of roads, water supply and way-finding is apparent; funta and wīc-häm have joined the list, both names describing Roman features in the landscape and likely to be early coinages; their appearance in the records in this period rather than earlier is probably a matter of chance survival of records. Ora maintains its importance; terms for crossing places appear more frequently.

It is from 950 on that the terms describing settlements offering facilities for travellers become frequent: the strōt-tüns and mere-tüns - halting places: the mör-tüns (and cots) and a mersc-tün offering fodder: the draeg-tūns (and cots) offering assistance: the gräefe-tüns providing return, money-making loads, often to Droitwich: the cumb-tüns and denu-tüns usefully recognisable landmarks but of unknown function - if any.

A few other terms make a comparatively late appearance. Major wegs with their implied warning to carters only appear in the eleventh century. Gewaed, a difficult crossing, is equally late. Byden-welle understandably makes a late appearance since it refers to so minor a feature that it was unlikely to creep into any early, surviving records as a settlement with that name, although it occurs in charter boundaries. Calde-cots, small and not very desirable places, make their first appearance as late as 1086.

It is, then, possible to identify trends in the development of a route-way system using dates of first evidence of place-names over the centuries - the development not so much of the number of routes in the network, but in the provision and naming of the facilities offered to the travellers using those routes, that provision starting in a small way before 850 but gathering momentum in the tenth century, a period coinciding with the conquest by Wessex of the Danelaw and the formation of the Kingdom of England. At this time, with England united and with more peaceful conditions prevailing, when the economy could flourish and with it trade and travel, and so route-way developments were more likely to take place than in periods of unrest and warfare, which occurred particularly during the Viking raids and subsequent settlement.

2) Evidence derived from the routes shown on the Gough map

A second way of investigating the development of the routeway network is to use the Gough map, because it might be possible to identify some changes by comparing that indicated by place-names in the early medieval period with that shown on the Gough map of c. 1360 , by working on the hypothesis that Gough routes with indicative place-names beside them were in use in the early medieval period whereas those without came to importance at a later time. This is applicable to the longer Gough routes, but not to the short local ones such as those in Lincolnshire.

Roads can go out of use, remain in use or come into use.

A road will only survive as long as it is used - if it leads where people want to go. A disused road will soon become overgrown with an impenetrable tangle of vegetation. Better made roads will take longer to disappear - the aggers of Roman roads may persist for 
centuries after the Roman road itself has become disused or robbed of its stone. The road may cease to be an important thoroughfare but survive as a farm track as does Knightsbridge Lane between Standhill and Clare Hill (OXF).

A road may stay in use. Great numbers of tracks and roads have remained in use for many centuries, at least partly because it can be difficult to change the route, because of ownership rights over adjacent land, or because of the physical problems where the road is in a deep-cut hollow way or is bounded by stone walls or massive hedgebanks. It is easier to maintain the status quo than to change it.

New routes may be needed and a road 'appears' to fulfil this need - medieval roads are said to have 'made and maintained themselves'. more intensive use of a series of footpaths rather than being an entirely new route. The reasons for needing a new route are important in this context; they include physical factors such as coastal change and human factors such as political events and urban growth. They are discussed in section 3 below.

A comparison of the routes on the Gough map (1360) with those identified by the indicative place-names produces examples that illustrate five possible scenarios:

i) Gough routes along Roman roads which have indicative place-names, implying a Gough/Roman road in use.

ii) Gough routes along Roman roads without indicative place names, implying that the Roman road was not in use (or at least not of importance) in the Anglo-Saxon period, but came into use/importance post-Conquest and before 1360 .

iii) Gough routes along non-Roman roads, but having indicative place-names, implying that a non- Roman road existed and was in use in pre-Conquest times.

iv) Gough routes along non-Roman roads without indicative place-names implying that the route came into use (or importance) post-Conquest but pre-1360.

v) Routes, usually long ones, which are a rapidly changing mixture of these categories.

Examples of category i)

Brough to Penrith, M5 (part of the London to Penrith route) ${ }^{6}$

Bristol to Droitwich. S3 (part of the Bristol to Grantham route)

Droitwich to Derby, S3a (part of the Droitwich to Doncaster route)

Southampton to Arundel, S1 (part of the Southampton to Canterbury) only slight evidence Examples of category ii)

Wigan to Lancaster, M4 (part of the London to Carlisle western route via Lichfield)

Ware to Huntington M5 (part of the London to Carlisle eastern route via Doncaster)

Wansford to Newark M5, intermittently (part of the London to Penrith route)

Boroughbridge to Brough M5, intermittently (part of the London to Penrith route)

Examples of category iii)

London to Sherborne, M1 (part of the London to Camelford route)

High Wycombe to Oxford, M3, short stretch (London to St David's via Brecon)

Daventry to Lichfield, M4 (part of the London to Carlisle route)

Newark to Pontefract, M5 (part of the London to Penrith route)

Examples of category iv)

Oxford to Gloucester, M3 (part of the London to St David's route via Brecon)

Oxford to Bristol, M3a (the Oxford to Bristol route)

Doncaster to Kendal, M5b (the Doncaster to Kendal route)

Cambridge to Norwich, M5a (part of the Ware to Norwich route)

Arundel to Appledore, S1 (part of the Southampton to Canterbury route)

\footnotetext{
${ }^{5}$ Hindle, Roads and Tracks, p. 41

${ }^{6} \mathrm{M}$ is 'main', $\mathrm{S}$ is 'secondary, $\mathrm{L}$ is 'local'. See Millea, Gough, pp. 85-6, or Hindle, Medieval

Roads, pp. 31-4.
} 
Droitwich to Grantham, S3 (part of the Bristol to Grantham route)

Worcester to Liverpool, S3b, mostly (the Worcester to Liverpool route)

Richmond to Sedburgh, S6 (part of the Richmond to Kirkby Lonsdale route)

Examples of category v)

London to Marlborough, M2, patchily in use (part of the London to Bristol route)

Gloucester to Brecon, M3, patchily in use (part of the London to St David's route)

It is therefore possible to suggest when a few roads have come into use by identifying nonRoman Gough routes with indicative place-names as having developed pre-Conquest, and to suggest which non-Roman Gough routes became important between the Conquest and the time when the Gough map was complied, the most important being the two leading west from London to Bristol and to Oxford. This is not to suggest that the latter routes did not exist earlier as tracks, but that they were not part of the long distance network of important routes. Other routes not shown on the Gough map could equally well have developed into important routeways during the early medieval period: there are many causes of such developments discussed below.

3) Possible changes in the routeway network resulting from events and developments during the early medieval centuries

Many reasons could be suggested why roads might fall into or out of use. They could be illustrated with numerous examples old and new, but, because the evidence is largely documentary, little of it refers to the pre-Conquest period, so the discussion is brief.

They can be considered under the following headings.

a) Physical changes to the landscape

These mostly apply to coastal landing places and could affect the roads that link them to the routeway network.

River mouths can silt up so that landing places are no longer accessible, e.g. Old Heath and Hythe near Colchester (see vol.2 p. 207-8) here the effect on road links was minimal.

Erosion can destroy havens and landing places, e.g. New Hythe YER (see vol.2 p.212-3) its disappearance would only have affected local roads in Holderness.

b) Bridge collapse and bridge-building

Some of the bridges built by the Romans survived into the early medieval period: Rochester Bridge is a notable example.

A bridge which collapsed during the early medieval period might cause a route to be diverted to a suitable fording place or to the next nearest bridge, e.g. Chollerford NTB (see above p. 49) but if a ferry replaced the bridge there might be little modification to the route.

The building of a new bridge can attract travellers away from an old crossing place, e.g. at Abingdon BRK (see above p.49) and Boroughbridge YOW (see above p. 50).

c) The need to access new mineral resources

The main sources of minerals used by the Anglo-Saxons seem to have been the same as those used at earlier periods, and so the roads that they used were long established. Salt was obtained from Droitwich in the Iron Age and Roman times and so a distribution network had been instituted long before the early medieval period. Much of it would have coincided with the salt routes used by the Anglo-Saxons, most obviously the stretches along the Roman roads

The sources of iron (ore) in the Weald, of lead (ore) in Shropshire and in the Peak District were already served by Roman roads. It is unlikely that routes of any great length were created to exploit such resources as bog iron ore or building stone: the latter was too heavy and bulky to be moved far overland.

The one unexploited area that might have tempted the Anglo-Saxons to access its mineral resources was Dartmoor. The Vikings, raiding the English and continental coasts and seas, prompted the Anglo-Saxons to turn their activities in search of mineral wealth to the 
South-west, since continental resources were no longer readily available. ${ }^{7}$ Dartmoor had rich veins of tin and copper. An Anglo-Saxon tin-smelting site is known at Week Ford on the West Dart dated to $570-890{ }^{8}$ As Dartmoor's mineral resources do not seem to have been exploited by the Romans there are no Roman roads leading onto the moor, but there are examples of $\overline{o r} a$, Yarner Beacon, Hazard and even Yarner, which might be clues to the routes used in connection with copper and tin mining (see vol. 2 pp.284-5).

d) Changes in trading patterns both overseas and internal

There was early cross-channel trade with places on the near continent such as Dorestadt and Quentovic, from ports in the South-East. However, the Viking raids, especially in the period 830-880, disrupted trade from such ports as Sandwich, Canterbury, Reculver, Minster in Thanet, Sarre, Rochester and London as well as continental ports. ${ }^{9}$ Hamwic, established around $700 \mathrm{AD}$, was in decline after the mid-ninth century having been destroyed by the Danes by $842 .{ }^{10}$ One result was to increase the amount of trade based on western ports as the crosschannel routes between south-west England and western France were relatively safe. Exeter was well-placed for this trade and therefore grew. It was already well-connected to areas further east byRoman roads and so this may not have affected the road network. A second result was to increase the trading activities of centres further inland when trade was reviving in the tenth century, in such places as London, Lincoln, York, Winchester, Norwich, Thetford, Stafford and Chester, places already on routeways-in-use. ${ }^{11}$

The establishment of a Viking sphere of influence around the Irish Sea, much of it emanating from Dublin was probably responsible for the growth of the stceths and stoths on the Lancashire coast. There were links between the Vikings of Dublin and of the Irish Sea littoral with those of York, presumably using the trans-Pennine Roman road from Ribchester to York. This road has $\mathrm{OE}$ indicative place-names along it and was therefore likely to have been in use before this period. Between Ribchester and the coast the routes are as yet unknown, only Pressall's and Core's ofers giving a hint of one possibility. Routes in Lancashire may prove to be ones that came into being or to greater importance as a result of the Viking activity in the first half of the tenth century as there is little place-name evidence for their use.

Inland, the activities of the metal detectorists have identified a number of 'productive sites', places where finds of coins and other metallic objects are unusually plentiful. They are thought to be sites of fairs or markets, and as such needed to be readily accessible. The coin evidence is particularly strong for the periods $730-760$ and from the mid-ninth century which suggests that the roads serving those places were in use at those times and in particular it can indicate which routes were established by c. 700 (see below under coin finds).

e) The advent and spread of Christianity after 597

The advent and subsequent spread of the Roman form of Christianity gave additional reasons for travel. Priests and missionaries going from place to place preaching, and people were undertaking pilgrimages, some as far as Rome. St Wilfred and Benedict Biscop made such a journey from Northumbria in the seventh century as did others in later times. The shrines of St Cuthbert in Northumbria (at Lindisfarne, Chester le Street and Durham in turn), St Swithin in Winchester, St Alban (an early British martyr of perhaps the third century) in St Albans HRT, St Edmund (re-interred in the early tenth century)in Bury St Edmunds, ${ }^{12}$ and Glastonbury were favoured places of pilgrimage in the early medieval period. Roman roads led

\footnotetext{
${ }^{7}$ J.R. Maddicott, 'Trade, Industry and the Wealth of King Alfred', Past and Present, vol. 123 (1989), p. 17

${ }^{8}$ J.R. Maddicot, 'Debate: Trade, Industry and the Wealth of King Alfred: Reply', Past and Present, 135 (May, 1992), p. 181

9 Maddicott, Trade, pp. 8-9.

10 Cunliffe, Wessex, pp.320-2.

${ }^{11}$ Maddicott, Trade, p.11

12 Lapidge, Encyclopaedia, p. 161
} 
nearly to Glastonbury, and to all the others except Lindisfarne and Bury St Edmunds. The development of the shrine of St Edmund occurred quite late in the Anglo-Saxon period: the place-names indicate that it was not on the Icknield Way route into Norfolk. However a Gough route clearly makes a diversion to take in Bury St Edmunds indicating that here is a route that seems to have come to importance sometime between the early tenth century and 1360 .

The activities of the religious houses in draining the Fens and Somerset Levels resulted in a much longer, more usable network of waterways and landing places than existed earlier, but here again much of this activity was post-Conquest.

f) Changes in agricultural practice

An agricultural revolution took place in the closing centuries of the Anglo-Saxon era, affecting midland England especially. The adoption of an open field form of farming involved changes in the layout of the fields, and settlements became more nucleated. A similar process occurred when the open fields were enclosed, largely in the eighteenth and nineteenth centuries, when it was impracticable to modify the through routes in one parish very much as they still had to link up with those routes in adjoining parishes.

g) Changes due to urban growth

David Hill's Atlas of Anglo-Saxon England has maps of England, excluding Northumbria, showing places which had claims to be towns in the period $700-1066 .^{13}$ Many had access by water but they would also have needed access by land. An analysis of their situations shows that:

i) Large numbers were on Roman roads, e.g. London, Canterbury, Winchester, Salisbury, Leicester, Derby, York, so there was no problem with access and no need to create new roads.

ii) Large numbers were up to two miles from a Roman road and would therefore need short, local, but substantial, roads for access, e.g. Wilton, Wallingford, Lewes, Tamworth. These roads would not be long enough to have indicative place-names beside them.

iii) Some were on old trackways, e.g. Shaftesbury on the Great Ridgeway, Norwich on a westward leading road with indicative place-names beside it and by a navigable river; Christchurch Harbour at the end of a place-name indicative route up the Avon valley, Langport on Old Way and beside the river Parrett. Watchet, Barnstaple and Totnes were all beside old tracks. Axbridge is on an old route along the foot of the Mendips which has indicative placenames.

iv) Some were on minor roads. Buckingham and Bedford were beside the navigable river Ouse, and by the minor Roman roads M 166 and M 210 described by the Viatores. ${ }^{14}$

Buckingham is on a Gough route which leaves Watling Street at Fenny Stratford, goes through Buckingham and on west to Finmere and beyond. By turning north-east onto M 160a at Finmere, and crossing the Ouse at Water Stratford the traveller could rejoin Watling Street at Towcester (as shown on the end map). This seems to have been a diversion from Watling Street caused by the growth of Buckingham. Further north the Gough route again leaves Watling Street to divert through Daventry, Coventry and Coleshill to rejoin Watling Street at Lichfield. Coventry was a flourishing medieval town and as such would have attracted traffic, whereas the old Roman route from Towcester to High Cross passed few settlements of any size, was therefore not so attractive, and has no indicative place-names along it.

v) Other towns, developing for a variety of reasons, had no Roman road access nor roads with indicative place-names. Either there were good roads already in place but without placename evidence, or minor local tracks developed into important access roads well on into the early medieval period. Examples include the Alfredian burhs of Lydford DEV, Malmesbury

\footnotetext{
${ }^{13}$ David Hill, An Atlas of Anglo-Saxon England (Oxford, 1987), pp. 134-42.

${ }^{14}$ Viatores. Roman Roads, pp. 249-60 and 309-15
} 
SOM. Other towns include Shrewsbury, Nottingham, Ripon, Taunton and Stafford.

As urban centres usually grow up at route centres, or at least on a routeway, it is likely that most towns were developing because good roads already existed. In a few cases (section v above) towns seem to have grown up in spite of the lack of good road links and the towns were a later spur to development.

It is difficult to estimate the size of these urban centres, but they are unlikely to have contained more than a few thousand people, if that many. Some estimates have been made based on DB statistics. They include York 8,000, Norwich 6,600, Lincoln nearly 6,600, ${ }^{15}$ while Campbell suggests that Norwich had between 5,000 and 10,000 and that Winchester in 1158 had $5,500 .{ }^{16}$ London, as the primate city, would have had considerably more. ${ }^{17}$ These figures refer to the period after the spurt in urban population growth beginning about 900 to 950: populations before then were considerably less. The question as to how this urban population was to be supplied, especially with food and fuel, must have arisen at some stage whether the nearby countryside could have provided the necessary food and fuel or whether it had to be brought from afar.

It is known that salt and firewood were regularly traded over long distances (see chapter 5), so that it must have been feasible to move food to urban centres with growing populations. It is known that grain could be brought down the Thames to London as it was in post-Conquest times from Henley. ${ }^{18}$ The easiest way to supply an urban area with meat was to drive the animals from distant pastures to resting, fattening areas near the towns before slaughter. Short distance droving was common practice in early medieval times, e.g. in Kent swine were driven into the denns of the Weald, and in Warwickshire drove roads led from the Feldon to the Forest of Arden. ${ }^{19}$ Place-names suggest that animals were being moved by water. The four hyths, Bolney (bullock's hithe near Henley on Thames), Rotherhithe (on the Thames east of London) and Riverhead (on the Medway) both 'cattle hithe', and Lambeth (on the Thames opposite Westminster), imply that animals were being on- or off- loaded there. In the eighteenth and nineteenth centuries drovers followed traditional routes - wide grassy tracks like Banbury Lane and Welsh Road - thus avoiding the main roads. If such long-distance drove roads existed in early medieval times there may have been place-name evidence for such a network. ${ }^{20}$

h) Changes in transport technology

There was nothing as dramatic as the coming of the railways and motor transport with its effect on the communications network, but there was a slow improvement in horse trappings with the introduction of the horseshoes, stirrups and the horse collar (see p. 17). An improvement in the design and construction of carts is likely to have occurred too. These changes were not so dramatic that they would have altered the transport network significantly.

i) Political events: a few pointers

${ }^{15}$ Stenton, Anglo-Saxon, p. 538

16 James Campbell (ed.), The Anglo-Saxons (London, 1982), p. 174

17 'Primate' used as a geographical term refers to the largest town/city in a country or region which, according to the rank-size rule, is likely to be twice the size of the second largest town/city and three times the size of the third largest town/city and so forth

18 .R.H.C. Davis, 'The Ford, the River and the City', Oxoniensia, 38 (1973), p. 264: Blair, Waterways, pp. 122-3; Leslie Hepple and Alison Doggett, The Chilterns (Chichester, 1992), pp. 97-8.

${ }_{19}$ Everitt,Continuity, pp. 35-7; Della Hooke, The Landscape of Anglo-Saxon England (Leicester, 1998), p. 161

${ }^{20}$ Some names likely to be indicative of droving are: Galwaithegate LNC (c. 1190), 'the road to Galloway'; the 'Hollin' names beside drove roads, and a few of the netel nata names are some such, but there are no pre-Conquest spellings to take them back to early medieval times. The mersctüns might be important in this context, but much work remains to be done. See M A. Atkin, 'Hollin Names in North-west England', Nomina, 12 (1988-90, pp.77-88: Cole, Netel, pp. 49-58; Cole, Nata, pp. 51-3 
i) Early migration and settlement

The earliest Anglo-Saxon immigrants landed along the East Anglian coast and the southeast coasts and estuaries. Some stayed near the coast as they did at Mucking, others would have sailed up the east-flowing rivers, long distances along the Thames and other sizeable rivers, but shorter distances along the smaller rivers. When the head of navigation had been reached they would have to have proceeded overland. Cox, writing about the häm names of the Midlands and East Anglia says that as hăm was a term used in the early days of the settlement, its frequent appearance within 3 miles of a Roman road suggests that settlers were using the roads to penetrate inland and settling beside them as they progressed, once they had got beyond the head of navigation. Rivers and roads at this time were used as 'lines of penetration' by the incomers. ${ }^{21}$

The settlers formed small tribal groups at first, but as time passed these coalesced into small kingdoms. References to these events are very sparse, but contributors to Bassett have assembled the available evidence. ${ }^{22}$ The Tribal Hidage seems to reflect this process when it lists numerous small east midland peoples with hidations of 2,000 to 5,000, and four major Southumbrian kingdoms (Mercia, East Anglia, Kent and Wessex) with assessments between 15,000 and $100,000 .^{23}$

At this stage a network of local roads would have been used to access the various parts of each tribal group's territory/embryonic kingdom, but the need for a national network would have been limited. To maintain their position their leaders/kings needed to gift prestige objects or land to their followers. Some of the gifts would have originated overseas and would have been acquired by trading. This could be one of the factors behind the growth of the emporia or wics such as Hamwic, Ipswich, London and York. They were already well served by road and river routes and being accessible by sea from continental Europe, they were well-placed to develop international trade as well. This meant that road and river routes to these places took on added importance; all four are close to roads and rivers that placenames indicate were in use in early medieval times.

ii) Defensive sites

Cox's study of the distribution of burhs in Lindsey concluded that they were largely defensive sites dating from the time when Lindsey was a kingdom in the seventh century, and needing to defend itself from Mercia and Northumbria. ${ }^{24}$ The burhs commanded entry points along the coasts, the Roman roads and early trackways. That these roads needed defending against use by invaders implies that they were in use at this period. Some, but not all, have indicative names along them suggesting a variable survival rate as important routeways.

iii) Administrative centres

As Anglo-Saxon England developed and the smaller kingdoms merged to become larger ones so the need for administrative mechanisms and administrative centres grew. Eventually the shire towns fulfilled this function. An effective administrative centre needs good communication links with the area it has to administer. It is instructive to look at the shire towns to see how they are related to road and river routes. ${ }^{25}$ The shires arose at different times and had different origins. In essence, some, in Essex, Kent, Surrey and Sussex developed out of early kingdoms. Shires, and therefore, presumably, shire towns, in Wessex

${ }^{21}$ Barrie Cox, 'The Significance of the Distribution of English Place-Names in häm in the Midlands and East Anglia', JEPNS, 5 (1973), pp. 15-75, esp. pp72-3.

${ }^{22}$ Bassett, Steven (ed.), The Origins of the Anglo-Saxon Kingdoms (Leicester, 1989).

${ }^{23}$ David Dumville, Essex, Middle Anglia, and the expansion of Mercia in the South-East Midlands' in Bassett, Origins, 1989, p. 129: Lapidge, Encyclopaedia, pp. 455-6.

${ }^{24}$ Barrie Cox, 'The pattern of Old English 'burh' in early Lindsey', Anglo-Saxon England, 23 (1994), pp. 35-56.

${ }_{25}$ James Campbell, 'Power and Authority 600-1300' in D.M. Palliser (ed.), Cambridge Urban History of Britain 600-1540 9Cambridge, 2000). 
were in existence by the end of the eighth century or the start of the ninth. Two of the towns were centres acknowledged by groups of people: Dorchester by the Dornsiête people of Dorset and Somerton by the Sumorsäte (or Sumortünsēete) people of Somerset These two shires and shire towns seem to have been a recognition of a pre-existing situation. It is not clear how the other Wessex shires evolved

In the Midlands, shires were created around chosen shire towns sometime between the late ninth and the eleventh centuries. ${ }^{26}$ Those in the East Midlands were based around places where the Danish armies had established their headquarters, while those of the West Midlands - Mercia proper - seem to have been more deliberately planned. The shire town was a defensive site, supported by its shire, whilst also serving as an administrative centre North of the Humber, apart from York, the counties (or shires) are a post-Conquest creation. ${ }^{27}$

Fig. 10.3 summarises the accessibility of the shire towns in terms of river and road transport. All are by rivers or the coast: most are on navigable rivers, although in five cases only by small craft (canoe-sized today) and two others, now with many locks, would not have been easy to use. The only two shires not served by navigable water are Wilton and Somerton.

Twelve are served by major Roman roads, and a further three by minor ones, five more are within a couple of miles. Twenty named shire towns are shown on routeways on the Gough map: a Gough route probably went near, but not through, Wilton. Somerton was accessed only by Old Way (a herepeeth). Other towns served by neither by a nearby Roman nor a Gough road were Nottingham and Warwick.

Four of the Mercian shire towns have names in ceaster indicating that they arose on the sites of Roman towns or forts: two others, Lincoln and Cambridge, are on Roman sites. There are two ceaster-named shire towns in Wessex and one more, Canterbury, on a Roman site. Five of the Mercian towns have names in ford and one in brycg, hinting at important crossings since Oxford, Bedford and Hereford are on large rivers and Hertford and Stafford are on medium-sized ones. A site by a crossing is usually a route-centre and an important defensive site. In Wessex, only Guildford had a ford name.

In summary, these administrative centres whether chosen in the late-eighth-early ninth century in Wessex or in the early tenth century in Mercia were generally similar in terms of accessibility - they were often accessible by river and almost always by one or more important roads. It would appear that administrative centres only developed where communications were good and to that extent the road (and river) system determined where these towns grew up. The most obvious exception is Somerton, but it is likely that this shire town had a different origin to the others, having evolved as a centre for the Sumorsāte rather than being actively chosen for its role.

The names of all the shire owns appear in surviving records by the mid-tenth century and many appear in Bede. The fact that so many (all but five or six) are served by Gough routes is another hint that the Gough routes existed well before 1360 and perhaps back to the time when the shire towns were developing into administrative centres.

iv) The use of ON place-names as indicators of routes

The Danish and Norwegian settlers in northern and eastern England introduced numerous ON place-name elements, the most common of which are $b \bar{y}$ and thorp. There are two relating to routeways - gata and vath. Gata is frequently used of roads in towns or in the sense 'road leading to such and such a settlement', e.g. Haxey Gate NTT. Occasionally it is used in other contexts: Batham Gate DBY, Stangate Hill HNT, and Rudgate YOW, are all stretches of Roman road. Sawgate refers to a salt route, while Gate Helmsley means 'the

\footnotetext{
${ }^{26}$ Lapidge, Encyclopaedia, p. 421

${ }^{27}$ See for instance Stenton, Anglo-Saxon, pp. 336-8
} 
Helmsley on the (Roman) road'. Gargate LNC, 'the road to Galloway' is a drove road along the line of a Roman road. Fleet Hargate LIN, 'army road by the tidal inlet' perhaps refers to the routway linking the line of settlements along the silt fens between Spalding and King's Lynn, doubtless important locally but not part of the early medieval routeway network as indicated by place-names (gata is not an indicator of routeways in use). Huggate YOW, the only DB example of gata, like most villages in the Yorkshire Wolds is at the meeting of numerous minor roads, but not one highlighted by indicative place-names. Vath is described in chapter 4, pp. 44-5 where it was concluded that it was rarely used of fords on important routeways.

Overall these two ON place-name elements, gata and vath, contribute little to the major routeway nomenclature. The indicative place-names on routes running through Scandinavianoccupied England were almost entirely OE. The ON terms were used of smaller features on lesser routes and as such would be useful in identifying minor, local road networks. The dominance of OE terms on the major routes suggests that the naming was done before the Viking invaders introduced two potentially useful terms in their own language.

\section{Summary}

Two questions have been addressed in the foregoing paragraphs: firstly, if it is possible to narrow down the time span over which the indicative place-names were given, and secondly, if it is possible to suggest when the major routeway network was established. This does not mean when the roads were built (if Roman) or evolved from constant use (if other roads and tracks), but when a certain group of roads were recognised as being the most important and oft-used ones between distant destinations (settlements, ports, minerals etc.) and became the choice of ordinary travellers going on multi-day journeys. These would be roads that linked up with one another or with navigable waterways.

Margaret Gelling established that topographical terms, especially OE ones, referred to the same landforms or water features throughout England although she did not opine whether this was so from the earliest days of settlement or not. Cox's list of pre-731 names has many examples of the use of $\bar{e} g$ and a few of $d \bar{u} n$ in place-names from widely separated areas. These appear to be consistently used in their own categories and with the way they are used in later times. Therefore, it seems safe to assume that at least the topographical place-name elements had a uniform meaning throughout the English speaking areas: it is possible, then, that a widespread system of naming features important to travellers could have arisen before 731.

The lack of the use of $\mathrm{ON}$ terms helpful to travellers on major routes might suggest that the naming system was substantially in place by about 850 , before the Viking raids and settlements took place bringing ON terms into the vocabulary and available for use. This does not mean that occasionally indicative names were not given later. It raises the question as to whether OE indicative place-names would have been coined in the Danelaw during the period when the Vikings held sway up until the re-conquest: circa 920 as far north as the Humber and 973 to include Northumbria. There is no reason why Anglo-Saxons living under Danish rule should not have given settlements OE names, but unlikely that any Danes in authority would have done so. Much, therefore, depends on who was coining the settlement names, especially the indicative ones.

On the one hand, if the road network, particularly in the (future) Danelaw, and its indicative place-names was a feature of peacetime development, at a time when neighbouring kingdoms were on good terms with one another, then the periods roughly from 700 to 850 and from the mid-tenth century were the most likely. The mid-tenth century is too late for the system to have started to emerge; many of the indicative place-names are recorded before that. On the other hand, in Anglo-Saxon England, at the time when Alfred the Great and 
Edward the Elder were strengthening the defences of Wessex and Mercia with their defended burhs they may also have wanted to make road travel for the movement of the fird more efficient, in which case the drag-tüns and -cots could have been so named and their functions recognised or created. It is possible, though less likely, that the mör-tüns and meretüns were also recognised and named, or re-named, at this time as having a particular function - the functional tüns certainly appear to be later coinings. However, many categories of indicative names, particularly the topographical ones describing water sources, crossings and useful landmarks, had probably originated long before as was suggested in the early part of this chapter: the features were in the landscape anyway and required no human intervention to create them unlike the functional tiuns.

When it comes to the development of the road system, the general impression is of stability. The Roman roads and numerous tracks, large and small, were already in the landscape when the Anglo-Saxons arrived. Their unconscious selection by frequent use of the routes which would become a network of major routes seems to have happened early in the Anglo-Saxon centuries and to have changed only very slowly in the succeeding ones. Many Gough routes seem to have been established well before the Conquest and must have existed at least three centuries before the surviving Gough map was drawn. Any changes were fairly local and did not all take place at the same time.

Overall, the road system is likely to have been established early on, and so were the topographical names, but the functional $t \bar{u} n$ indicative names arose somewhat later. As the centuries passed small changes were made to the road system and a greater variety of indicative names came into use.

The set-up outlined in this thesis is but the framework within which an intricate trackway network existed in early medieval England. Studies of the intervening areas, especially through charters and field work, may identify local networks and how they might link into the national network.

\section{EVIDENCE FROM COIN FINDS}

Has any evidence been left by travellers of their use of the roads? Did the merchants and the buyers drop their money by the wayside as they travelled, losing a coin or two at a campsite or at the site of a fair? Does the distribution of coin finds mirror the route-way network and if so, do the coin finds occur along routeways which the place-name evidence suggests were in use? Do the two types of evidence point to the same conclusions?

Coins could be used for several purposes, for instance, as part of a piece of jewellery, as grave goods, as well as for facilitating trade. It is the earlier, higher value coins (thrymsas) that are most often found in jewellery or graves; the great majority of the low value coins produced from the end of the seventh century onwards were used in trade. Trade implies the movement of goods from the point of production to the point of consumption. It involves at least one transaction, either by barter or monetary exchange; often there will be several transactions especially when the distance involved is long or the means of carriage varies. Thus, coins are particularly associated with routes and trading places. However, people in settlements which were not on major routes would also need coins, for their transactions with passing pedlars or at a nearby market. There are many opportunities for coins to be lost, dropped in the market place; slipping unseen through a hole in a pocket or purse on the roadside; slipping onto the floor of a home, being swept up, put on the midden and eventually reaching the fields. Coins could be lost and found in a great variety of places, but it seems likely that a goodly proportion would be lost on trade routes or at market places.

Of course, not all the lost coins that have been found have been recorded. Some of the finds were made long before such things were recorded (unless they were valuable hoards). In recent decades, with the advent of metal detectors, great numbers of single finds have been 
made and recorded, but it does not necessarily reflect the distribution of coin losses; it reflects the activities of detectorists and their distribution, of landowners who allow the detectorists access, and the type of land where detecting is most rewarding - arable being much preferable to pasture. This latter factor results in more finds in eastern England than in western areas. Exactly how far this reflects detectorists' activities and how far it reflects the coin losses of the early medieval period is hard to tell. Excavations of archaeological sites also produce coins, and, as these are often habitation sites or cemeteries, this can skew the distribution; the distribution of digs will affect the distribution of coin finds.

The Fitzwilliam Corpus of Early Medieval Coin Finds is an excellent source of information giving, where known, the name of the mint, the date range of minting and the grid reference of the find spot. ${ }^{28}$ Since the coins can be roughly dated, and are widely found, it should be possible to correlate coin finds with routes-in-use at different periods in AngloSaxon England. Many reservations have already been noted (such as unevenness of finds; losses in situations other than on routes), but there is another problem in that the corpus does not record the exact find spot of the coins, but gives the four-figure grid reference of the nearest large settlement or parish in which the coin was found. It is therefore not possible to tell if the coin was found on the route-way or not. The best that can be done is to see if the modern parish boundary touches on, or includes, a stretch of Roman road or one of the old routes discussed earlier (e.g. the Icknield Way or a Gough or Ogilby route). If it does there is a chance that the coin was found by the roadside, but also a good chance that it was not! If the parish boundary does not touch or include a routeway then the coin was probably lost in a domestic situation rather than a trading one. Since the exact find spot is unknown it is not possible to apply the chi-squared test as could be done with place-names.

It is not normally possible to tell how long after minting the coin was lost, although it was probably not many years. In the late tenth and eleventh centuries coins were recalled and reminted every few (four to six) years, so coins of this period lost on routeways indicate that the route was in use between closely defined dates. With earlier coins it is not possible to be so exact, although as sceattas are rarely much worn they probably did not circulate for very long.

Some places appear repeatedly in the corpus as 'find spots'. They are not the sites of hoards, but places where one or two coins were lost at a time over many years. They are known as 'productive' sites, and are likely to be the sites of markets or fairs. This information could be useful as indicating meeting places and hence route-centres, and, if the coins are of a restricted date range, of the period when the market or fair was flourishing.

Two sets of data were collected from the Fitzwilliam Corpus. The first included coins minted between 710 and 750 . Large numbers of coins were minted in England during this period as reflected in the numerous finds. For Northumbria slightly different dates had to be used: 737 to 758 - the reign of King Eadbert. The second set of data covered the period 978 to 1050 ; in this period coins were withdrawn from circulation and re-minted every few years (usually six), so they can be quite precisely dated, and they are likely to have been lost during the years when they were in circulation. The chosen period ends well before the upheavals of the Norman Conquest. The two sets of data were mapped on routeway maps (figs 10.4 and 10.5). In each case the solid circles represent at least one coin find, sometimes many, in a parish through which, or along whose boundaries, runs either: a) a Roman road, b) one of the 'ancient tracks' shown on the O.S. Map of Roman Britain, c) part of a Gough or Ogilby route or a ridgeway, which the place-name evidence indicates was in use (these are not shown on figs 10.4 or 10.5 for lack of space), d) a navigable waterway. The coin(s) could, therefore, have been lost by a traveller on a route-way (whether or not in the case of a) or b) the route is

${ }^{28}$ www. fitzmuseum.cam .ac.uk/coins/emc 
thought on place-name evidence to have been in use at the time). The open circles represent finds in other parishes; triangles represent Northumbrian coins. The two maps could then be compared with one another and each can be compared with the routeways-in-use map

To take first the two coin distributions, a comparison of the 710-750 map with the 978 1050 map shows a broadly similar distribution: the great majority of find spots are south-east of the Fosse Way (few coins circulated in the north-western areas); there are particular concentrations in north-east Kent, the Sussex coast, the Oxford/Dorchester area, to the south of Cambridge, the eastern Fen-margin, north-west Norfolk, south-east Suffolk and Lincolnshire. However, several changes occur in the two and a half centuries between the maps, notably:

i) Changes from many finds of 710-750 coins to few, if any, finds of 978-1050 coins occur in or along: the Thames estuary, north-west Norfolk except along the Icknield and Peddars Ways, south-east Suffolk except around Ipswich, and along the Icknield Way/Great Ridgeway south-west of Dunstable. The most dramatic change is from the many 710-750 finds along the routes over the Yorkshire Wolds from York to Bridlington to none at all. ii) Changes from few finds of 710-750 coins to many finds of 978-1050 coins are few. The appearance of non-route-related finds between Northampton and Irchester is the most notable. In general there are more non-route-related finds.

A study of the distribution of coin finds on its own would not yield a map of routes in use, but if considered in conjunction with Roman roads, ancient tracks, and navigable waterways can suggest a number of routes in use, both road and river. However, because coins were rarely used north and west of the Fosse Way/Great North road, the information that can be gleaned is largely restricted to areas in the south and east of England; it is commented on further below. The distribution of the coin finds by route-ways could be used to support, or contra-indicate, the routes-in-use deduced from the place-name evidence. Where the two are coincident there is strong evidence that a route was in use, where only one type of evidence is present the route was less certainly in use. Where neither type of evidence occurs, then the route is unlikely to have been an important part of the country-wide network, although the road or track may have been in use very locally.

The next question to consider, therefore, is whether the routeways-in-use network suggested by the coin finds reflects the routeways-in-use network suggested by the placename evidence. Although the place-name, or rather the settlement with the relevant placename, does not have to be astride the route itself, particularly if it is a landmark term such as cumb-tūn or öra, it is rather different in the case of coins; the find spot needs to be on or very close to the route-way to have been dropped by a traveller en route, or at an overnight halt. Unfortunately this information is not available on the Corpus. All we know is whether or not a Roman road or other significant route passes through, or alongside, the estate or parish in which the coin was found. The coin need not necessarily be associated with the road or the overnight halt; thus some of the coin finds noted as being by route-ways may have little to do with losses by travellers (this is especially true in the case of large or elongated parishes). The evidence is not reliable, and this must be borne in mind when comparing distributions.

Taking the 710-750 distribution first: in north-east Kent the two distributions are generally coincident, although the coins suggest the use of the Richborough to Dover (M 100), and Great Chart to Lympne (M 131) roads, which the place-names do not. In Sussex the distributions are broadly similar, but there is no coin evidence of the use of the three transWealden Roman roads (M 15, M 150, M 14), although the place-names indicate otherwise. Near Winchester both place-names and coins indicate that the old route from Winchester via West Meon to Butser and the South Downs was in use. Further west around Badbury, coin evidence is sparser, but generally in agreement with the place-name evidence along Roman roads, Gough and Ogilby routes. 
There is place-name evidence for the use of the London to Silchester route, $M 4 a$, but the only coin find on this stretch was at Staines, and it might equally well have been lost by a Thames boatman as a road traveller. In the Oxford area there are large numbers of indicative place-names and of coin finds. Both suggest good use of the Icknield Way between Dunstable and Goring; of the Silchester to Alchester road (M 160); of the Dorchester to Fleet Marston road (M 173a), and of the Ogilby route (Banbury - Chichester) from its crossing with Akeman Street to Newbury. Numerous finds beside the Thames from Eynsham to Reading agree with the $h \bar{y} t h$ and $\bar{e} a-t \bar{u} n$ evidence that this was a well-used waterway.

There have been large numbers of coin finds in East Anglia; the Roman road, M 3, from Colchester to Norwich is well indicated by both coins and place-names, but only coins suggest that M 34b, Baylham to Yoxford road, was used. Both indicate plenty of activity in the coastlands east of Ipswich, a lot of it related to water-borne traffic accessing the kingdom of East Anglia. North-west Norfolk is well supplied with coin finds; the two main northsouth routes - Peddars Way from Holme-next-the-Sea to Stanton Chare (M 33b), and the Icknield Way from Holme to Thetford - have a good scatter of coin finds supporting the place-name evidence, but the M 58, from the eastern edge of the Fens to Bawdeswell, the turning for Norwich, is much better supplied with coin than place-name evidence.

The eastern Fen margin has many coin finds all associated with navigable waterways, and mostly where water and land routes meet, very much like the situation of the hithes. In Norfolk there are many coin finds not associated with recognised Roman roads; it was a prosperous area and one easily crossed by travellers since it is relatively flat and welldrained, and so this is not too surprising.

The area south of Cambridge is well supplied with coin finds and indicative place-names, but the place-name distribution indicates that the Braughing - Sandy - Godmanchester road (M 22) was in use, but the coins suggest the alternative Braughing - Wimpole Lodge Godmanchester ( $M$ 2b) road was used.

In Lincolnshire both coin finds and place-names indicate that High Street was in use, as was the road from Lincoln to the Trent (M 28a), and the Trent downstream of Torksey. North of the Humber, from North Ferriby to York, there have been finds of Northumbrian coins along $M 2 \mathrm{e}$, a route with only doubtful place-name evidence (see mere-tün). However, the finds in the Yorkshire Wolds follow both routes, M 810 and M 811 (York to Bridlington), reinforcing the rather sparse place-name evidence. North-west of York there have been few coin finds, and most of these have been at religious sites, Jarrow, Whitby and Whithorn for instance, and represent pilgrim traffic rather than commercial traffic.

The situation on the longest national routes (as opposed to the regional ones above), is as follows:

Watling Street: Dover - London - High Cross - Pennocrucium (M 1), the coin and placename evidence agrees well, except for coin finds at St Albans, which was a destination for pilgrims, otherwise the same absence of evidence of use occurs between London and Dunstable, and from just north of Towcester to High Cross.

The Fosse Way: there are few coin finds this far west, and none on the Fosse Way between Exeter and High Cross, with the exception of Northleach, which in any case is on an east west route in use. It is the stretch from Six Hills to Lincoln, which has coin but not placename evidence.

The Icknield Way is well supplied with both coin and place-name evidence. Its continuation, the Great Ridgeway, has place-name evidence, but the coin evidence becomes very sparse to the west.

The Harroway between Guildford and Ilchester has neither place-name nor coin evidence.

Overall, the evidence from coins minted between 710 and 750 is supportive of the placename evidence, but it can only be used in southern and eastern England, and the data are less 
reliable. The two stretches of road where there is coin evidence but the place-name evidence is insubstantial are from North Ferriby to York, and along the Fosse Way from Six Hills to Lincoln.

There are fewer find spots of coins minted between 978 and 1050, particularly around the coasts of Suffolk, Essex, the Thames estuary and south-east England, and very few around the eastern edge of the Fens. On the other hand, there are more non-road-related finds particularly between Northampton and Irchester. Looking first at the longest routes: Watling Street now has no coin finds along it, nor has the Fosse Way except at Leicester (a road junction). The Icknield-Great Ridgeway has fewer than before, and as they are at road junctions it does not necessarily indicate use of the Icknield-Great Ridgeway. The Harroway west of Guildford has but one coin find beside it. There is a much higher proportion of find spots in parishes without a Roman road or 'old route' (as identified by place-names) going through/by it, than in the 710-750 period. This could signify other routes coming into use, more casual losses around dwellings, or more transactions in local settlements. Some routes were still picked out by the coin finds, especially the Peddars Way (M 33b) from Stanton Chare to Holme-next-the-Sea, M 53 to Bath, and a cross-country route from Ipswich to Leicester (M 24 and M 57). The lack of coin finds along the Fen edge at a time when the latter were being brought into use by the monasteries is notable.

Metal detecting has revealed a number of places called 'productive' sites; they may be permanent settlements or sites of markets and fairs (as mentioned above). If the latter is so, one would expect them to be readily accessible since trading usually takes place at a meeting of routes such as cross roads, fording or bridging points, or landing places. For reasons of security the locations of some sites are given in only the vaguest way such as 'South Lincolnshire' but others are more precisely given.

The corpus can provide a histogram of any location showing the number of coins found at that place, divided into 10-year periods, apparently according to the date of minting; how a coin whose minting date is given as a range of 50 or so years is assigned to a particular 10year period is unexplained. ${ }^{29}$ Nevertheless the minting-dates of coins found in 'productive' sites falls into two main periods, 700-760 and 840-860, according to the histograms; the exceptions are at Bury St Edmunds, where the coin finds are mostly after 930 and presumably connected with the shrine of St Edmund, as was the diversion from the Icknield Way by the Gough route heading for Norwich. The other exception is Newbald (Sancton) where most of the finds, which date between 740 and 760 - some 40 years later than elsewhere - are Northumbrian stycas, as there was a hiatus between the end of the sceattas in c. 740 and the start of the broad pennies in the 760s. At Flixborough, Torksey, South Newbald, Malton and Cottam a second peak occurs at 840-860. These places were trading in what became the Danelaw at a time of increasing Viking raids. Flixborough is accessible from the Trent through its stothr; Torksey is well-placed at the junction of the Trent and the Foss Dyke; South Newbald is at the junction of M 2e and M 29. The former is the road from North Ferriby to York which is highlighted by several coin finds but very poorly by placenames. Roads to Malton are not indicated by place-names. Cottam is on M 810 between York and Bridlington, but the place-names indicate the use of the sub-parallel and more northerly route $\mathrm{M} 811$.

Of the more southerly sites, Canterbury and Reculver are served by both road and coastal routes. Inland, Royston is at the crossing of the Icknield Way, which place-names show as being in use, and $\mathrm{M} 2 \mathrm{~b}$ which is without indicative names, although it is a Gough route, and has coin find spots beside it. Bedford is accessible along both the Ouse and a minor Roman

\footnotetext{
${ }^{29}$ In some cases there are more coin finds listed than appear in the histogram. It is not possible to reproduce the histogram straightforwardly using the minting-date ranges given in the individual coin details.
} 
road; place-names indicate that the river was in use but not the road. Barham and Coddenham SFK are close to a junction of five roads at Baylham (Combretovium), two, possibly three, of which were in use according to the place-name evidence; they are also near the wic at Ipswich. In north-west Norfolk, Bawsey is quite near the Icknield Way on a coastal e'g site. Bidford WAR, is the most westerly of the 'productive' sites, where M 18a crosses the Avon; there are numerous roads - Roman, saltways, and Ogilby - in the area and a navigable river, so it was easily accessible.

\section{EVIDENCE FROM POTTERY FINDS}

Another potential way of checking the routes in use in the early medieval period is to look at pottery distributions. This, like coin distributions, has its limitations. The first lies in the pottery itself; pottery varies greatly in quality. Much of it is coarse ware, made very locally and without distinguishing characteristics, and so it is impossible to tell how far it has travelled. If, however, the pottery is good quality it may be in demand in places far distant from its point of production. In addition, it needs to be distinctive so it can be readily distinguished from other types of pottery. If there is only one centre of production, all finds must emanate from this centre, and that is helpful in tracing routes. If the time when the pottery was being made is known then the time period when it was being distributed is also known, and thus the routes can be said to be in use at the same time. Ipswich ware, produced between c. 650 and 850 , fulfils these criteria well.

The second limitation lies in the distribution of find-spots. Many of these are likely to be identified by field-walking, this in turn depends on whether or not the land is ploughed, and this in turn would predispose the finds to be made in the eastern half of England. Other findspots are on excavation sites, and these too are not a random selection; for instance, they may be sites of rescue digs, areas of intensive study (such as Whittlewood), or smaller sites of particular interest or ready access (such as Wharram Percy). Therefore it is not possible to tell to what extent the pottery is likely to be in use in small settlements in the middle of nowhere, as compared with its use in large settlements or beside the routes along which it was distributed. Are, for instance, the numerous finds of pottery in Norfolk (as compared with Suffolk) due to intensive field-walking in that county, or does it reflect the genuine distribution of pottery sherds in the East Anglian counties? Since the advent of the metal detector many people go searching for coins but field-walking for pottery sherds does not have quite the same appeal!

The third limitation lies in the reporting of finds. They often lie buried in excavation reports (if published); these tend to concentrate on the appearance of the pots and structure of the kilns rather than on the distribution of the find-spots, and so gathering the information can be very time-consuming, since comprehensive lists of find-spots are few and far between. This means that maps 10.6 and 10.7, showing the distribution of finds of Ipswich ware and Stamford ware (to a lesser extent), are incomplete, although they give some impression of the distributions. There is a useful account of the pottery industry of Stamford, which includes a distribution map, ${ }^{30}$ and another on the Lincoln and Stamford ware finds in Lincolnshire. ${ }^{31}$ The distribution of Ipswich ware, being produced between c. $720-850$, is more elusive; the maps in Anderton are too small to show up any relationship with particular routes in most instances. Moreover, the two maps which show the find-spots do not tally with

\footnotetext{
${ }^{30}$ Kathy Kilmurry, The Pottery Industry of Stamford, Lincs., c,A.D. 850-1250 (BAR British Series 84, Oxford, 1980), pp. 160-1.

${ }^{31}$ Leigh Andrea Symonds, Landscape and Social Practice: the production and consumption of pottery in $10^{\text {th }}$ century Lincolnshire (BAR British Series 345, Oxford, 2003), pp. 137, 141-6.
} 
one another. ${ }^{32}$ There is a useful list of find-spots in EAA report 84 , but this only covers Suffolk. ${ }^{33}$ Fig. 10.6 was compiled from these sources (together with a few other passing references to finds); therefore it can only give a general impression of the distribution of Ipswich ware finds. It shows a marked concentration in East Anglia, particularly around Ipswich and in Norfolk. Within this pattern can be discerned a trail of find-spots north from Ipswich around the Suffolk and Norfolk coasts to the Wash, culminating in clusters around Wisbech and Bicker Haven. A trail leads south along the coast from Ipswich, past the Thames Estuary and round the Kentish coast as far as Hythe. It is clear that the pottery was being moved up-river from the Wash, especially along the Nene, where it reached upstream as far as Weedon on Watling Street. The Great Ouse was also being utilised, there being finds in the Milton Keynes area, again near Watling Street (although this is not to say that pottery was being moved along this road). The concentration along the eastern margin of the Fens suggests that these rivers were being used. There are finds near the Little Ouse at Brandon (Otringhithe is nearby); there are finds too, near the Lark at Freckenham, Mildenhall and Eriswell (Lakenheath, a hithe, is nearby), and others at Exning near Reach Lode. In Suffolk there are large numbers of finds, especially close to the river Deben, and a few by the Alde and Butley rivers, just up-coast from the Orwell on which Ipswich stands. The Deben and Alde are notable in place-name terms because the only two ora names north of the Thames Estuary are beside them.

There are numerous places within a few miles of Ipswich, which are not accessible by water, Grundisburgh and Culpho for instance, so pottery must have been moved by road for short distances. Evidence suggesting that pottery was being moved long distances by road is sparse; there are few sites close to Roman roads or other old routes that are not also by navigable water, but Mendlesham on M 3 is one, North Elmham near M 38 another; both roads are thought to have been in use from the place-name evidence. Beyond East Anglia there are occasional finds of Ipswich ware, several on the Thames (near Staines, Oxford and Eynsham), several on the navigable part of the Trent (Flixborough, for instance), York on the Ouse, and Beverley on the Hull. Other finds seem to be well away from navigable water Wharram Percy YOE, and some of those in north Lincolnshire on Blinkhorn's map, appear to be by the Roman road from Lincoln to Winteringham (M 2d).

It seems clear that Ipswich ware was being moved by boat where possible, and that the rivers most used were those which place-names also suggest were in use: the Nene, Great Ouse, Little Ouse, Trent, Thames and Deben. A bulky and breakable commodity like pottery is much better moved by water (the potteries of Stoke-on-Trent flourished once the canals had been constructed); even so, it was moved for short distances overland mainly to places near Ipswich and the Deben valley. It is not possible to tell just how the pottery reached the many settlements in Norfolk from the maps in Anderton: whether it came up-river from the Fen edge or along the Waveney, Yare, Bure or Wensum and then by road, or whether it came all the way by road from Ipswich. The former seems more likely. Ipswich ware was being produced from about $720-850$; its distribution suggests that water transport in this period was very important.

In the ninth and tenth centuries Late Saxon Oxford Ware (OXB) was being produced, probably in the vicinity of Oxford; its sherds are found by the Thames (Oxford, Abingdon, Dorchester, Wallingford, Cookham, Old Windsor and London) prompting Maureen Mellor to

\footnotetext{
${ }^{32}$ MikeAnderton (ed.), Anglo-Saxon Trading Centres: Beyond the Emporia (Glasgow, 1999), pp. 7, 40. Paul Blinkhorn's projected work The Ipswich Ware Project: Ceramics, Trade and Society in Middle Saxon England from which the figure on p. 7 has been derived has yet to be published (format and date unknown).

${ }^{33}$ Stanley West, A Corpus of Anglo-Saxon Material from Suffolk (East Anglian Archaeology 84, Ipswich, 1998), pp 317-9.
} 
comment that ' ... distribution of this ceramic tradition may reflect river transport'. ${ }^{34}$ Other finds from Gloucester, Worcester, Droitwich and north-west Oxfordshire (north of the Thames and west of the Cherwell) suggest a connection with salt routes, but without knowing the find spots in rural Oxfordshire more exactly this idea is not possible to pursue further.

Stamford ware from Lincolnshire was being produced between about 850 and 1250 , somewhat later than Ipswich ware. Kilmurry ${ }^{35}$ gives a list and map of find-spots from which the routes used in its distribution can be inferred (see fig. 10.7). These finds are concentrated in Lincolnshire, Rutland, Leicestershire, Huntingdonshire and Bedfordshire. Many pots destined for use in Lincolnshire would have been taken down the Welland, along the northwestern edge of the Wash (there is a string of finds in the erstwhile coastal settlements between Spalding and Wainfleet), and more on the east Lincolnshire coast as far north as the mouth of the Trent; however, most of the other finds in Lincolnshire would have had to have been moved overland since they are not near navigable rivers. One such road was Barton Street/Louth Street. Off-loading from boats at Friskney, pots could have been carried along this road which lies close to the junction of Wold and coastal marshland, as far as Welton (GR TF 2787). Another route used was the scarp-crest or scarp-foot road along the western edge of the Lincoln Wolds; there is no place-name evidence of either road being used.

A short road journey from Stamford to Castor (M 2), would give access to the river Nene, along which is a scatter of finds up-stream as far as Northampton. The Great Ouse was also utilised, mostly up-stream of Godmanchester as far as Bedford; the pots could have reached the Great Ouse either by the Roman road, M 2, or by Fenland waterways using Car Dyke and Cnut's Dyke - there is nothing to show which route was favoured. There are finds beside the Trent, mostly between Newark and Nottingham, and the non-riverside finds hint at the use of M 580, Sewstern Lane, between Stamford and Newark. Other finds are well scattered over England, from Bristol to Winchester, London, Durham and Runcorn - as Kilmurry says, 'its wide distribution reflects growth of the market economy in the late Saxon period and the well established medieval trade network', ${ }^{36}$ a network where water transport, certainly for commodities like pottery, was very important and utilised the water routes highlighted by place-names and the distribution of Ipswich and Stamford wares. In areas distant from navigable water overland routes were used but the cost of transport, increasing with distance from Stamford, would eventually make the cost of the pots unaffordable for the ordinary person. Potsherds found in distant places such as Bristol, Chester or Durham may have originated, not from trade goods, but from personal possessions carried from place to place on a number of journeys and eventually broken and discarded.

Symonds' study of Lincolnshire pottery includes distribution maps of Lincoln and Stamford ware pottery finds in Lincolnshire, but not beyond. The Stamford ware find spots as mapped in Kilmurry are very similar, but not identical to those of Symonds. Kilmurry shows more on the coast north of Skegness than Symonds does.

Symonds does not list the find-spots of the pottery, but by superimposing the Stamford ware find-spots map on the Lincoln ware map it becomes evident that both types of pottery are found in the same places in many instances, especially south of the Lincoln to Grainthorpe road. Much the same distribution network was evidently in use, although the goods originated in different places (Lincoln and Stamford). Stamford ware find-spots are

\footnotetext{
${ }^{34}$ Maureen Mellor, 'A Synthesis of Middle and Late Saxon, Medieval and Early Post-medieval Pottery in the Oxford Region', Oxoniensia, 59 (1994), p. 40

${ }^{35}$ Kathy Kilmurry, The Pottery Industry of Stamford, Lincs. c. A.D. 850-1250 (BAR, British Series 84 Oxford, 1980), pp. 160-1.

${ }^{36}$ Kathy Kilmurry, The Pottery Industry of Stamford, Lincs. c. A.D. 850 - 1250 ( BAR, British Series 84, Oxford, 1980), p. 1 .
} 
more frequent south of Lincoln than are Lincoln ware find-spots, but Lincoln ware has more find-spots north and east of Lincoln than does Stamford ware. Lincoln ware is found in many more sites and further from the Roman roads than Stamford ware. It is evident that Lincoln ware was widely used in Lincolnshire from c. 850 on, but Symonds data do not tell us in what other counties it was found, so it is not possible to see what more distant routes may have been used.

The distribution of find-spots of Ipswich, Lincoln and Stamford wares all point to the importance of water transport where practicable. Where there were no navigable rivers overland routes were used - often Roman roads, but also some other old routes. More roads were pressed into service by the need to transport pottery to a multitude of small, rural settlements than are shown as being in use by coin finds or place-name evidence. The three sorts of evidence for routes-in-use derive from the travel requirements of the three different groups of people: those supplying pots to the rural settlements which could be distant from any main road but within the hinterland of a local pottery, the coin users such as the merchants and traders buying and selling goods at towns, fairs and markets, which would need to be on the more important roads for access, and a variety of people, such as pilgrims, preachers, messengers, government officials, royalty, pedlars, craftsmen and armed bands as well as merchants, some needing to travel long distances on well-recognised routes. The latter were the most likely to be using the place-name evidence. These differing needs help to explain why the evidence of routes-in-use provided by place-names does not always agree with that provided by the pottery or the coins.

The evidence used above, and available generally from both coins and pottery, is concentrated in eastern England and somewhat biased towards where detectorists, archaeologists and field-walkers have been active, and according to what find spots have been published and are easily accessible. Place-name evidence on the other hand is much more evenly spread over England than these, in spite of the documentary evidence from the northern and north-western counties being poorer than that from the south, and the possibility that some evidence from the Danelaw may have been lost through name changes as the Scandinavian settlements spread. Pottery and coins can be more closely dated in the early medieval period than can place-names; they offer the possibility of investigating when certain route-ways were in use or had fallen out of use, but this would need a detailed study of coin types that has not been undertaken here, and it would need a lot of painstaking work to assemble pottery types and find-spots like the Early Medieval Pottery Project has done for Lincolnshire; the time is not yet.

\section{CONTINUITY IN THE USE OF ROMAN ROADS}

Many modern routes follow very closely the lines of Roman roads. They range from major routeways such as A5/Watling Street to footpaths and bridle ways such as M 160b over Otmoor OXF. Sometimes the modern route is superimposed on the Roman road; sometimes the two are so closely adjacent that it is clear that the modern road is following the Roman route. In places the close correspondence has been destroyed for short stretches by the building of, say, an airfield, a by-pass or housing, and so the survival in use of that Roman road is patchy.

Do the Roman roads, which place-names and coins suggest were in use in early medieval times, correlate with the Roman roads which are in use today or, in other words, is there an apparent continuity of use of routes from Roman times to the present day (present day is taken to mean the latter part of the twentieth century)? Have some roads fallen out of use since the early medieval period, or has the opposite happened and have some Roman roads come into use (or perhaps back into prominence) again after the early medieval period? Fig. 10.8 lists some longer stretches of road in these various categories (note that coin finds are 
unlikely anywhere in the more westerly areas and so their absence from roadsides is not especially significant)

Roman roads (examples 1-10 in the figure 10.8) in use now and which have indicative place-names along them usually have coin finds along them too, unless they are in western areas. The same is true for Roman roads which are in use along substantial stretches but not continuously (11-16). Another group of roads surviving in use has slender coin evidence, but no place-name evidence; their surprising lack of the latter has been noted in chapter 9 (1722 ). A small, third group consists of Roman roads no longer use but with place-name evidence and some coin finds (23-25). The fourth group consists of disused Roman roads, having no indicative place-names nor coin finds beside them; they tend to be in the less desirable areas for settlement such as the Weald or Lancashire mosses (26-31). Lastly, three long distance routes are listed (32-42); the Fosse Way from Seaton to High Cross continues in use, is well-marked by place-names, but there are no coin finds; however, the stretch from High Cross to Lincoln, although it has no place-names, does have coin finds. Much of the north-western end of Watling Street, beyond High Cross, is in the area where coin finds are rare - their absence from Watling Street here is not surprising; evidence for its use from London to High Cross from both place-names and coins is poor as noted in chapter 9 . A route using Roman roads from London to Exeter, via Silchester, Salisbury, Badbury and Dorchester, which looks attractive on a map, in fact survives only patchily in practice; although its place-name evidence is quite good, there are few coin finds.

It would be unrealistic to examine all the short stretches of Roman roads between every junction this way; the place-names do not occur at sufficiently short intervals and the coin finds are too sparse to highlight such roads at all reliably. The longer stretches listed above do, however, suggest that a) most of the Roman roads which were in use in early medieval times have continued in use until today; $b$ ) that those with neither place-name nor coin evidence are not in use today; c) that those in use today, but with no place-name evidence of use, do have coin evidence, however slender; d) Watling Street stands out as being surprisingly unimportant.

On the whole this evidence suggests that routes are long-lived features of the landscape, persisting in use for hundreds, and sometimes thousands, of years so long as they connect places that people want to go to. 


\section{CONCLUSION}

There is a gap of about 950 years between the end of the Roman period and the drawing of the surviving version of the Gough map. Many of the routes of the Roman period are known because of the physical remains of the roads; some routes of the fourteenth century are known from the Gough map. For the period in between the evidence is less direct, and must be gleaned from other sources. For the post-Conquest period there are the itineraries of the kings, especially that of Edward I, which list the monarch's halts each night; from these it is sometimes clear what route he is likely to have used, although, as he did not necessarily stay at a place on a major route, these data need to be used with care because the beginning and end of his journey might have been on quite a minor road. There are fourteenth-century accounts of the repairs and maintenance needed on roads, ditches and causeways associated with tracks of varying degrees of importance enumerated by Flower. ${ }^{1}$ Twelfth-century laws recognise four royal roads: Watling Street, Ermine Street, the Fosse Way and the Icknield Way. However, these are all post-Conquest sources, and not secure evidence in establishing which routes were in use in the early medieval period.

The evidence for the use of particular roads in the early medieval period must be sought in OE charter boundary clauses, the place-names, the coin finds and the pottery finds; the coverage they provide is variable. The charter boundaries provide most of the written evidence, and can, if the boundary can be identified on the ground, pin-point accurately short stretches of roads of different degrees of importance (e.g. weg, sträet, herepath). Where a dense cluster of charters with bounds has survived a local road network can be suggested, but over most of England there are few charters, and so it is impossible to reconstruct a national network from them: they have not been considered here.

The place-name evidence has the great advantage of being countrywide, even if a little sparse in northern counties. It has the added advantage of describing many points of concern to the travellers along their routes, such as the nature of the road, the crossings and the facilities en route; the place-name evidence also helps to identify the rivers and seaways in use. The latter are more permanent features of a communications network than roads since they are naturally occurring, not man-made. As such they are always there to use: the rivers follow the same courses through the millenia (given minor variations due to deposition or erosion, and very occasional catastrophic changes of course), although they may need some maintenance. Roads, on the other hand, are made by man in whatever direction he needs to go at that period. A road can be abandoned and lost to use or a new one created, but a river is always there even if it is not used. New waterways (canals) can be created but only with great labour. In the absence of contemporary maps, the place-name evidence is of considerable importance.

The evidence from coin finds is useful but there are two major drawbacks: firstly, the finds are mostly southern and eastern; they give very little information about large areas of England in the west and north-west. Secondly, as find spots are not ordinarily precisely given, it is not known if the coins were found by the roadside and therefore likely to have been dropped by travellers or not (see p. 142); in contrast, the precise location of the named settlement is rarely a critical factor in assessing which routes are in use.

The evidence from pottery is less satisfactory. Firstly, and most importantly, the data are not easily available; secondly, as with coins, the western areas are less well covered; thirdly, pots were used in settlements regardless of their nearness or otherwise to routeways, and so

\footnotetext{
${ }^{1}$ Public Works, passim
} 
finds of sherds do not necessarily highlight routeways; fourthly, find spots are not necessarily a good indication of the distribution of pots in early medieval times, but rather where field walking and archaeological digs have taken place; and fifthly, a pottery only served a limited region. It would need the find-patterns of sherds of distinctive pottery types from many widely separated potteries to establish the routes that were used for the local distributions, which, in turn, would be needed in order to build up anything like a national routeway network. Pottery distributions are better at indicating the hinterland of the pottery and how that might impinge on the hinterlands of neighbouring potteries. However, the importance of waterways for carrying heavy, breakable goods is highlighted.

Although place-name evidence is good for establishing which routes were in use in early medieval times, it is much less useful in indicating at what times those routes were in use whether they were all in use throughout the period or whether some routes fell out of use or others came into use. Six or seven centuries is long enough for considerable changes to have taken place but the place-name evidence is very scarce in the first half of that time; most of it does not appear until near the end of the period in the mid-eleventh century. Nevertheless, there are strong hints that those place-names incorporating Latin portus and ora refer to landing places and routes that were in use in the earliest days of the Anglo-Saxon settlement. The evidence for this is that they were Latin borrowings; they frequently occur on the southeast coast, and two oras occur in association with the early royal sites at Sutton Hoo and Rendlesham. Elsewhere, its Anglian equivalent, ofer, is associated with other early, but short-lived, royal centres at Yeavering and Milfield, and/or with Bamburgh, pointing to an early-used route in Northumbria. The fact that so many of the routes in use were Roman, also suggests that they were in use in the early years of the Anglo-Saxon settlement, because, as described in chapter 10 , a route-way is most likely to continue as such if it has remained in continuous use since it was made. Other changes in nomenclature, such as the increasing use of $t \bar{u}$, point to the development of facilities along already established routes rather than the establishment of new routes. The latter are not entirely unknown as the change of name from Elintone to Maidenhead suggests that the Gough route from London to Bristol came into being (or into prominence) around the same time (see p. 80 ).

Since coins can be dated, coin finds can be used, when there are sufficient numbers of them, to give an idea of which routes were in use in what periods. There is insufficient evidence yet to be very precise about this (but see comments about M 810 and M 811 on pages 144 and 145); it would seem a promising approach for the future.

Pottery can also be dated, although not so exactly as coins, and might be of some use in establishing which routes were in use and when, but with all its other limitations this is not a very promising approach.

Having gone some way in establishing which routes were in use in the early medieval period and to a lesser extent at what time, is it possible to identify the raisons d'etre of such routes - who was using them and for what purposes? Again, with a time period of six or seven centuries conditions in England changed from the disruption of the migration period to the much more organised, settled rule of the tenth and eleventh centuries, and with this the demands put upon the roads and rivers also changed.

After the departure of the Romans, urban life broke down as did the buildings themselves, although the ruins were still an obvious feature of the landscape. The road system was no longer important for linking these sites nor for moving the Roman army and its supplies from place to place, although the indigenous Romano-British population could still be using it. Few Celtic names associated with routeways have survived; it was from the incoming Angles and Saxons and their descendants that the routeway nomenclature was derived. These incoming Angles and Saxons would have had different reasons for using these roads. Some of the earliest immigrants, having crossed the North Sea/ English Channel, would have made 
landfall and settled around the sheltered bays and estuaries. while others sailed up the eastflowing rivers to penetrate further inland: sooner or later the head of navigation would have been reached and they would have to have proceeded overland. Roads at this time were used as 'lines of penetration' by the incomers once they had gone beyond the heads of navigation

Gradually these settlers coalesced into larger groups, and small kingdoms emerged such as those of Kent, Sussex, Lindsey and East Anglia. In order to maintain their position their kings needed to bestow gifts of prestige objects or land on their followers. Some of the gifts would have originated overseas and would have been acquired by trading, and this could be one of the factors behind the growth of the emporia or wics such as Hamwic. Ipswich, London and York. They were well served by road and river routes, and accessible by sea from continental Europe. Hamwic developed with Wessex as its hinterland, Ipswich with East Anglia, York with Northumbria, and London (Aldwych) with Mercia and much of southern England. This meant that road and river routes to these places took on added importance; all four are close to roads and rivers that place-names indicate were in use in early medieval times (see pp. 138).

There were other goods that an ordinary medieval peasant community could not produce for itself; notable amongst these was salt. There were numerous coastal saltpans supplying the needs of nearby communities, but for those inland the source of supply was Droitwich or one of the Cheshire wiches. The traders plied the salt routes (which may have been in use as far back as Iron Age times) maintaining in use another set of roads. Iron was another commodity that sometimes needed transporting, because good quality iron ore deposits were not to be found everywhere; those in the Forest of Dean and the Weald have roads with indicative place-names serving them. Lead, needed for the vats in which the brine was boiled as well as for roofing, was probably obtained from Shropshire and the Peak District, and perhaps the Mendips, since these areas too are served by routes with indicative place-names along them. The need to exploit mineral resources brought into use a different set of routes from the 'lines of penetration' and those serving the emporia. They ensured that some Roman roads stayed in use, such as the M 14 in the Weald, which might otherwise have been abandoned and lost to invading woodland. The need to procure and distribute resources and man-made goods, what might be summarised as wealth creation and distribution, clearly plays a part in determining which routes are used; they must be those which make the mineral resources accessible or those which link the sheltered, coastal landing places to inland settlements or which serve major trading places.

A successful ruler should have a firm grip on the administration of his territory: for handing out justice, collecting taxes, organising defence and so on. To be able to do this effectively the administrative centre or centres are best situated at route centres. As kings were essentially itinerant in early medieval England they would have needed several 'administrative centres': there could have been considerable freedom of choice when selecting them. In Anglo-Saxon England a road system was already in existence by the time that any administrative centres were needed, and so places with good road links (and if possible river links) to the rest of the territory were desirable places. In other words, the preexisting road system might have had a considerable influence on the choice of site for the king's residences. In this case the royal residences would not be determining which preexisting Roman roads or ancient tracks are going to be used: the roads would be determining where the residences would be. This is quite the opposite to the routes which link up with the safe havens around the coast or to the mineral resources: in these cases there is no choice the roads which go to these places are the ones which have to be used. When Mercia was divided into shires in eleventh century, the burhs, now the county towns, around which the shires were formed, were chosen, at least partly, for their good communications by road and river (see pp. 138-9). Roads and rivers were used for many other purposes too; for moving 
timber, stone, grain, animals; by itinerant pedlars, smiths, pilgrims, churchmen and so forth Their needs, too, contributed to the communications network which had evolved by the end of the early medieval period. By the time of the Norman Conquest it was possible to travel the length and breadth of the kingdom with considerable speed - how else would King Harold in Yorkshire have heard of William of Normandy's landing so quickly, and have marched two hundred miles south in seven days?

The communications network, which the place-names indicate had evolved by the end of the eleventh century, is shown on the map in the end pocket of volume 2 . It shows, in addition, the stretches of road, which place-names evidenced after 1100 but generally before 1500 , indicate were in use; these are mostly in northern counties where there was no DB coverage, or they fill in the missing stretches of long routes further south. As they have been described in detail in chapter 9 , only more general comments are made here

The main impression is that a high proportion of Roman roads (south of York) were pressed into service by the end of the eleventh century, and that by 1500 (but often earlier), the missing links, such as those along M 15 and M 150 through the Weald and the Icknield Way between Royston and Dunstable, had indicative names along them giving the strong presumption that these stretches had always been in use but, as chance would have it, their indicative names had not been recorded by DB. Other apparently missing links occur around larger settlements, especially London, but also Gloucester, Lincoln, Hamwic and Baylham/Ipswich, where the name of the destination would have been the last link in the chain.

The Roman road system seems not to have served all needs. In particular, the ancient salt routes were a necessary addition to the network, as were extra routes leading west and northwest from London; the sector between M 4 to Silchester and M 1, Watling Street, was insufficiently served, and so the routes to Bristol (appearing on the Gough map), and to Oxford, Gloucester and Hereford (Gough map) arose, as well as sections of the Great North Road (Paris and Gough maps). Tracks over chalk downland were easy enough to establish and numerous stretches existed, particularly those near Winchester, an important centre. The densest network of routes is in central southern England, the Home Counties and the midlands - the heartlands of Wessex and Mercia.

Other areas were less well served: peninsulas surrounded on three sides by sea or estuaries lacked road links: examples are the Isle of Purbeck, Foulness, Walton on the Naze, Holderness, Amounderness and Fylde; several of them had landing places, so they were not entirely cut off. Other areas ill-served by roads were the Lake District because of its mountainous nature, and Lancashire because, with its extensive mosses and infertile sands, it was not a populous or desirable area. The routes linking the midlands to the northern counties ran through the Vale of York to Northumbria, both generally more fertile and populous areas than Lancashire and the Lake District. The Pennines, with long stretches of high moorland, was an area with few route-ways except for the trans-Pennine routes used by the Romans, enabling people from the east to reach the Eden valley and Carlisle, the Ribble estuary, and hence the communities around the Irish Sea.

The boulder clay lands of north Essex and west Suffolk, and parts of the Weald are not well served. In spite of them having been opened up by the Romans, the roads had apparently fallen into disuse. West of Exeter, where Roman roads hardly existed, there were no prominent well-paved routes to attract traffic, and so the old network of minor tracks persisted without any notable through routes being evident during the Anglo-Saxon period.

Place-names connected with water-borne traffic show that five main rivers were well used: the Trent, Great Ouse, Thames, Severn and Wye, along with some of their tributaries. In several instances, short stretches, usually tidal estuaries, of other smaller rivers were used to take shipping far enough inland to connect with the road system. Water transport was 
dominant in the marshes of the Fens and Somerset Levels. Coastal landing places were most frequent along the south and south-east coasts, implying trade across the English Channel and southern North Sea; however, north of the Wash there is little in the way of place-names to suggest North Sea trade; there was more activity in the Irish Sea and across the Bristol Channel to South Wales or Ireland.

There are hints that goods and people readily transferred from overland to water transport, and vice versa, in that some rivers appear to have been kept navigable sufficiently far upstream for travellers on the river to reach an important routeway. The effort of transshipping goods was compensated for by the greater economy and ease of transporting heavy or bulky goods by water.

Leges Henrici Primi of c.1113-1118 defined the 'viae regiae', the main roads, as those leading to civitate (probably including the -ceasters (Roman towns)), burgi (boroughs), castri (castles), markets and royal ports. The roads in use do link into many of these kinds of settlements. Sixty-six ceasters are listed in fig. 7.1. Ceaster was not invariably used of Roman towns, but fifty-seven of these did so: of these, thirty-five or thirty-six were by roadsin-use, and twenty or twenty-one by roads without indicative place-names. The latter group includes ten in CMB, WML, NTB and DUR, some, in high and remote areas which were unlikely to have any urban function in early medieval times, would not necessarily expect to have any main road connections. It was rare further south for any ceaster referring to a Roman town not to be on a road-in-use.

The emporia of the eighth century were busy markets. They had good road access in theory, but in several cases place-name evidence for the road being in use is absent for the last few miles. This may be because the name of the emporium itself may be the last on the list of places to go through memorised by the traveller: it does not necessarily mean that those last few miles of road were not in use. This is clearly the case with Hamwic and some approaches to Aldwych (London), and one to Norwich. Ipswich is not so inaccessible by road as it looks, the Roman road from Baylham via Ipswich and Stratton Hall to Walton Castle existed (see p. 112) There is ready access to Fordwich KNT, and York (Eoforwic).

Productive sites, which were likely to be sites of markets and fairs, were discussed on pages 145-6, where it was noted that most of them were accessible by one or more roads and sometimes by water too.

Burg is a term that means 'fortified place' but the fortified place could be an early hill fort, a Roman town or station, a military stronghold used by the Anglo-Saxons, a fortified manor house or even a monastery. ${ }^{2}$ There are four instances (Aldborough, Brough WML,

Littleborough and Canterbury) where burg refers to a Roman site and is served by one or more roads-in-use, and four instances (Brough DBY, NTT, YOE, and Burgh CMB) where it is not served by a road-in-use: Burgh castle SFK, is on the coast. Only four of the Burghal Hidage towns are called '-burg': Malmesbury WLT, Burpham SSX and Chisbury WLT are not on roads in use: Shaftesbury DOR, is on a Gough road-in-use.

The Lindsey burhs, sites defending this early kingdom from invasion, described by $\mathrm{Cox}^{3}$ were all by Roman roads or old tracks which were likely to have been in use at the time, but the place-names only pick out about half of these routes. Perhaps both burhs and roads had declined in importance after the seventh century when Lindsey ceased to be a separate kingdom (see p. 138).

Because the meaning of place-name elements was so well defined, and so consistently applied, from Northumbria to Kent and Devon, it was possible for a corpus of names to develop along routeways whose meanings and implications were understood by all travellers,

\footnotetext{
${ }^{2}$ Parsons and Styles, Vocabulary: Brace-Ceaster, pp. 74-85

${ }^{3}$ Barrie Cox, burh in Lindsey, pp. 35-56.
} 
and which were of considerable use to them. As the way in which these terms were used becomes better understood today, so it becomes possible to trace the routes most frequented by the long-distance, early medieval travellers. Further study may suggest other place-names linked to routeways and other desirable destinations but it is clear that the great gap in knowledge about the routeway network which was in use between the departure of the Romans and the drawing of the first maps can be substantially, though not fully, filled by place-name evidence. 


\section{BIBLIOGRAPHY}

For county and national dictionaries of place-names see also under abbreviations Printed Primary Sources

The Anglo-Saxon Chronicles, trans. and ed. Michael Swanton (London, 2001)

Bede, The Venerable, Venerabilis Baedae Historiam ecclesiasticum gentis Anglorum, ed. Charles Plummer (Oxford, 1896).

Bede, The Venerable, The Ecclesiastical History of the English People, trans. J. McClure and Roger Collins (Oxford, 1994).

Book of Fees, 1, 1198-1242 (also called Testa de Nevill) (HMSO, London, 1920).

Bridgwater Borough Archives 1200-1377, ed., Thomas Bruce Dilks (Somerset Record Society, 48, 1933).

Calendar of the Manuscripts of the Dean and Chapter of Wells, 1 (Historical Manuscripts Commission, 1907).

Calendar of the Manuscripts of the Dean and Chapter of Wells, II (Historical Manuscripts Commission, 1914)

Cartulary of the Abbey of Eynsham, ed., H.E.Salter ( 2 vols., Oxford Historical Society, 49, 1907; 51, 1908).

Cartulary of Buckland Priory, ed., F.W. Weaver (Somerset Record Society, 25, 1909).

Cartulary of Creake Abbey, ed., A.L. Bedingfield (Norfolk Record Society, 35, 1966).

Charters of Norwich Cathedral Priory 1 and 2, ed., Barbara Dodwell (Pipe Roll Society, 40, $1974 ; 46,1985)$.

Chartulary of Rievaulx, ed., J.C. Atkinson (Surtees Society, 83, 1887).

Chronica Monasteria de Melsa, 3, ed., Edward A. Bond (Rolls Series, London, 1868).

Dugdale, William, A History of Imbanking and Draining of divers Fenns and Marshes, revised C.N.Cole, $\left(2^{\text {nd }}\right.$ ed. London, 1772).

Faden's Map of Norfolk, introduction by J.C.Barringer (Norfolk Record Society, 42, 1973). Feet of Fines for the County of Somerset, 1106-1307, ed., Emanuel Green (Somerset Record Society, 6, 1892).

Feet of Fines for the County of Somerset, Henry IV - Henry VI, ed., Emanuel Green

(Somerset Record Society, 22, 1906).

Gesta Abbatum Monasterii Sancti Albani 1, ed., Henry Thomas Riley (3 vols., Rolls Series 28. $4 \mathrm{a}, 1867)$.

The Great Chartulary of Glastonbury, ed., Dom Aelred Watkin (Somerset Record Society, $63,1952)$. 
The Honour of IJunster, ed., H.C. Maxwell Lyte (Somerset Record Society, 33, 1918).

Newminster (artulary, 1, ed., J.T. Fowler (Surtees Society, 66, 1878).

Ogilby, John, Ogilby's Road Maps of England and Wales from ()gllhy's 'Brilummu' 16-5. ed., Roger Cleeve (Reading, 1971).

Public Works in Medieval Law I and 2, ed., C. T. Flower (Selden Society, 32, 1915; 40, 1923).

Report on the Manuscripts of Wells Cathedral (Historical Manuscripts Commission, 1885)

Two Cartularies of the Benedictine Abbeys of Muchelney and Athelney, ed., E.H. Bates (Somerset Record Society, 14, 1899).

Waghenaer, Lucas, Jansz, Spieghel der Zeevaerdt, (Leyden, 1584-5), reprint with introduction by R.A. Skelton (Amsterdam, 1964).

\section{Printed Secondary Works}

Addison, William, The Old Roads of England (London, 1980).

Alexander, J.S., 'Building Stone from the East Midland Quarries: Sources, Transport and Usage', Medieval Archaeology, 39 (1995), pp. 107-35.

Allinson, K.J., Beresford, M.W. and Hurst, J.G., The Deserted Villages of Oxfordshire (Department of Local History Occasional Papers 17, Leicester, 1966).

Anderton, Mike (ed.), Anglo-Saxon Trading Centres: Beyond the Emporia (Glasgow, 1999). Arkell, W.J., Oxford Stone (London, 1947).

Atkin, M.A., 'Places named 'Anstey': a Gazetteer', JEPNS, 30 (1998), 83-98.

Atkin, M.A., 'Hollin Place-Names in North-West England', Nomina, 12 (1988-9), pp. 77-88.

Auduoy, Michel and Chapman, Andy, Raunds: the origin and growth of a midland village, $A D$ 450-1500 (Oxford, 2009).

Bagshawe, R.W., Roman Roads (Shire Publications 10, Princes Risborough, 1979, reprinted 1990).

Bailey, Keith, 'Place-Names in -cot: The Buckinghamshire Evidence', JEPNS, 31 (1999), pp. 77-90.

Bassett, Steven (ed.), The Origins of the Anglo-Saxon Kingdoms (Leicester, 1989).

Bell, Tyler, The Religious Reuse of Roman Structures in Early Medieval England, BAR British Series, 390 (Oxford, 2005).

Berridge, N.G., and Pattison, J., Geology of the Country around Grimsby and Partington (HMSO, London, 1994).

Berry, Bernard, A Lost Roman Road (London, 1963).

Blair, John, Anglo-Saxon Oxfordshire (Stroud, 1994). 
Blair, John (ed.), Waterways and ('anal-bulding in Mederal Fingland (Oxford. 2007)

Bond, James, 'Canal Construction in Medieval England' in Blair 'H alerwats' (2007). 153 206.

Bradley, Richard, 'The South Oxfordshire Grim's Ditch and its Significance', ()xomensiu, 33 (1968), 1-13.

Brookfield, H.C., 'The Estuary of the Adur', Sussex Archaeological ('ollections, 90 (1952), 153-63.

Brooks, Nicholas, Communities and Warfare 700-1 400 (London, 2000).

Cameron, Kenneth, A Dictionary of Lincolnshire Place-Names (EPNS, Nottingham, 1998).

Campbell, James (ed.), The Anglo-Saxons (London, 1982).

Channel Pilot, vol. I, (Admiralty Hydrographic Department, London, 1957).

Carroll, Jayne and Parsons, David N., Anglo-Saxon Mint Names I, Axbridge … Hythe (EPNS, Nottingham, 2007).

Casson, Lionel, Travel in the Ancient World (London, 1979).

Clarke, A., 'A Roman Road on the Eastern Fringe of the New Forest from Shorn Hill to Lepe', Proceedings of the Hampshire Field Club and Archaeological Society, 58 (2003), 33-58.

Cleere, Henry and Crossley, David, The Iron Industry of the Weald (Leicester, 1985).

Coates, Richard, 'Methodological Reflections on Leatherhead', JEPNS, 12 (1980), 70-4.

Coates, Richard, 'Coldharbour for the Last Time?', Nomina, 8 (1984), 73-78.

Coates, Richard, The Place-Names of Hampshire (London, 1989).

Coburn, A., Dudley, E., and Spence, Robin, Gypsum Plaster: its Manufacture and Use (London, 1989).

Cochrane, C., The Lost Roads of Wessex (2nd ed. London, 1972).

Cole, Ann, 'Topography, Hydrology and Place-Names in the Chalklands of Southern England: Funta, $\bar{E}$ wiell and Ëwielm', Nomina, 9 (1985), 3-19.

Cole, Ann, 'Distribution and Use of the OE Place-Name Element Cealc', JEPNS, 19 (1988), 45-55.

Cole, Ann, 'The Meaning of the OE Place-Name Element Ōra', JEPNS, 21 (1989), 15-22.

Cole, Ann, 'The Origin, Distribution and Use of the Place-Name Element Ōra and its Relationship to the Element Ofer', JEPNS, 22 (1990), 26-41.

Cole, Ann, 'The Distribution and Use of the OE Place-Name Mere-tün', JEPNS, 24 (1992), 30-41.

Cole, Ann, 'The Distribution and Use of Mere as a Generic in Place-Names', JEPNS, 25 (1993), 38-50. 
Cole, Ann, 'The Anglo-Saxon Traveller', Nomina, 17 (1994), 7-18.

Cole, Ann, 'The Use of Netel in Place-Names', JKPNS, 35 (2003), 49-58

Cole, Ann, 'The Use of ON Nata in Place-Names', JEPNS; 36 (2004), 51 -3.

Coles, Bryony, 'Trisantona Rivers: a landscape approach to the interpretation of river names', Oxford Journal of Archaeology, 13 (1994), 295-311.

Cook, Martin, Medieval Bridges (Shire Publications 77, Princes Risborough, 1998).

Cooper, Alan, 'The Rise and Fall of the Anglo-Saxon Law of the Highway', The Haskins Society Journal, 12 (2002), 39-69.

Cox, Barrie, 'The Significance of the Distribution of the English Place-Names in häm in the Midlands and East Anglia', JEPNS, 5 (1973), 15-73.

Cox, Barrie, 'Place-Names of the Earliest English Records', JEPNS, 8 (1976), 12-66.

Cox, Barrie, 'The Pattern of Old English Burh in Early Lindsey', Anglo-Saxon England, 23 (1994), pp. 35-56.

Cox, Barrie, A Dictionary of Leicestershire and Rutland Place-Names (EPNS, Nottingham, 2005).

Cracknell, Basil E., "Outrageous Waves": Global Warming and Coastal Change in Britain (Chichester, 2005).

Crawford, O.G.S., 'Cerdic and the Cloven Way', Antiquity, 5 (1931), 441-58.

Crawford, O.G.S., Archaeology in the Field (London, 1953).

Crump, W.B., 'Saltways from the Cheshire Wiches', Transactions of the Lancashire and Cheshire Antiquarian Society, 54 (1940), 84-142.

Cunliffe, Barry, Wessex to A.D. 1000 (London, 1993).

Cunliffe, Barry, Facing the Ocean (Oxford, 2001).

Darby, H.C., Medieval Fenland (Newton Abbot, 1974).

Darby, H.C. and Campbell, E.M.J., The Domesday Geography of South-East England (Cambridge, 1962).

Darby, H.C. and Maxwell, I.S., The Domesday Geography of Northern England (Cambridge, 1962).

Darby, H.C. and Terrett, L.B., The Domesday Geography of Midland England (Cambridge, 1954).

Davies, Hugh, Roads in Roman Britain (Stroud, 2002).

Davis, R.H.C., 'The Ford, The River and The City', Oxoniensia, 38 (1973), 258-67.

Defoe, Daniel, A Tour through England and Wales (originally published 1724-6, Everyman's Library edition, London, 1948). 
Dodd, A.E., and E.M., Peakland Roads and Trackways (Ashbourne. 1980),

Dyer, Christopher, 'Towns and Cottages in Eleventh Century. England', in Henry MayrHarting and R.I. Moore (eds.), Studies in Medieval History Presented to R.H.( . I aw:s (London, 1985), 91-106.

Dyer, Christopher, Hanbury: Settlement and Society in a Woodland Landscape (Leicester, 1991).

Dymond, D.P., 'Roman Bridges on Dere Street, County Durham', Archaeological Journal, 118 (1963), 136-64.

Dymond, David, 'A Misplaced Domesday Vill: Otringhithe and Bromehill', Norfolk Archaeology, 43 (1998), 161-8.

Eardley-Wilmot, Hazel, Yesterday's Exmoor (Exeter, 1990).

Eardley-Wilmot, Hazel, The Overland Way (Tiverton, 1995).

Edmonds, Fiona, 'Barrier or Unifying Feature? Defining the Nature of Early Medieval Water Transport in the North-West' in Blair, Waterways (2007), 21-36.

Edwards, J., and Hindle,B., 'The Transportation System of Medieval England and Wales', Journal of Historical Geography, 17(2) (1991), 123-34.

Edwards, J., and Hindle, B., 'Comment: Inland Water Transportation in Medieval England', Journal of Historical Geography 19(1) (1993), 12-4.

Edwards, K.C., The Peak District (London, 1962).

Edwards, L.A., Inland Waterways of Great Britain (sixth ed. St Ives, 1985). See also seventh edition by Jane Cumberlidge and L.A. Edwards (St Ives, 1998).

Edwards, R.A., The Minehead District: A Concise Account of the Geology (HMSO, London, 1999).

Ekwall, Eilert, English River Names (Oxford, 1928).

Ekwall, Eilert, 'The English Place-Names Drayton, Draycot, Drax etc.', Namn och Bygd, 20 (1932), 46-70.

Elmhirst, L.K., 'Some Aspects of the History of Dartington Hall', Transactions of the Devonshire Association, 91 (1959), 19-35.

Everitt, Alan, Contiuity and Colonisation: the evolution of Kentish settlement (Leicester, 1986).

Fellows-Jensen, Gillian, Scandinavian Settlement Names in Yorkshire (Copenhagen, 1972).

Fenwick, Valerie, (ed.) The Graveney Boat: a Tenth Century Find from Kent, BAR British

Series 53 (Oxford, 1978).

Finberg, H.P.R., The Early Charters of Wessex (Leicester, 1964). 
Finch-Smith, Roger, Roadside Settlements in Lowland Roman Brıtun (BAR British Series 157, Oxford, 1987).

Fitzpatrick, A.P. and Scott, P.R., 'The Roman Bridge at Piercebridge, North YorkshireCounty Durham', Britannia, 30 (1999), 111-132

Fox, Cyril, 'Sleds, Carts and Waggons', Antiquity, 5 (1931), 185-199

Gaunt, G.D., 'The Artificial Nature of the River Don north of Thorne, Yorkshire', Yorkshire Archaeological Journal, 47 (1975), 15-21.

Gaunt, G.D., Geology of the Country around (joole, Doncaster and the Isle of Axholme (HMSO, London, 1994).

Gelling, Margaret, 'English Place-Names derived from the Compound Wīchām', Medieval Archaeology, 11 (1967), 87-104.

Gelling, Margaret, Place-names in the Landscape (London, 1984).

Gelling, Margaret, Signposts to the Past (1978; reprint Chichester, 1997).

Gelling, Margaret, The West Midlands in the Early Middle Ages (Leicester, 1992).

Gelling, Margaret, The Landscape of Beowulf', Anglo-Saxon England, 31 (2002).

Gelling, Margaret and Cole, Ann, The Landscape of Place-Names (Stamford, 2000; reprint Donington, 2003).

Goudie, Andrew, The Nature of the Environment (Oxford,1984).

Gough, H., The Itinerary of King Edward I (2 vols. Paisley, 1900).

Gover, J.E.B., The Place-Names of Hampshire (unpublished typescript: a copy is held at EPNS, Nottingham, c. 1961).

Grundy, G.B., 'The Ancient Highways and Tracks of Wiltshire, Berkshire and Hampshire', Archaeological Journal, 75 (1918), 69-194.

Grundy, G.B., 'The Saxon Land Charters of Wiltshire', Archaeological Journal, 77 (1920), 8-126.

Grundy, G.B., 'The Saxon Land Charters of Hampshire', Archaeological Journal, 78 (1921), $55-173 ; 81$ (1924), 31-126; 83 (1926), 91-253.

Grundy, G.B., 'Saxon Charters of Worcestershire', Transactions of the Birmingham Archaeological Society, 52 (1930), 1-183; 53 (1931), 18-131.

Grundy, G.B., 'The Ancient Highways and Tracks of Worcestershire and the Severn Basin' Archaeological Journal, 91 (1934).

Grundy, G.B., Saxon Charters and Field Names of Gloucestershire (Bristol, 1935).

Grundy, G.B., Saxon Charters and Field Names of Somerset (Somerset Archaeological and Natural History Society publication, 1935). 
Grundy, G.B., 'The Ancient Highways of Somerset', Archueologrcal Iournal, 96 (1939), 226-97

Grundy, G.B., 'The Ancient Highways of Devon', Archaeologicul Journul, 98 (1941), 131 164.

Hall, David, The Fenland Project, Number 10. ('ambridgeshire Survev, Isle of Lily and Wisbech, East Anglian Archaeology, 79 (Cambridge, 1996).

Hamerow, Helena, Excavations at Mucking, vol. 2: the Anglo-Saxon settlement (English Heritage, London, 1993).

Hammond, Madelaine, 'The Anglo-Saxon Estate of Readanora and the Manor of Pyrton, Oxfordshire', Oxoniensia, 63 (1998), 23-42.

Harrison, David, The Bridges of Medieval England: Transport and Society 400-1800) (Oxford, 2004).

Harrison, Sarah, 'The Icknield Way: Some Queries', Archaeological Journal, 160 (2003), 122.

Harvey, P.D.A., Medieval Maps (London, 1991).

Haslam, Jeremy, 'The Development and Topography of Anglo-Saxon Cambridge', Proceedings of the Cambridge Antiquarian Society, 72 (1984), pp. 13-39.

Hayes, Raymond H., Old Roads and Pannier Ways in North-East Yorkshire (Helmsley, 1988).

Hepple, Leslie and Doggett, Alison, The Chilterns (Chichester,1992).

Higham, Mary, 'The Problem of the Bee-keepers', JEPNS, 34 (2002), 23-8.

Hill, David, An Atlas of Anglo-Saxon England (Oxford, 1987).

Hindle, B.P. (B.), 'The Road Network of Medieval England and Wales', Journal of Historical Geography, 2 (3) (1976), 207-21.

Hindle, B.P., 'Seasonal Variations in Travel in Medieval England', Journal of Transport History, 4 (3) (Feb. 1978), 170-8.

Hindle, B. P. (Brian Paul), Maps for Local History (London, 1988).

Hindle, B. P. (Paul), Roads and Tracks for Historians (Chichester, 2001).

Hindle, B. P. (Brian Paul), Medieval Roads (Shire Publications 26, Princes Risborough, 2002).

Holden, E.W., 'New Evidence Relating to Bramber Bridge', Sussex Archaeological Collections, 113 (1975), 104-117. 
Hollinrake, Charles and Nancy, 'The Abbey Enclosure Ditch and a late Saxon Canal: Rescue Excavations at Glastonbury 1984-88', Somerset Archaenological and Natural Hisurn. Society, 136 (1992), 73-94

Hooke, Della, 'The Droitwich Salt Industry', in Anglo-Saxon Studies in Archueologi and History 2, ed. David Brown, James Campbell and Sonia Chadwick Hawkes (BAR British Series, 92, Oxford, 1981), 123-69.

Hooke, Della, The Anglo-Saxon Landscape: the Kingdom of the Hwicce (Manchester, 1985)

Hooke, Della, 'Anglo-Saxon Estates in the Vale of the White Horse', Oxoniensia, 52 (1987), 129-43.

Hooke, Della, Pre-Conquest Charter Bounds of Devon and Cornwall (Woodbridge, 1994).

Hooke, Della, The Landscape of Anglo-Saxon England (Leicester, 1998).

Hooke, Della, 'Uses of Waterways in Anglo-Saxon England', in Blair, Waterways (2007), pp. 37-54

Hope-Taylor, Brian, Yeavering (HMSO, London, 1977).

Horovitz, David, The Place-names of Staffordshire (Brewood, Stafford, 2005).

Hoskins, W.G., Provincial England (London, 1963).

Hough, Carole, 'OE *grceg in Place-Names', Neuphilologische Mittelungen 4, 96, (1995), 361-5.

Hough, Carole, 'Commonplace Place-Names', Nomina, 30 (2007), pp. 101-20.

Houghton, A.W.J., 'The Roman Road from Greensforge through Central Welsh March', Transactions of the Shropshire Archaeological Society, 56 (1961), 233-243.

Houghton, A.W.J., 'A Roman Road from Ashton, North Herefordshire to Marshbrook, Salop', Transactions of the Shropshire Archaeological Society, 57 (1966), 185-90.

Houghton, F.T.S., 'Salt-ways', Transactions of the Birmingham Archaeological Society, 54 (1932), 1-17.

Jermy, Kenneth E., 'Longford and Langford as Significant Names in Establishing Lines of Roman Roads', Britannia, 23 (1992), 228.

Jervoise, E., Ancient Bridges of the South of England (London, 1930).

Jervoise, E., Ancient Bridges of Mid and Eastern England (London, 1932).

Jones, E., 'River Navigation in Medieval England', Journal of Historical Geography, 26 (2000), 60-75.

Jones, Richard, and Page, Mark, Medieval Villages in an English Landscape (Macclesfield, 2006).

Kellaway, G.A., and Welch, F.B.A., Geology of The Bristol District (HMSO, London, 1993). 
Kilmurry, Kathy, The Pottery Industry of Stamford, Lincs. c. A.I). 45()-1250, BAR, British Series 84 (Oxford, 1980)

Kitson, Peter (unpublished) Guide to Anglo-Saxon (harter Boundartes.

Laflin, Susan, 'Roman Roads and Ford Place-Names in Shropshire', Shropshire History' and Archaeology, 76 (2001), 1-10.

Langdon, J., 'Inland Water Transport in Medieval England', Journal of Historical

Geography, 19 (1) (1993), 1-11.

Langdon, John, Horses, Oxen and Technological Innovation (Cambridge, 1986).

Langdon, John, 'The Efficiency of Inland Water Transport in Medieval England', in Blair, 'Waterways' (2007), 110-30.

Lapidge, Michael; Blair, John; Keynes, Simon; Scragg, Donald, ed., The Blackwell Encyclopaedia of Anglo-Saxon England (Oxford, 2001).

Latham, R.E., Dictionary of Medieval Latin from British Sources, fascicle 8 (British Academy, London, 2003).

Leighton, A.C., Transport and Communication in Early Medieval Europe 500-1100 A.D.

(Newton Abbot, 1972).

Leslie, Kim and Short, Brian, (eds.), An Historical Atlas of Sussex (Chichester, 1999).

Lewis, C.P. 'Welsh Territories and Welsh Identities in Anglo-Saxon England' in Britons in Anglo-Saxon England, ed. N.J. Higham (Woodbridge, 2007), pp. 130-43.

Lobel, M.D., The Atlas of Historic Towns, 2 (London, 1975).

Maddicott, John, 'Trade, Industry and the Wealth of King Alfred', Past and Present, 123 (1989), 3-51.

Maddicott, John, 'Debate: Trade, Industry and the Wealth of King Alfred', Past and Present, 135 (May, 1992).

Maddicott, John (J.R.), 'London and Droitwich c. 650-750: trade, industry and the rise of Mercia', Anglo-Saxon England, 34 (2005), pp. 7-58.

Malpas, F.J., 'Roman Roads South and East of Dorchester-on-Thames', Oxoniensia, 52 (1987), 26-33.

Margary, Ivan D., Roman Ways in the Weald (London, 1948).

Margary, Ivan D., Roman Roads in Britain (2 vols. London, 1955, 1957). See also $3^{\text {rd }}$ edn., 1973.

Maynard, Helen, 'The Use of the Place-Name elements Mör and Mersc in the Avon Valley', Transactions of the Birmingham and Warwickshire Archaeological Society, 86 (1974), 80-4 
Mellor, Maureen, 'A Synthesis of Middle and Late Saxon, Medieval and Early Post-medieval Pottery in the Oxford Region', Oxoniensia, 59 (1994), 17-217.

Millea, Nick, The Gough Map (Oxford, 2007).

Mills, David, The Place-Names of the Isle of Wight (Stamford, 1996)

Morris, C., Hargreaves, G. and Parker, R.P.F., 'The Lower Icknield Way,' ()xonicnsia, 33 (1968), 14-21.

Morris, G.E., 'The Significance of the Name Stonegrave', JEPNS, 17 (1985), 14-9.

Morris, John, general editor, Domesday Book, vol. 30, Yorkshire; vol. 31, Lincolnshire; vol. 34, Suffolk (Phillimore, Chichester, 1986).

Muir, Richard, The Lost Villages of Britain (London, 1982).

Muir, Richard, The New Reading the Landscape (Exeter, 2000).

Newberry, Ken, The River Lavant (Chichester, 1987).

Newton, Robert, The Making of the Northumberland Landscape (London, 1972).

Ogden, T.R., "“Coldharbours" and Roman Roads', Durham University Journal, 59 (1967), 13-24.

Ohler, Norbert, The Medieval Traveller (English translation Caroline Hillier,Woodbridge, 1989).

Old, R.A., Hamblin, R.J.O., Ambrose, K. and Warrington, G., Geology of the Country around Redditch (HMSO, London, 1991).

Osborne White, H.J., A Short Account of the Geology of the Isle of Wight (HMSO, London, 1921).

Owen, A.E.B., 'Roads and Romans in South-East Lindsey: the Place-Name Evidence', in Alex R. Rumble, (ed.), Names, Places and People (Stamford, 1997), 254-268.

Owen, Arthur, and Coates, Richard, 'Traiectus/Tric/Skegness: a Domesday Name Explained', Lincolnshire History and Archaeology, 38 (2003), 42-4.

Palliser, D.M., Cambridge Urban History Vol.1, 600-1540 (Cambridge, 2000).

Parsons, David, and Styles, Tanya (eds.), The Vocabulary of English Place-Names: A-Box (Nottingham, 1997).

Parsons, David, and Styles, Tanya (eds.), The Vocabulary of English Place-Names: BraceCeaster (Nottingham, 2000).

Perkins, John W., Geology Explained: Dartmoor and the Tamar Valley (Newton Abbot, 1972).

Pestell, Tim and Ulmschneider (ed.), Markets in Early Medieval Europe: Trading and Productive Sites 650-850 (Macclesfield, 2003). 
Pevsner, N. and others, Buildings of Englund, (Pevsner Architectural Guides. London)

Pickles, Thomas, 'Biscopes-tün, Munecu-tün and Preostu-tīn. dating, significance and distribution', in The C'hurch in English Place-Names, ed. Eleanor Quinton (EPNS. Nottingham, 2009), pp. 39-107.

Phillips, C.W., 'A Roman Ferry across the Wash', Antiquity, 6 (1932), 342-8.

Pile, John, 'Ora Place-Names in the Portsmouth Area', Humpshire Field ('lub and Archaeological Society Newsletter, 33 (Spring 2000), 3-7.

Raistrick, Arthur, Green Roads in the Mid-Pennines (Ashbourne, 1991).

Reed, Michael, The Buckinghamshire Landscape (London, 1979).

Rhodes, Ed., 'Identifying Human Modifications of River Channels', in Blair, 'Waterways' (2007), 133-52.

Richardson, W.A.R., 'The Owers, Les Ours, Weembrug and 'the OId City': Place-Names, History and Submarine Archaeology' JEPNS, 33 (2001), 55-114.

Rippon, Stephen, The Severn Estuary (London, 1997).

Rolt, L.T.C., Navigable Waterways (London, 1969).

Rumble, Alex, 'A Bedan Gloss on Bedfont, Bedwell etc.', Nomina, 12 (1988-9), 123-30.

Samson, Ross, 'Illusory Emporia and Mad Economic Theories' in Mike Anderton (ed.) (Glasgow, 1999), 76-90.

Sawyer, P.H., (ed.), Anglo-Saxon Charters: an Annotated List and Bibliography (London, 1968).

Scarfe, Norman, The Suffolk Landscape (London, 1972).

Scarfe, Norman, Suffolk in the Middle Ages (Woodbridge, 1986).

Shephard-Thorn, E.R., Smart, J.G.O., Bisson, G., and Edmonds, E.A., Geology of the Country around Tenterden (HMSO, London, 1966).

Sherratt, Andrew, 'Why Wessex? The Avon Route and River Transport in Later British PreHistory', Oxford Journal of Archaeology, 15 (1996), 211-234.

Slater, T.R., 'Controlling the South Hams: The Anglo-Saxon Burh at Halwell', Reports and Transactions of the Devonshire Association, 123 (1991), 57-78.

Smart, J.G.O., Bisson, G., and Worssam, B.C., Geology of the Country around Canterbury and Folkestone (HMSO, London, 1966).

Smith, A.H., English Place-Name Elements (2 vols., EPNS, Cambridge, 1956).

Soil Map of England and Wales (at a scale of 1:250,000 in 6 sheets), (published by the Ordnance Survey, Southampton, 1983). Includes a booklet 'Legend for the 1:250,000 Soil Map of England and Wales'. 
Steane, John, The Northampton Landscape (London, 1974).

Steers, J.A., The (oastline of England and Wales (Cambridge, $2^{\text {nd }}$ edition 1969)

Stenton, F.M., 'The Road System of Medieval England', Liconomic History' Revie'w, 7 (1936), 1-21.

Stenton, Frank, Anglo-Saxon England (Oxford, $3^{\text {rd }}$ edition 1971).

Stevenson, W.H. and Salter, H.E., The Early History of St John's (ollege (Oxford Historical Society n.s. vol. 1, 1939).

Sylvester, R.J. and Andrew Rogerson, Fenland Project No. 3: Norfolk Survey, Marshland and Nar Valley (East Anglian Archaeology 45, Dereham, 1988).

Symonds, Leigh Andrea, Landscape and Social Practice: the Production and Consumption of Pottery in $10^{\text {th }}$ Century Lincolnshire, BAR, British Series 345 (Oxford, 2003).

Tallon, Philip, 'What was a Caldecote?', JEPNS, 31 (1999), 31-54.

Taplin, Kim, 'Beyond the Limit' The Countryman, 97, no.5 (1992), 65-70.

Taylor, Christopher, Dorset (London, 1970).

Taylor, Christopher, Roads and Tracks of Britain (London, 1979).

Thacker, Fred, S., The Thames Highway 2: Locks and Weirs (reprint Newton Abbot, 1968).

Timperley, H.W, and Brill, E., Ancient Trackways of Wessex (London, 1965).

Toller, T. Northcote, (ed.), An Anglo-Saxon Dictionary (Oxford, 1898).

Toms, H.S., 'Ancient Ponds near Cissbury', Sussex County Magazine, vol. 1 (Aug 1927).

Toms, H.S., 'Ancient Ponds near Patcham', Sussex County Magazine, vol. 8 (Aug. 1934).

Toms, H.S., 'Ancient ponds near Falmer', Sussex County Magazine, Vol. 8 (Sept. 1934).

Toms, H.S., 'Some Sussex Meres', Sussex County Magazine, vol. 8

(Nov. 1934),

Tooley, R.V., Maps and Map-Makers (London, $6^{\text {th }}$ ed., 1978).

Torvell, David, "The Significance of 'Hereford", JEPNS, 24 (1992), 42-8.

Toulson, Shirley, The Drovers (Shire Publications 45, Princes Risborough, $2^{\text {nd }}$ ed. 1988).

Viatores, The, Roman Roads in the South-East Midlands (London, 1964).

VCH Cambridgeshire 7 (London, 1978).

VCH Shropshire 8 (London, 1968).

VCH Oxfordshire 8 (London, 1964).

VCH Warwickshire 3 (London, 1945).

VCH Worcestershire 4 ( London, 1924).

Wade-Martins, Peter, (ed.), An Historical Atlas of Norfolk (Norwich, 1994). 
Ward, E.M., 'The Evolution of the Hastings Coastline', (jeographical Journal, 56 (1920). $107-123$.

Watts, Martin, Working Oxen (Princes Risborough, 1999).

Watts, Victor, A Dictionary of County Durham Place-Numes (EPNS, Nottingham, 2002).

Watkins, Alfred, The Old Straight Track (reprint London, 1974).

Webster, Graham, The Cornovii (London, 1975).

West, Stanley, A Corpus of Anglo-Saxon Material from Suffolk (East Anglian Archaeology, 84, Ipswich, 1998). 